\title{
AN INTRODUCTION TO
}

AGRICULTURE

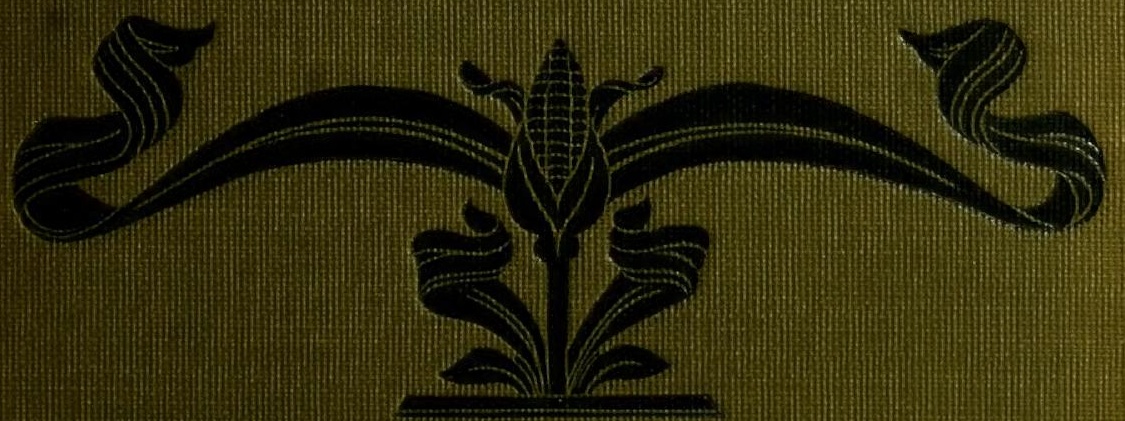

A.A. UPHAM 


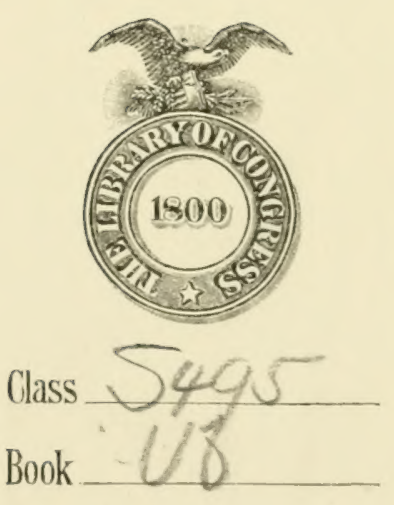

Copyrightt №.

COPYRIGIT DEPOSIT. 

AN INTRODUCTION TO
AGRICULTURE 



\title{
AN INTRODUCTION
}

TO

\section{AGRICULTURE}

BY

\author{
A. A. UPHA M
}

TEACHER OF SCIENCE, STATE NORMAL SCHOOL

WHITEW ATER, WISCONSIN

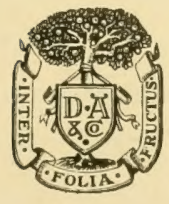

NEW YORK

D. APPLETON AND COMPANY

1910 


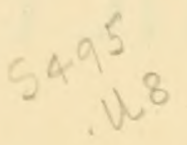

Copyright, 1910, By

D. APPLETON AND COMPANY

C Cl.A261091 


\section{PREFA C E}

THE author's thought in preparing this book has been to provide an elementary text on agriculture suitable for use by children of the seventh and eighth grades, and by pupils of a corresponding advancement in ungraded schools. It is hoped, also, that the book will not be found unsuited to the needs of Reading Circles and of individual students.

The author, of course, makes no claim to completeness, nor is the book offered as a guide to farming. The effort has been, however, to touch those matters which would be most useful to pupils in our rural schools, and especially to give the underlying theory for many farm processes and practices.

It is believed that teachers and students will find the summaries and questions at the end of each chapter especially helpful in reviewing and making definite the information which the chapters contain. One of the most important reasons for teaching agriculture in schools is to prepare pupils to read and understand 
agricultural literature. Lists of such literature and directions for obtaining it will be found at the end of the book.

Acknowledgment is gratefully made for the use of material found in various Farmers' Bulletins and reports, especially those of the United States Department of Agriculture, and of the State Experiment Stations of Wisconsin, Vermont, and Minnesota. The author is also grateful to those whose names appear in connection with various illustrations for the use of the same.

A. А. Uрнам.

Whitewater, Wis., 1910. 


\section{O N T E N T S}

CHAPTER

* I. The Nature of Plants . . . . . 1-9

The Science of Agriculture, 1; The Parts of a Plant, 2; How a Plant Grows, 4; How the Plant Gets Its Food, 5; Conditions of Growth, 7; Plant Food Must Be Usable, 8; Summary, 9; Questions, 9.

II. The șon,

The Composition of Soil, 10; Kinds of Soil, 11; Formation of soil-Rock Weathering, 13; (ilacial Action in Formation, 16; Uses of the Soil to the Plant, 17; Good Farm Soil, 18; Summary, 18; Questions and Problems, 19.

III. Water in the Soll

The Importance of Water to Plints, 20; The Movement of Water in the Soil, 20; Amount of Water Used by Different Plants, 22; Effect of Too Little Water in the Soil, 22; Effect of Too Much Water, 22; How the Soil May be Made to Hold More Moisture, 25; 'The Benefits of Underdrainage, 26; Methods of Drainage, 27; Summary, 28; Questions and Problems, 29.

IV. Tiluting the Soll

Tillage, 30; (Hjicets of Tillige, 30; Preparation of the seed Berl, 32; Regulation of Moisture, 32; Other Uses, 33; A Risk in Tilling, 33; Importance of ( iood Tillage, 34; Tillage Implements - The I'low, 34; Harrows, Plankers, and Rollers, 35; Dry vii 
Farming, 37; Summary, 3S; Questions and Problems, $3 \mathrm{~s}$.

V. EnRiching the SoIL $40-53$

Elements and Compounds, 40; The Source of the Three Kinds of Plant Foods, 42; How These Foods Get Into the IPlant, 43; The Use to the Plant of Each Find of Food, 45; Barnyard Manure, 46; Other Ways of Enriching the Soil, 48; Commercial Fertilizers, 4S; Amendments, 49; Nitrification, 50; Summary, 51; Questions and I'roblems, 52.

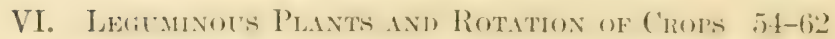
Clover and Its Relatives, 54; Fixation of Nitrogen, 55; Legumes as Nitrogen Gatherers, 55; Other Uses of Legumes, 56; Rotation of Crops, 57; Rotation Is a Weapon Against Pests, 57; Rotation Destroys Weeds, 58; Rotation Practically Enlarges the Farm, 5S; Rotation Regulates the Food Supply in the Soil, 59; The Norfolk System of Rotation, 60; Summary, 61; Questions, 62.

VII. The Unes the Plant Mlake of Its Foon (6.3-70

The Factory of Nature, 63; Oxygen, Hydrogen, and Carbon, 63; 'The Products of Plant Growth, 64; How the Plant Digests Its Food Elements, 66; Changing Starch to Sugar, 66; Changing Sugar to Starch, 67; The Composition of Certain Vegetable Products, 65; 'The Production of Heat, 68; The Production of Seeds, 69; Summary, 69; Questions and Problems, 70.

VIII. Plant Enemes: Weeds, Insects, and Plant Diseases

What a Weed Is, 71 ; Why Weeds Are Enemies, 71 ; Classes of Weeds, 72; Annuals, and How to Kill Them, 72; Biennials, and How to Kill Them, 75; P'erennials, and How to Kill Them, 75; Description of an Insect, 77; Life History of Insects, 7S; 
Classification of Insects, 79; Some Common Cutting Insects, 80; Some Common Sucking Inseets, 83; Insect Control, 84; Nature of I lant Diseases, 85; Some Common Diseases and Their Treatment, 85; Summary, 88; Questions, 89.

IX. The Farmen's Friends: Birds, Toans, Insects 90-102

Birds and Their Food, 90; Useful Birds, 91; Attracting the Birds, 96; Toads and Frogs, 99; Useful Insects, 99; Summary, 101; Questions and Problems, 101.

X. Propagation of Plants by Seens a 103-118

Seeds, 103; Flowers, 103; The Parts of a Flower, 103; Pollination, 106; Cross Pollination and Hybrids, 107; Propagation of Plants, 10S; Quality of Seeds, 109; Age of Seeds, 109; Maturity of Seeds, 110: Selecting Seeds, 110; Testing Seeds, 115; Conditions Affecting Germination, 116; Summary, 117; Questions and Problems, 118.

\section{Propagation by Cuttings and Other} Means . . . . . 119-126

Other Methods of Propagation, 119; (irowth from Buds, 119; Cuttings, 120; Layering, 121; Grafting, 121; The Necessity for Grafting, 124; Budding, 125; Summary, 126; Questions, 126.

Xit. The Farm Garden . . . . . . 127-132

The Importance of the Farm Garden, 127; Position and Soil for the Garden, 127; The Care of the Garden, 12S; Desirable Plants for the Garden, 12S; Summary, 131.

XIII. Farm Crops

Hay and Grass Crop, 133; Alfalfa, 134; Clovers, 135; Corn, 135; Wheat and Other Grains, 137; Field Peas, 141; Potatoes, 141; Root Crops, 142; Cotton, 143; Sugar Cane, 145: Rice, 146; Tobacco, 146; Summary, 149; Questions and Problems, 119. 
XIV. The Orchatn . . . . . . . 150-158

Apples, 150; Pears, 152; Peaches, 153; Cherries and (irapes. 15t; Marketing Fruit, 15t: Transplanting and Pruning, 151; Summary, 158; Questions and Problems, 158.

Xi. (Nattle

The Usefulness of the Cow, 159; The Dairy Cow, 159); Beef Breods, 16.1; Arvantagess in Ratising Cattle, 166; 'The Importance of Good Cattle, 167; How to Improve the Herd, 167; Summary, 168; Questions and Problems, 168

XVI. Mrik And Its Pronucts $170-180$

The Composition of Milk, 170; The Food Value of Milk, 172; The Souring of Milk, 172; The Milk 'Tester, 174; 'The Separator, 174; Cream, 176; Skimmed Milk, 177; Butter, 177; Cheese, 178; Summary, 179; Questions and Problems, 180.

XVII. The Horse $181-190$

Antecedents and Types, 1 si ; Desirable ('haracteristies, 1s1; Heeed IIorses, 1s:3; I)raft Horses, 1s.5; Coach Horses, 1S7; Ponies, 187; Use and Cire of Horses, 1SS; 'The Intelligence of Horses, 189; Summary, 190; Questions, 190.

XVIII. Shmep AND Swine . . . . . . 191-201

Advantages of Sheep Raising, 191; Breeds of Sherep, 191; delvantatges of Raxising swine, 191: Breeds of Swine, 195; Where and How to Raise Swine, 19S; Summary, 199; Problems, 200.

XIX. Poulatry and Bees 202-213

Benefits of Poultry Raising, 202; Breeds of ('hickens, 201; Duckis, (ierese, and Turkeys, 2017; Raising and Care of P'oultry, 207; Summary, 212; Questions and Problems, 212.

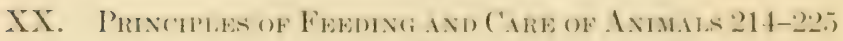

Importance of Animal Food, 214; Classes of Feeds, 216; Balanced Rations and the Nutritive Ratio, 
217; Kinds of Feeding Stuffs, 220; Profit and Loss in Feeding, 222; Care of Animals, 223; Summary, 225; Questions, 225.

XXI. Goon Roans.-Forestry.-Home and School

Grounds . . . . . 226-241

The Farmer's Interest in Good Roads, 226; How to Make and Keep a Road Good, 226; The P'urpose of Forestry, 229; Some Advantages of Forests, 230; What Other Nations are Doing in Forestry, 231; What Our Government is Doing, 232; How a Forest May be Perpetuated, 233; Home and School Grounds, 234; Trees and Shrubs, 234; Vines, 236; Flower Garden, 237; Hardy Perennials for the Farmer's Flower Garden, 239; Hardy Flowering Shrubs Best Adapted to the Farmer's Garden and Lawn, 239; Conclusion, 240; Summary, 240.

\section{APPENDIX}

InsECTICIDES AND FUNGICIDES $243-246$

Bordeaux Mixture for Blights, 243; How to Treat Seed Oats to Prevent Smut, 244; How to Treat Scabhy Seed Potatoes, 245; Kierosene Emulsion, 245: Paris Green, 245.

TABLes 246-259

Table I.-Soil Constituents Contained in Average Crops per Acre, 246; Table II.-Fertility Removed by Different Crops, 246; Table III.-Space and Quantities of Seed Required, 247; Quantities of Seed Required to the Acre, 247; Table IV.-Amount of Nutrients for a Day's Feeding, 248; Table V.-Dry Matter and Digestible Food Ingredients in 100 Pounds of Feeding Stuffs, 250; Fuel Value, 252; Table VI.-Rations Actually Fed to Horses and Digestible Nutrients and Energy in Rations, 253; Table VII.-Pounds of Total Dry Matter and I)igestihle Ingredients (Protein and Carbohydrates, Including Fats $X$ 2.25) in Varying Weights of Fodders and Feeds, 254. 



\section{AN INTRODUCTION TO AGRICULTURE}

\section{CHAPTER I}

\section{THE NATURE OF PLANTS}

I. The Science of Agriculture.-Agriculture or farming consists primarily in raising plants and animals. The farmer aiming to have a profitable business must understand many things about the plants and animals he raises, for without a knowledge of their nature, their habits, and their needs he may labor year after year making only a halfway success of his work. It is easy to waste the good things that Nature has provided for the farmer. It is easy also to increase greatly the ordinary production from the land-if one only knows how.

How to get the best results in agriculture is a question that men are studying all the time. Agriculture is a seience-one of the most useful of all the seiences. Wherever agricultural seience improves farming it benefits mankind. Human beings everywhere are dependent on farming for food. This food in great variety comes from plants and from animals. Animals themselves are dependent on plant growths for food. So we see that the growing of plants by farmers is one of the fundamental occupations of human kind.

The farmer, first of all, should be interested in studying the fundamental facts of his science. He must 
understand how plants grow and what linds of soil are best suited to the errowth of the varions plants. Ile must have a serentifie knowledere of the discases and the encmies of plants and how to overeome them. IIs will wish to know also many facts about cattle, poultry, she(e), and other farm animals. Such fundamental facts we are to study in this book.

2. The Parts of a Plant.-In spoaking of plants now we are thinking of all kinds of things growing out of the earth that provide food-trees, grains, grasses, vines, roots, and all the others. Most plants have roots,

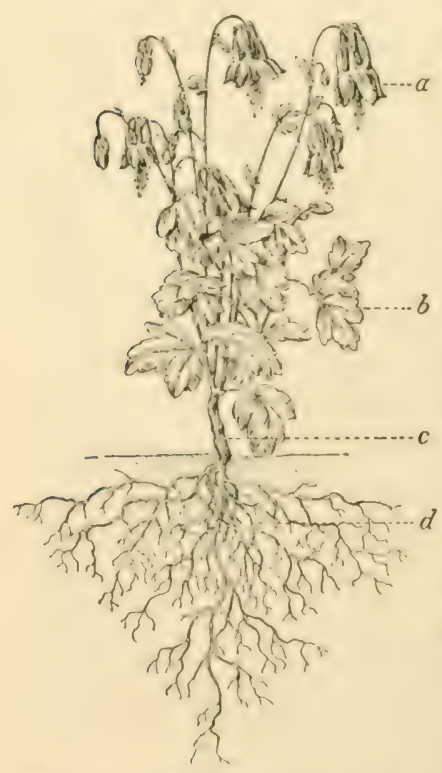

Typical Prant (Columbine). Showing $a$, flower; $b$, leaf; $c$, stem; $d$, roots. stems, leaves, flowers, and fruits or seeds. Some of the lower plants, which are used for food, such as mushrooms, do not have all of these parts. Some are dependent on other plants for their support and for their nourishment. These parts or organs are concerned with the two functions of plants-growth and reproduction. The growth organs are the roots, stem, and leaves; the reproductive organs are the flowers, fruits, and seeds.

Roots.-The roots reach out through the soil, holding the plant in place and gathering food for it. They 
arise from the stem, and branch or divide into smaller roots, until they become fine, delicate rootlets. Except at their tips, the tiny rootlets are covered with still finer root hairs. These root hairs take in food for the plant. They may increase the absorptive or feeding surface of the root seven to seventy-five times.

Stems and Leaves.-The stem is the supporting organ, the framework on which the leaves and flowers are borne. It may be very short and thick as the "crown" of turnips and beets; it may be very slender and light as in the grains and grasses; or it may be large and strong

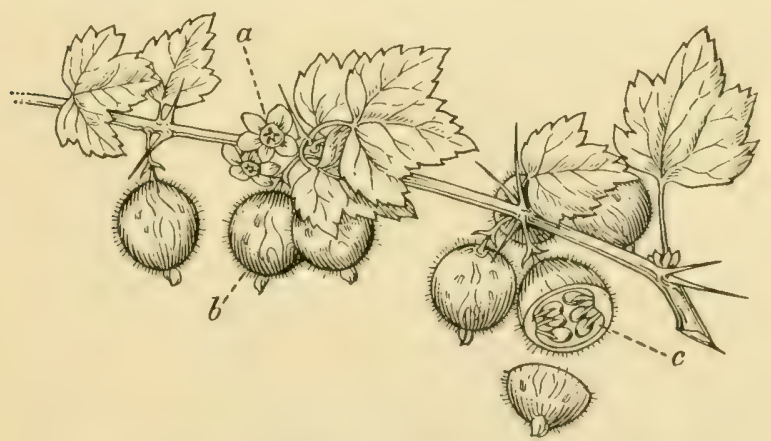

Gooseberry. Showing $a$, flower; $b$, fruit; $c$, seeds.

as in the trunks of trees. The food absorbed by the root hairs passes through the larger roots and the stem to all parts of the plant. On the stem and generally in the axil of a leaf, buds are borne which produce branches bearing either leaves or flowers. The leaves help gather food by absorbing gases from the air. And it is in the leaves that the food elements gathered by the roots and leaves are made ready for the use of the plant. 


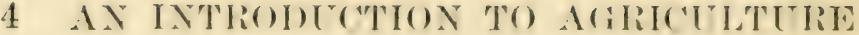

Plate the stem of a plant (hilsatm) in water colored with red ink and wateh the patsigere of the watcr up the stem and into the leaves.

Flowers, Fruils, and Seeds.-The flowers on a plant produce the fruit and seerls. The sererl, as you know, contains the young plant. 'The parent julant stores forol in the seed, and this ford the youmer plant uses in sending out its first shoots and getting ready to glean its own living.
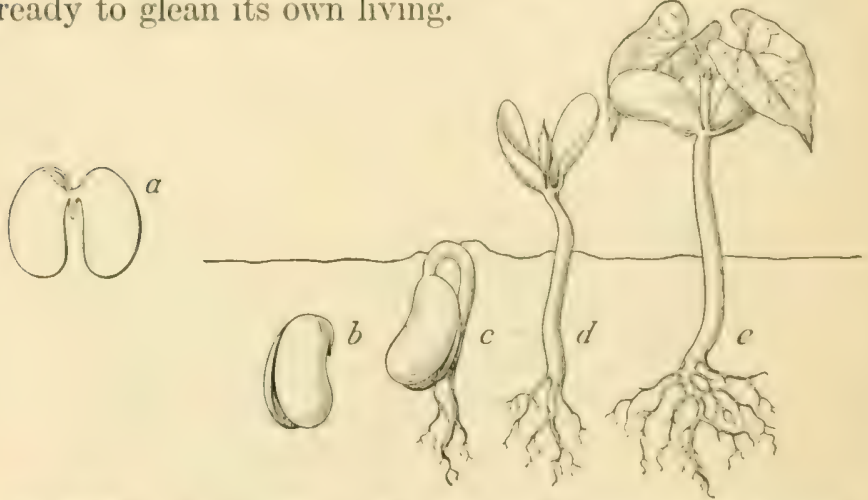

Lima Brax. a, cotyledons opened to show hypoeotyl and plumule; $b$ to $e$, succesive stages in gremination showing development of hypocotyl, roots, cotyledons, stem, and plumule.

3. How a Plant Grows.-You may have seen how a plant begins to grow from the serel. It sends a shoot upward toward the light and another shoot downward as a root. The upwarl shoot becomes the sitem. It branches out and has leares, and so makes the fullgrown plant which we see. The root, as it grows, also divides into many branches which rum through the ground. 
If you put some beans or other large seeds in water or damp sand, you ean see how they sprout. On the outside will be found two coatings. Beneath these are two leaves, thick and yellow. They contain the nourishment on which the young plant begins its life. These leaves are called cotyledons.

Place some large seeds, such as beans or peas, in water over night. Then take out some of them and study their structure. Place the others in damp, sawdust or sand. Continue for several days the study of the little plants.

Lay the first leaves apart and you will find between them two tiny leaves supported by a minute stem. These inner leaves are called the plumule and the stem is called the hypocotyl. The hypocotyl grows and lifts the leaves above the ground. From the hypocotyl also the first root starts in its downward growth. In some plants the plumule develops into the first real leaves; in others the cotyledons become the first leaves above ground. Corn and certain other seeds have only one cotyledon.

4. How the Plant Gets Its Food.-The plant starts its life by feeding on the food stored in the seed. But as soon as its leaves have reached the sunlight and its roots begin to spread out through the soil, the plant must find and make its own food. Air, water, and mineral salts in the soil are the plant's food materials.

Sprout grains of corn, wheat, barley, ete., between two pieces of damp eloth inclosed between two plates. Place two or three matches with the seeds to prevent mold, and set the plates in a warm place. In at few days study the seedlings, ex- 


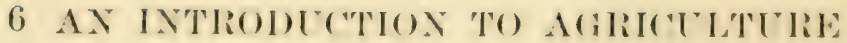

amining the parts. Notice the hairs on the routs. (ompare the different kinds of plants.

The plant ran take in nothing in solid form. All its food from the soil eomes to it dissolved in water, which ('an pass realily from the soil through the root hairs inte the tiny rootlets. The soil water contans carlonie: acid derived principally from decaying oreanic matter which helps it to discolve the mineral compounds in the soil. 'The water passing into the root hairs takes with

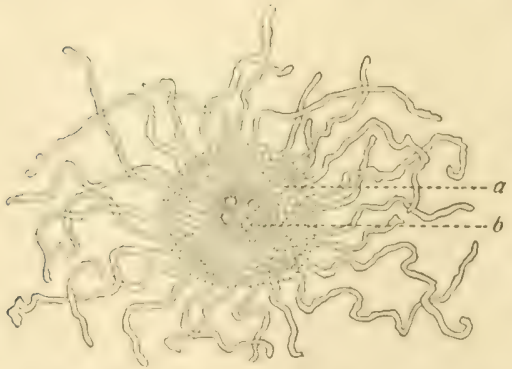

Ciross Sictun of a Ront Showixg the

Rоoт Hains, $a$, bark cells; $b$, duct for passage of water and air.

it the mineral salts that are necessary to the plant's health and growth. These mineral salts are really several substances mixed together, but all are called salts. While the salts are disiolved in water, we camnot see them. Their tiny invisible particles are mixed with the particles of water in what is known as a solution. If we boil some watre until it has all eraporated, we shall cenerally find in the bottom of the kettle a white substance that looks like common salt. This is the mineral salt which was in the water but which did not evaporate with it. When we hurn plants the mineral parts are left in the form of ashes.

The plant feeds from the air as well as from the water in the soil. Its leaves alsort) gases from the air, and these gases, esperially the cartom dioxide, are used 
in preparing the food for the plant. In some way that we do not wholly understand, a plant has the power to combine the water, the mineral substances from the soil, and the gases from the air so as to make food for itself. This can take place only in sunlight. In this process the leaves return to the air through the stomata a gas which we call oxygen and more or less water.

5. Conditions of Growth.-In order to grow well, the plant must have the proper conditions of heat, water, air, light, and food. Until the weather is warm most plants do not even sprout. Light is very essential to the life of plants; in the dark they stop growing or grow only a little and weakly. A certain amount

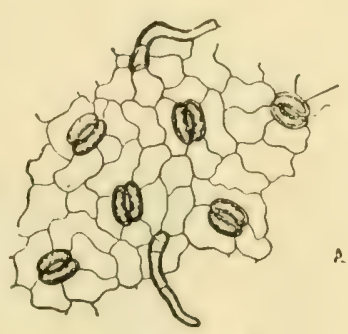
of water must be in the soil

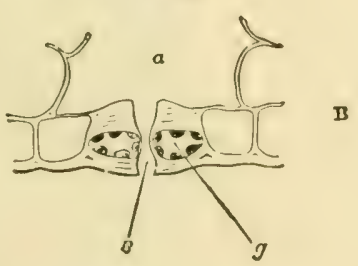

within reach of the plant, or it will wither and die. There must be a free circulation of air, and the proper amount and kinds of plant food must be in the soil.

I. In two flowerpots plint some grains of wheat or oats, after soaking in warm water for several hours. When the seedls have germinated, place one flowerpot where a strong light will reach it from all sides and the other in a window where the light eomes from only one side. Watch the results.

2. After a lawn has been mowed, cover a small section of it with a box, bottom upward. The box may be a foot or more 


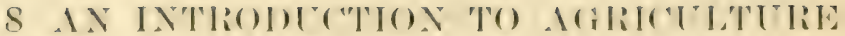

spluare. After a few days the grass bemeath will hase lost its green color and ceased to grow. Why?

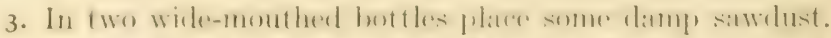
After soblinge in water a hamelful of eratios of wheat or oats plate half in ateh bettle. ('ork ome bottle very tierhty. (o) vering it with vatselime, amel leatre the othere opere. Watrh the results.

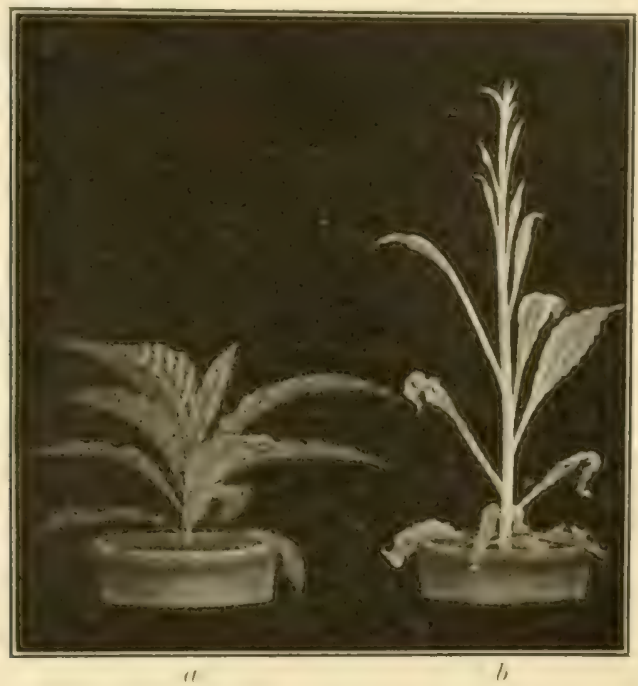

Tóacco Plaxts. $a$, grown in the light; $b$, grown for two weeks in darkness. After Errera and Laurent.

6. Plant Food Must Be Usable.--The plant food in the soil must be in such a comblition that the plant ean use it. Many stones in the fiedel may he full of plant food, but the plant cammot use it in this form. If a stone is broken almost to a prowerer, even then the elements the plant neesls may he eombined with something else so that the plant eamont gret its food. This food 
must be ehanged and dissolved in water before the plant can use it. It is as if a hungry boy stood outside a locked pantry door. The food is there, hut it ean do him no good until the door is unlocked. So we say the plant food is locked up.

One thing that helps unlock this food is air in the soil. Among the loose particles of soil there is air as well as water, and the farmer must take eare that the air is not shut out. Much of the farmer's work consists in releasing this food so that the plant ean get it. How it is done we shall learn later.

\section{SUMMARY}

The plant consists of root, stem, leaves, flowers, and fruits, or seeds.

The food of the plant consists of air, water, and mineral salts.-Food material in the soil is dissolved in water and ab)sorbed by the root hairs of the plant.-- (iases from the air are absorbed by the leaves of the plant.

The conditions of plant growtin are proper heat, moisture, air, light, and food.

Much of the farmer's work consists in making plant food usable.

\section{QUESTIONS}

I. Why is agrieulture one of the most useful of all the sciences?

2. Name the parts of a plant. Tell the uses of each.

3. Why are root hairs so important?

4. What are the right conditions for germination and growth?

5. Name and give the use of each part of a seed.

6. In what form is plant food usually found in the soil?

7. Why cannot the plant use stones for food? 


\section{CHAPTER II}

THE SOIL

7. The Composition of Soil.-By soil we mean that part of the earth's crust in which plants grow. It is the loose decomposed layer of mineral matter resulting from rock decay which fur-

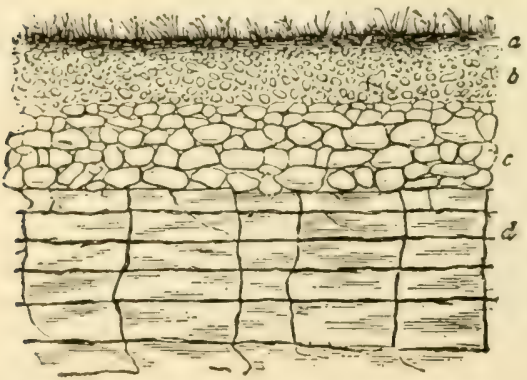

nishes food and foothold for plant and animal life. Soil may be from a few inches to several feet in depth. The earthy material beneath the soil is called the subsoil. It

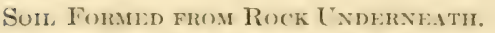
$a$, soil with grass growing in it; $b$, subsoil, coarser and more rocky; $c$, coarse, loose rock; $d$, rock in layers, cracked. $d$ changes to $c, c$ changes to $b$, and $b$ to $a$. is generally harder and colder than the surface layer of soil and it is generally not suitable for plant growth.

Soil is usually a mixture of decayed rocks, plants, and animal matter. We say that a rock is "decayed" when it crumbles up. You may have seen in a gravel hed stones whose outer surface can he erumbled with the hand. The crumbling of rocks helps to make soil. The 
pieces that break off are sometimes small and sometimes large. In many soils there is a gradual grading from the fine soil on top, down through coarser and coarser parts, until rock is reached.

Plants on the surface of the ground wither and die, and gradually become a part of the soil. In some places in the woods the fallen leaves have lain undisturbed for centuries. They have decayed and made a darkcolored substance in the soil. The roots of plants that have died, rot or decay and add other vegetable substances to the soil. These decayed parts of plants give to the soil some material that is very valuable for the growth of plants and improve it in other ways by making it light so that light and water will circulate through it readily, causing it to warm up earlier in the spring. Animal matter also enters into the soil and helps to make fertile soil. The decaying plant and animal matter in the soil is called humus.

8. Kinds of Soil.-Most soils are made up chiefly of four different grades of materials-sand, silt, clay, and humus. Sand is a coarso-grained material, silt is finer, and elay finer still. Humus has been deseribed above. If the soil consists of these four materials in fairly equal proportions, it is called loam. If there is more of one material, the soil is given a corresponding name, as sandy loam, clay loam, ete. If there is much sand, the soil may be called light sandy, or if there is much clay, the soil may be called heavy clay. The terms heary and light do not refer to the actual weight of the soil, but to the difficulty in working it because of its stickiness or lack of it. The physical nature of any soil is largely de- 


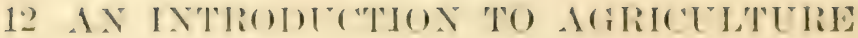

tromined by the kind of rock from which it is clerived. sime of the more eommon of these rocks are deseribed below.

Examine the soil in the garden and field and determine

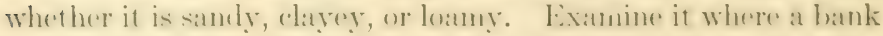
has been eut through and notire the variations as we go down from the surface.

Girmite, the rock eommonly used for mommments and buildings, oomsists mainly of three minorals mised together-quartz, felds])ar, and miea. When a wranite rock decays, the quart\%, boing hard, romains as sand. The foldspar and the mieas are piatly dissolved and brak up) into fine particles, which make cla!y.

stamlstome is made of erains of sand eementerl together. The sand may be coarse or fine, white or colored.

Limestome is a softer stone of many grarles and all colors from black to white. It is marle of the dust of

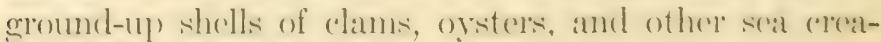
tures. The shells, moved back and forth over stomes ol other shells by the waves, are gromed to a fime dust. This dust is worked together into a hard mass and forms rock. Clay and sand washed down by the rivers mingle with the shell dust, and thus the limestome sometimes contains olay and sand also. When limestone decays, much of it is dissolved and carried away, leavinge the clay to settle and form a clay soil. Somotimes limestone may contain so much simel that its decay makes a sandy soil.

If possible, obtain spreimens of eranite, sandstome, and limestone. With a hammer break up) a juece of each into frag- 
ments as small as peas. Take three bottles half full of water and put into them pieces of the broken stones, free from dust or dirt. Put only one kind of stone in each bottle, and have the pieces about an inch deep on the bottom. Cork the bottles carefully and shake them several times a day for a week. Observe in which bottle there is the greatest accumulation of soil.

9. Formation of Soil-Rock Weathering.-The decay of rocks and the making of soil take place chiefly by a process called weathering. Let us see how weathering acts on the rocks.

Granite, as we have learned, consists of three minerals cemented together. If one of the minerals is dissolved, the rock will fall to pieces. You may have seen plaster break and fall from the ceiling of a room when water has leaked through from above. The plaster is made of lime and sand, and when the water disolves the lime, the plaster ean no longer hold together. In a similar way, water working on a granite rock may dissolve a little of the feldspar or mica, and then the granite crumbles.

Limestone also erumbles when water dissolves some of the cement that holds it together. If the water working on limestone contains a little acid, the stone decays faster. Water in the ground is nearly always slightly acid.

Water sometimes works its way into a rock and freezes there. Now we know that water in freezing expands. If a bottle full of water freezes, the bottle is likely to be broken because of the expansion of the water. In like manner, water freezing in a rock tends to split off a layer of rock. 


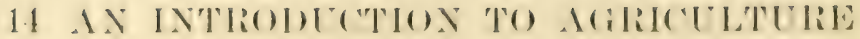

Sumlight on a rocki temek to flake off the ontside surface. 'The heat serms to make the rock expland and crack, just as the top of a stove mat crack from the ex-

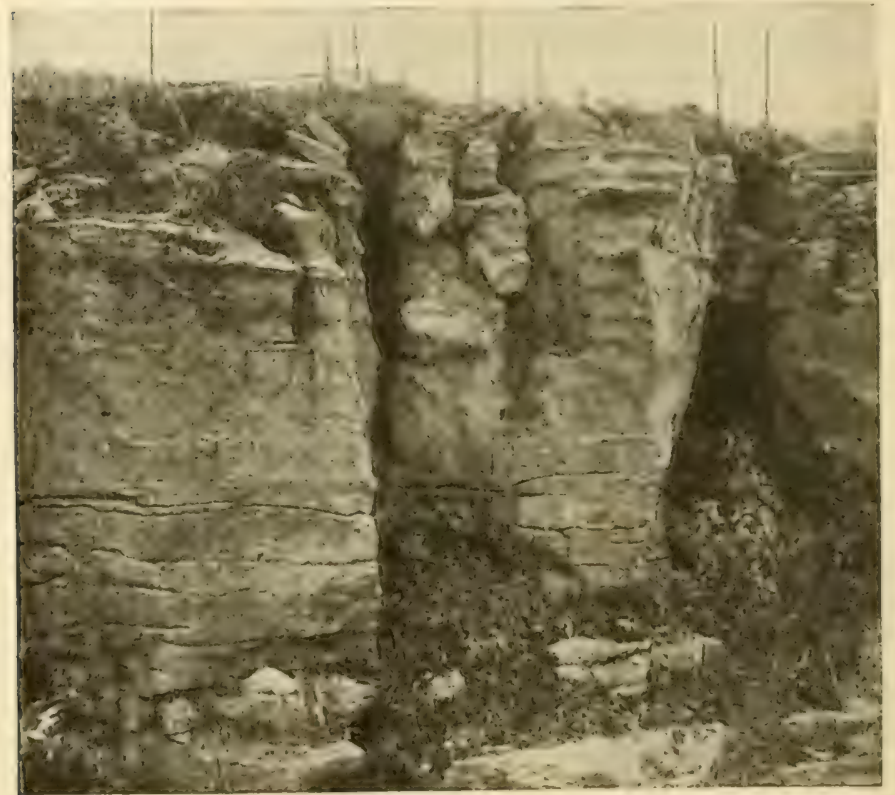

WeATHERED Limestone.

Wasting is by solution. Water finds readiest acecess along joints.

pansion caused by heat. When the weather turns colder at night or in the winter', the rock contracts and this helps to make it flake off. The various constituents of which a rock is eompresed expand differently moker the efferet of heat, and the many different strains which result break the rock apart. Thus the changes in temperature are eonstantly working toward the loosening of par- 
ticles of rock. In regions where the soil is not protected by vegetation, the wind is an important factor in breaking down rocks. Particles of sand caught up and driven against rock surfaces exert a surprising grinding power. ('liffs and bowlders are undermined in this way.

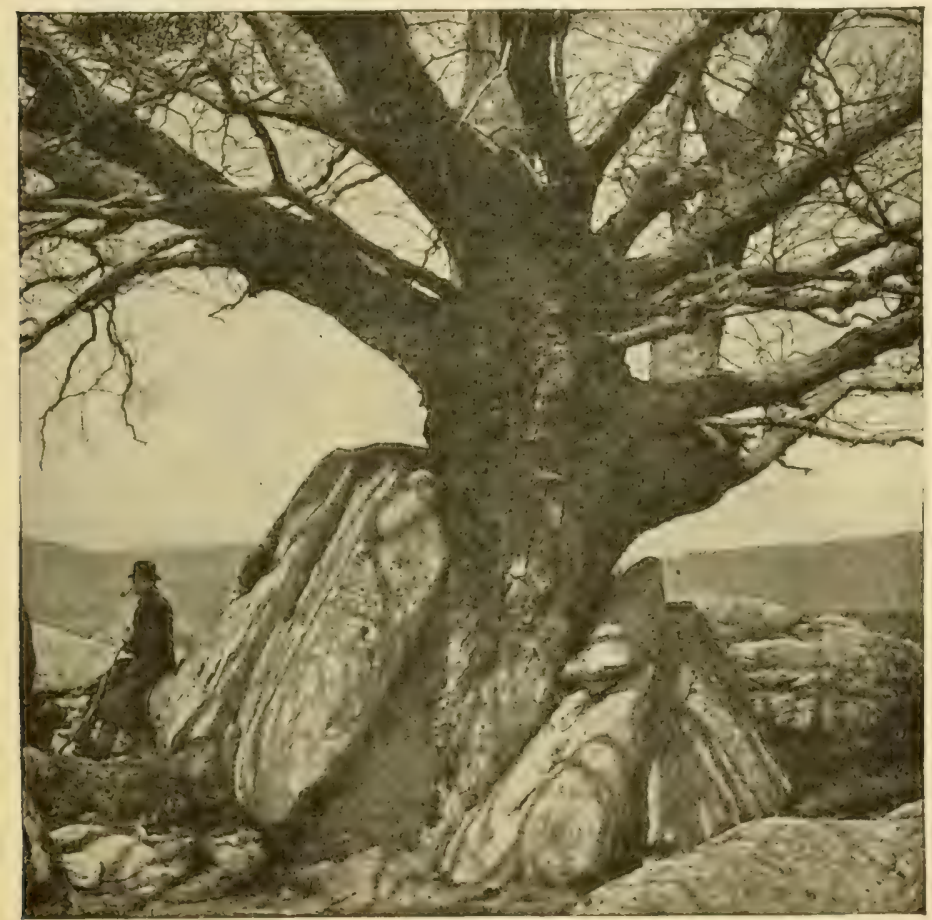

Rocks Wedged Apart tzy Growing Tree. Western Massachusetts.

Sand driven along by a current of water acts in the same way.

P'ants also help to deray rocks. There is a class of 


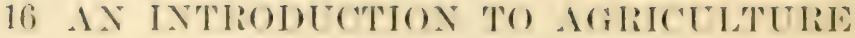

plants. called mosses and lichens, that grow on rockis and that disiolve the rock material by acids which they contain. Wherever plant roots eome in contaret with resek, they act on the rock partieles and help to crumble the rock. If they get into the rock creviees and grow they may fill the ereviees and fores the roek apart. The acid developed in the formation of humus in the soil is another agent in the breaking down of rock.

We see, therefore, that the chief agents that hreak down rocks are water, acid, heat, and cold, iee and frost, winds, certain plants that grow on rocks, plant roots, and humus. We call these the agents of wrathering.

Search a gravel bank for specinens of weathered stones.

If a running brook is near, notire the coarse stomes in the middle of the brook and the finer ones nearer the edge. At the very edge, or where the water runs slowly, there may be only mud. After a rain notice the sorting power of water as shown in the road or street.

I0. Glacial Action in Soil Formation.- Some of the richest soils in Ameriea were formed by the action of glaciers many centuries ago. All over the northern part of our country there once passed a glacier sereral humdred feet thick. This grlacier tore up rocks and gromul them to bits, and earried and distributed the piecess over a wide area. Thus a great rariety of rock materials was mixed together to form the soil.

Such soils are likely to be more fertile than these formed from one kind of rock or from the rocks in one place. They do not wear out so equickly, that is, their material neceded for plant growth is not so soon exhausted. 
Ir. Uses of the Soil to the Plant.-Wre are interested in this study of the composition of soils because it is largely from the soil that plants get their sustenance. By understanding how the soil is made, we learn how to get it into the right eondition for the growth of plants.

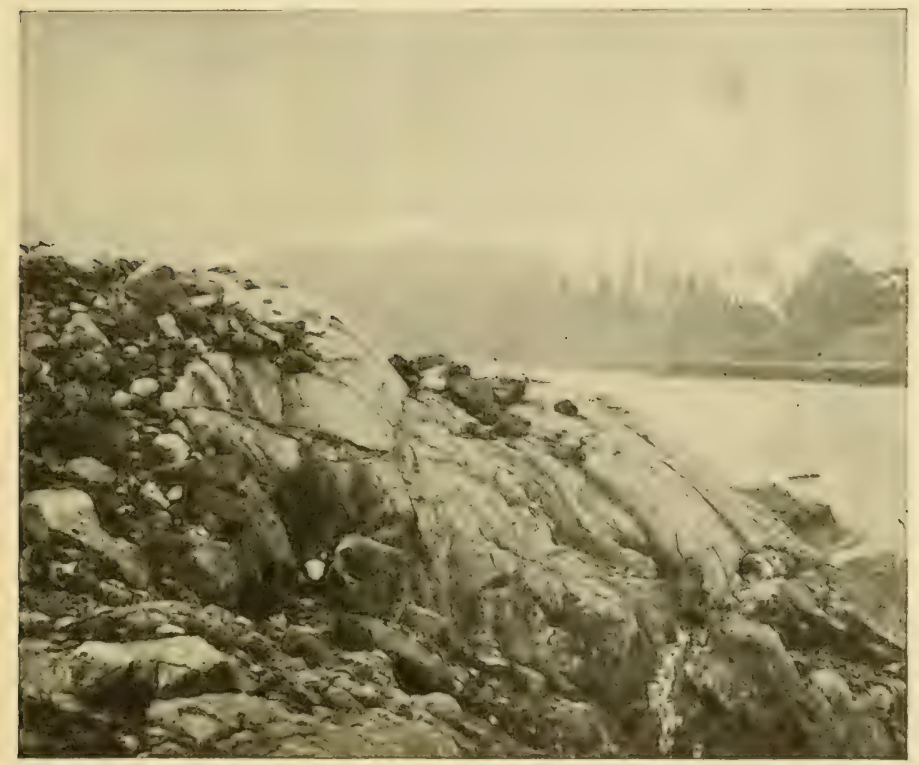

A Mountain Spur Smoothed and Rounded by a Glacier. Glacier Bay, Alaska.

The soil provides the support in which plants are anchored; trees need a crreat mass of soil to hold them in place. The soil furnishes the water and much of the nourishment that plants need. The soil also helps to give the plant the right amount of heat. It acts as an absorber and storchouse of heat. If the plant's roots 


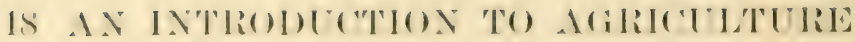

were exposed to the sum and the wind, they would often suffer form for muth heat, and as often he for (o)ld. The soil, like a hlanket, hoth kereste heat in and keregs it out.

12. Good Farm Soil.- In order that the soil may do its important work properly, it mus lo in the preper condition. This moans that it shomld not he lomply or too hard or too loose. It must he made nup of the right proportion of samel, alay, and hommes. It shomlel mot he wet enough to cake or too dry to smyply the plants with the mereded mositure. It must be rich; that is, it must have plenty of plant food in the emolition in which

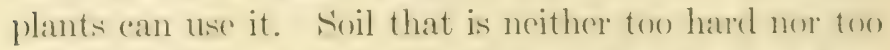
Ionse is said to be mellowe. I fertile soil hats all of these conditions just richt for the production of good areps.

\section{SUMNARY}

All soil is made from the deray of rocks, plants, and animals. --The principal soil-forming rockis are erranite, sandstone, and limestome. -The principal kinds of soil ate same? soil, rlayey soil, light samely and heary elay soils. - llixtures of sambl, silt, clay, and humus are called loams.

The ehief process's of soil making is called weatheringe. - The principal agents of weathering are water, atod, wind, loat and rold, frost and iere, and growing plants.- Inother important

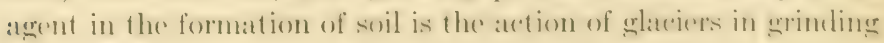
down rocks.

The soil is neeessary to smpurt the plant and to fumish mourishment and water supply. It affords a plare where plant food maty rhange its form, and where the heat of the sum may be alsorbed and stored. - In order to do this work properly the soil must be in the right condition. 


\section{QUESTIONS AND PROBLEMS}

x. Are there gravel banks with many kinds of stones near where you live? If so, they are probably glacial drift.

2. How can you tell granite from sandstone? (iranite from limestone? Sandstone from limestone?

3. Which is darker colored, humus or sand?

4. Why is the decay of rocks called weathering?

5. (ieologists tell us that when limestone weather', ninetysix per cent may be dissolved and earried away. How many culbe feet of limestone would make twelve cubie feet of soil?

6. How many square feet are there in an acre? If a farmer plow's eight inches deep, how many culbe feet doess he move in plowing an acre?

7. What is the chief operation that you have seen farmers perform to get soil into right condition for plint growth? How do you think this helps?

8. Why do farmers call a sandy soil light?

9. Would a rock crumble more where the climate is even or where it is changeable?

ro. Can you see any reasons why the surface soil is better than the subsoil? Give them. 


\section{CHAPTER III}

\section{WATER IN THE SOIL}

13. The Importance of Water to Plants. - II ithout plenty of water in the soil. plants cammot thrive. You alreaty know why this is so. Watre itsolf is a plant food, and in the water is elissolvere all the other food that a plant takes from the soil. The water must be in contalet with the errains of soil so as to gert from them the mineral salts needed to foed the plant.

I4. The Movement of Water in the Soil.- T'alt of the water that falls during a rain sinkis into the soil. Fome of it stays near the surface and some goes derep into the subseil. You kinow how the water sometimes rums thromeh the soil in a flowerpot and eomes ont of the hole in the bottom. If the soil is dry, and you wive the plant only a little water, nome of the water rums out, but all of it is held among the soil wrains, which now look moist instead of dey. That which stickis to the particles of soil is callod film water. That which rums through the soil is called free water.

Everporation.- If the flowerpot stancts in the sum after it has beren watered and the free water has rum off, the soil on top will dry out. The water in it has passed off into the air. It has turmel to valur, or, as we say, has evaporated. 
Porosity.-As the soil on top dries, the water in the lower part of the flowerpot gradually moves upward. The film water fills the tiny spaces between the grains of soil. When these spaces in the upper layer of soil are emptied by the passing of the water into the air, more water creeps up from below to fill them. You know how a blotter takes up ink and how a sponge absorbs water. Blotter, sponge, and soil are porous objects. Between the particles of which they are made are tiny spaces or pores. Into these pores the liquid

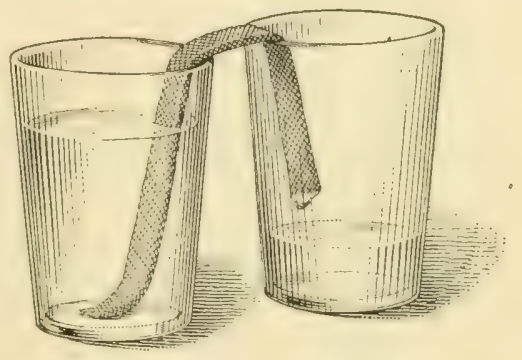

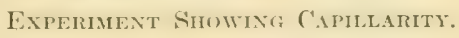
moves.

Capillarity.--The water, we have said, rises through the soil. In a lamp wick the oil moves upward from the base of the lamp to the surface where the flame is. Capillarity, ${ }^{1}$ or eapillary at traction, is the name given to the foree which eauses any liquid to rise through a porous substance.

Take two glasses; fill one with water, and plate them silde by side. Place one end of a lamp wiek in the glass containing the water, and let the other end hang over into the empty glass. Watch the results.

${ }^{1}$ Capillary means hairlike. The capillary action of water is best shown in "hairlike" tubes, that is, small grass tubes open at both ends. If such tuloes are placed upright in a pan of water, the water will rise in them. 


\section{I5. Amount of Water Used by Different Plants.-} The almoment of water which plants contain, "Non when

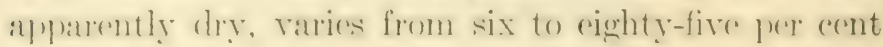
of their total wright. The guantity of water in some plants, of partsof plants, is shown by the following table:

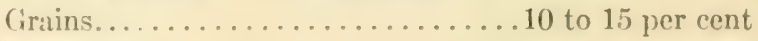

Dry beans. 12.4 "

Gireen-apple twigs. 50

Pontatomit. si)

Green grass. S5

But the plant aretually nerels much more water than is shown by such a table. 'To kerese hoalthy, a plant must romstantly have a gerat quantity of water passing through its strms or manehes to the loaves. The water evalporates from the leaves into the air. Fxperiments have shown that, for asele poumd of dry grain to be harvesterl, three humdred to five humdred pounds of water shomlel pass thomegh the plants producing the grain.

I6. Effect of Too Little Water in the Soil.-.. I plant will yuickly starve if it has mot omough water. Water itsolf is the most important plant food, and it is the morlium for the transmission of plant forol, for the plant gets its mineral food in the water which its roots ahsorb.

IIrels and other plants that have litte wooly lis-sue in their stroms wilt and lleo(y) if they have not sufficient watrer. The watre is moreled to fill out the strmes and liore the plants stifl and upright, as woll as to hring food from the soil.

17. Effect of Too Much Water. l'lants maly suffer from too murh water in the soil as werll as from too little. 
Air is needed in the soil in order that the plant may get its proper food (see. 5). If the soil is very wet, so that water fills all the spaces among the grains of soil, there will be no room for the air. Fou may understand better how the soil holds both air and water if you think of a wet sponge. The substance of the sponge holds water, and all through the sponge are tiny open spaces, or pores, filled with air.

Too much water may injure the plant in another way. The roots of most plants will not go down into water. If they find the gromel too wet, they will spread out near the surface instearl of going deeper. Later, when the weather becomes hot, the roots, being near the surface, will dry up. Too much water at first results in too little available water later.

Still another thing we must remember about watersoaked soil. Ground that is very wet is cold. More heat is required to wa:m water than to warm soil. Then, too, from wet ground water is all the time evaporating. As it passes off into the air, the water takes with it some of the warmth in the ground. This warmth is needed for the growth of plants, and especially of seceds. Rappid evaporation from wet soil wastes it. When the sun is warming the land in spring, wot soil is not made ready for seed planting so soon as soil with only a moderate amount of moisture. A wet soil is likely to be oreracid or sour, and not well suited for crop) (arowth.

Thus we see that for many reasoms it is important that the soil for most plants should not be water-soaked. The soil is a storehouse for water. One of the chiof problems of the fammer is how to regulate the sup)- 


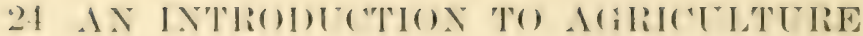

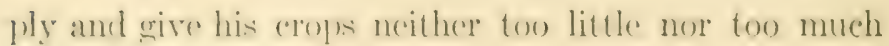
water.

For this and some other experiments a small spring balane weighing by omeses up to four poumls is desirable. Provide five pint bottles with the bottoms cut off as follows:

To rut off the bottoms of the bottles, saturate a string with kerosene or aleohol; let it drain and then wimel it two or three times aroumb the bottle near the bottom. Tie the string tierhty and rot off the ends. Tight the kerosene and let it hurn, holding the bottle bettom upward. Is soon as the kerosene is nearly or equite done burning, dipe the bottom of the bottle into water, if the botfom has not already aracked off. ('ork the bottles with erorks havine notrhes ent in the sirles so as to allow water to enter when the necels are immerserl in water. Tie a string around the neck of each inverted bottle and hring the

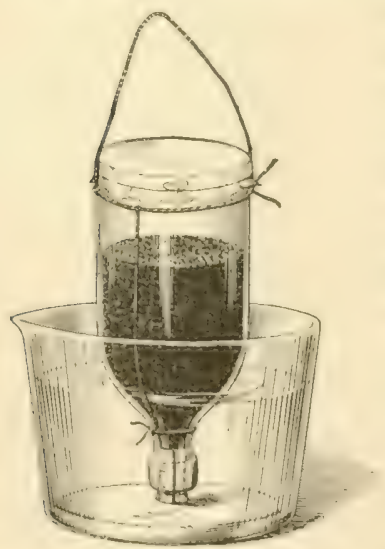

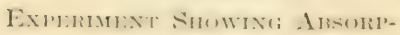

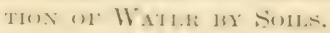
string up near the bottom of the bottle so as to make a noose around the bottle. Make a loop in the end of the string into which the hook of the balance may be placed. Weigh each bottle, and record the weight. Place in each bottle a pound (or other known weight) of some kind of soil, as, for example, gravel in one, sand in another, poor soil in the third, loam in the fourth, and leaf mold in the fifth. Stand the bottles bottom up in old tin cans, each can containing the same amount of water. Corer the open enels of the bottles with a piece of rubler sheeting to prevent evaporation. After two or three clatys weigh aideh bottle to sere which soil has gained the largest amount of water.

fimply the rematining water from the cans, replate the bot- 
tles, and uncover the ends to allow the water to eraporate from the soil. Note which kind of soil loses water rapidly.

\section{How the Soil May Be Made to Hold More Moisture.} -Let us see what the farmer can do to make the soil hold more moisture. You will remember that water in the soil finds its place in the minute spaces between the particles of soil (Nece.6); and you have learned that by capillary attraction the water ereeps up along the surfaces of these particles of soil (sece 14). By brealing up the soil into fincr pieces the farmer may increase the total surface and also the total space for the water to fill.

This will be clear if you think of cutting a culbe of cheese into pieces. If the cube is one inch scuare, its surface contains six square inches. By three euts with a knife the inch cube can be made into eight halfinch eubes. The surface of these eight cubes together is twice that of the inch cube. The inch cube offered no space into which

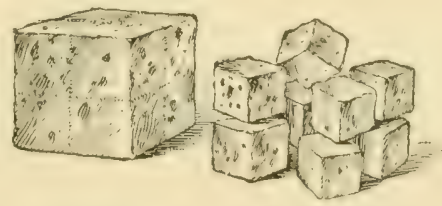

Experiment Showing Increase of

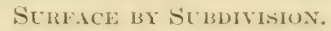
a liquid could be poured, but the eight smaller cubes thrown together offer many little cracks and creviess. This illustrates why the farmer should make his soil fine by tilling, the methods of which we shall study in the next chapter.

The soil is made more porous and able to hold more moisture, without beeming eold or sogery, hy adding humus (sece. 7) to it. Bamyard manure or plowedunder crops, of which we shall learn in seretions 35 and 


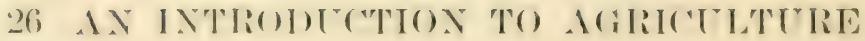

36, increase the humms in the soil. Humus ean hold more than seven times ats much water as the same amoment of sand (reckomed hy weight) and hold. A little humms mixerl with soil incerases the aldility of the soil (1) held water to a degree equal to nearly twice the weight of the humus.

(iet three ex:mules of garden soil, one from a depth of six incles, one from a depth of twelle inches, and one from a depth of eighteren inches. Weigh ats aterurately ats possible eight oumes of eath and thoroughly dry each sample in a warm plater. Wergh each dried sample. Divide the less in weight by the original weight, to find the pereentage of water that each contained.

19. The Benefits of Underdrainage.--The best way to regulate the amount of moisture in the soil is by drainage. Farmers have various methods of draining land, that is, of earrying off the superfluous water that falls or serpes into the ground. From what you have just reasl (serec. 17) about the effect of too much water in the soil, you will understand some of the benefits of drainage. If the water is carried off, there is more room for air in the soil. The roots will grow deeper. The soil will be warmer. Exeess soluhle substances in the soil, which may he injurious to (rop growth, will be removed and the soil will really provide more arailahle moisture during the season.

The fact that in drained land the roots ean go deeper is beneficial in several ways. These roots will feed in the deepere soil and will take leses water from the surface. So long as the water is not drawn from the surface layer of soil, the moisture below will not rise by the foree of 
capillarity (Sec. 14). It will be stored up) until neerled. Later in the season when a dry time eomes, this store of water will rise toward the surface as the moisture there evaporates. Thus you see that drainage improves the condition of the soil in such a way as to increase its capacity to hold available water without the evils that attend the presence of superfluous water.

Deep-growing roots also open up places for the air to penetrate farther into the soil. As underground water is drained off, clay in the soil shrinks and crackis, and these cracks offer another means by which air gots into the soil. It is important to provide drainage for a clayey soil; for a sandy soil this generally is not necessary.

When land is drained, the water from rains ean sink into the ground. Otherwise the rains may wash away the surface soil and injure plants.

20. Methods of Drainage.--The loest method of underdrainage is by trenches, with hollow tiles at the

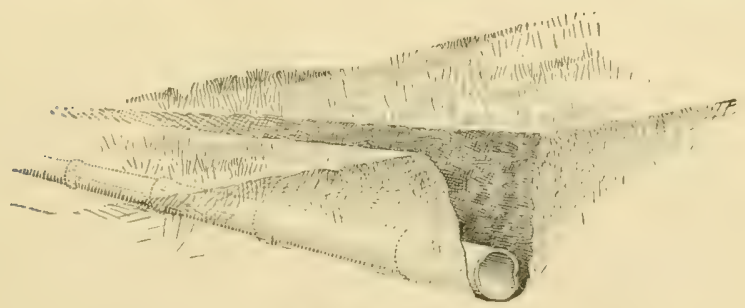

A 'Tile: Drain.

bottom. The trench is dug two and one half feet to four feet deep. The tiles are one foot long or more and two to eight inches in diameter. They are placed end 
to end, without ermenting, on at gradual grade, and the trenech is filled with wath. The wather from the soil gets inte the tiles through the small splates where the enels join and flows through the pipe of hollow tiling. The rows of tiles are platered through the fiedel at distanees aptart varying from thirty to ome humdred foret. Sometimes stoness are used instratel of tiles. They are lated in the diteh so ats to form a chammel for the water.

Farmers sometimes drain their land by open ditehe's, but it is hated to work a field (at up in this way. When such ditches must be had, it is best, if posible, to malise them so broble and gently sloping as to permit their being kept in erassis and readily mowed with a mathine. Sometimes the ditches are filled with stomes or brush, and it is them more diffiente to kerep) the wereds down. such an arrangement is much less sat isfactory than tile drains, which are less expensive to liere up, are more premanent, more efferetive, leare no obstruetions on the surface, and waste no land.

\section{SUMMARY}

Water exists in the soil as free water and film water.- Water moves through the forous soil hy the foree of captillarity.-Different cropse use 300 to 500 prounds of water to produce one pound of dry matter. - The water serves the plant as food, to carry food, and to render the plant stiff and rigid. -Too little water rohs the plant of its food and allows it to wither. - Too mueh water in the soil injures the plant hy keeping air out of the soil, by presenting the ronts from penetrating the soil, and by making the soil cold.

The moisture-holding capaleity of the soil may be increased by tilling, by adling humus, and by drainagre-CUnderdrainage 
allows the plant to root deeply, opens up the soil for the admission of air, deepens the feeding ground of the plant, increases the eapacity of the soil to hold water, and lessens washing by rains. Draining by tiles is the best method of underdrainage.

\section{QUESTIONS AND PROBLEMS}

r. What kind of soil allows the free water to pass through most readily?

2. Give illustrations of capillarity, or (apillary attraction.

3. Which would be better, to water a lawn or garden a little and do it often, or give it a thorough soiking once in a while? Why?

4. Would you pick lettuce early in the morning or in the middle of the forenoon? Why? (Sec. 16.)

5. Can every piece of land be drained? What conditions are necessary in order that it may be drained?

6. It is said that wheat uses 453 pounds of water to produce one pound of dry matter. At 30 bushels to the acre (60 pounds per bushel), how many tons of water per acre would be required?

7. One inch of water over an arere weighs nearly 100 tons. Can you find what is the weight of the annuil rainfall in your vicinity? How many inches would be neeessary for the number of tons found in Question 6? The wheat straw will weigh one and one half times as much as the grain. How much water will it require?

8. Why will a crop on well-drained lambl have more time to mature than on undrained land?

9. If a cube an inch on eateh side is divided into eubes one eighth of an inch on wath side, how many eubes will there be?

ro. How many times as much surfare will the little cubes have? 


\section{CHAPTER IV}

\section{TILLING THE SOIL}

2x. Tillage.-Tilling the soil is one of the means by which farmers improve their land. Plowing partly inverts the soil and grincls the particles together. Cultivation stirs and loosens the surface soil and therehy makes it finer. These operations change the texture of the soil, as we say.

When an entire field is tilled, the operation is called general tillage. This is done ustally to prepare the soil for the planting of seeds or to mix with the soil manure that has been spread over the surface.

sometimes after the plants have eome up the soil is tilled between the rows of plants. This is ealled intertillage.

In its larger sense the word cultivation means the same as tillage. Hore narrowly, it means the use of the cultivator to stir the surface soil.

22. Objects of Tillage.-Briefly, the ohjeet of tillitger is to put the soil in such a physical condition that it makes an ideal home for plant roots. There are many reasons why plants need a loose, fine soil. If the soil is in lumps, the tiny roots camnot enter it casily, and it will neither support the plant nor give it food. Tillage 


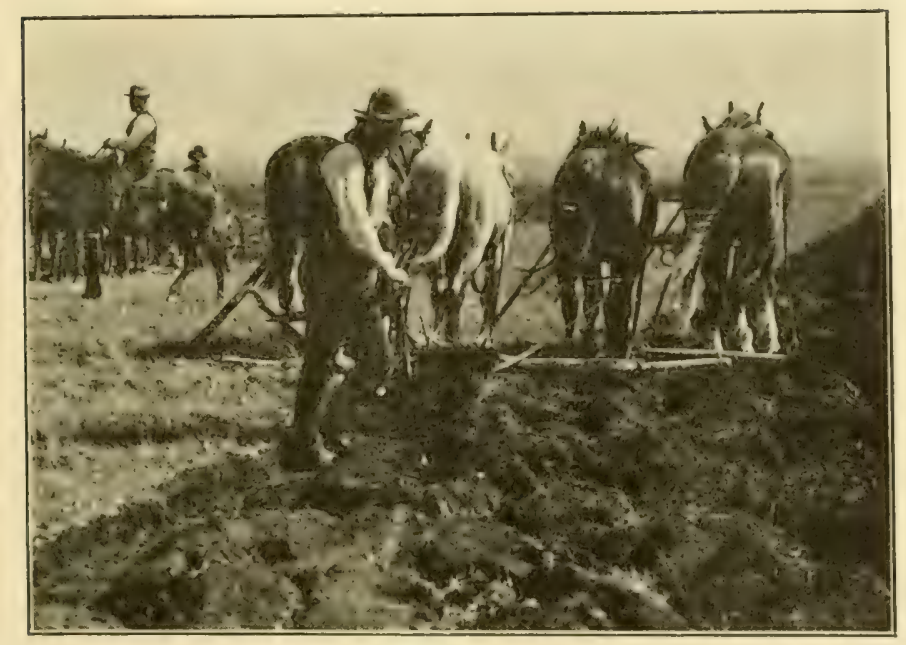

Plowing With a Four-Horse Team on a Ranch in OKIaAmoma.

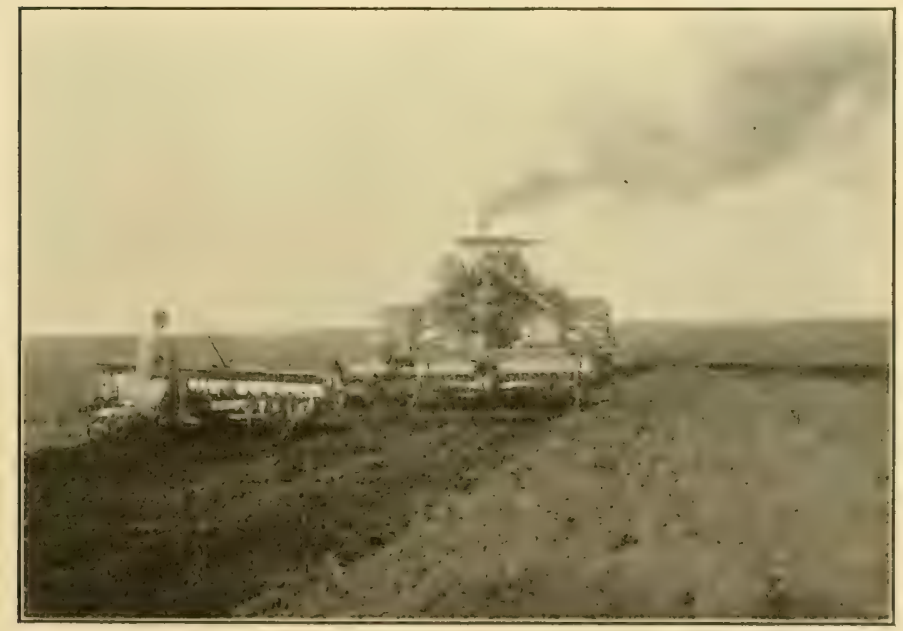

Steam Plow and Seeder at Work on a Ranch in California. 


\section{AN INTRODERTION TO AGISTELTERE}

grives depth of soil so that there is ample living room, a large fording arra, an abundant storage for moisture, and arailable plant food. A lumpy soil and a hard orust covering the surface will keeplout the air, which is neesessary to soil activitios. Me leamed in the last chaptep (Sec. 18) that a fine soil gives more room for water amongr the particles of earth. In a fine soil this moisture can circulate better and tillage is a great help to ceretain very important soil organisms that make plant food arailitble, which we have not spokem about yet.

23. Preparation of the Seed Bed.-- foreds especially repuire a good soil for their growth, and tillage helps to prepare the propere seed bed. In the spring the soil is tumed orer so that the sum may warm it and is harrowed down into a fine smooth bed. The soil must be fine and loose, so that when the sered sprouts its delicate stems and rootlets may easily get through the soil and close to the soil particles. In some cases it is desirable to till the gromel just before the young shoots come up), so as to break the crust for them.

24. Regulation of Moisture.-Tillace helpss to recrulate the amount and moverment of moisture in the soil. When a few inches of the surface soil have been loosened, the rain water will sink in instead of washing off the land and being wasted.

This loose soil on top) makes what is called a surface muleh. In loose earth the particles of soil are more separated, so that there is more syace betweren them. Water does not readily pass through dry, loose soil by eapillarity, for, in the loose soil, the capillary pores ares broken uj). So this surfare muleh prevents the ground 
from drying out by making it impossible for the decperlying moisture to reach the surface.

When possible, the land should be tilled after each rain to keep the soil loose. By repeating this so that two or three inches of soil on top are always loose and dry, the farmer can keep most crops alive even in the driest weather. Tillage, then, accomplishes two important things: it carries rain water to the roots, and it prevents moisture stored deep in the soil from roming to the surface and evaporating.

25. Other Uses. - Soil is often tilled to cover barnyard manure and green manures, that is, green crops intended to be mixed with the soil to form humus. These are all plowed under so that they may decay and enrich the soil. They provide valuable food for the plant and in many ways improve the physical condition of the soil.

Still another use of tillage, and one that farmers count of much importance, is the destruction of weeds. The plow, or cultivator, uprooting them, hinders their growth. The best time to kill weeds is just as they come up, and before they are large enough to do any damage.

26. A Risk in Tilling.-In tilling between the rows of growing crops, great care must be used not to disturb the roots. Corn and some other plants send their roots out between the rows and near the surface of the ground. While tillage is very beneficial to the corn crop, which needs plenty of moisture, the farmer must watch that the cultivator does not go deep enough to break the fine roots. 
27. Importance of Good Tillage.-It is rviclent that. one of the most important things for the farmere to consider is the tillage of his soil. Even thomeh there may be plenty of plant food in the soil and plenty of water and sumshine, all these will not produce a geond ("rop) monses the texture of the soil is right. This is obtainerl chiefly by enod tillage. Moreover, a lack of the prenere amount of plant food, water, and air may be latredy remedied by tillage.

r. Raise plants in two boxes of soil: let the soil in one box be undisturbed and keep) the other thoromenty tilled. Fen whether one plant thrives better than the other.

2. Ratise at plant in a porous flowerpot and another in at tin can. Otherwise treat them just alike and note whether one thrives better than the other.

In 1731 Jethro Tull, in England, diserevered the value of tilling the soil. He learned that he eould geet better erops by thorough tillage. Knowing that the plants got. more food in this way, he thought that plants took in fine particles of soil as food. He wrote a book to show the value of tilling the soil for this purpore, and though his reasons were wrong he did much grood by showing farmers everywhere the value of tillage.

28. Tillage Implements-The Plow.-The most inportant tools used in tillage are the flow, harrow, planker, roller, rake, and hoe.

The plow is the most important tool. Its work lays the foundation for the use of the other tillage tools. It consists of a stamdard to which the other parts are attached, the beam, by which it is drawn: the share, which cuts the furrow slice at the bottom; the mold board, 
which turns and pulverizes the furrow slice; the landside, and the handles, by which the plow is held. I3esides these chief parts are the clevis, by which the plow is attached to the doubletree, and the coulter, which is sometimes used to cut the furrow slice. A

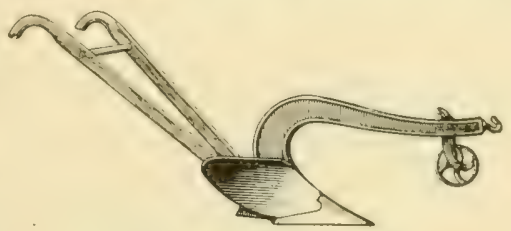

(1) P.). jointer is frecuently attached to the beam to cut and turn the sod when plowing sod land.

The plow cuts the furrow in slices and turns it over. At the same time it breaks up the soil, or pulverizes it. This is acemplished by grinding the different layers of soil upon each other. You ean see how this is done by bending up the corners of a pamphlet and letting the leaves slip on each other. In a similar way the plow causes the soil to slip and become fine.

In order that plowing may pulverize the soil successfully, the soil must be in just the right condition of dampness. If it is too wet, the particles will stick together. If too dry, it will crumble where the plow euts it and the rest of the furrow slice will not be broken up.

The furrow slice should not be turned over entirely, but left on its edge. In this way the weather ean act on it (Nee. 23). This is especially important in fall plowing. Fields are plowed in the fall chiefly in order to let the weather aet on the soil during the fall and winter.

29. Harrows, Plankers, and Rollers. - After the field is plowed, the clods of earth must be broken up and a 
fine, loose surface made. IIarrows, cither disk, spike, or tooth, are used for this purpose. The disk harrow is lesert on hard land and on sod to cut up the sod

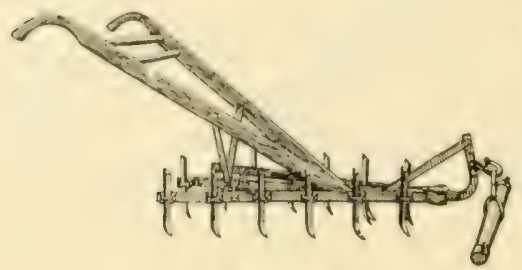

A Hanrow. and loosen the soil from the grass roots. A fine-toothed harrow, or sometimes a planker or roller, is used for the final work of preparing the ground for the seed.

The planker is made by bolting together three or four planks like clapboards in such a way as to leave a rough surface. This further breaks the clods and smooths the ground. The planker, however, is likely to

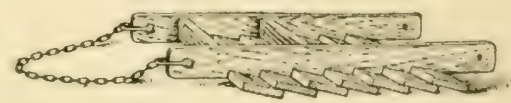

A PLANKEn.

destroy the surface muleh. If this is done, the ground must soon be harrowed again to prevent the formation of a hard crust and the drving of the land.

A roller is sometimes used to break the chods and to pack, or compact, the soil about the seeds. The soil soon dries out after a roller has been used, so that it should be followed by a light harrow to produce a surface mulch.

(io to a place where plows and other farm mathinery are sold and examine all kinds of tillatge implements.

It is time and labor weell syent to take proper eare of farming tools. The soril should be eleaned off from 
plowshares and cultivator teeth and the machines put under cover when not in use. This is especially true of hoes, rakes, shovels, and spades which should never be allowed to get rusty.

30. Dry Farming.-A new or improved method of agriculture, called dry farming, has recently been used in some parts of the West, notably in western Kansas, Nebraska, eastern Colorado, New Mexico, Arizona, and Texas. The method aims to save what little rainfall there is. This is done by continually stirring the ground, so that the rains will be quickly absorbed and evaporation prevented. After one crop is removed, the land is immediately worked again. Sometimes it is tilled all of one year to store up moisture so that a crop can be grown the following year. This gives one crop in two years. With more rainfall two crops are grown in three years, and with still more, a crop is grown every year, but in each case the same principles are applied.

By these methods good crops are being raised every year where formerly a good crop was an exception. It was previously thought that an annual rainfall of about thirty inches was necessary, but farmers are producing grood crops by dry farming with only ten, twelve, or fifteen inches of rain annually. Vast areas of dry lands in our country that have been considered useless, exerpt for grazing, may now be made profitable by these new methods.

Seeds from foreign countries, especially adapted to dry climate, are selected for these regions. Among them are macaroni wheat, Turkestan alfalfa, dwarf Milo maize, Swodish oats, corn, barley, and potatoes. $\mathrm{U}_{p}$ to 
the present, the main produce of dry farms has been wheat.

\section{SUMMARY}

Tilling the soil is working it to rhange its texture.-(ieneral tillage is for the purpose of producing a grood seed bed.-Intertillage is for the purpese of supplying air in the soil, conserving moisture, and destroying weeds.-Tilling makes the soil finer: increases the surface of the soil particles, thus making a larger feeding ground for the plants; increases the water-holding catpacity of the soil by making a surface muleh which prevents evaporation; kills or hinders the growth of weeds.

The tools used for tillage are the plow, disk harrow, toothed harrow, cultivator, planker and roller, rake, hoe, and other hand tools. - Harrows are used to pulverize the soil.- l'lankers and rollers are used to crush clods, and to make the soil more compact and bring it in contact with the seeds.-For suecessful plowing the soil should be just moist enough to turn in a furrow. -The main objects of plowing are to overturn and break the soil and to plow under manures. - Fall plowing is to expose the soil to the action of the weather.

The methods of dry farming aim to preserve moisture in very dry soils so that good erops can be grown there.

\section{QUESTIONS AND PROBLEMS}

I. Why do we cultivate and hoe corn?

2. Why does the soil in a flowerpot often produce so much better plants than the same amount of soil in the field?"

3. Why are weeds bad for crops?

4. Why does the garden raise larger erops than the field?

5. Why should plows, harrows, and tools be housed?

6. If soil is cultivated five inches deep, how many cubic feet to the acre are cultivated? If seven inches deep, how many cubic feet? If nine inches deep, how many eubie feet? 
7. How many acres are there in a piece of land 32 rods long by 20 rods wide?

8. If land of that measurement is plowed back and forth with furrows nine inches wide, how far will a man travel to plow it?

9. If by extra cultivation a man can raise 100 bushels of potatoes more an acre, how many days' work would thus be paid for, allowing \$3 per day for man and team, if the potatoes bring 25 cents per bushel?

ro. How may any one who has a garden apply the lesson of dry farming?

Ir. (iive two reasons for maintaining a surface mulch.

12. In what way may tillage injure a crop? 


\section{CHAPTER V}

\section{ENRICHING 'TIIE SOIL}

3r. Elements and Compounds.-There are three foods which are necessary to the growth of plants which farmers often have to supply to the soil. These are nitrogen, phosphorus, and potassium. These substanees are called elements. An element, aceording to chemistry, is a substance emposed of only one kind of matter. There are about eighty distinet and different elements in the world. Most substances that we see around us are mate up of several elements combined. Two or more dements combined make what is called a compoumd. A rompound ean be separated into two or more different kinds of matter that may have no resemblance whatevere to the original compound. The elements on which the plant feeds enter the plant not as elements, hut united vith something else in the form of eompoumds. There are, in fact, about thirtern different elements that are used by plants as food. The soil generally contains an abundant supply of all but the three mentioned above. In addition to these three, lime, magnesium, and iron are indispensable to plant growth.

Nitrogen.-Nitrogen, being an element, camnot be separated into parts that are any thing but the nitrogen itself. 
It is a gas. It forms four fifths of the air we breathe; the other one fifth is mostly oxygen, as you have probably learned from your physiology text-book. Nitrogen will not burn. When available for the plant, it is combined with oxygen and a metal, as sodium or potassium. Such a substance is ealled a nitrate, as nitrate of sodium or nitrate of potassium. The root hairs, however, take from the solution of sodium nitrate the nitric acid and leave the sodium.

Phosphorus.-You have all heard of phosphorus, for it is commonly used in the making of matches. It is a scarcer element than nitrogen, though more familiar to us. Its chief characteristic is that it takes fire readily. Phosphorus may be obtained from bones, in which it is combined with oxygen and a metal called calcium, an important element in lime. The combination of phosphorus, oxygen, and calcium makes a substance called calcium phosphate, or phosphate of lime. Shells of lobsters, crawfish, and like animals contain calcium phosphate in large quantities. Phosphorus is found also in a mineral called apatite, and in guano. There are large deposits of phosphate rock in Florida, South Carolina, and Tennessee.

Potassium.-Potassium is a silvery white metal, soft as wax and light enough to float on water. It has to be kept in air-tight bottles or under kerosene to prevent its absorbing oxygen out of the air or water. Potassium is found combined with oxygen and nitrogen in a salt called nitrate of potassium, or saltpeter. In the soil it exists as sulphates and chlorides and in other forms in which it can be disiolved and used by plants. Feldspar 


\section{AN INTROTOTOTION TO AGRIOTITTRE}

is one of the chief sourees of potassium. It is found also in wood ashes in the form of potassium carbonate or potash. The potash ${ }^{1}$ needed for plants ean be obtained from manures and from wood ashes by pouring water through a barrel of such ashes or by plowing under the manure or ashes. The water will take the potash out of the ashes. The chief souree of potash used in commercial fertilizers is found in mines in Cermany, where it is mined like salt.

With a tenpenny nail punch some holes through the bottom of a tin can. Put a piece of eloth in the bottom of the ean and then fill the ean with ashes. Pour a pint of hot water through the ashes, eatehing that which drips through in some sort of vessel. Pour the same water through two or three times. Fraporate the lye so obtained, either in the sun or on a stove. That which remains is crude potash, a compound of potassium, carbon, and oxygen.

\section{The Source of the Three Kinds of Plant Foods. -} Potassium gets into the soil chiefly from the feldspar in granite rocks. The action of the weather breaks up the feldspar, and the potash is set free or made available. Growing plants take up this potash. When the plants decay or are burned, the remains or ashes contain the potash.

The deeay of rocks is the original souree also of phosphorus. This ehanges in the proesess of decay, and phosphoric acid results. Plants foed on this, and animals feeding on the plants take in the phosphorie acid, which

1 The potash referred to in tables and statements giving the amount of potash in soils and plants is another compoumel, viz., potassium and oxygen. 
combines with other sulnstances to make bones. By the deeay of plants or of bones the plant food is again set free in the soil. And so the same material goes round and round. As the scientist says, "It performs the cycle of nature."

Nitrogen for the plant comes from the air (Sec. 31) and from the humus of the soil. Nitrogen in the air among the soil particles is absorbed and stored up in microseopic plant growths called bacteria. These bacteria grow in little bunches, or tubercles, upon the roots of certain plants. From these tubereles the nitrogen can be released to feed other plants, as will be explained in Chapter VI (Sec. 42).

Other bacteria not living on the roots of plants absorb nitrogen from the soil air. They help the deeay of plant growths and the humus of the soil, and from this decay ammonia and nitrates are formed, making the needed plant food. These free-living bacteria are indispensable agents in the soil. As an instance of the work they do, we mention two fields at Rothamsted, England, which had run wild for twenty-five years. In one field the amount of nitrogen taken from the soil and air and left in the soil was forty-five pounds per acre per year; in the other field it was ninety-eight pounds. The greater amount of nitrogen in the second ficld was probably due to an abundant supply of carbonate of lime or limestone.

33. How These Foods Get Into the Plant.--The plant foods get into the plant and pass through it by a process called osmosis. The foods are dissolved in soil water, which we then call the soil solution, and in the solution 


\section{It AN INTROH)ECTION TO AGRICLLTURE}

pass from the soil into the tiny root hairs of the plant. As fast as the plant makes use of this food, more of it is absorberl from the soil solution by the roots.

In the minute eells of which these root hairs are made, there is something called protoplasm, which is the living part of the plant. This protoplasm in the root hairs, by the process called osmosis, draws in this soil solution, which passes into the cells of the root and mores up through the stem and branches, and feeds all the

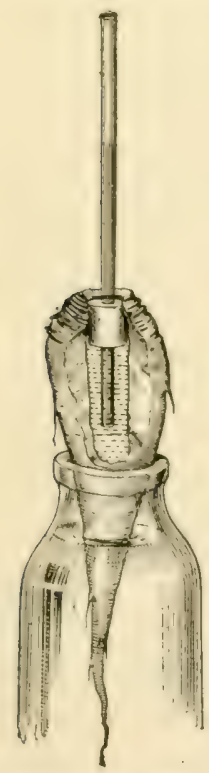

WXPEIMENT SHOWING U.Mosis. tissues of the plant. Thus by a constantly moving current the plant gets its nourishment.

You can surely understand now how important it is that the soil solution should be in just the right condition to enter the plant properly (Sec. 4). You know also that the soil must be fine so that there may be a great amount of surface to hold soil water (See. 18).

To illustrate osmosis, carefully remove a small piece of the shell from one end of an egg and place the egg in water. The water will pass through the unbroken membrane of the egg, causing the membrane to bulge out of the shell. Another good experiment is to take a cork (rubber preferred) with a hole in it. Into the hole fit a glass tube the size of a lead pencil and a foot or more long. Bore a hole into the end of a carrot large enough to receive the cork and two inches or more deep. Nearly fill the hole in the carrot with sugar 
sirup and insert the cork so that it fits snugly. Place the carrot in a bottle of water. The sirup will pass out through the cells of the carrot and the water will pass in faster than the sirup passes out, so the water and sirup will be pushed up the tube.

\section{The Use to the Plant of Each Kind of Food.-} It is still uncertain just what each of the important plant foods, potassium, phosphorus, and nitrogen, does for the plant. Some things, however, have been determined. We know that the absence of any one of these necessary to the development of a certain crop will result in a weak, unsatisfactory growth.

If there is not sufficient potassium in the plant food, the plant will grow slowly or stop growing. The addition of certain substances containing potassium to the soil will again start the plant's activities. Potassium seems especially necessary in producing vigorous fruit plants and potatoes.

One thousand pounds of winter wheat contain an average of about five pounds of potash, which is a compound of potassium and oxygen. The same quantity of straw contains about six pounds of potash. This is a heavy drain on the supply in the soil and all the potash in the waste straw should be put back into the soil. Farmers formerly got rid of the straw that was left after the wheat was threshed by burning it. After some years of this practice, the growing erops would not hold up their stalks long enough to allow the grain to ripen. The farmers then said that the land was becoming so rich that it grew wheat too large to stand up. They have since learned better. The soil needed more potash to make the stalks stronger. This potash can be put 


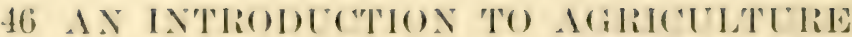

into the soil hy plowing into it the straw left after thesesing. This straw dereass, and finally the potash gets into the soil solution in a form that the plants an feel on.

Phosphorts makes the plant vigorous and hardy. A good supply is neederl especiatly in the early stages of the plant's life. It helps to make the sereds plumpe and good. Grains eontain even more phosphorie arid than potash. Some of the phospherus in the grain is discarded when fine flour is made, and for this reason fine flour is not so complete a food for man as whole flour.

An abundant supply of nitrogen results in the production of large, healthy leaves and stallis. Henee nitrogen is expecially valuable for the plants that are raised for their leaves and stalki, as lettuee, asparagus, and hay, and for those that must make a vigorous growth before setting fruit or soest. Wheat and other grains take much nitrogen from the soil. One thousand prounds of grain eontain sixteen to twenty-four pounds of nitrogen. Beans, peas, and such plants contain much nitrogen; but they may sometimes leave more nitrogen in the soil than they find there, as we shall learn in the next chapter.

35. Barnyard Manure.-An important question for the farmer is how he shall provide the food needed by his growing erops. (lose at hand he has a most valuable soures of plant food. Itis barnyard manure contains material which the plant can easily use. Each thensand pounds of manture contain on an arerage five promels rach of nitrogen and potash, and three and one thirel pounds of phosphoric acid.

The manure may be spread over the ground or it 
may be plowed into the soil. As it deeays, it makes the humus which is so necessary to a rich soil. The texture

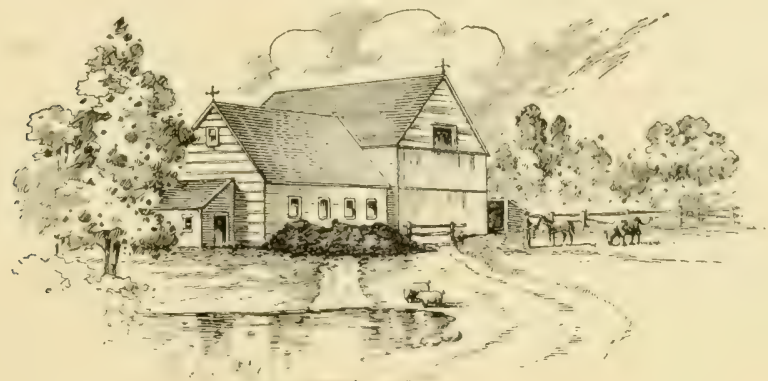

Care of Barnyand Manure-Wrong way.

of the soil and its capacity to hold moisture are improved by this means (Sec. 18).

It is asserted by some authorities that the manure "produced annually by each horse or mule is worth $\$ 27$,

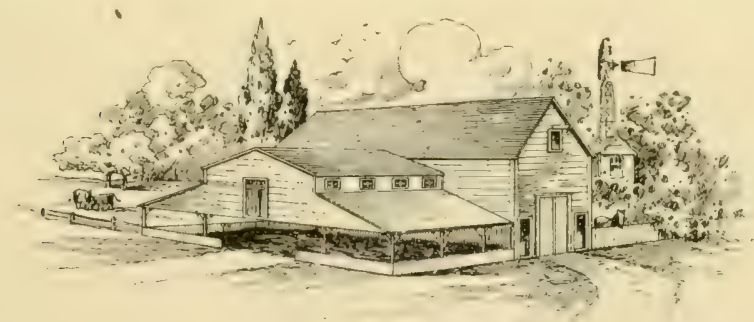

Care of Barniard Manure-Right way.

by each head of eattle $\$ 19$, by each hog $\$ 12$, and by each sheep \$2." Much of the value, however, is wasted by the slipshod way in which many farmers take care of 
the manure. By exposure to rain more than half its value may be lost. To preserve its full value, manure should be kept moist, eompanet, and under cover, or eloce it should immediately be spreat on the land.

36. Other Ways of Enriching the Soil.-Cirowing crops and stubble when plowed under add some of the needed food elements to the soil and improve the texture of the soil. We have read how the straw from grains returns potash to the soil when plowed in (see. 34). Stubble must always be plowed under. The question of plowing under green, unharvested crops, however, is one that needs the farmer's best judgment. There is some danger that the addition of such material may make the soil too dry and perhaps leave it too loose for seeding. This is especially true with light soils, and a great mass of green material should not be plowed under; with heavy soils the danger is much less. In ease of a droughr, such plowed-under crops will not decay properly so as to make good humus. The time to plow under green erops or "green manures" is very important and is determined largely by seasonal conditions and the crop that is to follow.

37. Commercial Fertilizers. - Another resouree of the farmer for enriching the soil is eommereial fertilizers. If can buy, by the bag, material containing nitrogen, phosphorus, and potassium in suitable form for use in the soil. In many states it is recpuired by law that these commereial fertilizers shall be analyzed under state supervision and their sale lieensed by the proper anthorities. The bags in which they are packed must bear a printed statement of the eomposition of the fertilizere 
Thus, if the farmer knows the particular elements needed by the crop he is growing, he ean choose the kind of fertilizer that contains those elements.

In some localities it is possible to buy wood ashes. These contain potash and phosphoric acid, and are firstclass fertilizer when these foods are needed. Ashes do not supply any nitrogen, however.

It is cheaper, of course, for the farmer to use as fertilizer the manure produced on the farm. This also does more good to the soil. But it is sometimes desirable to supplement it with commercial fertilizers. The farmer can rely on them to give the plant quickly the desired food elements.

If you have an opportunity to work in a garden or field, experiment with small patches of land, putting no manure on one patch, cow manure on another, horse manure on another, wood ashes on a fourth, and some commereial fertilizer on a fifth. Sturly carefully the effect on the crops grown on the different patches.

38. Amendments. - It remains to mention another class of dressings which are supplied to the land chicfly because they improve the texture of the soil or improve the chemical condition. Such are called amendments. The chief of these is lime. Lime is added to clay soil to make it less sticky, and to sandy soil to make it more compact. Lime also counteracts in soils the effect of acids, which otherwise might harm the erop, and promotes chemical activities which result in making plant food available. It is most likely to be needed by clover and alfalfa. If these crops grow well on the soil, lime is not likely to benefit other crops. 


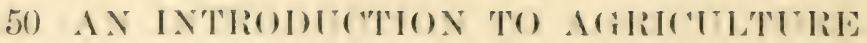

Common salt is another sulstanes often used on soils. It helps to sed free the phosphates in the soil so that the plant ran use them. The best results are seeured in dry seasons, because the addition of a little salt aids in the movement of the soil water so that more bercomes available to plants. Salt should be used sparingly, and not at all om a potato or a tobaceo crop. It will pay better to spend the money for commercial fertilizers.

Gypsum or "land plaster" is also a common amendmont. (Others are marl, muck, and chalk.

In winter, experiments may be performed by planting seeds in several boxes or flowerpots, filling them with sand, mixtures of sand and garden soil, sand and manure in various proportions, sand and leaf mold, and sand with various commereial fertilizers added. Keep a reerord of the kind of soil in each box or flowerpot. Watch the growth of the plants and decide which are the better soils.

39. Nitrification.-Wre have said that the various compoumbs which contain the elements of plant food must be ehanged before the plant can absorth this food. such changes are constantly going on in the soil. The proeess by which the different eompounds containing nitrogen are changed is called nitrification. Lime added to the soil often helps this process.

Nitrification is the work of minute organisms which are active under eertain conditions. It consists in the union of nitrogen compounds with oxyeren, and is the final step in the preparation of soil nitrogen for the use of plants. To have the conditions right for this preparation of nitrogen for the plant, there must be in the soil 
air, moisture, sufficient warmth, and the absence of strong sunlight. There must be food for the minute organisms; and the soil must contain some compound, such as calcium carbonate (limestone), with which the nitrogen may unite.

\section{SUMMARY}

Everything in the world is made up from about eighty different elements, thirteen of which go to make up plants and animals. The f:urmer is concerned only with these thirteen elements, and he has frequently to provide for three-nitrogen, phosphorus, and potassium.-Nitrogen is a gas and constitutes four fifths of the air.-Phosphorus is the substance used on the ends of matches. It is extracted from bones and other substances.Potassium is found in certain rocks. It is one of the elements in potash, and is obtained from wood ashes.

The three chief plant foods are compounds of nitrogen, phosphorus, and potassium.-The chief nitrogen compounds atre nitric acid, ammonia, sulphate of ammonia, nitrate of potassium, and nitrate of sodium. - The chief compound of phosphorus is calcium phosphate.-The chief potassium compounds are nitrate of potassium, sodium nitrate, potassium chlorid, and sulphate and muriate of potash.

All these compounds, except ammonia and nitric acid, are ralled salts and may be found in solution in the soil water. They are derived from the decay of rocks and bones, from wood ashes, and from manures or fertilizers.- These salts reach the plant through its roots. A good supply of the compounds of nitrogen, phosphorus, and potassium is necessary to the healthy growth of plants.

The most important enrichment for the soil is barnyard manure. It contains all three of the plant foods and also benefits the land by improving its texture.- (ireen crops and plowedunder stubble enrich the land and improve its texture.-C'ommercial fertilizers contain plint food in a soluble form and so 
produce quick results. - Nitrifeation is the changer that takes place in the soil, by which locked-up nitrogen is made availathle for the use of the plant.

\section{QUESTIONS AND PROBLEMS}

x. What is an element?

2. What is a compound?

3. How many elements make up the earth?

4. How many elements does the plant use?

5. Which cloments must the farmer often supply?

6. By what process does the plant geet its food from the soil?

7. Name four kinds of plants that are raised for their leaves or stalks. What clenent is epecrally valuable for surh plants"?

8. Is it a good pratice to rake leaves into the roud and burn them?

9. Why are soils derived from granite roeks more durable than those from limestone?

Io. One thousand pounds of tobaeco take from the soil t.2 pounds of nitrogen, 5 pounds of phosphoric atede and 57 poumls of potash. If the nitrogen is worth 15 cents a pound, and each of the others 5 cents a pound, what is the total value of the substances taken from the soil?

II. ()ne thousand pounds of corn take from the soil $1 \mathrm{~s}$ pounds of nitrogen, 17 pounds of phosphorie acid, and 4 pounds of potash. What does the corn cost the soil in plant fout or money cost, based on $\$ 10$ ?

12. If 1,000 pounds of wheat remove 52 pounds of potash from the soil, how much will 40 bushels to the acre remove per acre?

13. If the straw weighs one and one half times as much ats the grain and 1,000 pounds of straw remove 6.3 pounds of potash, how much will the straw of 40 bushels remove?

4. The corresponding amount of phosphoric aceid is 7.9 pounds for the grain and 2.2 promels for the straw per 1,000 
pounds. How much phosphoric acid will be removed by the 40 bushels of wheat and the straw?

15. The corresponding amount of nitrogen is 20.8 pounds for 1,000 pounds of grain and 4.8 for 1,000 pounds of straw. How much nitrogen will be removed by 40 bushels of grain and its straw or Problem 13?

16. If a ton of barnyard manure contains 10 pounds of nitrogen, 6 pounds of phosphoric acid, and 9 pounds of potash, how many tons per acre should be used to make up for what the wheat removes? It may be necessary to multiply the result by 5 because only part, say, one fifth, of the plant food is available the first season. Ten to 30 tons is considered the proper amount by different authorities.

17. What is an amendment?

18. What is meant by nitrification? 


\section{CHAPTER VI}

\section{LEGLMINOLA TIANTA-ROTATION OF CROTS}

40. Clover and Its Relatives. - One of the most useful crops that can be grown on the farm is clover. This may serm surprising to you because clover supplies no food for man. Its usefulness comsists in its improvement of the soil for the growth of other crops in addition to its feeding value for farm stock. A great many years ago it was known that a (rop of clover improved the soil in which it was grown, but only recently was the reason for this discovered.

The clover belongs to a family of plants called leguminous plants, or legumes. These plants have very irregular flowers generally shaped somewhat like butterflies, and seeds in a long pod or lecume. The leaves are eompound, that is, they are made up of three or more leaflets like the clover and locust. The family is ealled also the pulse family. To this family belong, besides the clover, the locust tree, peas, peanuts, beans, veteh, alfalfa, and some other plants.

Make a collection of the flowers of the clover, peat, bean, alfalfat, and lowest and note the similarity. Notice that the leaves of all such plants are compound. 
4I. Fixation of Nitrogen.-One reason that clover is so useful to the soil is because it take's nitrogen from the soil air and makes it available for the nourishment of other plants. The proeess of getting nitrogen from the air and leaving it in the soil is called fixation of nitrogen. Many books have been written on the subject, and many experiments have been made with the object of finding other ways of fixing nitrogen from the air. It can be done by the aid of electricity.

42. Legumes as Nitrogen Gatherers.- ('lover and other legumes have a very special way of making nitrogen available as plant food. One might expect that, since nitrogen is in the air, all plants could get it through their leaves; but most, if not all, plants are unable to do this.

The leguminous plants have on their roots little bunches or tubercles. These tubercles contain minute, simple plants called bacteria. These bacteria can take ni-

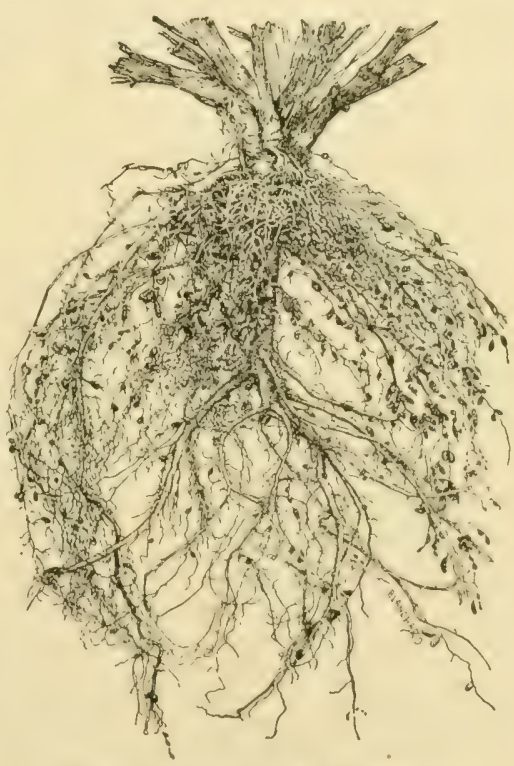

Ren Cuovir RoOTt SiHowing TUBRERES. trogen gas from the air and eompound it with other things, making nitrates, which furnish food for the plants 
on which the bacteria live. When the roots decay, the nitrogen is left in the soil, and other plants oan then use it (s'ece. 32). Moreover, the bacteria maty make more nitrates than ean be used by the plants on which they grow. The extra suplyly goes into the soil.

Sometimes the exems from which the clover bacteria srow are not found in the soil, and the clover or other leguminous plant does not grow woll. In such case the erems can be supplied by adding, at the time of planting the seods, soil which eontains the germs, olstained from land where clover has been errown sueressfully. - This process of adding hacteria is called inoculation.

Carefully dig up a bunch of clover and wash away the soil from the roots so that you can see the tubercles. It will not do to pull up the plants, as the tubereles will then be left in the ground.

These bacteria, of which there are many kinds, are similar to the haxeteria that you may have learned about. in your physology lesions. Fementation and derays of various kinds are due to bacteria.

43. Other Uses of Legumes.-Legrminoms plants benefit the soil in another way. They are derp ferelers, that is, their roots ero far down into the soil. Thus they may feed on material that could not be reached by other plants. When their deep-reaching roots decay, they leave the ground porous for the entrance of water, air, and the roots of other plants.

C'lover erops are frepuently plowed under, and in this way the plant food which they contain is mate available for other plants and humus is adeled to the soil. 
Leguminous plants have large leaves and stems that are useful for forage. Alfalfa is hecoming especially popular hecause it produces a great quantity of hay; several erops may be taken off in one season (seec. 102). The seeds produced by eertain leguminous plants are especially nutritious as food for man and beast. Beans, peas, and peanuts, for example, have been used for food in all ages.

44. Rotation of Crops. - It is evident from the above how advantageous it is to alternate leguminous plants with other crops. There are other reasons, however, why the wise farmer does not raise the same kind of crop year after year on a piece of land. He plans a series of three or four different crops which he grows in succession on each field. This alternation of a series of crops on the same piece of land is ealled rotation of erops.

45. Rotation is a Weapon Against Pests. - An important reason why rotation of crops is not only expedient but necessary is this-many plants are attacked by their own particular kind of insects or fungous diseases. After a crop has been grown on a piece of land for some time, the soil is filled with the eggs or larvip of the insect pest or with the germs of the fungus. Therefore it becomes necessary for the farmer to starve out these pests by changing the crop to one on which they do not feed. For example, it beemes almost impossible to raise summer squash in eertain gardens because of the brown squash bug. If squash is not planted there for a few years the bugs go elsewhere and a few crops of squash ean be grown before the bugs return. Potato seal) lives in the soil, and if onee estab- 


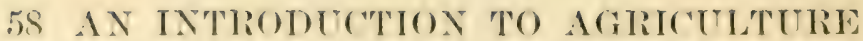

lisherl and not eliminated by rotation it continues to infest successive crops of potatoes.

46. Rotation Destroys Weeds. - If cropss of grain which have no summer tillage are raised continuously, the ground beromes overrum with weeds. If a (rop) of grain is followerl by corn or potatoes or other tilled crop, the soil is stirred and the weeds are thus destroyed. Different erops recquire different treatment, and this varying treatment is good for the soil. Potatoes and other plants that have food produets on their roots have to be dug out of the ground, and this digging leaves the soil in good condition for the next erop).

Ind may be learned by observing the practices of neighboring farmers and by noticing that flowering plants grow murh better after being transplanted. Note, also, the difference in vigor of crops on new land and on old land.

\section{Rotation Practically Enlarges the Farm.-Differ-} ent plants have different feeding habits. Some plants feed near the surface of the ground and exhaust the food there, while others send their roots down and feed in an entirely different part of the soil. This practically enlarges the farm on which crops of different feeding habits are rotated. The roots of elover often go down several feet in sandy soil. Wheat possesses an extensive root system, while barley is shallow rooted. By dexp fereding not only is the surface soil relieved but plant food is also brought up and left near the top for surface feeders to use later. Furthermore, some ropls mature early while others feed during the entire seasom. Farly peas, for example, are errown in July, while com con- 
tinues to grow till October. The farmer can take advantage of these conditions in the rotation of his erops. Winter wheat planted in October will grow through the late fall and early in spring. After it is cut in midsummer there is, in southern latitudes, still time for a short-time erop, and thus the land is used throughout the season. Oats and barley mature about three months after sowing.

\section{Rotation Regulates the Food Supply in the Soil.- -} When one crop is raised in the same soil for a number of years the land tends to wear out. This one crop depletes the soil of certain kinds of plant food so that after a while the crop will not grow well. But the same soil can still supply sufficient food for a different crop). This is not because different plants use different food materials, for it has been found that all plants use practically the same kinds of foods. It is because different plants use different proportions of the same foods. For example, 1,000 pounds of tolaceo remove from the soil 45 pounds of nitrogen, while the same amount of Indian corn removes only about 25 pounds. The tobaceo removes 50 pounds of potash, while the corn requires only 10 pounds. On the other hand, 1,000 pounds of clover may actually add to the soil one half as much nitrogen as it removed and take out only 22 pounds of potash. From this it will be seen that elover is a good crop for land defieient in nitrogen, and Indian corn for land from which the supply of potash has been largely drawn.

The following table shows the number of pounds (to the nearest whole number) of each of the principal 
plant fouls taken out by 1,000 pommlis of the given

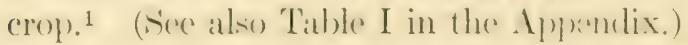

\begin{tabular}{|c|c|c|c|}
\hline & Nitrogen & Phosphoric Acid & Potash \\
\hline Wheat (grain and straw)...... & 34 & 11 & 14 \\
\hline Oats (grain and straw)....... & 32 & 11 & 26 \\
\hline Indian corn ................ & 25 & 9 & 10 \\
\hline Clover $^{2} \ldots \ldots \ldots \ldots \ldots$ & 20 & $4 \frac{1}{2}$. & 22 \\
\hline Tobacco...... & 45 & 5 & 50 \\
\hline
\end{tabular}

49. The Norfolk System of Rotation. - It has taken many years of observation and study to determine what (rops should be userl in a series for rotation. The first system to gain attention in America, and one still much userl, consists of roots (turnips), barley, clover, wheat. This is called the Norfolk system because it originated in Norfolk County in England. It is of more importance for having callerl attention to ('rop) rotation than it is for the actual alternation of erops involved. Tumips, which are deep foeders, are followed by barley, which feeds near the surface. Both of these crops remove nitrogen, so colover (a deep) foreler) is next grown in oreler to renew the supply of nitrogen. The system is, of course, raried to suit local conditions. In the Inited States corn and potatoes take the place of fumips. When stock is kept on the farm the Norfolk Fystem may be changed to allow erops of mixed grass and clover for

${ }^{1}$ It should lye understool that these numbers are only approximate for the reason that the proportion of straw or stalks to the grain or secels varies. They illustrate the point, however.

2. Is before stated, although the clover contains a large amount of nitrogen, it gets much of it from the air. 
two or three years. Or, if not much stock is kept, sugar beets, barley, clover, and wheat may be the series. Oats may be grown instead of barley, and rye in place of wheat. In certain states corn is used in the series for one or trio years. In Ohio, clover, potatoes, and winter wheat are sometimes grown. In Massachusetts, potatoes and corn are grown for two years and grass and clover for three years. A common rotation on dairy farms is corn, oats, wheat, clover, and timothy for two years. The rotations that are employed in various regions and under various circumstanes are almost without number.

\section{SUMMARY}

Clover is one of the most useful erops on the farm. It belongs to the family of leguminous plants, which includes also alfalfa, peas, beans, and vetch.

Leguminous plants all have the power of fixing the nitrogen of the air and making it available for plant food.-These plants are known by a peculiar butterfly-shaped flower, seeds in a long pod, and compound leaves. - They are deep feeder's and so loosen the soil.-They have many leaves, which furnish much forage. -They also produce many seeds, which are a valuathle food for man and beast.

By rotation of erops is meant the changing of the erop from year to year on a given piece of land.-Rotation of crops is desirable for the following reasons:

Different crops are infested by different insects and associated with different weeds;

Different crops take different amounts of plant food;

Different crops send their roots down to different depths;

Crops vary in their feeding time, some maturing carlier in the season and some later; 


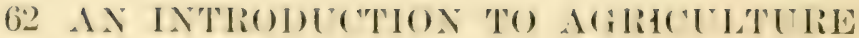

Different erops need different treatment.

The supply of humus can be mantained in the soil.

\section{QUESTIONS}

x. What is a leguminous plant?

2. What are the characteristic's of its leaves, seeds, and flowers?

3. Cive three reasons why legumes are useful to the farmer.

4. Would gou plow under the whole chover erop or only the stubble?

5. How does the alfalfa crop differ from the timothy?

6. What is meant by rotation of erops?

7. Give five reasons why rotation should be prateded.

8. (iive one series of crops for rotation not given in the text and explain its advantages.

9. What should govern the farmer in deciding what erops he will raise?

Io. Would you follow a crop of oats with a crop of wheat? Why?

II. Why is it bad praceties to raise tobatere on the same piece of land year after year?

2. What system of rotation do the farmers in your neighborhood use? Ask them, and ask them why. 


\section{CHAPTER VII}

\section{PLANT FOOD AND HOW IT IS USED}

50. The Factory of Nature.-The plant, as it grows, is manufacturing products. It uses the food material which it gets from the soil and the air to make starch, sugar, oil, and other products. The plant works with only a few different elements, but by putting them together in different proportions it makes several products. Just as our mothers with flour, milk, water, sugar, and yeast or baking powder make many kinds of bread, cake, cookies, doughnuts, and rolls, so nature with oxygen, hydrogen, and carbon makes starch, sugar, and oil. Adding to these elements nitrogen, sulphur, and phosphorus, nature-that is, the plant-makes another class of foods called proteids.

51. Oxygen, Hydrogen, and Carbon.--Three elements which are necessary to every plant produret are oxygen, hydrogen, and carbon.

Oxygen.-Oxygen is a gas that forms a part of air and water. It forms about one fifth of the weight of the air. Forty-seven per cent of the whole crust of the earth is marle up of oxygen. Whenever anything burns you may know that oxygen is present, for nothing can burn without oxygen. Plants, you know, can be 63 


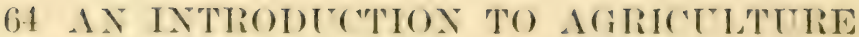

burned. This is because the plant is full of earbon which unites with the oxyenen in the air.

Irydroyen. - Iydrogen is a gass ohdained from wator. It is the lightest gas linown and it bums with a nearly colorless, hot flame.

C'arbon.-Carbon exists eommonly as chareoal. The black substanee on the end of a burned mateh is earlonen. Wood and coal contain earbon, and when they are burned the earbon escalpes to the air in the form of gas. The earbon combines with oxyen and forms this eompound gas called carbon dioxide, or earbonic-acid gas. The breath from our lungs eontains earbon dioxide, as you have learned in your study of physiology. Man and beast do not use the earbon in the air, but plants are constantly taking it in. Carbon is very necessary for their growth.

52. The Products of Plant Growth. - Some of the products which plants produce as they grow are starch, sugar, oil, protein, gums, and woody tissue.

Starch.-- You are probably familiar with starch as a substance used in starching clothes. It is also a valuable food for man. Potatoes are valuable chicfly for the starch they contain. Starch is found in fruits, seeds, roots, tubers, and leares. In making starch the plant combines oxygen, hydrogen, and carbon.

A few drops of tincture of iodine may be obtained from a drug store or from a physician. A drop put into a little boiled starch will tum it blue; this is at test for stareh. By boiling for a few moments small pieces of potato, flour, meal, crushed seeds, pieces of beets, earrots, cte., and testing, the presence of starch may be shown. Pour boiling water over the speeimen in a 
cup) wait until it is cold before applying the iodine test. Any part of a plant, as leaves, bark, or twigs, may be tested for starch in the same way.
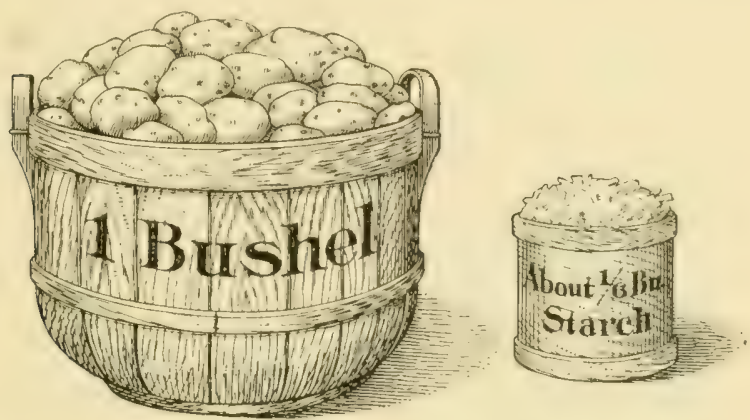

Comparative Yield of Starch from One Bushel of Potatoes.

Sugar, Oil.-Sugar and oil are made from these same three elements. Sugar is found in most fruits, and especially in sugar eane, sugar beets, and sugar maples. Oil is found in small quantities in all grains, and in large quantities in nuts and many kinds of fruits and sects. Olives, for example, contain a good deal of oil.

Protein.-Protein is the name given to a group of food substances containing nitrogen. The most important substance in this group is proteid, which is found in grains and fruits. The sticky part of wheat is proteid. It is abundant in beans, peas, and other leguminous plants. It is valuable as food because it is used by the body in building up muscle. In making protein, the plant uses (as we have noted above) nitrogen and a little sulphur and phosphorus in addition to the three usual elements-oxygen, hydrogen, and carbon. 
Place a teaspoonful of flour on a piexe of (e)arse muslin or linen (an old handlerehief is suitable). Bring the sides and corners up toenether to make a sort of bater. 1)ip it several times into a basin of water and squeeze it. The part of the flour that comes through is starch; and the sticky mass inside the cloth is gluten, a proteid.

Wool Tissue. - What we call womly tisure forms the great bulk of the plant. It is the trunk and limbs of trees. As wood and lumber it is an important product of plant growth. The woody tisiue, like stareh, sugar, and oil, is made with oxyen, hydrogen, and carbon.

53. How the Plant Digests its Food Elements.The plant manufactures its products by the action of the living cells which its leaves contain. In these cells is a green substance called chlorophyll. This sulstance and the sunlight on the leaves acting together change the food which the plant has absorbed. Carbon dioxide, you remember, comes in through the leaves (sece. 4 ). The water absorbed by the roots contains oxyene hydrogen, nitrogen, and some other foods. The water and the earbon dioxide meet in the leaves and other green parts of the plant. There, in a wonderful way, they are combined so as to make starch and the other plant products.

54. Changing Starch to Sugar.- Starch, as we have just learned, is made in the leaves. But as a product of the potato plant, for example, it appears in growths on the root, called tubers. IIow is it movert from one place to the other? Stareh and the other plant produets camnot be moved bodily from one place to another. In a plant there can be no transfer unless the 
material moved is dissolved, or in solution, as we say. Now, starch will not dissolve in water, and therefore if the starch is to be moved it must be changed to something that is soluble. Much of the starch made in plants is changed to sugar, which is soluble. The sugar is then dissolved in water and carried down into the roots and tubers of plants. The sugar is used by plants in their growth and development.

\section{Changing Sugar} to Starch. - This sugar which has been carried in solution is not stored up as sugar, but is changed

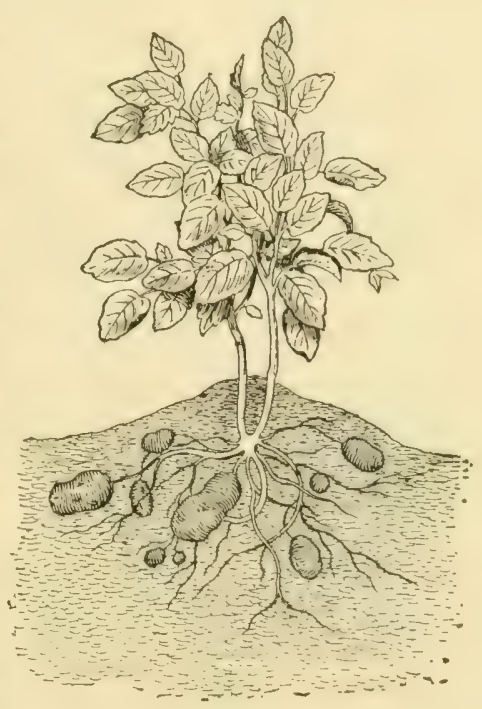

Potato Plant, Showing Potatoes or Tubers. to starch again. The greater part of all vegetable foods consists of such storedup starch.

This stored-up starch may again change to sugar if the plant needs it. The difference between a ripe and a green apple is chiefly a difference in the starch and sugar which they contain. The green apple makes trouble for the boy because the starch is not digestible. If, however, the green apples are cooked and made into pies or sauce, the starch is made digestible and causes no trouble. A change from starch to sugar is indicated by the sweet 


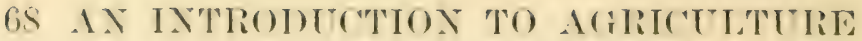

tastr of sprouting potatoes and roots. In ripening fruit also the stored-11p) starch is chamering to surar.

56. The Composition of Certain Vegetable Products.-The following talsle will give an islea of the amount of starch and sugar, oils, and protein in varioms vergetable products. Ftareh and sugar are combloned under the head of carbohydrates:

Thble showing Arerage Percentage of Digestuble Carbohydrates, Fats or Oils, and Protein. ${ }^{1}$

\begin{tabular}{|c|c|c|c|}
\hline & Protein & Carbohydrates & $\begin{array}{c}\text { Fat or } \\
\text { Oil }\end{array}$ \\
\hline Corn. & 7.14 & 66.12 & 4.97 \\
\hline Wheat. & 10.23 & 69.21 & 1.68 \\
\hline 'Timothy hay........... & 2.89 & 43.72 & 1.43 \\
\hline Potatoes....... & 1.36 & 16.43 & \\
\hline Carrots.... & .81 & 7.83 & .22 \\
\hline Alfalfa hay. & 10.58 & 37.33 & 1.38 \\
\hline Clover hay (red) & 7.38 & $3 S .15$ & 1.81 \\
\hline Apples......... & .7 & 18 . & \\
\hline
\end{tabular}

57. The Production of Heat.-It is interesting to know that a plant, like an animal, produes heat when it is growing. Although the amount is small, experiments have proved that the temperature of sprouting secels may be $18^{\circ}$ to $: 36^{\circ}$ Fahrenheit higher than that of the surrounding air. In the act of flowering, plants may be as much as $1 t^{\circ}$ Fahrenheit warmer than the surrounding air.

Into a wide-mouthed bottle place a number of seeds ready to germinate. After twelve hours cork the bottle tightly, and through the erork run at thermometer after taking the temperature of the room. Several hours later read the thermometer.

${ }^{1}$ Farmers' Bulletin .10. 22, revisen edition, except the figures for apples. By courtesy of the Onfiee of Experiment stations. 


\section{PLANT FOOI) ANI) IIOIV IT IN TSEL 69}

58. The Production of Seeds.-A studly of plant lifo seems to show that so far as the plant is eoneerned, the object of its existence is to produce seed. This, then, is another important use the plant makes of its food and appears to be the most exhausting effort the plant makes. When the seed is produced, the plant stops its growth for the season, and in many cases dies. Some plants produce seed and die in one year. These we call annuals. Others store up nourishment for one year, use it all the second year in producing seeds, and then die. Such plants are biennials. Clovers and some other plants, if eut before they bear flowers, make an extra rapid growth to complete their work of produeing seed. The farmer can profit

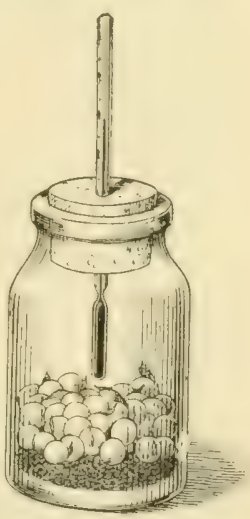

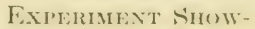
ING IIKAT (iNWN ()FF 135 (inkMINitive: SFHAs. by this and get several erops of elover or alfalfa in one season.

Seeds form a large part of the food of man and animals. It is, therefore, greatly to our advantage that plants serm to give all their energies to the production of seeds.

\section{SUMMARY}

The plant combines certain elements to manufacture products. - Important elements in the growth of plants are oxygen, hydrogen, and carbon.- ()xygen and hydrogen are gases whirh in combination form water.- ('arbon is an element that exists commonly as a black mass in charcoal. 
The plant, like the animal, uses its food to builu up tissue, to make chemical changes, and to produce heat. - The plant makes stareh, sugar, oils, protein, and woody tissue. - Citarch, sugar, oil, and protein are valuable foods for man. - P'roteid is an important food substanee foumd in arains, fruits, and lecumes.

The food elements are mamufaretured into products in the leaves and other green parts of the plant.-Insoluble stareh may be changed to soluble sugar and carried to some part of the plant where it is agrain (hanged to starch and stored up) for future use.

Vigorous growing plants produes some heat, but not so much as animals.

The produetion of seeds is the most important thing the plant does.

\section{QUESTIONS AND PROBLEMS}

I. What is the difference between starch and protein?

2. Name ten foods that are eaten chiefly for the starch they contain.

3. Why is it better to store up food as starch than as sugar?

4. Why does the plant sometimes change its starch to sugar?

5. Why are ripe apples safer to eat than green ones?

6. Would you cut elover before it hlossoms? Why?

7. Water is $\frac{1}{9}$ hydrogen and oxygen by weight. How much oxygen is there in 45 pounds of water?

8. How many pounds of arbohychates, fats or oils, and protein are there in 20 bushels of corn? In 25 bushels of oats?"

9. How many pounds of atpples would you have to atit to get as much proteid as a pound of potatoes viclds?

ro. Which of the foods listed in the table on parge fis has the greatest amount of food stuff in a pound?

rr. Name the products of the following plants: Sorghum, carrot, flax, hemp, oak trees, hickory.

1 A busled of outs weighs i:2 poumds. A hushel of corn iti pounds. 


\section{CHAPTER VIII}

PLANT ENEIIES: WEEDS, INSECTS, AND PLANT DISEASES

59. What a Weed Is. - A weed is a plant growing where it is not wanted. It is a plant so well adapter! to the place where it grows that it crowds out more desirable plants. A plant that is an annoying weed to some farmers may dsewhere be cultivated in flower gardens. For example, the sweet clover is a weed in the Central States, but it has been cultivated in New England gardens for its attractive blossom.

6o. Why Weeds are Enemies.-Weeds are cuemies because they prevent the growth of plants that are wanted. If a man wants to raise lettuce and finds half of his crop purslane, although he might eat the pursine for greens, yet he will be disappointed. Treeds generally grow fast and vigorously. They take from the soil moisture needed by the erops, which dry up without it. Weeds take also the plant food and so rol the erop. The amount of available plant food in the soil at any one time is limited, and a few days of rank weed growth may use up a season's supply and retard plant growth until more is made available. Weeds frecpuently have large leaves, and they cover the ground and liecp from the 


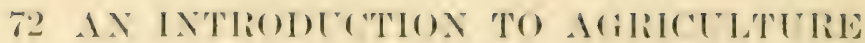

growing (oop) the sunlight which it necels. They also furnish loogring and food for inserets that may latre at tacki the crop. Fomotimes they joison animals in a pasture. It all times they are umsighty and a discrrace to the owner. "I went by the fiest of the slothful, and hy the vinevard of the man void of understanding; and lo! it was all grown over with thorms, and nottles had corered the fitce thereof." It is important to note that ecrtain werels follow certain crops and certain methods of farming.

6r. Classes of Weeds.-Meeds, like other plants, are dividerl into (rasses-ammuals, biennials, and perennials, acrording to their habit of producing seeds and length of life. The chichweed is an example of the first class. It comes un from the seed in the spring, blosioms in mirlsummer, produres seeds. and dies the same year. Biemials maty be represented by the bull thistle. This plant romes up from the seed, and the first year does not blossom but stores up) nomrishment. The second year it uses the momishment to produce seed and then dics. Berots, carrots, turnips, and surhe plants as prodnee a fleshy root the first roar are liomials. An example of the thirel chass is the Camada thistle. It romes 11) from the serel, produces sered after one or more years, and romtinues to live porhates for many years. P'orennial herls die down to the erromel in the fall and errow again from the mots in the spring: shrubs and trees live on year after year.

62. Annuals, and How to Kill Them.-Ammual weeds follow tilled orops. Amone the ammal werels may he mentioned the pigweed, shepherel's purse, purslane, rag- 
weed, prickly lettuce, and smartweed. In fact, most of the common garden weeds are annuals. These are the easiest to kill. If they are prevented from going to seed, and if the young plants are hoed up and covered, that is the end of them. The seeds of some weeds are deeply buried, and as the land is cultivated these are brought near the surface and soon sprout. Constant watchfulness is therefore necessary even after the first growth of weeds has been cleared away. It is often well to let the ground lie a week or two after plowing before it is seeded, so that the weeds may have an opportunity to sprout. They will then be killed by the

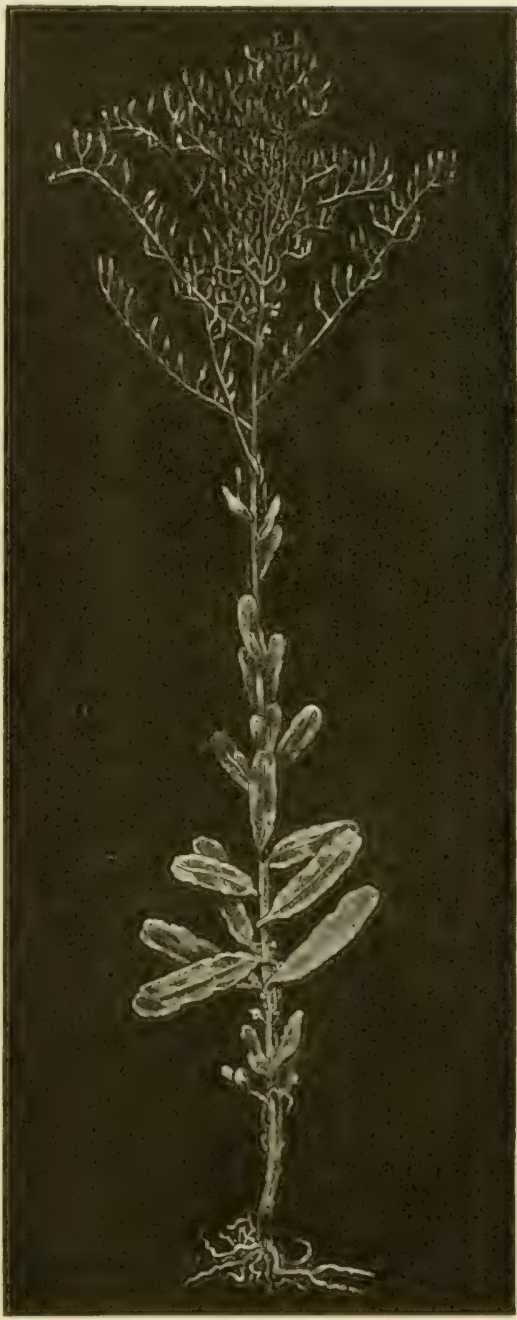

The Common Prickit I.fetuce (Annual). 


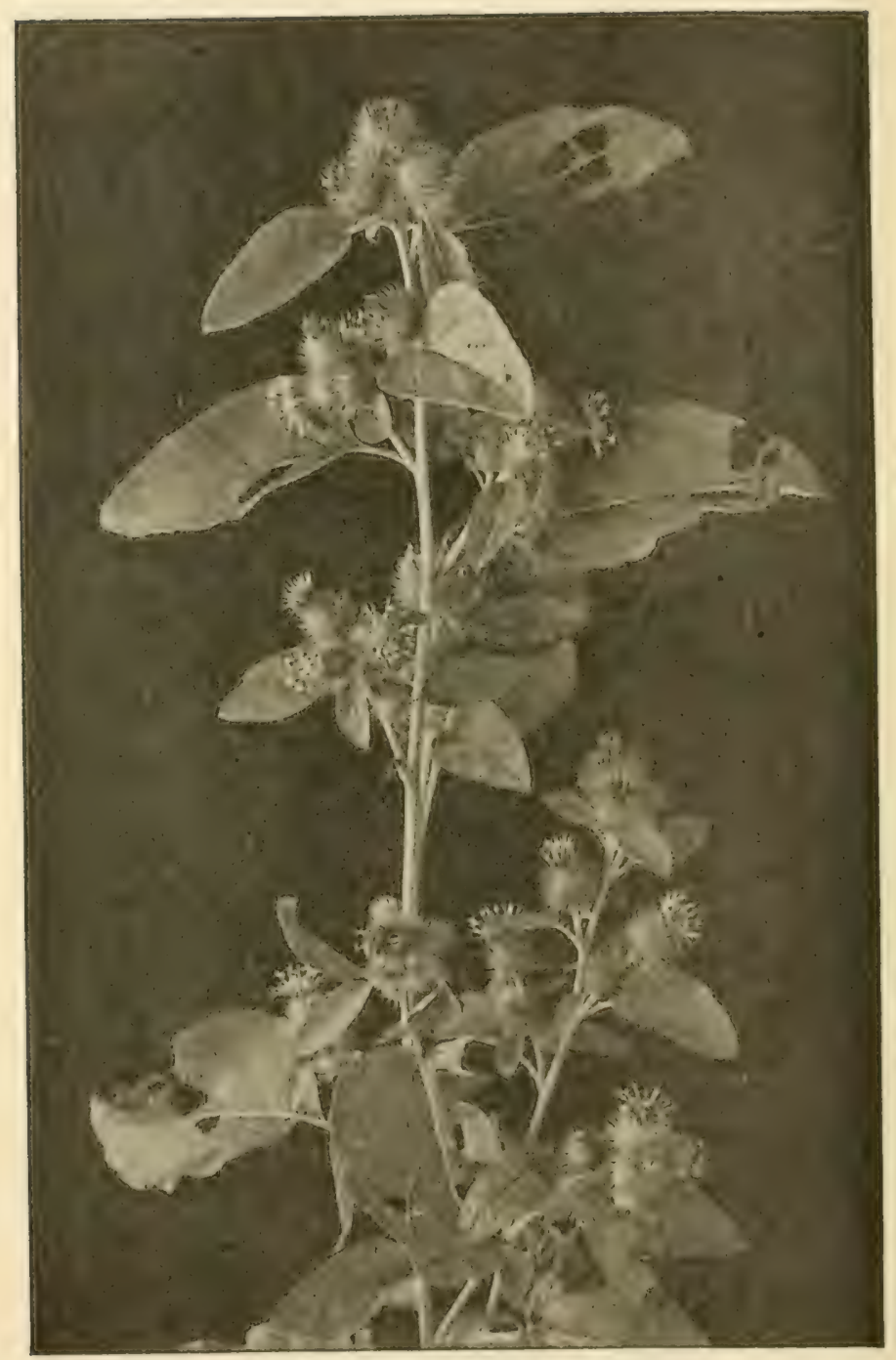

Small-leaved Burdock (Biennial). 
cultivation incident to planting. This gives the crop a chance to start before a new lot of weeds springs up. Many annuals, and other weeds as well, may be killed by burning over a piece of ground before plowing. It is necessary only to prevent seeding to exterminate annuals.

63. Biennials, and How to Kill Them.-Common bicmnials are burdock, wild parsnip, teasel, poison hemlock, and bull thistle. It is more difficult to get rid of biennials, for even though they are mowed off, the roots are left in the ground and they may send up a stem to produce seeds the second year. On small patches, as lawns, this class of weeds may be killed by cutting off the plant just below the ground with a longhandled chisel called a spud. Any cultivation that prevents such weeds from going to seed will help to free the land from them.

64. Perennials, and How to Kill Them.-The great majority of weeds are perennials. Among these may be mentioned Canada thistle, plantain, dandelion, oxeye daisy, mallow, yellow dock, and toad flax or snapdragon. These are the most difficult of all weeds to destroy, because both the tops and the roots must be killed. As with the other two classes, seed production should be prevented by persistent mowing. The root or underground stem should be plowed up or dug up and exposed to the sun of summer and the frost of winter or raked off and burned. The roots may sometimes be starved by preventing any green part to live above ground. For example, dandelions in a lawn may be killed by cutting off the plant an inch or more below the 


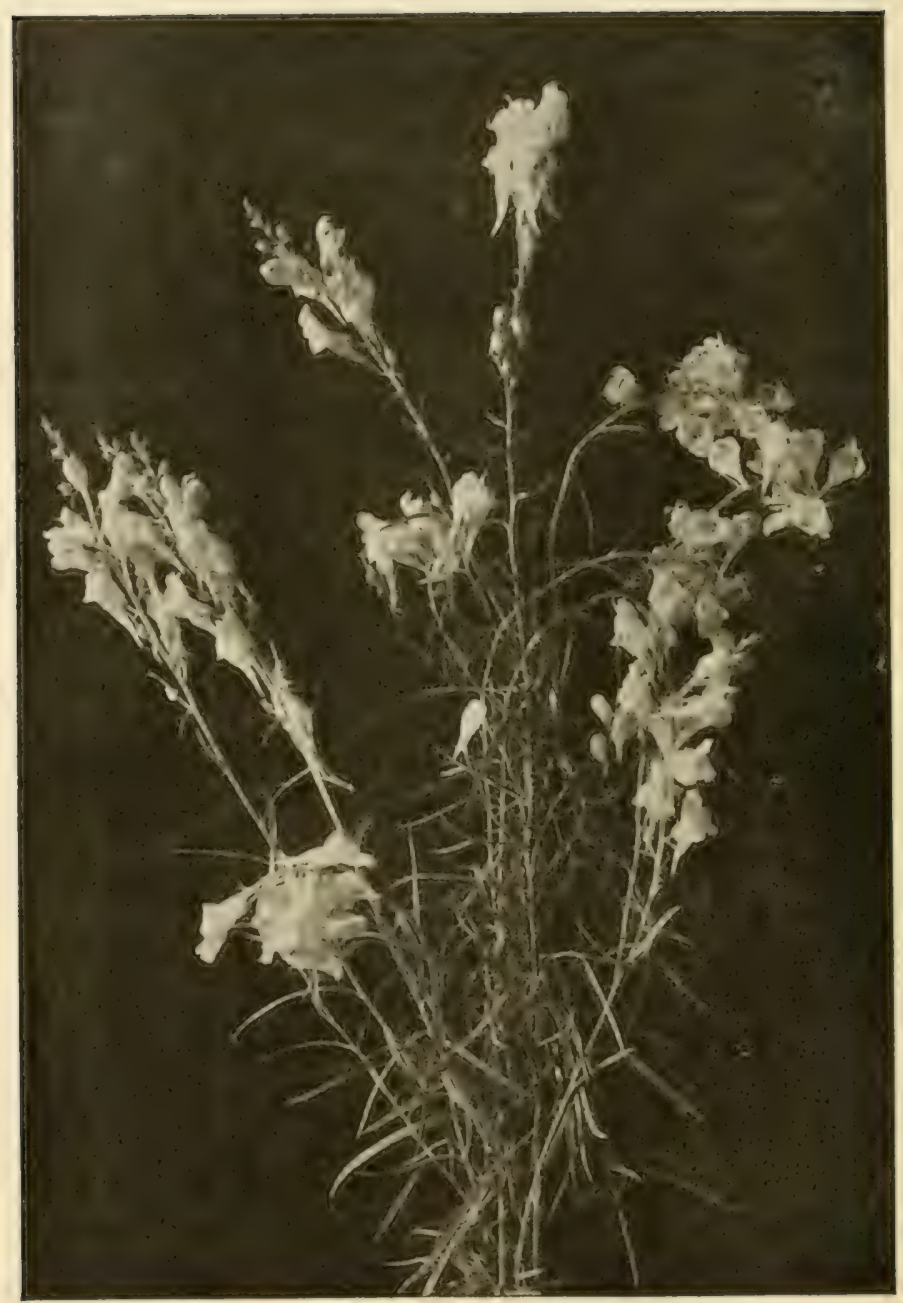

Toan Fiax (I'rennial). 
surface of the ground and pulling out the top. This can be done very rapidly with a spud.

On small areas weeds may be smothered by eovering with straw so that they will get no air or light; on large fields a sod-forming grass may be grown for the same purpose. Salt, or strong acid, is sometimes used on small areas to kill the roots of weeds.

In general, it may be said, the three methods of killing peremials are prevention of seeding, thorough and continued cultivation, and smothering by crops. Recent experiments show that wild mustard and some other weeds may be killed or checked by spraying with certain chemicals, as a ten-per-cent solution of iron sulphate. This does not injure cereals, corn, grass, or clover, but retards the growth of weeds to such an extent that the erop is increased twenty per cent. ${ }^{1}$ There can he no effective weed control unless fence corners, roadsides, and waste places are kept clean.

Let each pupil bring into class every noxious weed he can name.

65. Description of an Insect. - An insert is a small animal that has six legs and its skeleton on the outside. The body is divided into ringlike parts attached to each other. These are called segments and are in three groups-the head, the thorax, and the abdomen. The head has attached to it the jaws, ferders, and eyes. The thorax has three rings, to which are attached the six legs and the two or four wings, if the inseret has any.

'Science, November 22, 1907, p. 694. 


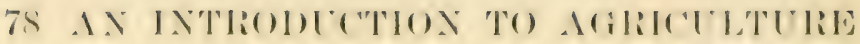

The aldomen is segmentexl and has a row of pores or breathing holes along each side.

66. Life History of Insects. - Inserets hatch from nerges as do many other animals. but instratel of growing regularly, they pass through a change, or melumorphesis, as it is called, the young being somenthat different from the atult. For example, the young of the butterfly and moth is a caterpillar having a womlike borly. and many legs. This catcrpillar, which is called a larvat,

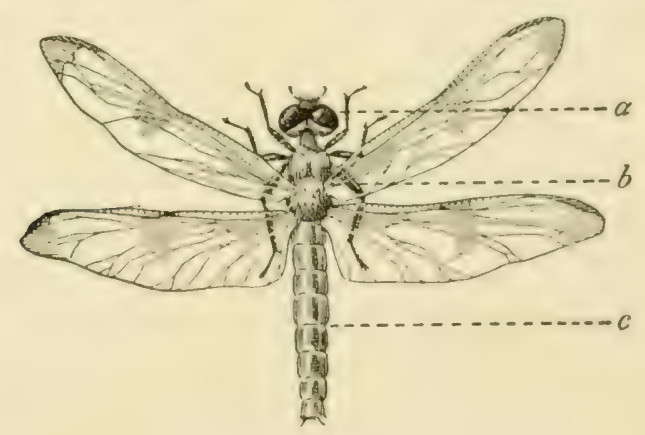

Trpical INsect, $a$, head with cyes and mouth parts; $b$, thorax, with legs and wings; $c$, abdomen, showing segments.

grows rapidly and then passes into the pupa stage. In this stage it is inclosed in a rather hard shell often covered with a silk case called a cocoon. It is quiet, and ats nothing. It may oceropy this stage for days, wereks, or eren over winter. After a time it comess out as an arbult inseret. It is in the larral stage that many inserets do their harm by cating vecetation.

fome inserets, as the squash bug, the grasshopper, and the ericket, do not patse through a complete change, 
but have, when hateherd, the same form as the adult, exeept that their winges are wanting. Such inserts molt, or sherl their skin, several times; and after cach molt their wings are larger than before.

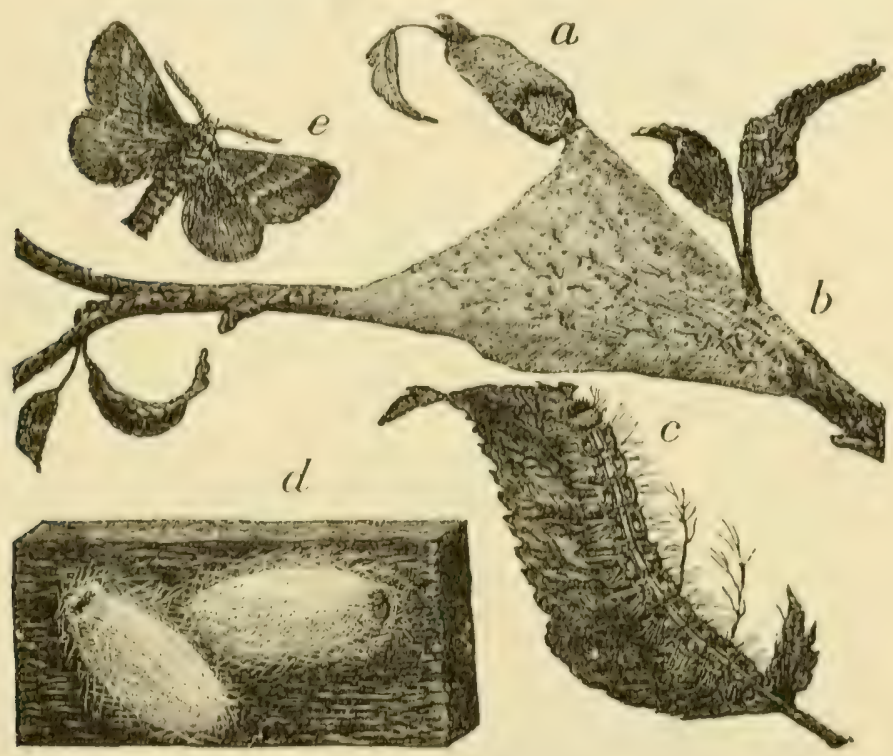

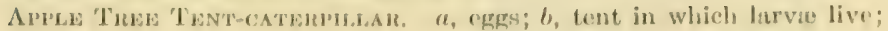
$c$, larva feeding; $d$, cocoons; $c$, adlute male moth.

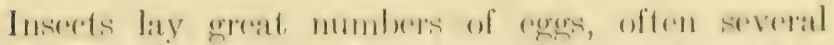

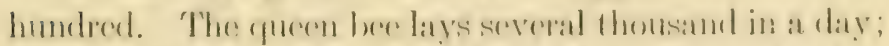
and it is said that white ants laty cighty thomsand a daty for two years.

67. Classification of Insects. In atrricultural dis-

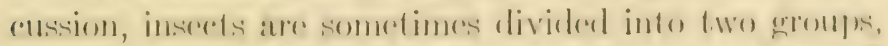
cullimy and sturling inserets. ('ulling inserels hite ofl 


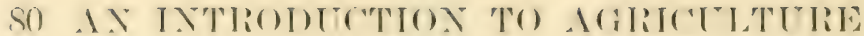

farts of the leaf or plant and devour thems. Sinch inscels are somotimes so mumeroms that they strip a hush or trees of its leaters in a fow homrs. Surbinge inserets insert their lome. semeler momth parts inte the plant and stork the juices from it. Sume inserets belome to ome gremp) in one stage of their existence, and to the other group in another stage.

68. Some Common Cutting Insects.- Tximmles of the cotting inserets ale the larve of the rodling moth, the camker worm, the cablatere worm, and the potate heetle.

The corlling moth is ome of the most injurious of inserets. The anlult is a small erray moth alout ome half

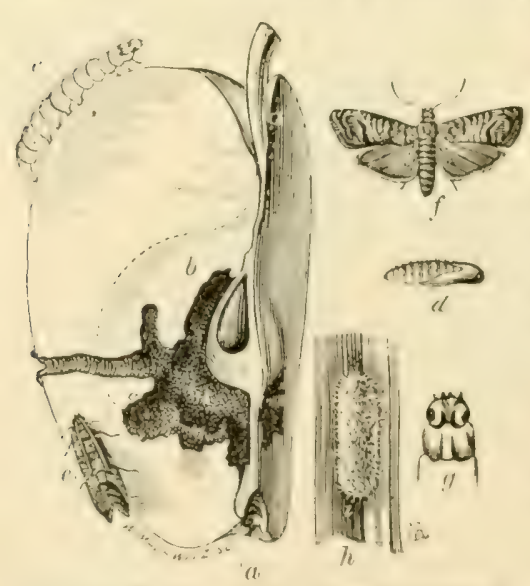

(index: Nerir. a, the entranee liole: b, the burrow; $c$, the larva; $d$, the pupa; 1. muth at ret: /. moth with wings

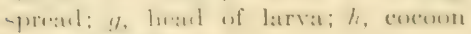
(c)ut:tinime pun:s. inch long. It lays its egras on the leaves or on the apples just as the petals fall, or later, if it is the second generation. 'The larvo hatch and feed their way into the apple, which may soon fall if it harbors the first generation. Afterwards the larve work their way out of the apple and rratwl into a crerier of the latrk or other similar plarer. from which they emorere as alult insorets. If it is the last hrouel of the seat-

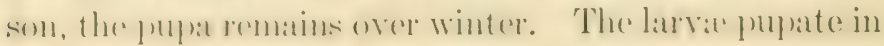


some crack or hole, or under some seale of the bark. If the tree is too smooth they drop to the ground and go into it through some crack, or remain under rubbish or clods. The larva is the white worm so familiar in apples.

The canker worm is the larva of a small ashcolored moth, the female of which is wingless. The larva is sometimes called the measuring worm because of its method of traveling by looping its body. The eggs are laid in patches on the bark of a tree. The larvæ will strip the foliage of the tree with great rapidity. After the worms have matured they swing themselves down by a silken thread, burrow in the ground, and there go into the pupa state. The last brood stays in the ground over winter.

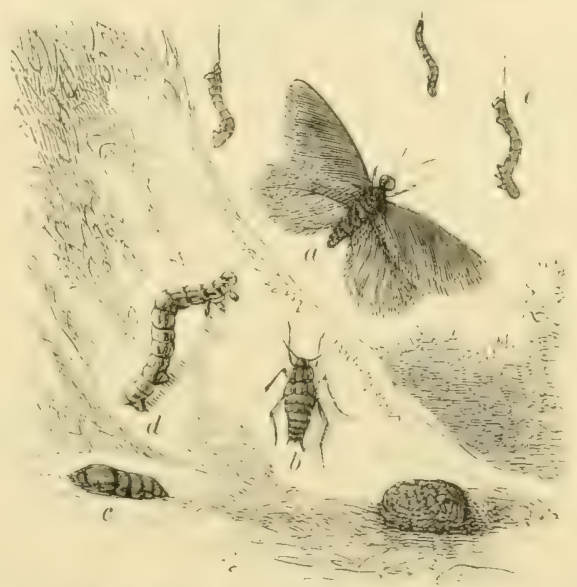

CANKER Worm. "arlult male; b, arlult fomale moth; $c$, elunter of egrge; d, larva: e, larva swinging down from a tree to burrow into the ground.

The cabbage worm is the larva of the well-known white cabbage butterfly. It is greenish in color, tapering at each end, and covered with fine white down or hair. The egges are laid on the leaves of the plant. In ten day's they hatch, and the larvie feed about three weeks. The pupa stage is only about two weeks. 


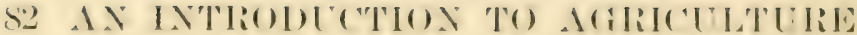

There are generally two broods in a season, one in May and one in July.
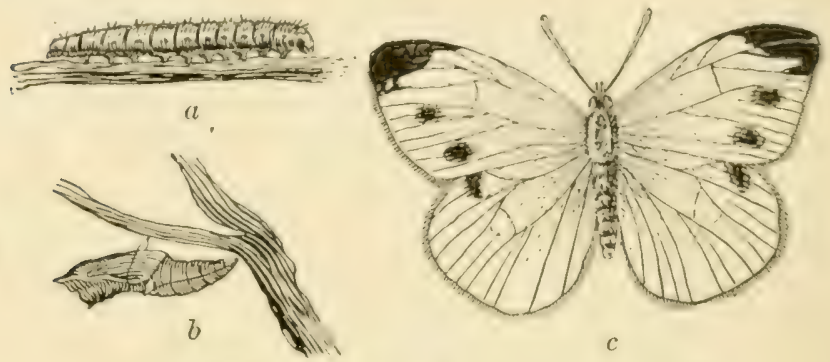

CAmBage Worm. $a$, larva; $b$, chrysalis; $c$, butterfly.

The potato beetle at one time eaused an immense amount of damage. The adult is about one half inch

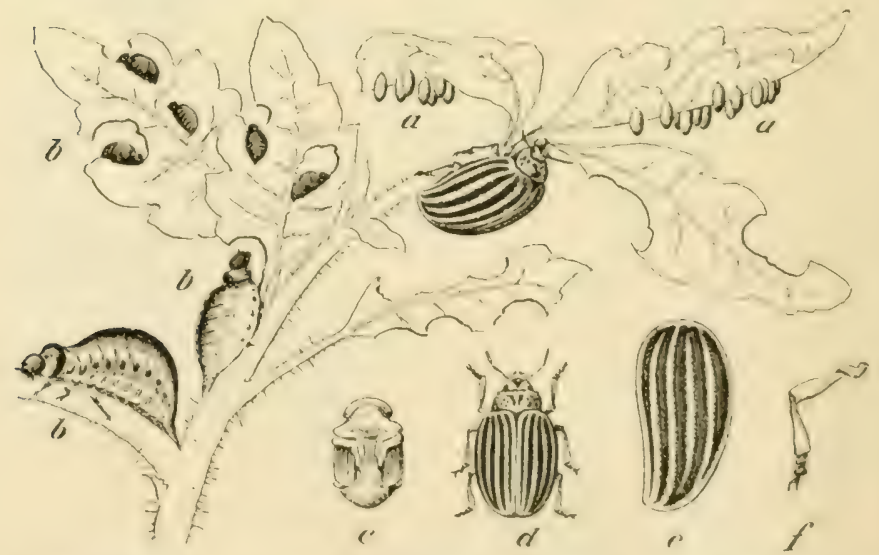

Potato Beetre. $a$, eggs on underside of leaf; $b$, larva that eats the leaves; $c$, pupa; $d$, perfect insect; $c$, wing cover; $l$, leg.

long with ten stripes along the hack. In the Central States there are three broods, the last one remaining in 
the ground over winter. The other two feed about twenty days each, and remain quiet in the ground about ten or twelve days. The larvie will double in size in a few hours.

69. Some Common Sucking Insects.-Examples of sucking insects are plant lice, chinch bugs, the Hessian fly, and the grape phylloxera. Plant lice is the name given to a group of small insects that have long beaks with which they pierce the plant and suck the juices. Some are protected by a thin covering, from which they get the name of scale insects. A noted example of these is the San José scale insect, one of the most destructive to orchards. This insect is so dangerous that in some states it is illegal to sell trees infested with it.

The chinch bug is less than a quarter of an inch long, but it is said to cause more damage than any other known species of insect. It is brown in color, with white fore wings, each having a dark spot near the micldle. These insects are the greatest enemies of the wheat crop. They sometimes attack corn also, "fairly blackening the stalks with their bodies." Almost as harmful to the wheat crop as the chinch bug is the Hessian fly. The eggs are laid in the leaves of the wheat. The larve attack both

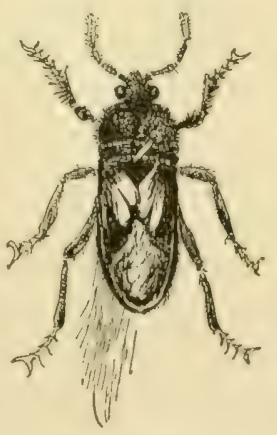

Chincil Bug. the root and the stalk.

The grape phylloxera is a very destructive insect that stings the roots and sucks the juice of grape vines. Another harmful insect is the plum cureulio, which lays 


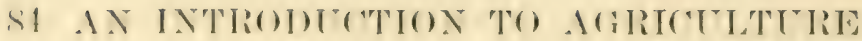

its enges in the ereen fruit. From these exeres the young hateh and feed upon the plums, which soon drop off. There are many other insects injurious to vecgetation, for an aceount of which the student is referred to the books and pamphlets listed at the end of the book.

Let each pupil bring into rlass all the albove-named insects he can eatch.

7o. Insect Control.-Biting insects are exterminated by spraying the foliage with poisonous mixtures so that the insects take the poison in their food. Sucking insects are destroyed by actually being hit by the spray. Good standard insecticides for hiting insects are Paris green and London purple. For sucking insects, the most eommon remedy is a kerosene emulsion. This deses the breathing pores so that the insect is smothered. Formulas for the various insecticides will be found in the Aprendix. These liquids are applied with a spray pump mate for the purpose. For the codling moth spraying is sometimes done as many as five times with a combination of Bordeanx mixture and Paris ereen. The first spraying is clone as soon as the petals have fallen, the second three or four weeks later, and the third about nine or ten weeks after the petals have fallen; the fourth and fifth at intervals of two or three weeks. It is often necesary to hand piek or dig ont insects.

Inseret enemies may be greatly diminished in number by carefully collereting and hurning all rubbish, such as fallen limbs of trees, twigs, and stuhble. Firgs and the wintering insects may be hidelen there, and the burning will destroy them. Neatness then brings its own reward. 
Prepare some kerosene emulsion and Bordeaux mixture aceording to the formulie in the Appendix and try them where needed.

7I. Nature of Plant Diseases.-The third great enemy of the farmer's crop is disease. Plant diseases are caused by bacteria, molds and fungi, organisms that belong to a group of low regetable forms which, not having chlorophyll in their cells, are obliged to get their food from some higher plant.

These low forms grow mostly from spores, which take the place of the seeds of higher plants; sometimes they propagate by divicling into two or more parts. These spores are very small and innumerable, and are light enough to be carried by the wind. Familiar evidences of these lower plants are corn smut and wheat rust. When broken, the corn smut, as is well known, sends out a great cloud of brown dust; each particle of this dust is a spore, which may produce other corn smut. Because of the vast number of spores, these organisms are multiplied or propagated with great rapidity.

The leaves of gooseberries in the spring may often be seen to have light yellow spots on them. These spots are "rust" and are the result of these spores. The white coating on the surface of lilac and pea leaves is a familiar example of mildew.

\section{Some Common Diseases and Their Treatment. -} Some of the most familiar plant diseases are the fire blight, oat smut, potato scal), potato blight, peach curl, black knot, and fruit mold.

The fire blight gives to the end of apple and pear tree twigs the well-known blackened appearance. It is 
(atsed hy hacteria growing in the inner layer of the bark. The twies should be at off and burned.

The oat smmet is a fungus which does murh damage

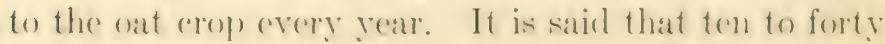

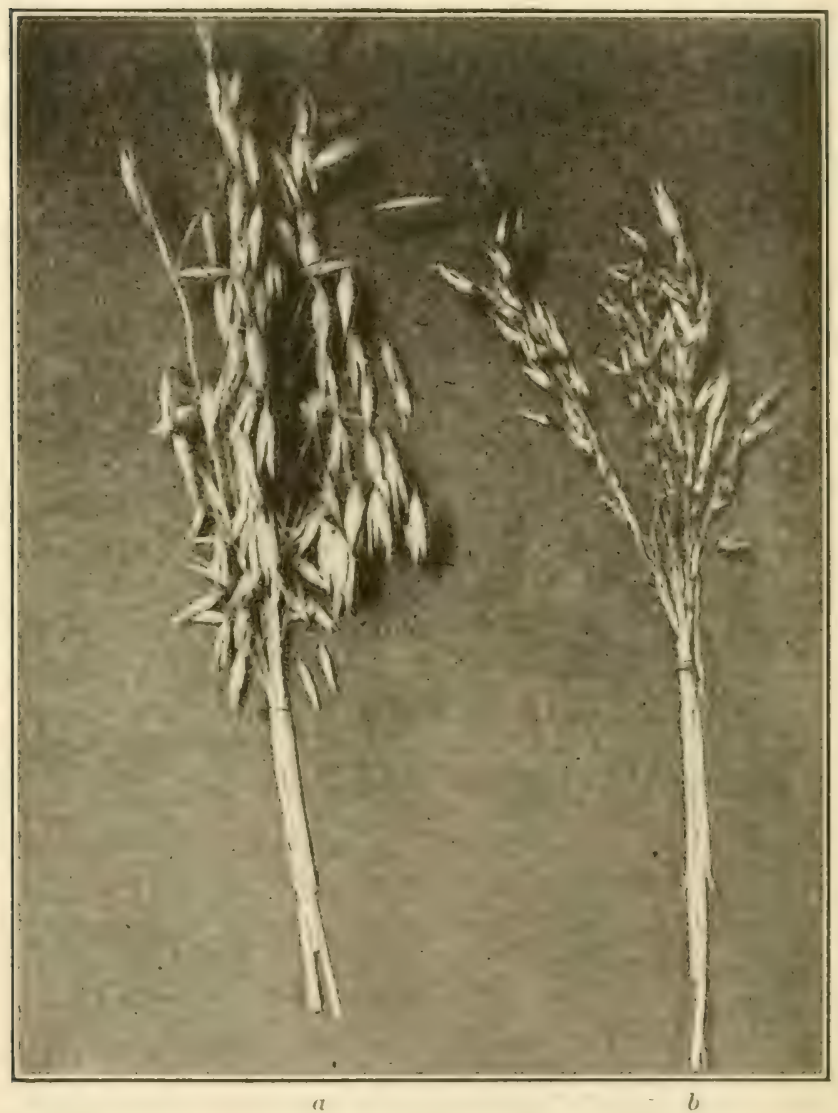

a-Five Heats of Crean Oats. b-Five Heans of Surutty Oats. Note the black smut in the grains and the small size. 
per cent of the (rop) is annually ruined by this disease. In the spring when the seed oats are planted minute spores of the oat smut are sown with them. The smut spores begin to grow about the same time that the oat seed does. They form very small threads-smaller than a cobweb-down in the ground. You have noticed such threads when mold grows on bread. The little threads enter the young oat plants, the sap of which they use for their food and grow rapidly. The plint is weakened by furnishing food for all these threads that run through its roots, stem and leaves. When it is ready to blossom and form oat seeds, the fungus is ready to produce black spores. The ends of the threads grow out on the head of grain and give rise to immense numbers of minute, black spores. The oat plant has not had a fair chance and it will produce few oat seeds as a result. If the farmer cuts the oat plants and carries them to his barn, there will he millions of these spores among the grain. Some of them will be mixed with the good oats and when sowed the next spring will produce the same or worse results. If, however, the oats that are to be planted are soaked for twenty minutes in a weak solution of formaldehyde, made by pouring one pint of formaldehyde into a barrel of water, the smut spores will be killed and the oats will not be injured. They will be just as good for planting but must not be fed to stock after being soaked in the formaldehyde.

The milclew that attareks grape vines consists of fine threads similar to those just described. It can be largely prevented by spraying the vines with the Bordeaux mixture. 
Potato scab), familiar to all fammor, is a rased hy at fumgus that grows from sporese on the sorel postato or in the groumel. The remenly is to sonk the sered pestate in the formaldehyelesolution. If the grommel has produced potatoes for some time and the spores are in the eroment.

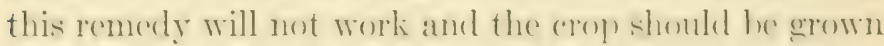
elsewhere for a geriond of yours. Potato hlight afferets the leaves and travels from the leaves and steme down into the tubers, eausing them to rot. It may be controlled by spraying with Bordeaux mixture.

Prepare the formathlehyde mixture and trat some seathy potatoes and smutty oats. Plant some small patches with the treated sereds and others with the untreated secels, and see whether there is a difference in the product.

Mixtures for destroying fungi are called funceriedes. Directions for preparing and using fungicides may be found in the Appendix.

\section{SUMMARY}

A weel is any plant that grows where it is not wanted Weets are enemies beratuse they absorb moisture and take the plant food needed by the crops.-Weeds, like all other plants, are divided into annuals, biemnials, and perennials. - Imnuals and biemials maty be destroyed by preventing their geneng to seed.- l'erennials must be duer up) and destroyed from the routs.

Many kinds of inserets do serious harm to plints.-It is in the eaterpillar or larval stage that inserets generally destroy vegetation.-Inserets are rlatsond as eutting and sucling inserets. -The rutting insect eats off leares; the surking inseret takes the juice of plants.-Insects may be destroyed hy spraying with poisonous mixtures or various other liquitls.

Plants are subject to diseases in the same way that animals are.-l'lant diseases are called mildews, scalss, molds, and smuts. 


\section{PLANT ENEMIES}

- These diseases are eontrolled by eutting off and burning the diseased parts and by spraying with various solutions.

\section{QUESTIONS}

r. Why is it more difficult to exterminate a peremnial weed than an annual?

2. Name some of the worst weeds. Are they annual, biennial, or perennial?

3. Why are Canada thistle and dandelion hard to keep in check?

4. Name a half dozen injurious insects.

5. Which is it better to kill, a moth or a grub? Why"?

6. How does a blight injure a plant?

7. Why should the dead vegetation around a wheat or oat field be burned?

8. Why will not Paris green kill sucking insects?

9. Is it better to let the windfalls from apple trees lie on the ground or should they be fed to some animal? Why".

ro. Which is the better farming, to prevent weeds or to kill weeds?

II. Is it good practice to allow weeds to cover the ground after garden crops are gathered? Why? 


\section{CHAPTER IX}

THE FARMER'A FRIENDS: BIRINA, TOAIN, INSE(TA

73. Birds and Their Food. - While a large part of the farmer's work consists in fighting insects, weeds, and other injurious things, he has some valuable friends who work with and for him. Probably the most valuable are the birds. They aid the farmer by ating insects and seeds of weeds. To some extent they eat injurious animals, such as mice and gopher's.

Toung birds grow rapidly and recuire a great amount of food. Many of them are fed mostly on insects. It has been estimated that a pair of sparrows will earry more than three thousand caterpillars to their nest in a week. A young robin kept in ('aptivity was feed sixty earthworms a day, and an observer clains that a pair of young European jays were fed a half million caterpillars in a single season. I'rofessor F. II. King, in olservations made in Jefferson ('ounty, Wisconsin, and in Ithaca, New York, counted on an average thirty-three birds per mile in Wisconsin and fifty-seren per mile in New York. It is probable, as he says, that this number represents not more than half of those oceupying each sifuare mile. Is it not evident, them, what a great and constant help) the birds are to the farmers? 
74. Useful Birds. - Birds that help the farmer may be divided into three groups: First, those that live chiefly, or prefer to live, upon animal food, such as insects in their various stages. Among these birds may be mentioned the robin, thrushes, bluebird, kinglet, searlet tanager, bobolink, kinghird, pewees, black-billed cuckoo, and woodpeckers. Second, those that eat both animal and vegetable food. Among these may be mentioned the catbird, brown thrush, white-bellied nuthatch; chipping sparrow, marsh robin, and purple grackle. Third, those that prefer a vegetable diet of seeds. Among these may be mentioned the finches, thistle bird, and indigo bird. It is not to be understood that hard and

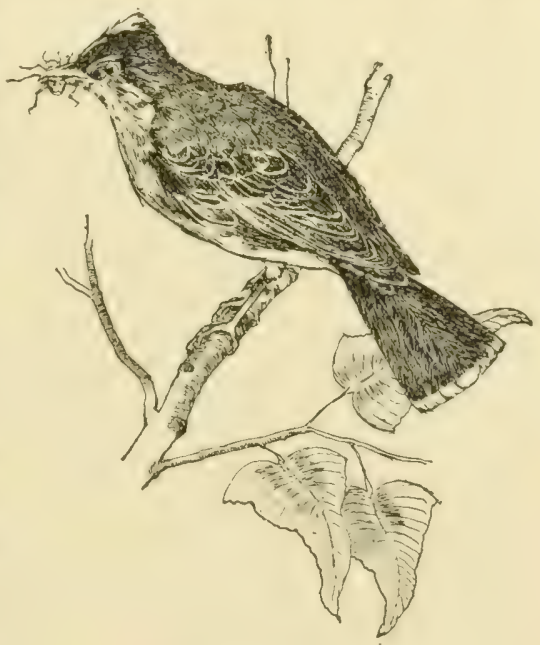

KIINGBIRI). fast lines can be drawn among the birds in regard to their food. Birds have their preferenees, but the season of the year and the abundance or seareity of a giren food determine to a large extent the kind of food caten.

The robin is a diligent secker for caterpillars, cutworms, white grulos, and carthworms in lawns, ficdes, and mearlows. In early morning and late evening, this bird may be seen awaiting its prey. All of a sudken it darts 
its bill inte the ereound and hrings up a worm. The

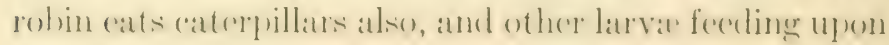
shrubs and vines.

The thrushes spend most of their time in thickets and trees, and some observers have conserpuently

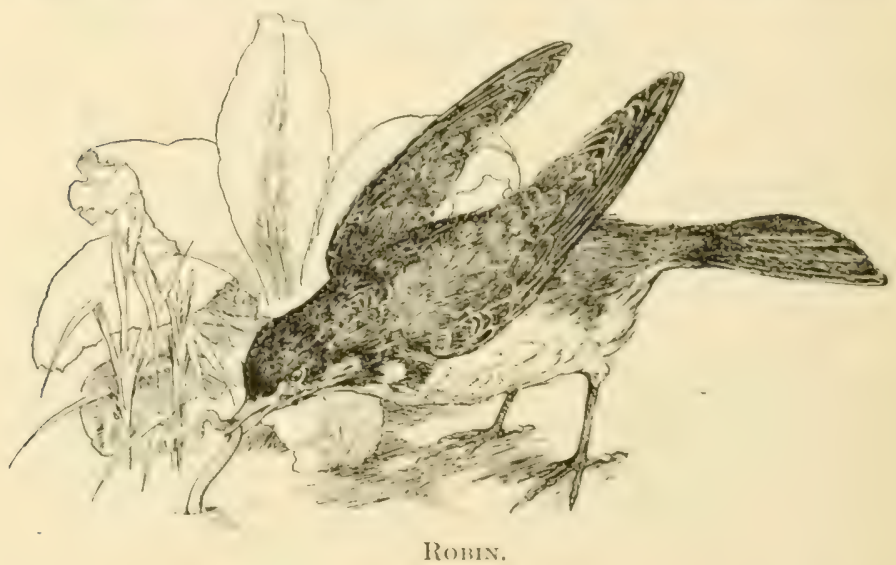

thought that they rat buds. In examination of the stomachs of numbers of thrushes, howerer, hats indicated that serenty to ninety per cent of their food is ground-infesting insects and larvæe.

The bluebird eatches its prey either on the wing or on the ground, thus taking a wide range in its fecding. It comes early in the spring, rears two or three hrookts of young, and for their food destroys an immense number of inserts. The bluebirel serems to like enltivated fiedds and the society of man, and thus its activities are in an especially useful place.

The searlet tanager is a beautiful bircl that inhabits 
the border of woodlands and, to some extent, orehards. From the woodlands it makes exeursions inte the artjacent fiekls to eapture insects. Although it eats cherries, its useful work fully offerets the damage it does.

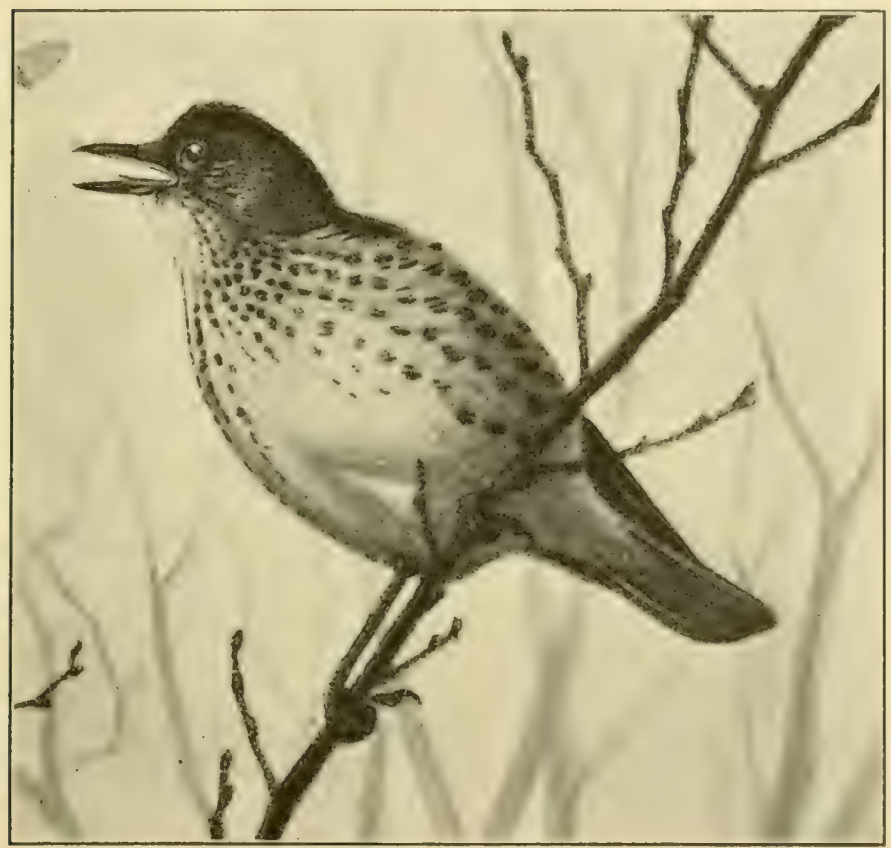

Wood Tinrusir.

The woodpeckers and their habits are weell known. These birds spend their time seeking the latrve hidelen in the creviees and under the bark of trees. The goldenwinged woodpecker grets its food both from the trees and from the gromol, its favorite food being ants. IIost of the woodpeckers undoulbtedly are beneficial, although 


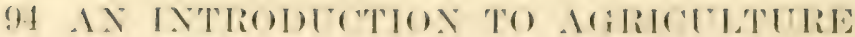

sometimes they may do some ramaer he rating useful insects.

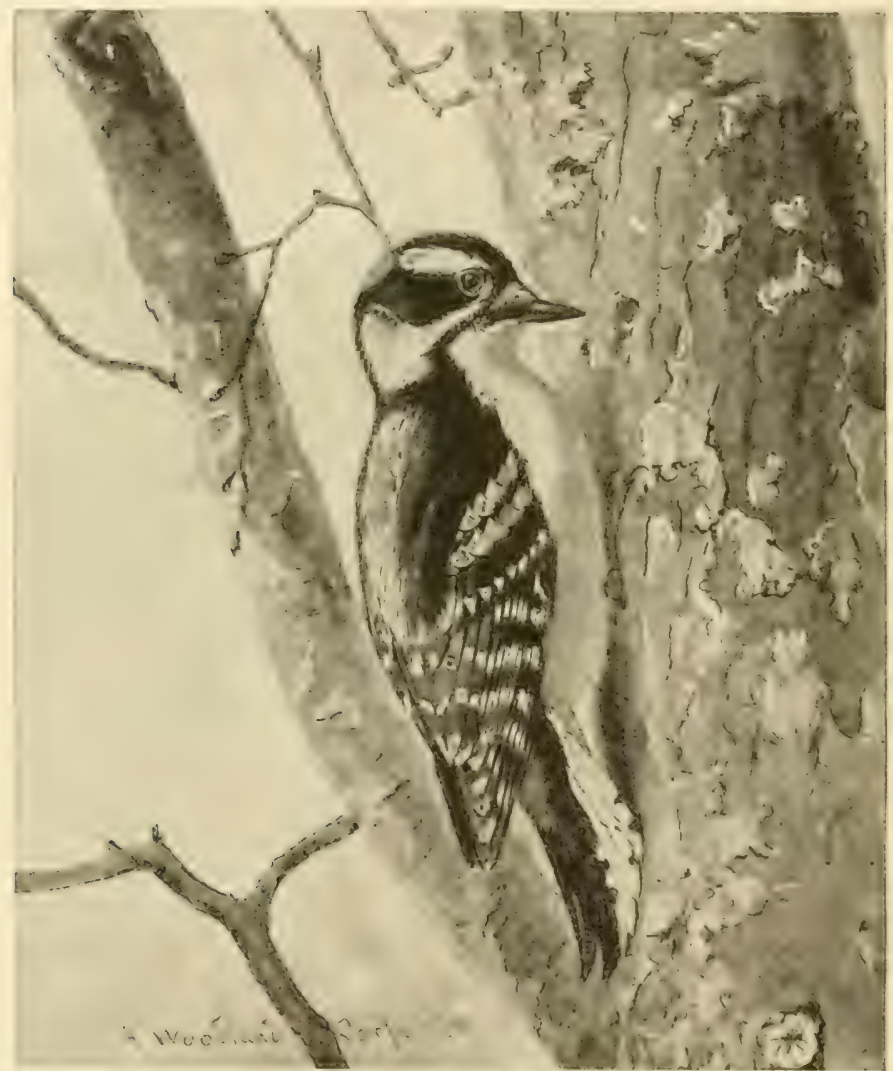

DOWYY WOONECKYR.

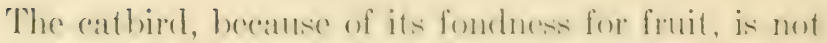
to he ramkel amonge the most mseful higls: hot it is generally acread that it does more goud than harm. Its 
haunts are the underbrush and brambles, which are good hiding places for larvar, and upon these it lives during much of the year. During the breeding season the song of the eatbird is not to be despised, boing somewhat similar to that of certain of the thrushes, whose relative it is.

The nuthatches follow after the woodpecker, and extract the small insects in crevices of the bark of trees. They are very lively and seem to be constantly eating, so that they make up in diligence and appetite what they lack in size.

The sparrow, the most common of all our birls, is generally considered a seedeater, being very fond of weed seeds of all linds; but with the exception of the Finglish sparrow, all sparrows feed mainly on insects in the spring and early summer, and the young are fed almost entirely on insects. The English sparrow is the only real pest in this family.

The finches have strong bills adapted for removing the hard shell of seeds. They, together with other birds of their class, devour immense quantities of the seeds of weeds.

The Baltimore oriole eats grapes in their season, but it also does good by eating the pupa of ecrtain insects which do much damage to trees. It is probable that the benefit is much more than the damage.

The meadow lark, killdeer, and plover, during their stay in the North, foed almost entirely upon insects. Even birds of prey do some good by destroying some small animals that are injurious to plants, such as field mice. 


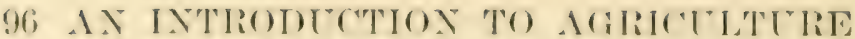

Watch the various birks and learn their foweline habits. It is often posible to gert inte a justion where the fereling of the young may be noted.

75. Attracting the Birds. - In order that wo may have more birkls living about our homes, to help) destroy

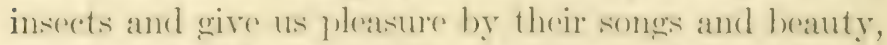
we must povile them with conditions which are favorable to their wases of lifo. Birkls must find suitahle plares for buildine therir nests. The planting of trees and shruls is the rery best way of attracting hirds. ('lumps of shrublury will afford exodlent nestime plates for shy hirds, while the arotehes of trees will he nesed by

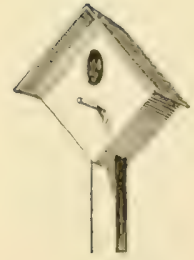

$a$

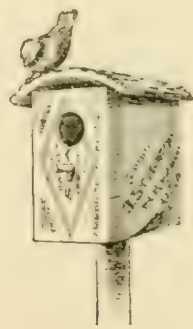

$b$

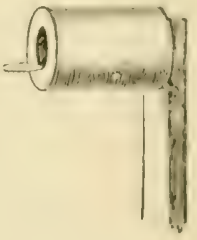

$c$

Bind Houses. $a$ and $b$, made from boxes; $c$, made from a tin can.

robins and many others. The hoys ean easily make

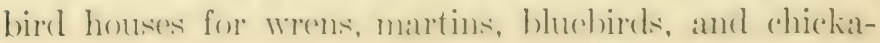

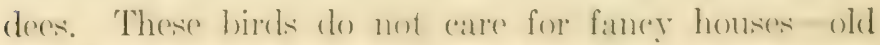
boards are better than now ones for huldine the homses. Mrens will often orexupy a tin can or a small pail which has bern fastemed to a hoard with the colosel end up and a small hole mate in the side. This oprenines shomlel not be orer an inch in diameter for wrens: then the English 
sparrow camnot enter to trouble them. (Old branches that have knot holes of some depth may be fastened on posts, and will often attract bluebirds or chickadees. The barn swallows should be allowed to nest in the barn. If the barn door is kept closed it is a good plan to leave open a small window, or even to make a few holes so that the birds may come and go freely.

Materials may be supplied for nest building. Rohins and orioles often spend much time searehing for threats and strings suitable for use. Narrow strips of cloth will be used in the nest by them and by some other birds, as thrushes and catbirds. It is always interesting to watch the birds as they come to the shrubs to gather these strings and strips of cloth, to see how they will pull them free from the branches and carry them in their bills to their nests. If mud can

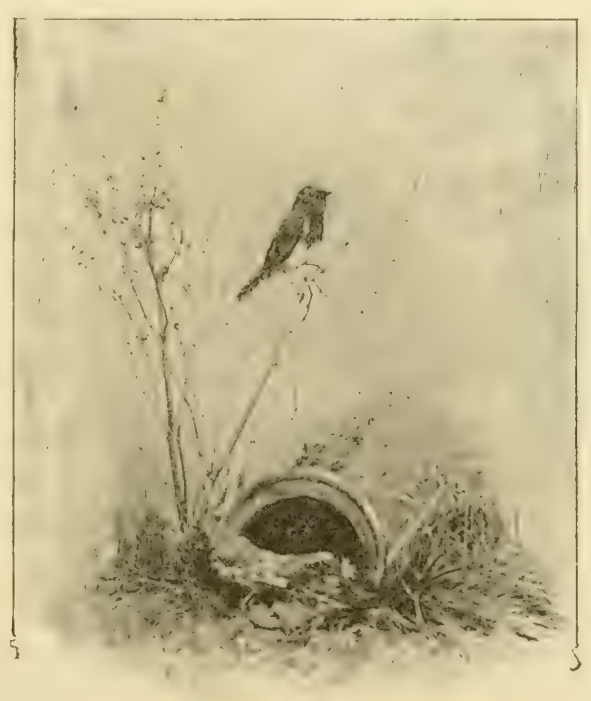

Singing while IIs Mate Buinds. be supplied it will also help the rolnins in their nest building.

The matter of food supply is a more pressing ques- 
tion with the birds than with human beines, for they camnot store away food to any great extent. During the summer days there are insects in abundanee and often seerds and fruits. As a rule the birds prefer the wild fruits if they ean find any near their nests. In the winter the birds that remain have diffieslty in finding food. Then it is that at piece of suet or other fat meat fastened to a tree, or some cracked nuts placed in a shatlow box on a tree, will serve to call the chickader, muthatehes, hairy woodprecker, downy woodperker, brown crepere, blue jay, and binglish sparrow. Often during the breakfiast hour a seore of these birds are seen eating from the suet placed on a tree near the diningrroom window. Many of the number are English spatrrows, but the other birds enene regulaty and talke their turn also. It is just as neersilly, also, to supply (obalashes or sand, which furnish mineral matter repuired by seed-eating hirals to grind their food. By feeding these birels, mere of them will eome in the winter, and they cat great numbers of inseret egers and puplat which have been hidelen in the erackis on the bark of trees. This makes a lessening of the inseret perste the following summer.

Water is essential to hird life. Often our feathered friends sulfer in the smmmer time beratuse they anmot readily find places to drink and hathe. It is an easy matter to place a pan or shallow dish partly filled with water on at post out of reateh of cats. Mlost of you will be surprised at the number of hied visiturs that will eome crery day to serek a drinking fomtain.

If the stray cats of the meighlorhered can be disposed 
of this will serve ats a rery valuable waty of increasing the number of birds alout our homest. Pot cats often eatch birds, "Von pet cats with bells fastened aromod

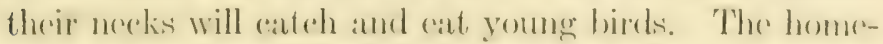
less cats cat large mumbers of birds every yeatr and shendel be disposed of. ('hilderen should be tamght to care for the birds and not to molest them.

76. Toads and Frogs. The toad (am laty no (laim to beatuty, but there is no more useful amimal of its size. One of the most ammsing pastimes is to catch rose bugs and put them down in front of at toarl. The bugs suldenly disappear. The toat's tongue is attached at the fromt of its mouth. It is covered with a sticky substanee, and wan be snapperl ont like at whiphas. There serens to be no linit to the number of bugs a toad cam

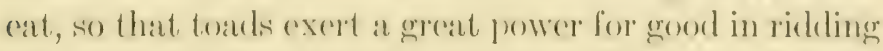
our gardens of destruetive inserets. The ceress of toads are laid in the water, in strings of a jelly-like sulstance. The tadpoles that are hatehed from the cogess are useful in devouring the refuse matter in the pond. Frogs perform the same service.

77. Useful Insects. - You might think from the last rhatplere that all inserets are enemies of the farmer, but sueh is not the case. There are many inserets which help him greatly hy destroying other harmful insects.

One of the usceful inserts is the irhenemon fly, distinguished by having bristles at the end of the abdomen, sometimess sereral inches lome. These are for the purpose of plateing the exgres and serve also ats at drill for piereing whatever the regess are to be placed in. There 


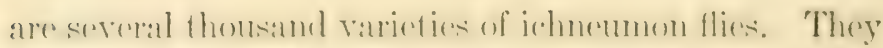

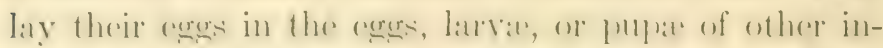

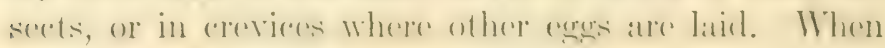

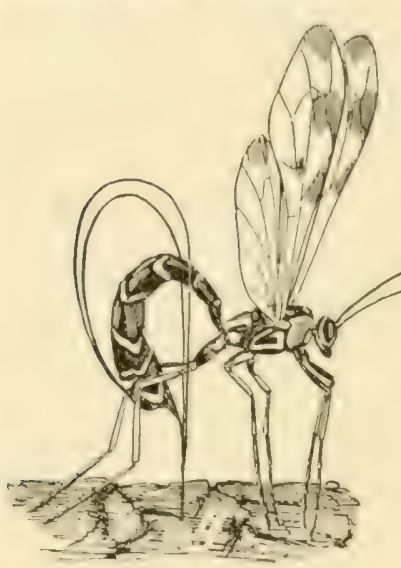

ICHNeUMon lity Prencing TIF BARK OF A 'TREF. the ichmeumon eggs hateh, the young proceed to feed on their host or their neighbors, as the case may be.

The Chalcis flies are minute insects that lay their egres in the egres of the codling moth and other insects. As many as four Chalcis eggis are sometimes deposited in one egr of another insect, which is thus destroyed when the young hateh and feed on it.

Tatrlones are bright-colored hertles that foed on

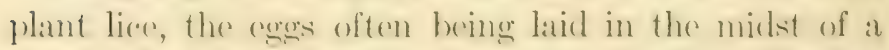

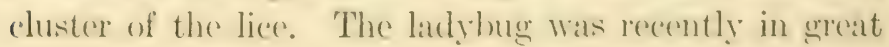

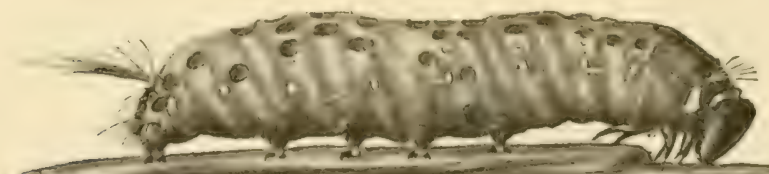

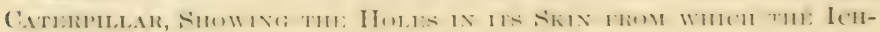
NEUMON Fix PARASITES HAVE ISSUED.

demand to destroy the "errern" heme in the wheat fielels of Kansas. Lien and tiger berthes as their mames would 
indicate, prey upon other inserets, such as eaterpillars and earthworms.

Dragonflies and damsel flies, with their beautiful ganzy wings, are familiar over stagnant pools, where they are beneficial in catehing flies and mosefuitoes. Their egges are often laid under water. The larvie live in water, and even in the pupa stage they feed on water insects and small tadpoles.

Wateh the animals and insects mentioned and notice their habits.

\section{SUMMARY}

Birds are among the farmer's most useful friends.-If it were not for birds, insects would probably strip the earth of vegetation. - Birds may be divided into those that live chiefly on animal food, those that live chiefly on vegetables, and an intermediate group. - Insects are the natural food of many birds, espeecially young birds.-Vegetable feeters help the farmer greatly by eating seeds of weeds.-Miny birds that eat fruit during a small part of the year more than make up for such damage by eating inseets at other times.

Much may be done to make conditions better for the birds, so that more will come to live with us. Bird houses are eatsily made, and food may be supplied in the winter months to induce. more birds to remain in the vicinity.

Toads and frogs destroy many insects and should be protected.

Many useful inserets prey on the hampul inserets and so help to diminish their number.

\section{QUESTIONS A AND PROBLEMS}

I. If inserets lay als many reges as they are said to, why do they not become more numerous? 


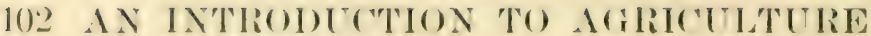

2. What are the three groups of birds, aceording to their choice of food?

3. In what season of the year do birds destroy the greatest number of insects?

4. What is the difference between a toad and a frog?

5. Comting 40 birds to the syuare mile, how many birds are there in your State?

6. Allowing each bird 50 inserts a day for the 120 days of summer, how many insects are destroyed during the summer?

7. Three golden-winged woodpeckers were found by King to have in their stomachs, respectively, 25.5, 220, and 200 ants. Supposing this to represent one day's ration, how many ants would these three birds eat in four months?

8. During an outbreak of Rocky Mountain locusts a marsh wren was seen to aarry 30 locusts to her young in one hour. At this rate, how many would she earry in 7 hours?

9. If there were 20 brools being thus fed, to the square mile, how many inserets would be destroyed in the 75,000 square miles of Nebraska's area?

10. Each locust in Problem 9 weighs 15 grains and there are 7,000 grains in a pound. If each lorust would consume its own weight of standing arops each daty, how much would be saved by the birks, allowing $\$ 10$ per ton for the crops? 


\section{CHAPTER X}

\section{PROPAGATION OF PLANTS BY SEEDS}

78. Seeds.-Already you must have realized that seeds are very important. You have learned how the plant starts its growth from the seed, feeding at first on the nourishment stored there (See. 2). As the production of sced is the object of the plant's existence (Sec. $58)$, let us see now how the seeds are produced.

79. Flowers. - We may regard flowers as the first stage in the production of seeds. Many plants, of course, are raised solely for the beauty of their flowers; but if the blossoms are unpieked you know they will "go to seed." Other plants have flowers which we hardly notice, for we are interested only in the grains or fruits that grow from the blossoms. For example, the ear in its early stage and the tassel of the corn plant are really its blossoms. The flowers of the berry plants and fruit trees are familiar. The clm, the maple, and other trees also have flowers, although you may never have looked closely enough to see them in the spring.

8o. The Parts of a Flower.--In order to see where and how the seed is produced, we must take a flower to 
piocess and loarn its parts. You will motice first a sort of emp where the flower lises feom the strm. This is the colyge. It is somotimes slit into parts. like little leaves, which are ealled sepals. The sepals of most flowers are

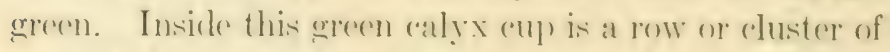
smowy white or colomed leatres, or pelels. forming the corolla. This is erenerally the protty part of the flower which attrates ome attention. In the heart of the flower

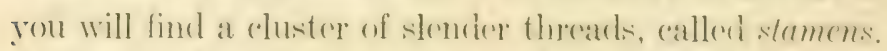

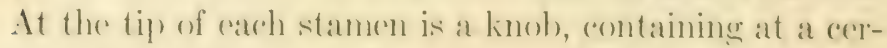
tain time of the yoar fine powder. This fine, powdery substance is ealled pollen, and the knol, is the anther. There is still one more patet of the flower to notier-the part for which the other parts exist. At the very enenter of the flower is the pistil, the seed orean. often there atresereral or many pistils. It the top, the pistil is enlaresed a little to form what is called the stigme. The base of the pistil is the orery, and there the sorels are formed. The part comereting the ovary and the stigma is called the style.

siome flowere of the rose family may be taken to learn these parts. To this family helonge tho alylule, pear, plum, wherry, strawhery, rasplorery, hlacklorery, and roses, so it will he rasy to ohtain a sherimen. Let IIs take the stratwerery. The calyx will he foumd to have five parts, and outsiete of these are fire othere leaflike parts callod breck. Five white potals next alplear, and inside of these are the numeroms stamens, ateh bearing at the top its anther. In the erenter of the flower are foumel the pistils, which are mumeroms and gathered in a clump or head. Fomotimeswe find stawlyery or other 


\section{PIOPAOATION IBY NEETS}

blossoms which lack either pistils or stamens; such blossoms are said to be imperfect.

Not every blosiom eontains all these parts. Sime plants have no sepals or potals on their blosioms. Cer-
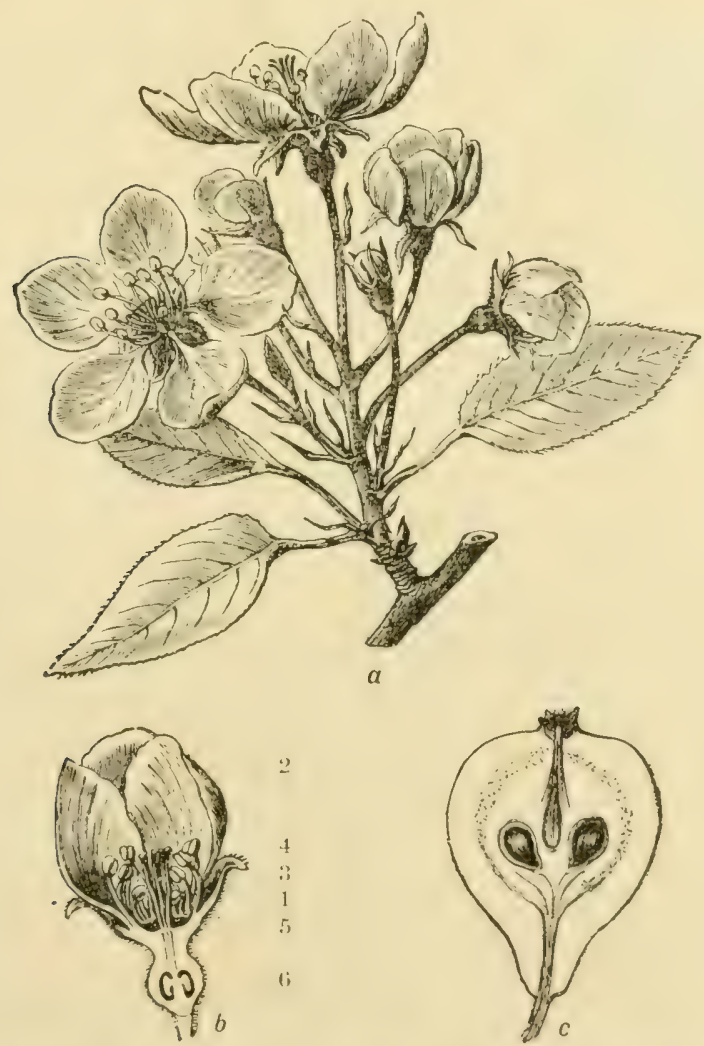

Development of tIIE PEar. $a$, branch of the tree, showing flowers; $b$, section of flower, showing parts; 1, calyx, showing sepals; 2 , corolla, showing petals; 3 , stamens; 4 , stigmas; 5 , styles; 6 , ovary, showing seeds; $c$, ovary developed into the pear. 
tain other plants have stamens and pistils on some of their blossoms, but not on all. Sometimes the stamens are on one blossom of a plant and the pistil is on another blosion of the same plant. Most flowers do not have bracts.

Examine flowers carefully until you can easily distinguish the parts.

81. Pollination.-In order that the seed may be formed in the ovary, it is neeessary that pollen shall fall or be placed on the stimma. At the season of the year when the pollen is ripe, the stigma is in just the right condition to receive it, that is, the stigma is sticky and the prollen will adhere to it. The grain of pollen on the stigma sends a shoot down through the style into the ovary, where it reaches the forming seed or orule, as it is called, and fertilizes it, so that it will grow to a live seed able to sprout and produee a plant. As the anther containing pollen and the stigma (the top of the pistil) are frecuently close together, it looks like a simple act for the pollen to fall on the stigma. But we have just leamed that stamens and pistils do not always grow together in the same blossom or even on the same plant. How, then, do you suppose this fine, almost invisible, powder can be carried from one plant to another?

The breeze wafts some pollen and distributes it to stigmas: but there is another and surer way. Bees and other insects flying from flower to flower are the chief moans of pollination, that is, of transferring pollen from anther to stiema. When they alight on a bloseom they 
may brush on their body some of the pollen and when they visit the next blossom this pollen nay rub off on the stigma. The visits of insects are, therefore, very necessary to the flowers if good seeds are to be produced. To attract them the flower has several devicesits bright color and its sweet perfume, its whiteness and its nectar. The insects always seek the sweet substance which is generally found deep in

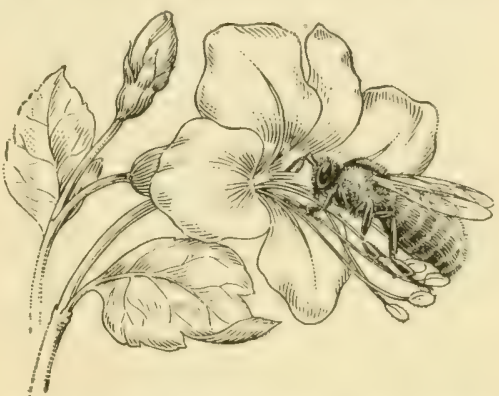

a Bee Gatiering Honex, and Showing How the Pollen can Rub OfF ON ITS BODY ANd Legs. the cup of the blossom, and in probing for it they unawares do their special scrvice for the plant.

82. Cross Pollination and Hybrids. - The pollen must unite with the ovule in the ovary in order that fertile seed may be produced. This grain of pollen may come from the same blossom or from that of another plant of the same kind. When the pollen from one plant enters the ovary of another to produce seed, we have what is called cross pollination. The seed that results from cross pollination may produce a better plant than either of the original or parent plants. The characteristies of the two parents are united in it. In this way new varieties of plants may be formed.

Sometimes we combine the characters of two kinds in a new plant. Such a plant is called a hybrid. Two varieties of apples may be crossed in this way. In such 
rases pollination is non loft fo the rhanew of wiond or hers, but the erosing is dome he hamd. The ynalities most

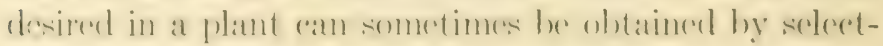
ing carefully, the two parents of a seed.

Il hem pollination is dome hy hand the anthers of one

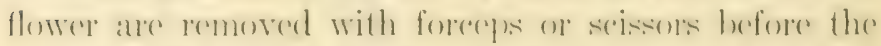

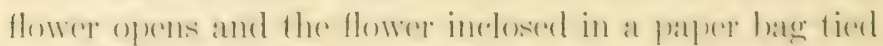

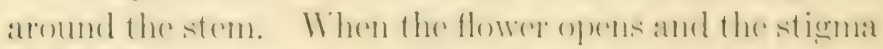
is ready to reerive the pollen, this is obtained from antother plant and appliod to the stigma of the first flower with a smatl hrush or avern with the finger. 'The flower is then covered agenin with the gatere hage, which may he

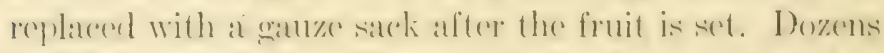
and reven humberls of flowers maty lo thus pollinated in an experiment and the sereds planted and allowed to develope to sece whether they will produce improver plants.

Angenttural experiment stations and private in-

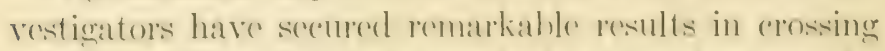
plants. Amonger the most moterl plant hererlers may be mentioned Juther Burhank, of ('aliformia, who has produerel some mustal fruits and plants. ()ne of these is

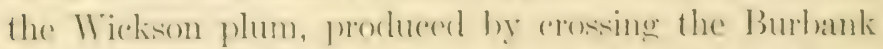
and the Lelsey plums. It eombines the best qualitios of both its parents, havine the shape of the lielsey and

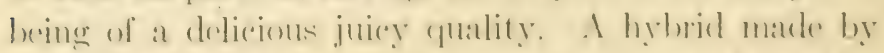

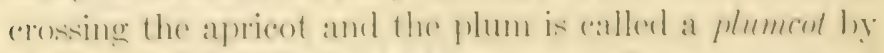

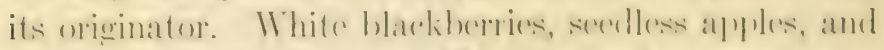
stomeles prumes are other of Mr. Burbank's areations.

83. Propagation of Plants.-The farmer, howerer, is less directly concerned with these special matters of 
pollination than with the simple production of plants, that is, propagation. If no one looked after the planting of seeds and the raising of plants after the seeds sprouted many varieties would disappear entirely. Most plants die after a few years; and even those? which, like the great trees of california, live to be many humeled yeatss old, will eventually die. The farmer makes it his business to see that, as the old plants die, new ones are raised to take their place. The ehief work of the farmer, indeed, is the propagation of plants.

84. Quality of Seeds.-You know that the quality of seed affects the kind of plant that will result. The farmer can get a weak plant or a strong plant, fow fruits or a generous erop, aceording to the qualities of the seced he plants. There are several factors which determine whether the seed will grow well-its age, its maturity, the vigor of the parent plant, and the conditions (moisture, air, and warmth) of the soil in which it is planted. Some seeds will not sprout owing to age or other unfavorable condition. Those that will sprout are said to be viable.

85. Age of Seeds.-Mlelon seceds will grow when tom years old. Onion secels frequently will not sprout if they are more than a year old. Starchy serels, ats rice and wheat, serem to remain viable longer than oily ones, as corn and sunflower.

The following table from Vilmorin's "Vegetable Garden" gives the average period of viathility: 
Duration of Germination Power

\begin{tabular}{|c|c|c|}
\hline & Average Years & Lixtreme Years \\
\hline$\ldots \ldots \ldots \ldots \ldots$ & 6 & 10 \\
\hline Bean, kidney............. & 3 & 8 \\
\hline 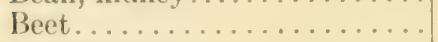 & 6 & 10 \\
\hline 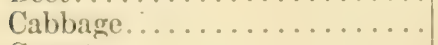 & 5 & 10 \\
\hline 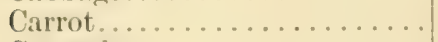 & 5 & 10 \\
\hline Cucumber............... & 10 & 10 \\
\hline Lettuce................. . & 5 & 10 \\
\hline 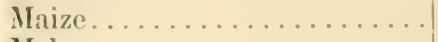 & 2 & 7 \\
\hline Melon................... & 5 & 10 \\
\hline 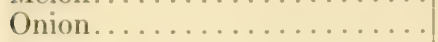 & 2 & 7 \\
\hline 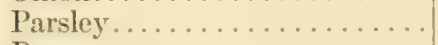 & 3 & 9 \\
\hline 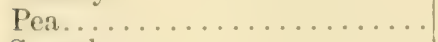 & 3 & S \\
\hline 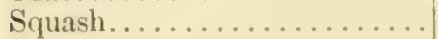 & 6 & 10 \\
\hline 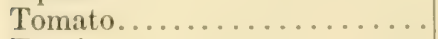 & 4 & 9 \\
\hline Turnip.................. & 5 & 10 \\
\hline
\end{tabular}

86. Maturity of Seeds.--Another condition that afferets the quality of seed is the time when it is talien from the parent plant. If the seed is ripe, or fully grown, we say that it is mature. Some secels will not sprout, or germinate, if picked too soon. Other secels will continue to ripen after leaving the plant, especially if a part of the plant is gathered with them. And there are some seeds, as the tomato, that will germinate if the fruit is but little more than half grown.

It is thought that if immature seeds were used for several generations, it would result in reducing the vigor of the plants. Soeds should be kept in a dry place after being matured to prevent deterioration.

87. Selecting Seeds. - Byy careful selection of seeds much better crops may be secured and plants may be 


\section{PROPARATION BY SEEDS}

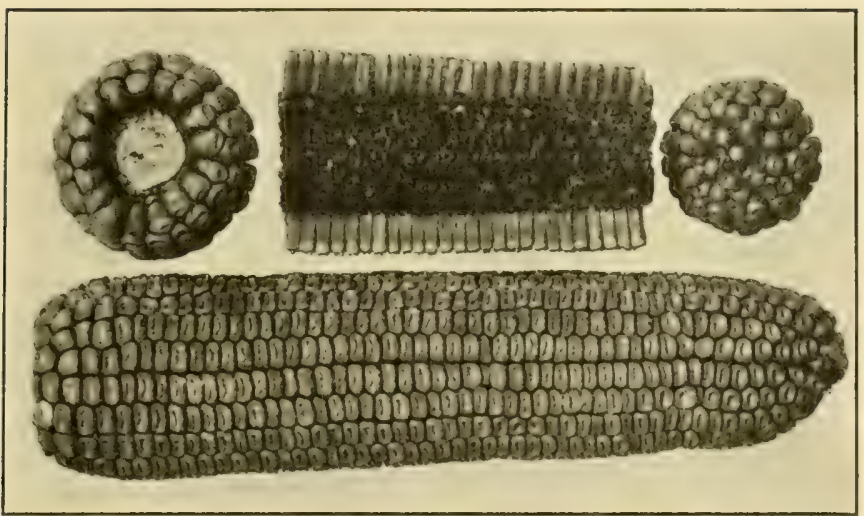

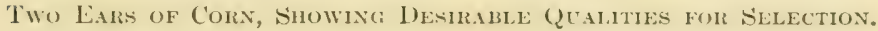

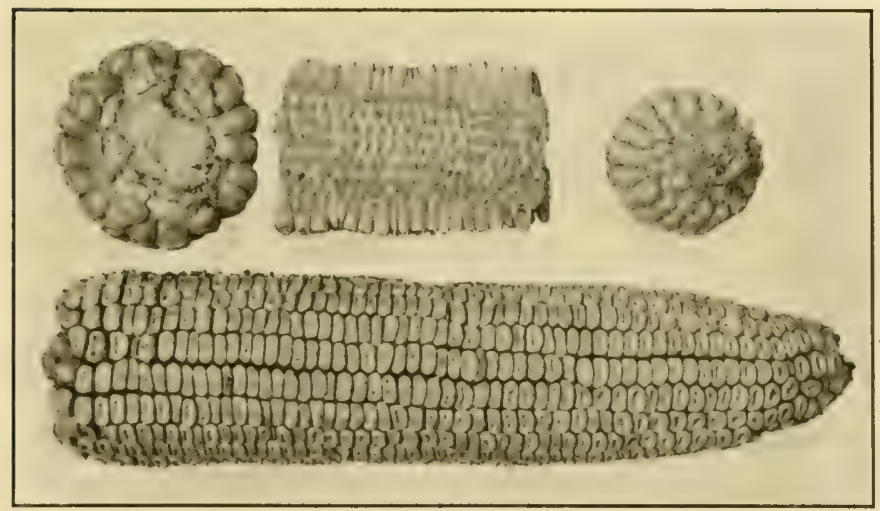

Two Undestrable Ears.

improved in many ways. Great improvement in corn, wheat, and other grains, as well as in many other kinds of plants, has been made and this is largely the result of seed selection. It is not sufficient to select the seed 


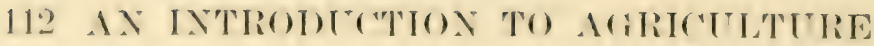

after it has been harvested; neoful selection reaches lack to the errowing erop). In brief, the selfertion of seed corn is as follows: The farmer or breeder exets elearly in mind his isleal. Farly in the fall before the time of harvesting he goes through the fiedd and selerets the stallis of sulperior quality. In this selection he takes aceount of the general vigor of the stalks, wilth of blade, shank of cars, neither too long nor too short, ears at an average height from the ground, number of ears on stalk, strength of bratere roots, size and regularity of the stalk. Then he clowery inspects these solected plants again, and choost's the ears that most nearly meet the ideal he has in mind. The corn from these ars is planted, the kernels from an ear of one stalk in one row and those from an ear of another in another row, and selections are again made just before the harrest. Seed is taken this time from those rows and plants that show the best results in conforming to the ideal. After sereral years of such selecetion and planting a eertain type will beeome fixed. Sometimes the corn from one ear is planted alpart from others in a spuare pateh instead of in a row, as there is then less dariger of eorn from different types of ears mixing by the pollen blowing across.

sometimes it is desirable to change eren the content or eompensition of the seed corn. In this catse analysis is mate of the kernels from seleceted ears to determine the relative amomts of proteid, wil, and stareh, and selecetions made aceordingly. By this means com has been marle to vary from 2.62 per eent to 6.98 pere cent in its oil content, and from 6.9s pere cent to 1.1.1: per cent in protein. Of comrese not all the good qualities 
ean be readily obtained in one type. If carliness is sought size may be sacrificed, and if size is the main quality sought time of maturity may be sacrified. So also, if great size is desired numbers may ineed to be sacrificed. Very expert work is required to produce the proper combination of good qualities; and even then the results may be disappointing.

Selecet an ear of corn from a stalk bearing two fars, and one from a stalk bearing one ear. Plant some kernels from cach some distance apart, and mark the rows for identifieation. Note whether one kind produees stalks with two ears each.

Among the small grains it is well to sclect those that are able to resist drought and smut, those that are early, plump, and will yicld abundantly. It will be no great trouble to sow these in a part of the grain field for several suecessive years, and a better lot of seeds may thus be obtained. The variety of wheat known as bald wheat was produced in this way by a thoughtful man who arecidentally discovered three heads of balel wheat in at ficld of bearded wheat. This was the famous liultz wheat, now one of the best varioties in either America or Europe. England produces nearly twiee as much wheat to the acre as the United states, partly because of more careful selection of seed.

The Burpee bush lima bean was developed from one hill of pole beans which had withstood a frost that killed all the rest of the beans in the fiede. This one hill produeed beans on a dwarf vine. These beans were planted, and seeds were selected from the smallest vines until the variety was established. 


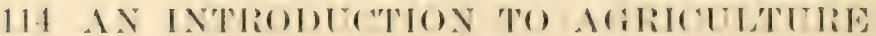

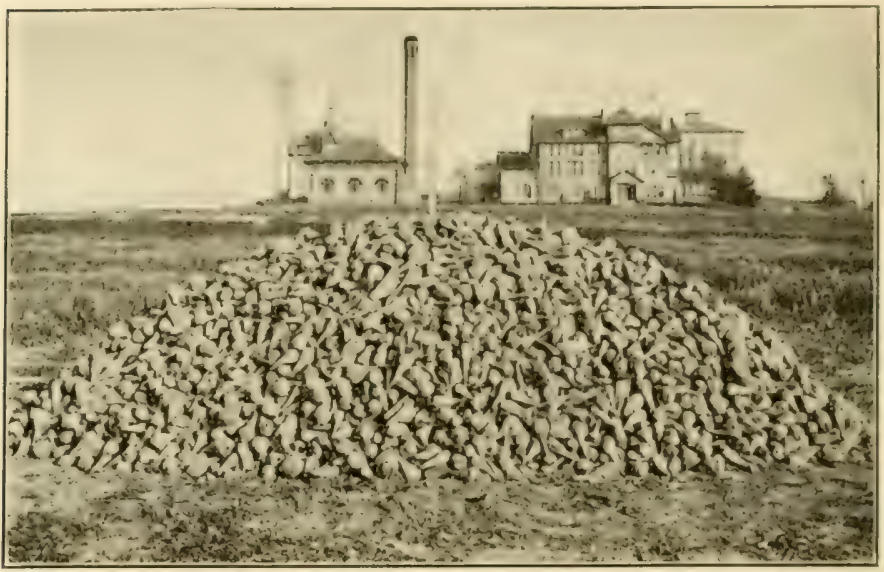

Stgan listers. This pile repmesents tem toms of sugar beets grown on two fifths of an acre of land at the Feperiment station fam at Madison, Wis.

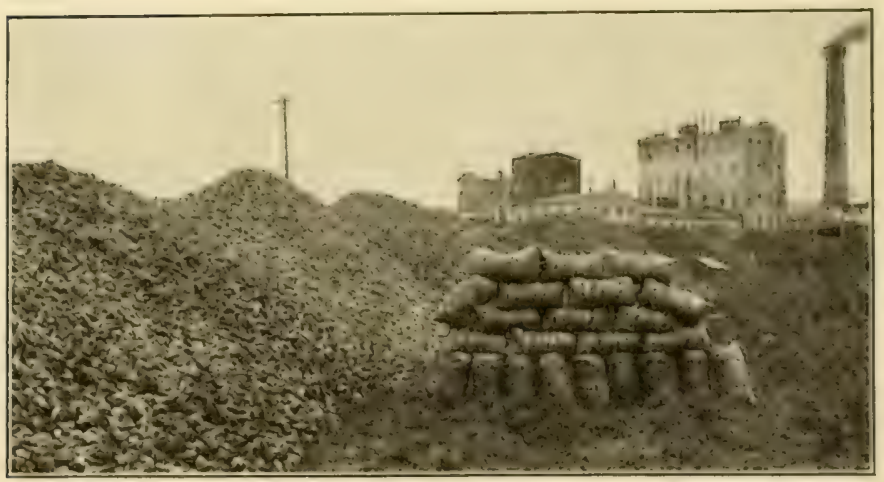

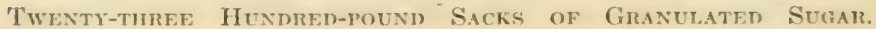
This is the product of the ten tons of beets in the picture above. The University recived a check for $\$ 44.32$ from the Wisconsin Sugar Co. for this shipment. This is at the rate of $\$ 110.80$ per acre. 
By selection of seeds of sugar beets, the amount of sugar contained has been increased from about seven per cent in the original beets to as high as twenty per cent in some types. The average in the best sugar-beet countries is about sixteen per cent. In order to make the selection in this case, a small part of the beet is cut out and analyzed to determine the amount of sugar. Seerls are then raised from the beets which show the most sugar. The small piece cut out of the beet does not injure it for producing seed.

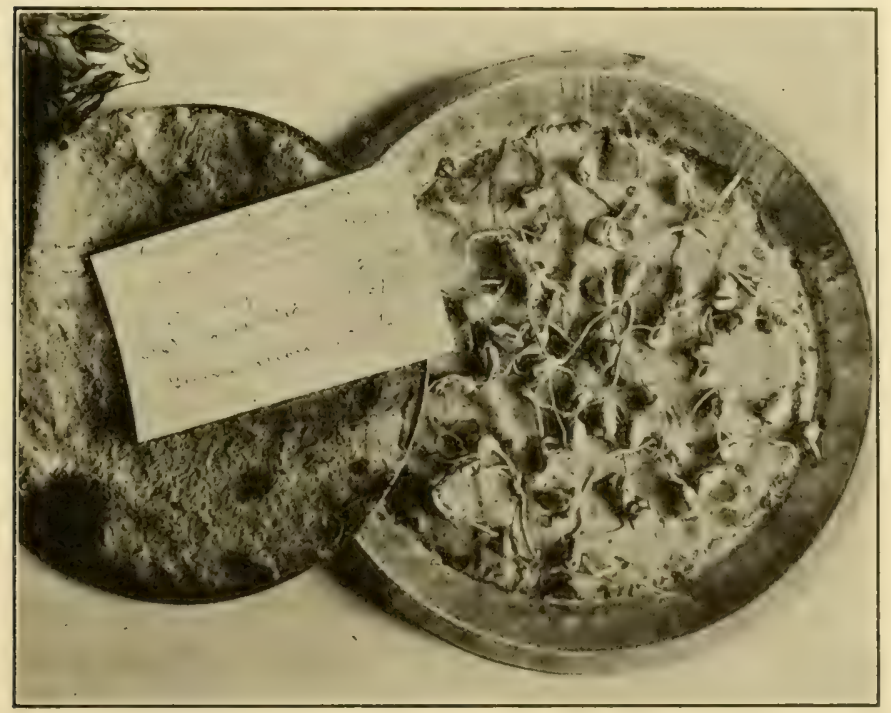

A Convenient Seed Tester for Fammers.

Courtesy of Agricultural Experiment Station, Madison, Wis.

88. Testing Seeds.-Careful farmers generally test seeds before planting. By taking a hundred seeds as 
samples and lettinger them spromt in a sored testor the farmere can juelese of the viability of the serels he is about to plant. If a quarter of these sample serels do not sprout, ho knows what may he expeeted of the whole. It is better to find this out before the sored is somm.

A comsenient form of tester is a tin pio plate with a flat covere, or two pie plates put togerther. Two pioceses of cotton flammel, or similar cloth, are cut the size and shape of the testore. These coloths are wrungere in warm water and one of them is placed in the hottem of the

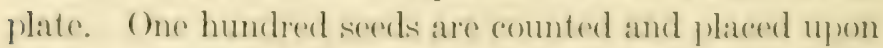
the wet eloth and are covered hy the other eloth, which is pressert down. This is then eovered by the other plate and placed in a wam place. Two or three matehes may be placed om top of the uppere coloth to prevent mold. The eloths should be kept wot and the soeds examined from day to day. The number that sprout is the perecontage of erood seeds; that is, if sixty serels sprout in the lot serecterl, we may eonsider that sixty pere cent of the whole batch are good.

Test some seeds by the method deseribed in feee. ss. If you take 50 secels instead of $10($ ), the pereentage is found hy multiplying by 2 the number that sprout. Why?

\section{Conditions Affecting Germination.-If the seeds}

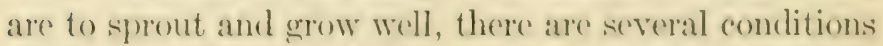
which must be farorable, such as depth of planting, finc serel bed, moisture, air supply, temperature, and nature? of seed case.

The size of the sered determines to a larere extent the depoth of planting. Finall sereds that produce weak 
plantlets must be left near the surface of the ground. Many of the garden seerls should not be planted more than half an inch deep. P'als are sometimes planted several inches deep, so that they will not suffer from drought.

In order that seeds may germinate they must be able to absorb moisture. They will do this better if the soil is eompareted over them. The danger in this is that a crust is thus formed which the young plants must break through. The soil must not be too wet or the seeds may rot before they sprout. If the soil is too compart or too wet the air will be kept from the seel. This will hinder germination, because the soed must have plenty of air. In fields which are under water soon after planting, the seeds do not sprout.

There is a certain temperature which is best for the sprouting of plants. If the soil is colder than this the seeds will not sprout, or will sprout but slowly.

Some seeds, as nuts, have so hard a seed case that something must be done to help release the sprouting plant or it will not germinate. These shells are often hand-eracked or allowed to break by freezing and thawing before planting.

\section{SUMMARY}

All plants have flowers. - The most important parts of the flower, ats recarads plant reproduction, are the ovary and the pollen.-Pollen must fall on the stigmat and penetrate through the ovary to the seed in order to make possibles the growth of the seed. - The sprouting of the seed depends on its age and maturity, vigor of the parent plant, and the condition of the soil. 


\section{IIS AN INTRODUCTON TO AGRITLTULE}

Seeds should be earefully sedected and testerl.--They should he selected early, from the growing plant, not after harvesting. - Different seeds should be planted at different depths, aceording to the size and kind.

\section{QUESTIONS AND PROBLEMS}

I. Why are plants propagated?

2. What is meant by seed selection?

3. Why is selection necessary?

4. What is the use of the pollen?

5. How maty bright colors of the flower or strong odors be useful to the flower?

6. What are the conditions that affect germination?

7. The annual wheat crop of the United states is about five hundred million bushels. If this could be increased 2 per cent by seed selection, what would the addition be worth at S0 cents per bushel?

8. How many agrieultural experiment stations would the increase support, at half a milion dollars a year for each station?

9. If grass seed costs 10 cents a pound and is 20 per cent weed seed, what is the real cost of the gratsis seed? Would it be cheaper to buy a clean seed at 12 cents?

Io. If one day extra were spent by every farmer each yoar for five years in selecting and caring for seed corn, and the yield thereby increased 100 bushels, would it pay?

I I. It costs about $\$ 30$ to grow an acre of sugar beets. What would be the profit per are of beets grown under conditions similar to those in the illustrations on page 114 ? 


\section{CHAPTER XI}

\section{PROPAGATION BY CUTTINGS AND OTIER MEANS}

90. Other Methods of Propagation.-In propagating by seeds we produce new plants by putting into the ground parts of the parent plant specially ordained by nature for this purpose, without injury to the parent. Another method of propagation is by cutting off a part of the parent plant and letting that grow separately. These removed parts are spoken of as cuttings, and the process is known as propagation by means of cuttings. In other cases a part of the plant may take root and grow into a new plant without being entirely separated from the parent plant. This is done by bending down a branch and covering it with soil; it is ealled layering. In still other cases, plants may be propagated or established plants entirely changed in many of their characteristics by grafting and budding.

91. Growth from Buds.-In these other methods of propagating plants the development of the new plant comes from buds instead of seeds. Every live stem or branch has buds along its sicle: and one, at least, at the end. When the leaves fall the bud at the base of each leaf remains, and the next spring it opens into new leaves. With many kinds of plants, if a piece of the stem is 


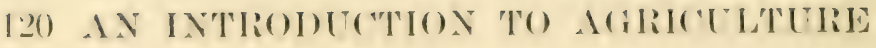

planterl in soil, roots will grow from the huds and a new plant will be formed. Some plants, as the strawhery, send ont from their main stems rumers which ond in a strong buel. These buds take root and thus the original plant makes many new ones. One parent may form thirty or forty young plants in the course of a season.

92. Cuttings. -To propagate a plant hy euttings, we remove a part of the stem that has at least one good burl. This piece is put in water or moist earth. After its roots are well started, it may be earefully removed to the place where we want the plant to grow.

Many plants are propagated by cuttings. A few, as the beconia, may be propagated from a leaf rooting either in water or in damp sand. But plants are more frepuently developed from thrifty shoots. This is the common method with geranium, heliotrope, verbena, nasturtium and others. The shoots or ruttings are divided so that there are two or more joints or nodes to each entting, which is then buried in moist sand and kept warm by artificial heat if necesiary. If there are leaves on the shoots they should be trimmed or remeverel to reduee the evaporating surfice. When the roots are an inch or so loner, the euttings may be transplanted into small pots, and from there into latrer ones as the roots fill the pots. Hard-wood cuttingre, such as currant, gooseberry, grape, and flowering shrubs, are generally made in the fall and packed in green sawdust or damp sand. They may be started in the house by February or Mareh or lie until spring and be planted in wollprepared soil. Each eutting should have two or three nodes, and when planted one node should be above 
ground. They are generally put into the ground in a slanting position and the soil firmly pressed about them.

Potatoes, sweet potatoes, and sugar eane are nearly always propagated from cuttings. A potato is a swollen underground stem and when it is cut in pieces to plant we really use a piece of a stem or cutting.

\section{Layering.-} In some plants buds may be made to root without being cut from the plant. A slender branch or stem is bent down then covered with soil.

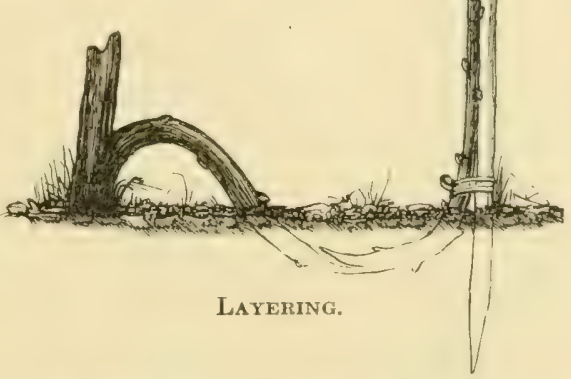
From the buds in this part of the stem roots will grow. When they are well established the stem is cut off below the new roots and we have a new plant.

Try the experiment of layering such bushes as gooseberry, raspberry, blackberry, and currant, and also grape vines.

94. Grafting.-Crafting consists in setting into a tree a little twig from another tree, so that it becomes part of the new tree. The tree on which the grafting is done is called the stock, and the twigr set into it is a scion. Grafting is done to secure a different linel of fruit on a tree, to preserve and multiply special varietics, to hasten flowering or fruiting of seedlings, to replatee lost branches, or to change the size or shape of a trees. All the fruit trees in America are grown cither from buds 
or crafts as they do not come true from sered. An apple tree hearing poor apples hy suceessul errafting may he marlo to bear a coorel variety. Hoalthy twigs from a tree hearing the desired fruit are made to grow into and become a part of the poor apple tree.

In the case of ayple trees, for (xample, the secions are cut from a desimble tree in the fall and kept in a dry,
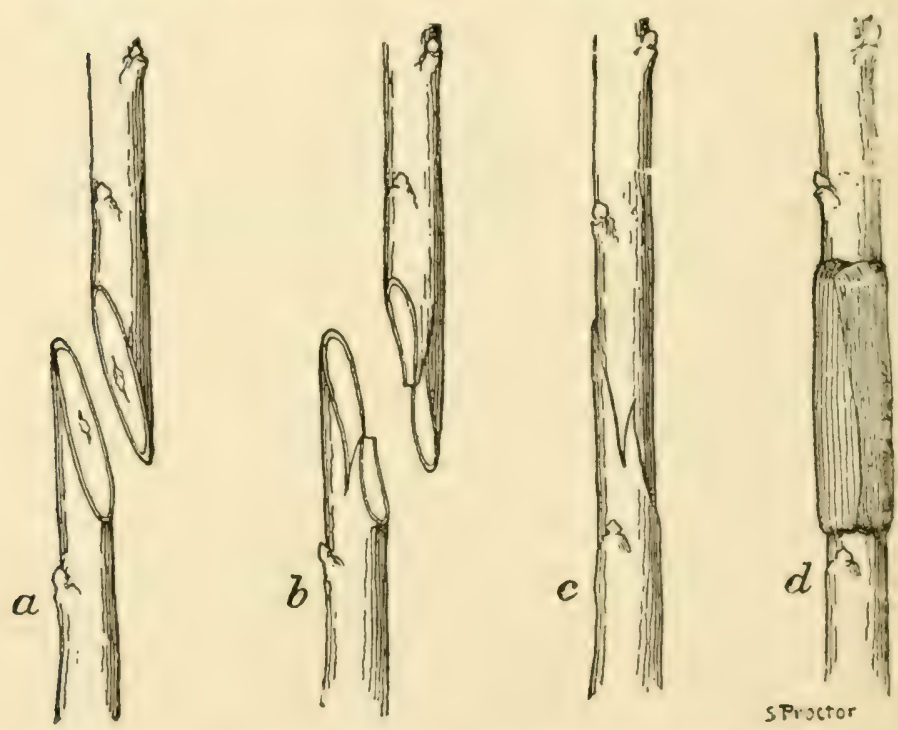

Graftixg. $a$, splice graft; $b$, tongue graft, parts separate; $c$, tongue graft, parts united; $d$, waxed paper applied.

cool place over wintere. In the spring they are set into the stock where desired. A small hranch, gerhaps theee quarters of an inch or larerer in diameter, is sawoel off and the stub split with a kinfe. The seions are whittled wedge-shaped and slipped into the cheft in the stock. 
In this way stock and scion are spliced. Just under the outer bark is a thin, soft layer called the cambium. It is the living and growing part. Care must he taken to have the cambium layer of the scion come in contact with
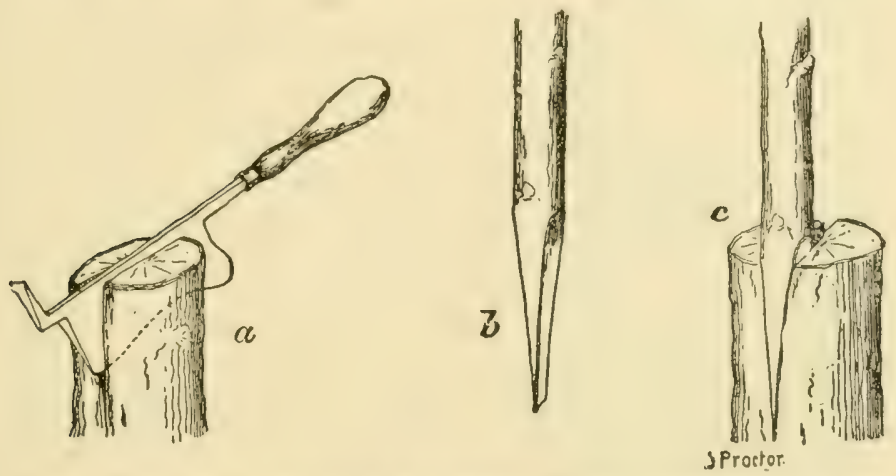

Cleft Grafting. a, splitting the stock; $b$, scion prepared for insertion; $c$, scion inserted.

the same layer of the stock. The freshly eut parts are then covered with grafting wax to keep out air and moisture. Generally two scions are inserted into one cleft and after they are well started one of them may be cut away.

Root grafting, as well as stem grafting just described, is a common practice.

Get some scions from a good apple tree and practien grafting. Make some grafting wax from the following formula: Melt one part beef tallow, two parts beeswax, four parts common rosin, all by weight. Pour into water, and when it is rool enough work with the hands as with molasses candy. The hands should be greased with lard or vaseline. Make up into rolls and cover with paraffined paper or lay on a piece of glass. When 


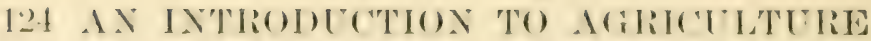

wanterl, if may be platerel in warm water to soften. For use in waxing eloth the beeswax maty be omited or one half more tallow used.

95. The Necessity for Grafting.-. It is neersary to proparate fruit trees and some other plants hy hucling and grafting rather than by seeds. The trees have not beren raisod from the seed enoum generations to eme "true." For exammle, if all the sereds of a Baldwin apyle tree comlel be planted and come to mature trees, it is possible that one or more of the trees might yiedel Baklwin apples, lut the great majority would produce fruit like their wild ancestor, or at least very umlike the Baldwin from which they eame. This is also true because trees have their hlossoms fertilized hy inserets from other varietios of trees and this wombl tend to produece mixed secols. I far surer way, therefore, to gret what is wantod is to craft from a good Baldwin apple tree. The trees which nurserymen sell are raised from serels. When the one-or two-yoar-old seredling is about the sizo of a lead penceil it is (lue up) and ("ut off near the root and a seion from the desired trees erafted into the root part of the seedline. The root may he divided so that three or four stockis may he marte from a single root. In some cases dozens of seioms are crafted into a grewn tree and when they are firmly established the other parte of the tree are cut away so that the entire tree is changed.

Giafting is acterally done in the smring just hefore growth starts. The scions are ent in the fall and kept in a cool cellar so that they will not start wrowing too carly. It would not do to have the seions start to grow 
before the branch into which they are inserted is ready to provide sap for them.

Root grafting is generally done in winter and the plants stored as directed for the scions.

96. Budding.-The process of budding consists in inserting through the bark of a young tree a single hud cut from another tree. The desired bud is cut off with a sharp knife and is inserted in a T-shaped cleft made through the bark. The wound is then covered with strips of cloth which have been saturated with melted grafting wax.

In budding and grafting it is necessary that the stocks and the trees from which the buds or scions are removed be closely related. For example, an apple and a crabapple can be grafted on each

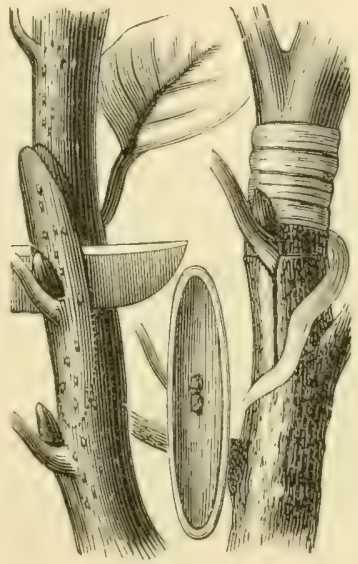

BUDDING. other, but not a peach on an apple. Ordinarily grafting is preferred for certain kinds of fruit and budding for certain other kinds. Apples and pears are grafted. Peaches, plums, cherries and apples are budder. All that part of the tree above the bud or graft partakes of the nature of the tree from which the scion was cut. 


\section{LO6 AN INTRODUCTION TO AGRICLLTULE}

\section{SUMMARY}

Propagation may be aceomplished by means of ruttings, layering, erafting, and budding, as well ats by seerls.-In these methods the new plants grow from buds insteat of from seeds.Fruit trees must be propagated by grafting and budding because they do not "come true" from seeds.

\section{QUESTIONS}

I. What two general methods of propagating plants are there? Why?

2. In erafting, why must the cambium layers of the scion and the stock come in contact with one another?

3. How are carnations, roses, geraniums, and begonias propagated?

4. Which is the sure mothod of propagating fruit trees, from seeds or from grafts? Why?

5. What advantage will a young potato plant propagated from a piere of potato have over a plant grown from the seed?

6. Why is the spring at erout time in which to do grafting:?

7. Why might a rainy time when trees are in blossom prevent a good crop of fruit?

8. Why is layering a more sure method of propagating than by a detached cutting?

9. Why is the spring the best time for erafting?

ro. Why is it best to removesome of the leares from a cutting or scion? 


\section{CHAPTER XII}

\section{THE FARM GARDEN}

97. The Importance of the Farm Garden.-In the farm garden can be raised, with little outlay, a great variety of good, healthful food for the farmer and his family. Many farmers have thought they were too busy to attend to a vegetable garden. Many eity folks in much poorer circumstances than the average farmer have had a greater variety of fresh vegetables and fruits on their tables than he. But farmers are coming to realize that it is a good investment to set a good table; that it is very important for the health of the family, and especially of the younger members, to have a generous and varied diet, and so of late years the garden has come more and more to be considered an indispensable feature of the farm.

98. Position and Soil for the Garden.-The garden should be in a warm, sunny place, sloping to the south if possible, so that the plants may grow rapidly. Most garden erops are better if they make a rapid growth. The best soil for the garden is a light sandy loam (Fece. 8). By proper treatment and cultivation almost any soil can be made suitable. The soil should be enriched with well-rotted manure. 


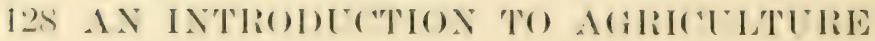

The garden should not be laid out in square beds or little patches as was formerly the practice, unless it is to be taken care of by a gardener. It should be long and narrow, or at least of such shape that things may be planted in long rows and catsily cultivated. With this arrangement the garden can be cultivated by a hand wherel cultivator or by a plow or other implement drawn hy a horse. Iforse cultivation in the garden pays, and if it is to be practiced, the nearest rows should be twenty-four to thirty-six inches apart. The spareing of rows may vary from thirty inches for small stuff to four feet for melons and cight feet for hackberries.

99. The Care of the Garden.--One diffieulty in the way of having a good garden on the farm is that it must be attended to in the early spring when the farmer is straining every energy to get the main erops started. But the garden is a place where every member of the fanily can help, and it requires comparatively little labor and time. The soil should be thoroughly tilled in the spring ant enriched if need be and a good seed-bed prepared, as we have already learned (Fee. 23). Teeds must be kept out by frecpuent use of the hoe or eultivator, operations which will also serve to keep air and moisture in the soil (Sec. 22).

roo. Desirable Plants for the Garden.-The aim in (hoosing plants for the garden should be to have such a variety that there will be a constant supply for the table from early in summer until late in the fall. It is possible sometimes to plant early receretables and later ones in alternate rows. The early ones will be out of the way before the late ones need erround to spread over. 
In this way, if there is need to economize space, radishes might alternate with parsnips and be out of the way before the parsnips are very large.

A garden should be arranged so that it may be easily cultivated. Everything should be planted in rows; and if the garden is large and a horse is to be used, the closest rows should be from twenty-four to thirty-six inches apart. The distance between rows should vary from thirty inches for small stuff to four feet for melons and eight feet for blackberries.

Among the earliest plants that a garden will yield are lettuce and radishes. Lettuce seed sprouts very easily and quickly. It may be planted in rows twelve inches or eighteen inches apart. The seeds should be covered half an inch deep and the young plants thinned out so that they will be one or two inches apart. For head lettuce the plants should not be left nearer together than about eight inches. Radishes are generally planted in double rows six inches apart and eighteen inches from the next double row of plants.

Beets for early greens may be planted in rows twelve inches apart, but if the roots are wanted the rows should be eighteen inches apart. The seeds should be covered about an inch, and the soil pressed firmly over them. The plants should be thimned out to three inches apart if raised for the tops, and six to ten inches apart for early and late roots.

Peas are planted several times in a season. Small varieties that do not need bushing may be planted in double rows, twelve inches apart and thirty inches from the next double row of plants. "Champions" and 


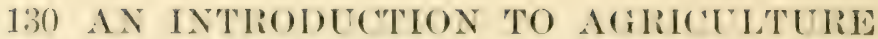

other large bushed peas should be in rows three feet apart. l'eas should be planted deep', cren as much as four inches.

sweet com should be planted at intervals of two weeks up to the middle of July. In this way it is possible to have table com during a period of six weeks or more. The row may be thirty or thirty-six inches apart. Some persons plant in hills alout the same distance apart each way, and others in drills, the plants eight or ten inches apart in the row.

Bush lima beans and string beans are planted in rows eighteen inches apart, and the plants should be thimed so that there are three or more inches between them. P'ole beans are a good crop where poles can be obtained.

Cucumbers and squashes are planted in hills, about three or four plants oerupying an area five feet square. The hill should be dug out and several forkfuls of manure should be put in the bottom and then covered with soil. Cueumbers enough for a small family may be raised in the following way: Dig a hole dece enough to bury a barrel; fill the barrel with horse manure; cover it about six inches deep with fine soil, and plant. Allow a half dozen or more plants to grow. Leave the eenter of the hill open for the purpose of pouring in water. The manure must be kept saturated all summer. A circle ten feet in cliameter will be needed for the vines.

Tomatoes are set out in rows about five feet apart and should be kept well cultivated.

Carrots, parnips, and celery may easily be grown in the garden if clesired. Celery for early use is planted in 
the house and set out in trenches in midsummer. Later it is banked up with boards and earth to bleach it. For a late crop, it may be started out of doors.

Asparagus is a perennial and must be set out where it will be undisturbed. It takes several years to get a good asparagus bed, but afterwards the plant gives very little trouble. Salt is used as a fertilizer for it: One should cease cutting the asparagus when the stalks come up as small as a lead pencil.

Strawberries, raspberries, blackberries, currants, and gooseberries are grown from plants which are generally bought of nursery men. In setting out a strawberry bed, more than one kind of plant should be chosen in order to secure good results. On some varieties of strawberries the blossoms have no stamens. These plants will not produce fruit unless strawberry plants having perfect blossoms are growing within a few feet (Sec. S0). The strawherry plants are easily taken care of and nultiply rapidly. They bear fruit the next season after they are planted. The other berries mentioned are hardy plants and are valuable additions to the farm garden.

The best experiment on this subject is to make and care for a garden. If it is your first attempt, do not try to raise many things. A half dozen things well cared for are enough. Lettuce, radishes, beets, peas, corn, cucumbers, make a good list to start with.

\section{SUMMARY}

The garden is important beeause it furnishes the farmer a variety of food at little cost.-The farmer should see that the soil is right and should enrich and till it thoroughly.-The depth 


\section{AN INTROTUE'TION TO AGRICILTTRE}

of planting the seeds, distance between the rows, and the thinning out of the young plants should have careful attention.-The garden should be started farly and planted with such crops

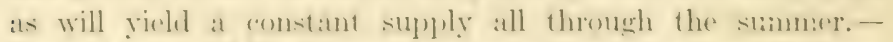
verevtables should be phanted in rows, not in patehes, for ratse in cultivation. 


\title{
CHAPTER XIII
}

\author{
FARM CROPS
}

Ior. Hay and Grass Crop.-Probahly the most important crop, and certainly the one occupying the largest area in the United States, is the hay and grass crop. Although a very great number and variety of grasses are grown throughout the country, the principal ones used for hay are timothy, orchard grass, red top, and June grass. In addition to these may be mentioned alfalfa and the clovers. No farm crop recpuires more ureful judgment on the part of the farmer.

This judgment relates to the kind of soil suitable, the kind of grass best adapted to his use, the proper fertilizers, the best time to harvest and the proper curing and storing. Seareely any other erop) is so liable to injury in harvesting as the hay (rop). Some varieties of grass require a heavy, moist soil, while others will do well on a soil that is dry. If the hay is to be fed to horses it should be coarse like timothy and many would say, free from red clover. Cattle may be fed finer hay and clover. The kind of grass will also determine the kind of fortilizer to be used. Isand fertilized heavily with harnyard manure will produce a good (rop of timothy, while, if clover is desired also, it is a good plan to substitute 


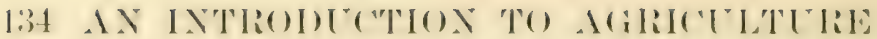

muriate of potash for some of the harnyard manure. The time to harvest hay depends upon the kind and the use to which it is to be put. Timothy should be allowed to mature, while some others are eut before maturity. While the tempitation is to dry the cut grass quickly by constant stirring and exposure to the sun, the best authorities now advocate slower drying with sufficiont exposure to the air to prevent fermentation. Such hay will be found to be lesis tough, of better flavor, and more nutritious. Haying is now done mostly with the aid of machines, the four prineipal ones heing the mower, the tedder, the rake or the loader, and the horse fork. The tedder is not so much used as formerly, at least in some sections.

102. Alfalfa.-This forage crop has increased very rapidly in popularity during the past tem years. It is a decp-feeding plant. The roots of en go into the soil ten or twenty feet, and sometimes even deeper. It will not do well where the subsoil is heary and not woll drained. Alfalfa is a good hay crop, but it may be used for pasture also. It should he cut for hay when it first begins to blomem. Care is necessary in hambling it when dry that the leaves are not hroken off, as they contain the most nourishment for the stock. Three to six euttings of alfalfa may be made in a single seation after the plants have beeome firmly estahlished. It usually takes about three years for the plants to develop their root system fully. Then the field may be mowed for many years if a little fertilizer containing calcium, potassium, and phosphorus is adcled. The alfalfa will be able to supply itsown nitrogen, as explained in the previous chapter. 
ro3. Clovers. - In Chapter VI the clovers were considered with regard to their effect on the soil. Clovers make excellent forage for stock and are so used in all parts of the country. Clover hay requires careful drying or it will not keep well. Red clover is most commonly raised in the North. Timothy or other grass seed is usually sown with it. It is best cut before many of the blossoms tum brown, because the leaves will fall if it is too ripe. Crimson clover seems to thrive better in the South, and may be sown in the fall and used as a (over erop). If sown in the spring it will mature late in the summer. Crimson clover does not seem to do \$o well in the North, as the winters are too cold. White clover is used with grass seed for pastures.

ro4. Corn.-Corn is the second crop in importance in the United States. It was found in America when the first explorers came. It was then known nowhere else, but now it is raised in all parts of the world where it will grow. It requires much sunshine and warm weather and is therofore grown in temperate and subtropical countries. It is used for feeding stock, for human food, and for making starch and whisky. Among the tyos of corn may be mentioned flint, dent, pop corn, and sweet corn.

Corn requires a light, rich soil and does not do well on a heavy soil. There should be much humus present. If planted on sod, the ground may be plowed in the fall and thoroughly cultivated. This is not good practies in the South, however, hecause of the heavy winter rains. Corn is planted in hills three to four feet apart or in drills three feet apart. The plants in drills should 
be eight or tem inches appart. The seeds should not be sown until the ground is warm and danger of frost is over.

Just before the plants come up, the ground may be harrowed with a light, fine-toothed harrow to break up) the crust so that the plants may more easily push through. This also kills weeds. The ground is sometimes dragged with a light harrow eren after the plants are up, eare being taken to hit as few plants as possible. The field should be cultivated as often as necessary in order that the weeds maty not get a start, and to preserve a surface mulch. This should be done as soon as possible after each rain.

When raised in large quantities, eorn is now planted and harvested by machines. Some seeders are so ar-

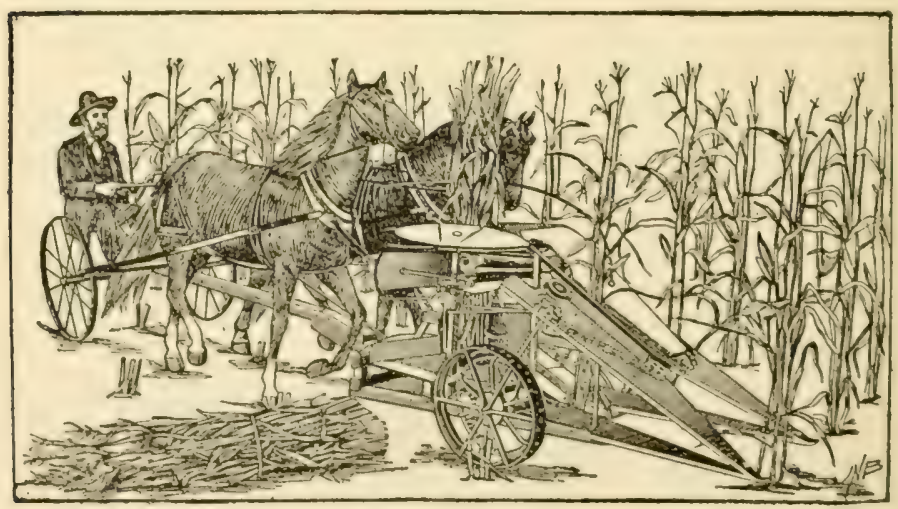

Vertical Corn Harvester.

ranged that they plant the eorn in hills equally spaced si) that the field may be cultivated both ways. More 
of ten the corn is drilled in. The harvesters eut the corn and bind it in bundles to be picked up and starked by hand.

In many places the corn, stalks and all, is cut up and packed in silos as green fodder to be fed to the cattle through the winter. Sometimes the ears are picked off and only the stalks cut up for the silo. A silo is a large, air-tight pit or room where the material keeps moist and fresh. Corn, or other forage crops, put up) in this way is called ensilage.

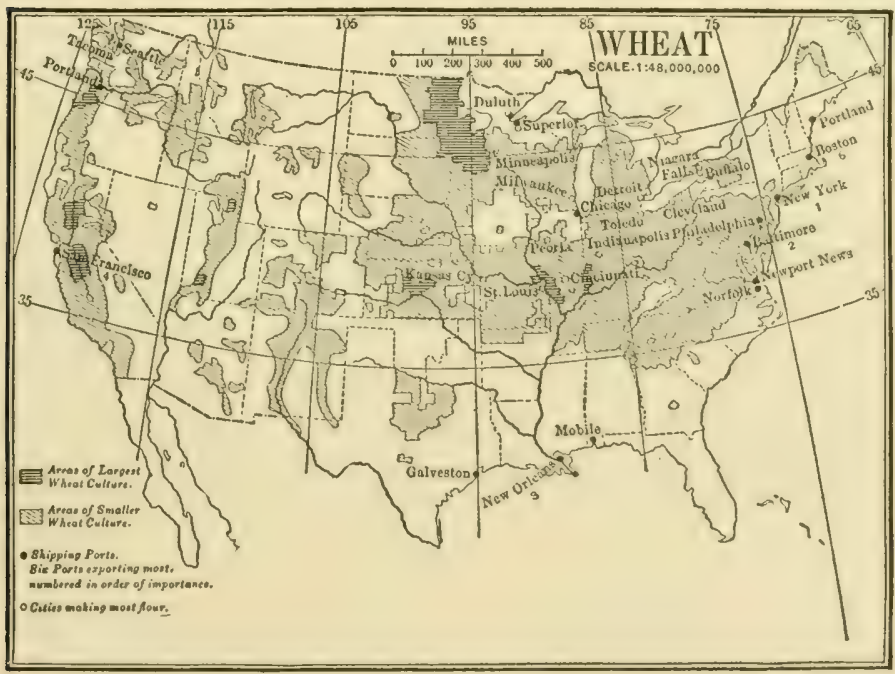

Map Showng Prodiction of Whist in the Linted States.

105. Wheat and Other Grains. - Wheat ranks next to corn in importance. Oats and harley, though following eotton in the value of the erop, may properly be discossed with wheat. There are sereral variet ies of wheat, 


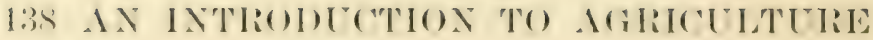

as spring whoat and winter wheat, white, red, harel, and soft varieties, and heareled and bald varieties. The territory for radising wheat in the Inited states is shown on the accompanying map.

The gromed for wheat, oats, and larley should be rich and mellow, hut it need not he as light as for corn. Experiment and farmers experience show that the yiedd of wheat is determined chiefly by the supply of nitmeren

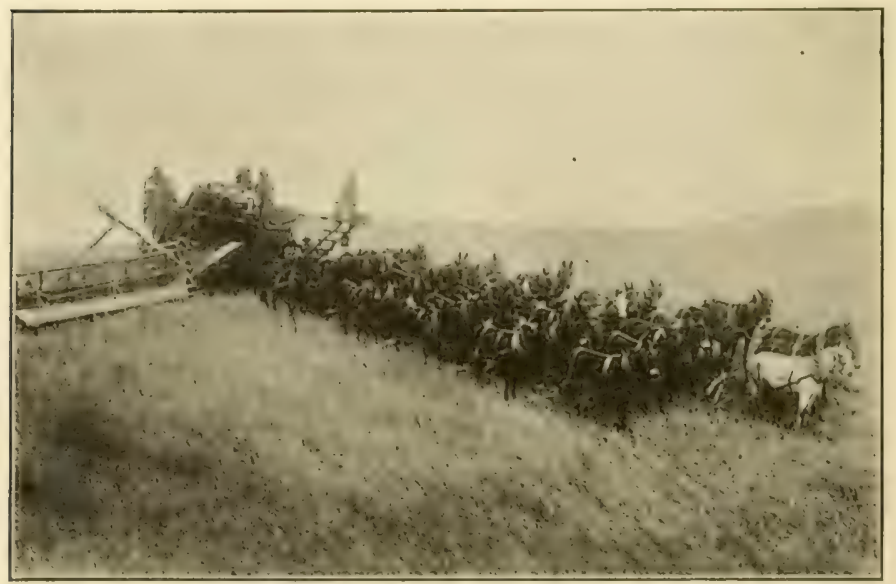

Wheat Hanvesting Machine. (Horse power.)

in the soil or in the fortilizer mased. Mith harley nitrogen is also essential, hut phosphoric acid has an equally markerl efforet. Whoat has a long growing scason and therefore has an opprortunity to get plenty of food. These three crains should all be planted near the surface of the eroumel. It is their hahit to "stool" or send out a bumch of roots from a joint just helow the surface, and later the part of the root helow that point dies. If the 


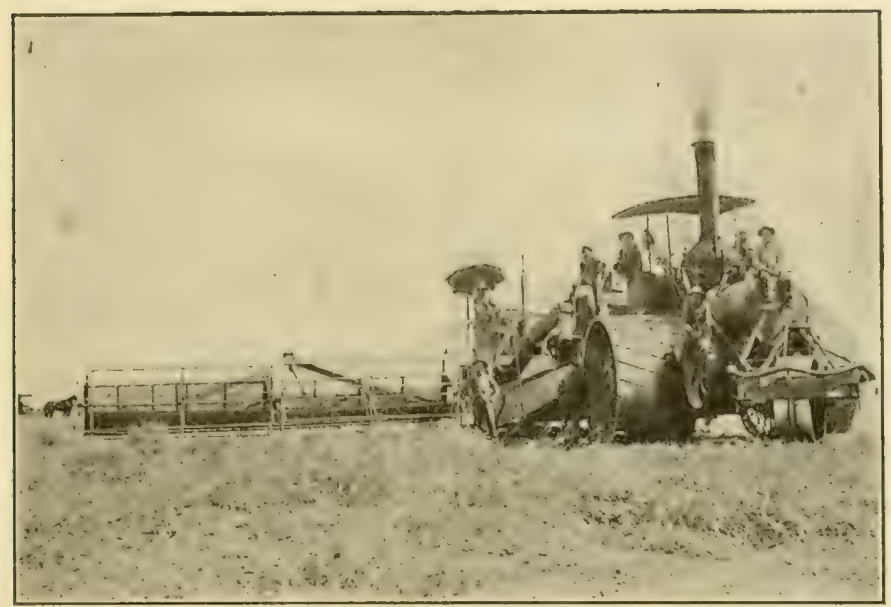

A 50-Horse-power Combined Steel Harvesting Machine and THResher. (Steam power.) Front view, showing the wheat being eut.

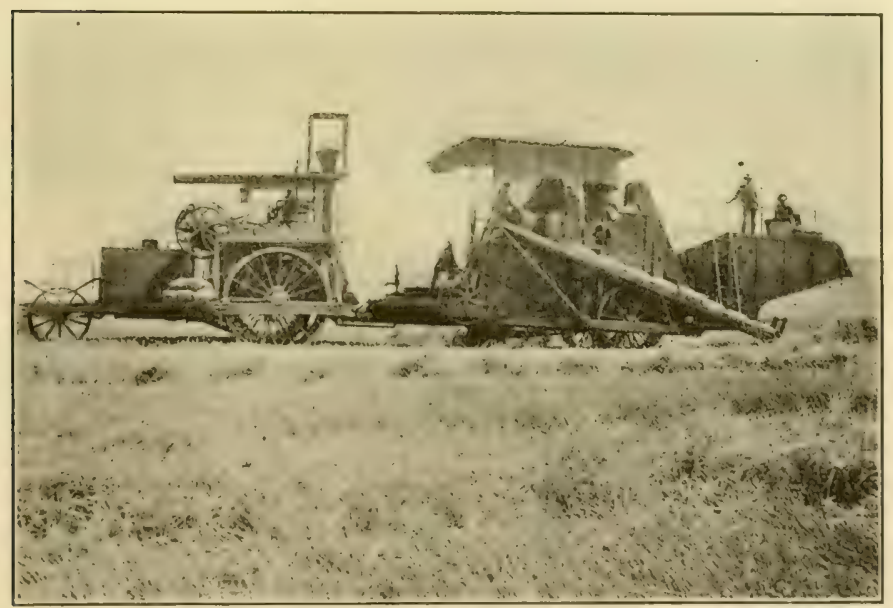

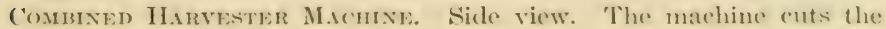
wheat, threshes it, and delivers it ready sacked in one continuous operation. 
plant must foree its way up very far before it stons, it is weakened; henee the neeresity for planting near the surface.

('ertain experiments have shown that it pays to haryow these grains when a fow inches high, for while a few plants may be destroged, the vigor of the others is increased. Weeds are

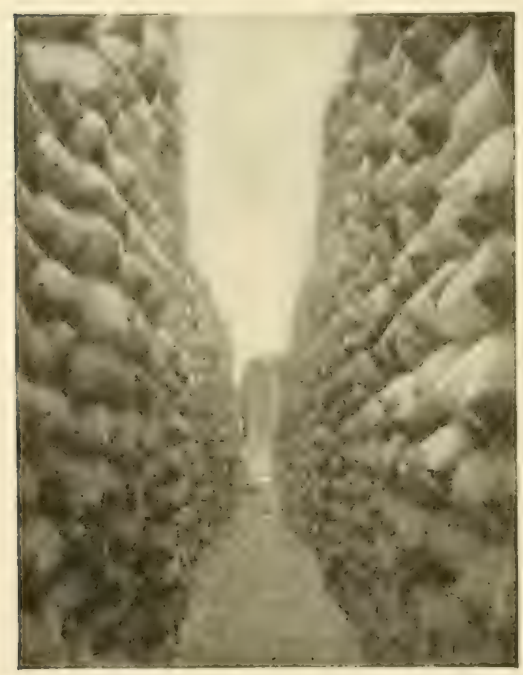

Expont Whimat ax Bars. Two humberl and fifty thousand bushels of wheat at Portiand, ()re., in bags realy for shipment. Whe:at is exported in bulk (loose) from Atlantic, and in bags from Pacifie, port:s. thus kept down and moisture is held in the soil.

As oats are likely to shell, they are generally cut before they are ripe and while the straw is green. Barley that is to be used in making beer must be fully ripe before it is cut. Wheat is generally allowed to ripen before cutting. The quality is better, however, if it is cut a little before it is ripe, when the thumb nail will indent but not crush the kernel.

There is always a markot for wheat and it brings a good price. Oats and barley mature earlier than wheat and erive back to the farmer the money invested in a shorter time. 
106. Field Peas.-Many farmers are findling it to their advantage to raise crops of field peas. The production is large and the erop a most valuable one. It is fed either as a green crop or cured. As the peas need a support they are generally sown with some other crop, as oats. Peas do best upon a heavy moist loam and grow best in cool climates. They are planted in drills or broadeast and should be covered deeply, with a disk harrow. Several days later the oats are sown and covered with a fine-toothed drag, after which the ground may be rolled.

107. Potatoes. - The United States produces annually two hundred million bushels of potatoes. The yield may possibly be doubled before long, because of the increasing use of denatured alcohol, in the manufacture of which potatoes, as well as corn, are largely used.

Potatoes are raised from seed pieces or euttings, that is, sections of a potato containing one or more eyes. The eyes are really buds, for the potato tuber, as it is called, is really an cnlarged and specially developed stem, and not a real root.

The soil for potatoes should he rich and deep and the seed piecess should be planted deep. Above the seed there must be room for the growth of the new lotatoes. Cultivation of the soil should be kept up until just before the plants cover the ground.

Potatoes are subject to seab (S'ee. 72). This discase may be prevented by soaking in formalin mixtures the potatoes to be used as sered. Often the plants must he sprayed to prevent blight. Experiments on farms in Viseonsin in 1905 showed that the average cost of spray- 


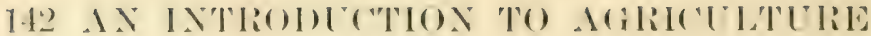

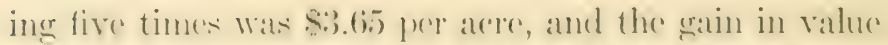

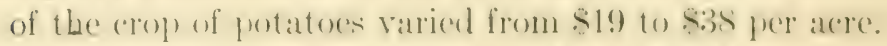
These experiments were tried on six- to tentare areas.

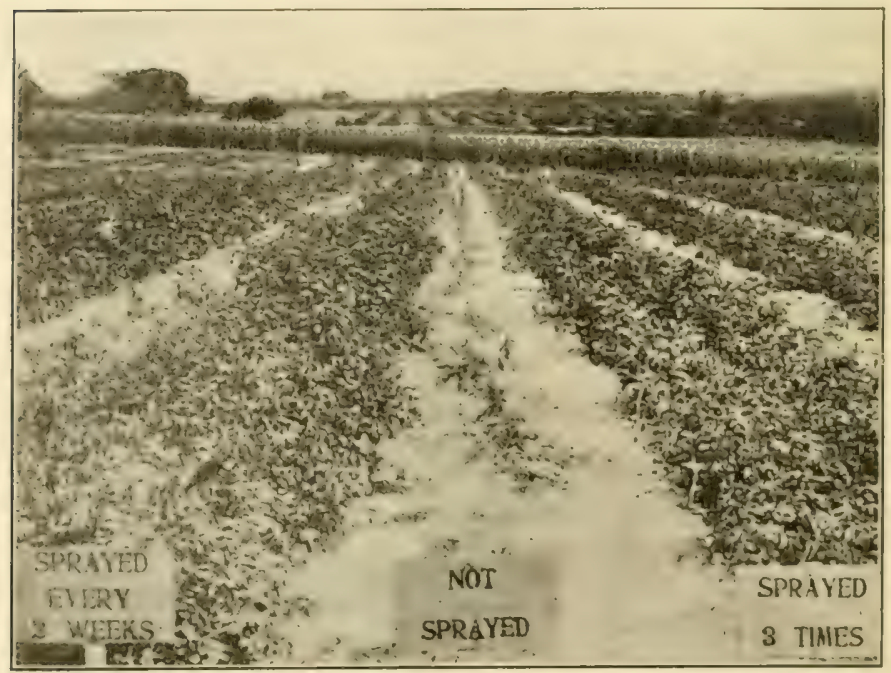

POTATO Sirayta Experimexts.

The gain due to spraying was 233 bushels per acre.

From Ifarwood's "The New Earth," by courtesy" of The Macmillan Company.

The sprayed plots were each one aere and the "eheck" plots, not sprayed, were one half acre. This made the experiment extensive enough to be convincing.

Raise potatoes and spray some with Bordeanx mixture and leave some unsprayed. Notiese the differenes in results.

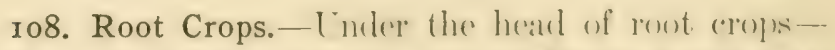
that is, ldants whese roots are used for food-we maty mention beets, sugar beets, carrots, and turnips. Much 
attention is now being given to raising sugar beets. In the neighborhood of a beet-sugar factory they are especially profitable, because they are raised on contract, and the farmer knows beforehand the price at which he is to sell his erop. For this erop the ground should be plowed and manured in the fall, and then plowed again and harrowed in the spring. The soil must be deep, so that the plants will not be pushed up out of the ground as the roots grow, for the part above ground is waste. Commercial fertilizers containing much potash are often used. They should be put on in the fall so that they may be washed into the lower part of the soil. The seed is sown by machine in rows eighteen inches apart. When the plants are up so that they show in the row, they are thimned with a hoe. A few days later they are thimned by hand so that the plants will be ten inches apart.

Carrots are grown largely for feeding to stock, although young carrots are much used for human food, especially in cities. They recuuire an execedingly mellow soil, sandy preferred, and must be kept free from weeds. They should be planted rather early for the early crop and as late as the midllle of June for a late crop, after the weeds have been killed by harrowing (Nee. 25).

Turnips are often sown broadcast as a "eatch" ('rop) - nne sown between the periods of other crops-after early peas or potatoes. They are used somewhat as a table food, but mostly for stock.

ro9. Cotton.-Cotton is of so much importance in the Southern States that it has won the name King cotton. Althomgh a tropical plant, it thrives in the temperate 
zome. For its best production it should have a "climate with six monthe' frextom from frost, a moderate werlldistributed rainfall during the plant se growing season, and almulant sunshine and little rain during its maturing period." The value of the eotton plant resides in the long fiber attached to the seeds.

There are two varieties of the plant important in the Inited states-the short-stapled upland rariety, com-

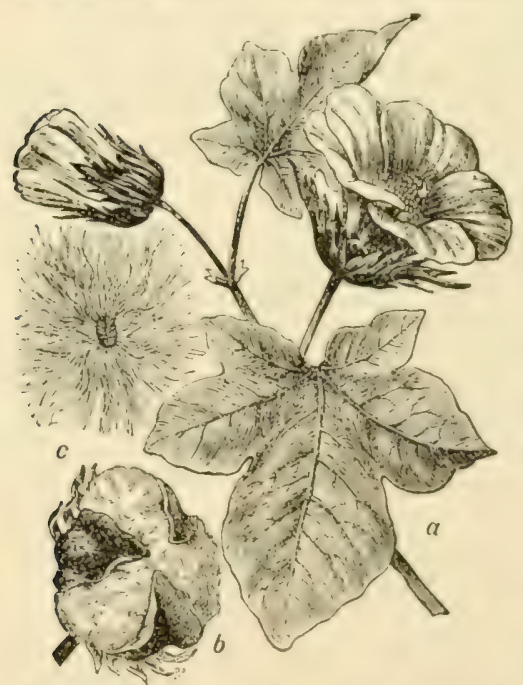

('otron PLaNT. a, flowring branch: b, fruit (boll) hursting: c, seed with filuers (lint). After Hissillo. monly grown in the Southern States, and the long-stapled variety called Sea-Island cotton, grown on islands off the coast and in some parts of Georgia, South Carolina, and Florida. The long-stapled variety commands the better price. Some progress has been made by seed selection, cultivation, and hybridizing in improving the cuality of the short-stapled variety. The cotton plant recuires a rich loam soil well cultivated and deepe, as the plant has a long tap root. As it makes very heary drains on the soil, wherever it is raised there should he kept enough stork to consume the seeds and return the fertilizer to the lanel. Peas, beatus, chover, 


\section{FARN CROPS}

and peanuts may be raised as a further benefit to the land as well as for additional fodder.

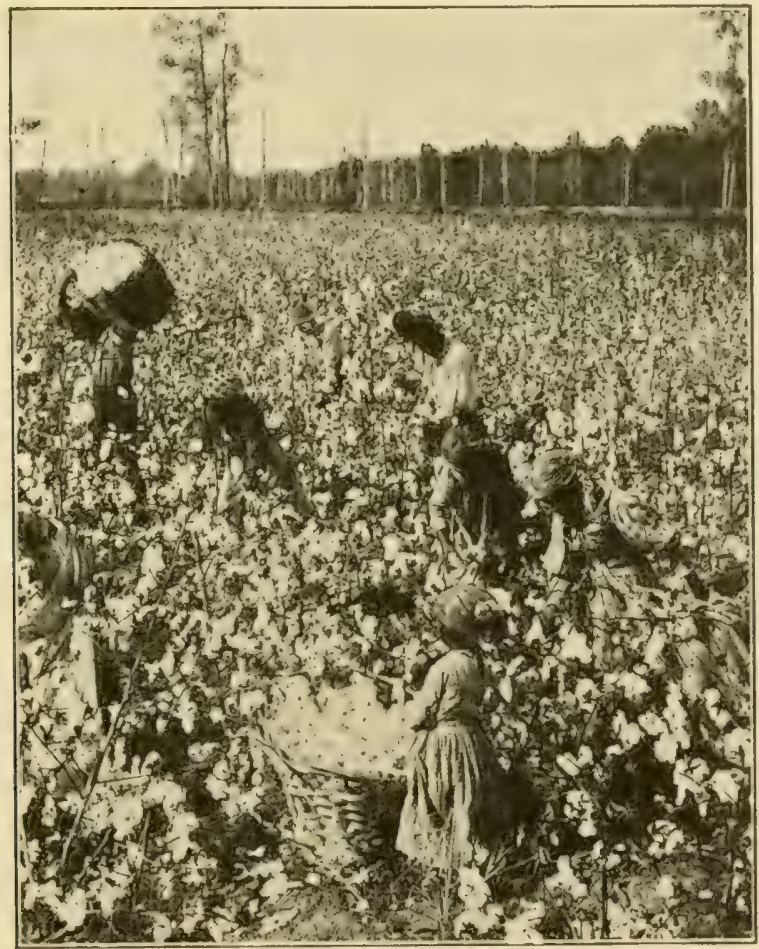

Cingriobt hy Underweol \& Underwoul, N. Y.

Cotton Field.

I ro. Sugar Cane. - Sugar cane was originally a wild plant that had two to four pere cent of sugar, but it has been improved until now there is as high as sixteen per cent. In Louisiana the average amount of sugar in the plant is about eleven per cent. 
Ningar cane is raised from enttings of the old stalks. Trenches are plowed and the stalks are covered. The land must be tilled and keret free from worels. The land is planted erery second or third year in the Inited states, but in tropical countries plants will spring up from the stubble for ten years.

I I . Rice.-Riec is one of the most important forols of the human race. Although soreral states are aclapterl to its eulture, we import more into the Lniterl states than we raise. There are many varieties of rice, lut for practical purposes we may eonsider two kinds, upland and Iowland. Cpland rice is treated about the same as the other small grains, but lowland rice is raised only on land that can be flooded. Most of the rice grown in Americas is produced on the rich lowlands alonerstreams, marshes, or level lands capable of irrigation. Not enough attention is given to the raising of rice in this combry.

II2. Tobacco.--In some parts of the Lnited States the raising of toluaceo is an important industry. The United States raises more than twiee as much tobaceo as any other eountry in the world. There are several important varieties, which vary considerably in their cultural requirements.

Tobaceo plants require a lisht, rich soil for their growth. In the preparation of the soil it is eustomary to plow the land in the autumn to secure the benefit of winter weathering. In the spring the fertilizers are adderl and the land is again plowed, harrowed, and laid out in ridges about three to four feet aprart. The secel is sown early in a specially prepared bed, which is usually in a sheltered place where the young plants can be pro- 
tected. Sometimes the entire bed is covered with glass or cheesecloth. When the young plants are three or four inches high they are transplanted to the ridges in the field, and set twelve to twentyfour inches apart on the ridges, depending on the variety. This was formerly done entirely by hand, but now transplanting machines are generally used. A machine drawn by horses makes the hole in the ground and sets the plant, which is put in

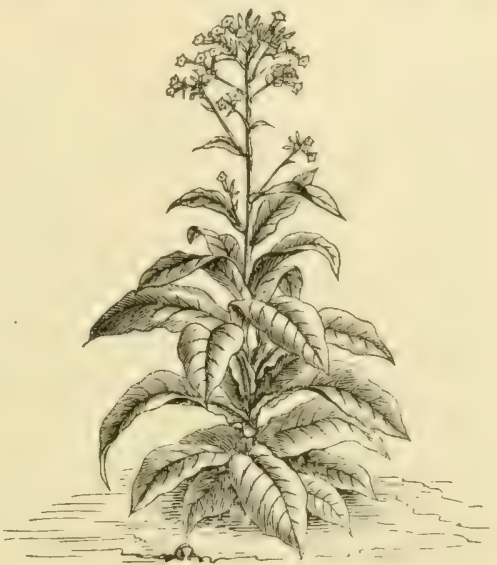

'Tomacco Prant. position by a man on the machine, and then presses the earth around the roots. By the use of such a machine two men can plant three to six acres per day.

During the growth of the plants the soil is constantly kept in good tilth by the use of cultivators and hoes. When the flower buds appear the stem is broken off about three feet from the ground, to kicep all the strength of the plants for the growth of the leaves. This process is called "topping." Following this the young shoots, ealled suckers, which grow in the axils of the leares, are also broken off.

As the leaves ripen there are two methods of harvesting. In the one case they are broken from the pliant and hung in a shed to cure. In the other method the entire 


\section{S AN INTROTUTO"TION TO AGRTCTLTURE}

plant is ent down and hume in a shed when some of the leaves are just ripe and others are still green. By this method the leaves do not all eure alike, as ther do when

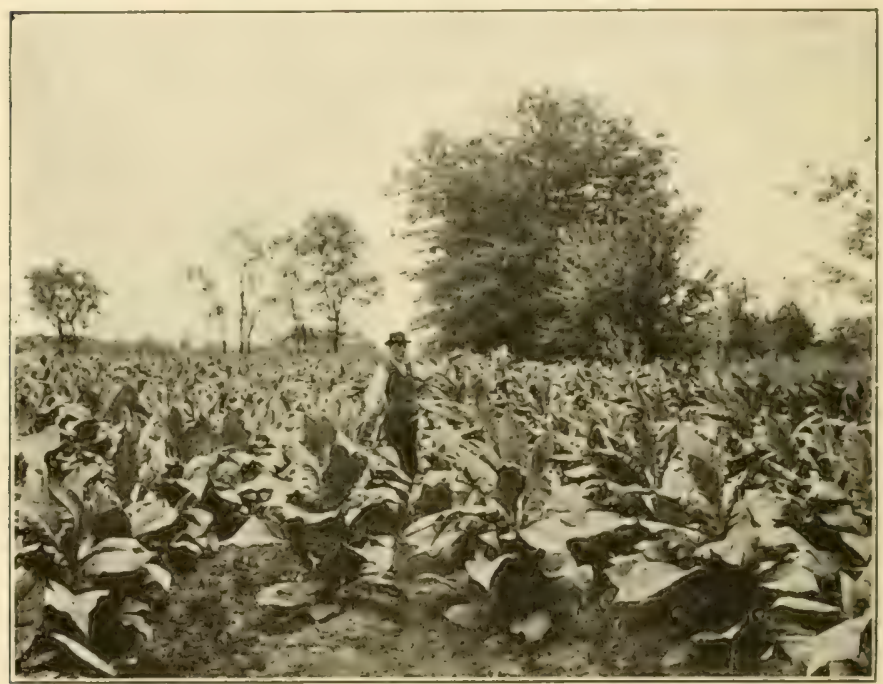

Tonseco FIH:LA.

all are allowed to ripen on the plant hefore they are gathered, but it involves less work and is in rather general use.

The separate leaves, or the stalk and leaves, which were humg in the sheds are allowed to dry and at the same time underego a change called "emringe." The value of the leaf depends to a considerable extent on the satisfactory eompletion of this "curing." The sheds are comstructed so as to regulate the supply of air currents. moisture, and heat. When the leaves are ened they are taken down and if still on the stalks, arestripped off and 
placed in bundles to undergo a further change known as "fermentation." The aroma from the cigar depends to a large extent on this "fermentation."

The tobaceo is now ready to be manufactured into cigars, or smoking or chewing tobaceo. Most farmers sell their tobaceo after it has been cured in the sheds and before the process of fermentation has been accomplished. The latter process is then completed by the tobaceo buyers, who have special facilities for regulating the process which the farmer does not possess.

\section{SUMMARY}

Forage crops, such as grasses, clovers, and alfalfa, are important farm crops as they are the principal feed for stock.

Corn is a very valuable crop both for human and for animal food.

Wheat is a slow maturing crop, while oats and especially barley return the money invested in a short time.

Tobaceo needs an especially rich soil and requires great care in its raising and curing.

Wost farm crops, except hay and small grain crops, require cultivation, which keeps the soil in good condition and free from weeds.

\section{QUESTIONS AND PROBLEMS}

r. Is it good farming to pick the ears of corn and leave the stalks to be plowed in? Why?

2. Would you burn the straw stack af ter the grain is threshed? Why?

3. What would you do with the straw?

4. It cost \$113 to spray 30 acres of potatoes five times. The average yield of sprayed potatoes was 240 bushels to the acre. The average yield of unsprayed acres was 150 bushels. At 40 cents per bushel, what was the gain for the thirty acres? 


\section{CHAPTER XIV}

\section{THF ORCHARD}

Ir3. Apples.-( )ne of the most important erops that the farmer ean raise is apples. Hardly any othere fruit is so widely enjored or so useful. An apple has two thirds as mueh nutriment as a potato of the same wright. For eating out of hand it is always in demand. Whon cooked in the form of sauce, pies, dumplings, baked or any other form, it is of superior exeellenes. The juice, when sweet, furnishes a fine beverage, and when sour and fermented, produces a vinegar that has no rivil. By a proper selection of varieties, a supply of apples may be had the year round.

The apple tree is started from the seed. As it will not come "true" (see. 94), at the end of the first or serond season a scion of the desired variety is grafted on the seedling roots (fiee. 9.4). For this purpose the seerlling is taken up, and the scions and seedling should be kept in a collar in moist sand. In the spring it is planted again, and after one or two seasons of growth it is ready for the market.

A clay loam soil (see. \$) seems best adapted to raising apple trees. Cenerally, the land should have an castern or northeastern slope, to lessen the danger from 
sun seald in long summers. The soil should be in good condition, well tilled, and with a natural drainage, because apple trees will not endure a water-logged soil. The trees should be set twenty-five to forty feet apart each way.

In general, the land between the trees should not have erops grown on it, although this will vary with the particular circumstances sometimes. Clover may be grown and left on the ground as a mulch. This will

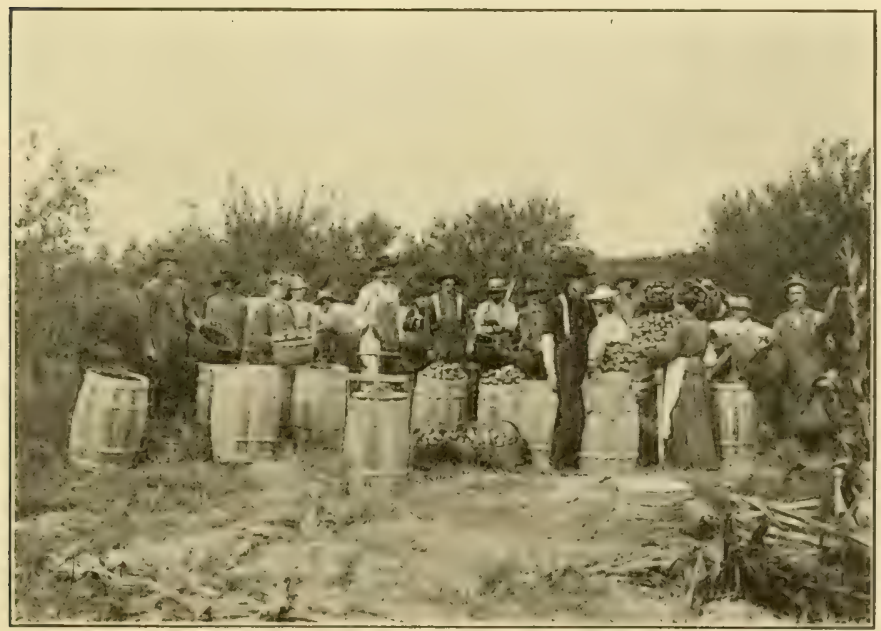

PICKING AND PACKING APPLES.

provide nitrogen (Nece 41) and protect the ground from the heat of summer and the cold of winter. If necessary, fertilizers should be used, eonsisting of banyard mamure or wood ashess. Four hundred to six hundred pounds to the acre of wood ashes is a suitable applieation. 


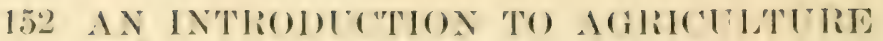

Anyone intending to raise apples should first find out from his neighbors what varieties have proved suecesful in his locality. It is not well to invest too hoavily in untried varieties. The safest varieties, where they will grow, are the standards, such as the Baldwin, Cireening, Winesap, Oldenbure, Red Astrachan, and Northern Spy.

Apple trees should be pruned to produce large fruit and to facilitate pieking, among other things:. The trees must ife sprayed at the proper time to prevent the ravages of insects and discases. It is a waste of time and money to raise inferior apples.

The picking must be elone by hand, and eare must be taken not to loosen the stem from the applle. The apples should be carefully packed in barrels or crates, and should be slightly shaken together and compacted, to keep them from rattling around and bruising aach other.

I14. Pears.-Pears are a much esteemed fruit, and great quantities are sold in the markets for immediate consumption and for preserving.

Pears are propagated by budding or grafting (Chappter XI) upon the secedlings. A grood soil is recpuired. The trees may be set closere than apple trees. It is best in setting out a pear orehard to use more than one kind, as the trees may not bear well unless their blossoms are fertilized by pollen from a different variety (Sce. 81). Pear trees do not require so much pruning as apple trees. their halbit being to branch very much less. What was said about care in picking and handling apples applies with even more force to pears. They are of ten wrapped separately in paper and packed in crates only one or two layers deep. 
Pear trees are subject to many ills, among them blight and tree girdlers. The blight is caused by a fungus which causes the ends of the twigs to die. The pear-tree girdler lays her eggs in the twigs and then girdles the twig, with the result that the young have dead wood in which to develop. For both of these, the dead twigs should be removed and burned. In case of blight, the branches should be eut off a foot below the affected part.

I15. Peaches.-The peach is another favorite fruit for eating either raw or cooked. It stands among the first for caming purposes. New Jersey, Michigan, Georgia, and California are great peach-growing states, but in many other states the fruit grows well.

Peaches are propagated by budding, which is done in the fall. The bud should be set on the north side, so that it will not get too much sunlight. As soon as the bud shows life the next spring, the stock is cut off a few inches above it. All other buds should then be rubbed off and not allowed to grow. As soon as the bud has made a good growth, the old part of the tree should be cut off close above it so that the eut may heal over before winter. In the following February the new shoot must be pruned back. Pruning must be done every year in order that the tree may have symmetrical development and the proper number of branches be allowed to grow.

The first year the tree bears it should be allowed to bear not more than three or four peaches, and the next year not more than a peek. A tree properly treated will bear five to ten bushels for twenty years. 


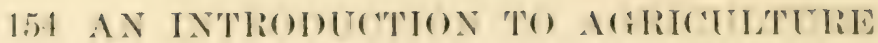

II6. Cherries and Grapes.- ('herries and grapes are raised with as little trouble as any fruits and are always decirable. Cirapes should be sprayed with Bordeatux mixture as the buds break, to prevent rot and mildew. fome persons spray cherries with kerosene emulsion just. as the blossoms fall as a safeguard against the moth that would otherwise lay its exgess in the ovary of the cherry blosisom. Cherries and grapes always find a ready market, and if they are of good varieties and have been carefully picked, they bring a good price.

II7. Marketing Fruit. - I fruit well raised is half sold: but if fruit is raised for the market, as much judgment may be needed in marketing as in raising. 'There will always be more than one grade of fruit, and each grade should be sold for just what it really is. There is generally a demand for second-grade fruit, but not at first-grade prices.

Fall fruits and those which perish easily should be disprosed of as soom as possible. It is better to sell for a small profit than to risk losing the whole. The fruit. raiser should know the eondition of erops in all parts of the enuntry, so that he may be able to judge whether it is best to hold his erop for a higher price. IIe must also decide whether it is better to sell at onee at a small priee than to get a large price later, after part of his fruit has sproiled and he has had the expense of sorting it.

Ir8. Transplanting and Pruning.- In transplanting trees, choose the time when the leares are off and the ground is moist. Dig the tree earefully so as not to ent off many of the small terminal rootlets, or to let the roots get dry by exposiure to the air. In any soil 
How to Plant a Tree

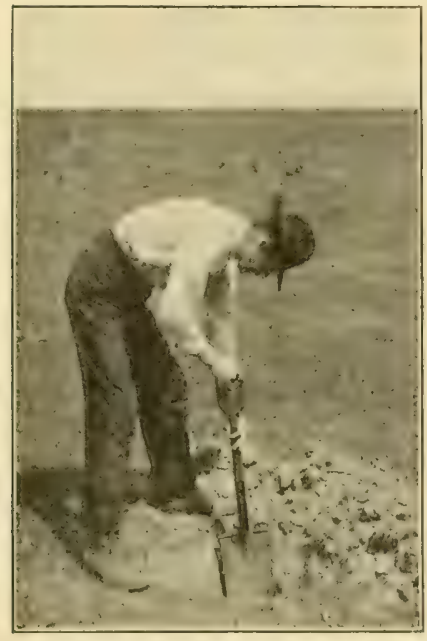

1. Dig the hole twice as large as secms necesiary and fill in the bottom with fine rich soil.

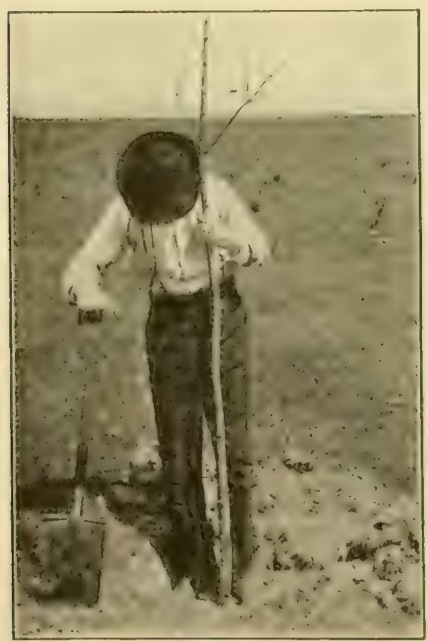

3. After the roots are carefully covered press the earth down as the hole is filled.

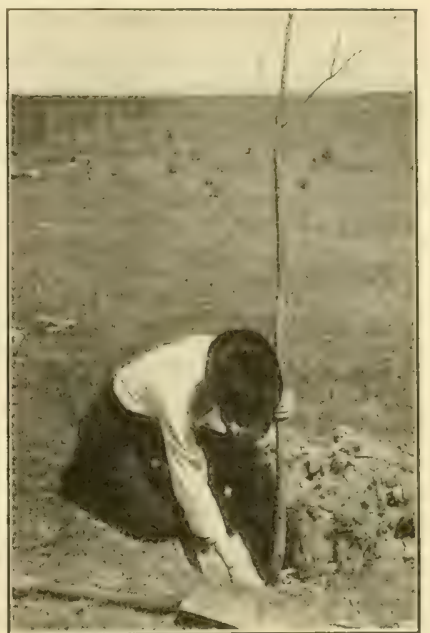

2. Pack the soil firmly about the roots, taking eare to spread them.

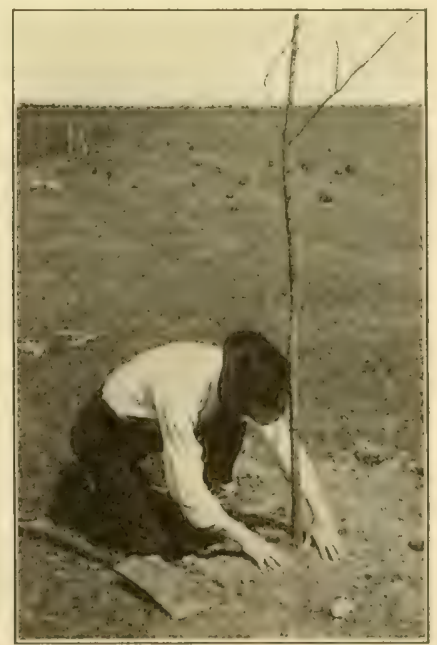

4. After the tree is planted mulch it with loose earth so that the moisture may soak in. 


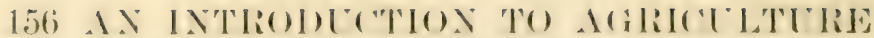

dig the hole twiee ats latrere ats seems neeressary, and fill the bottom with fine rich soil. Patck the soil firmly about the roots, taking rare to spreat them and not to double them back. Be sure that the roots are not oniy set in grood fine soil, but that there is plenty of loose soil for them to grow into. One person should hold the tree and another should get down and with his hands work the soil all about the roots.

After the tree is placed and the soil replaced, mulch it with six inches of leares or loose mamure. Do not have sod anywhere above the roots of a newly set tiee. Drive in two stout stakes and fasten the young tree, being eareful not to compress or injure the bark. Finally, prune back the top as much as the roots were pruned in taking up the tree. Remember that the roots must never become dry while being transplanted. In some localities it may be necessary to keep the tree watered the first season or two, hut in most places this will not be necessary if the surface soil about the trunk is kept stirred.

Pruning is done to change the vigor of the plant, to remove dead wookl, to produce better fruit or flowers, to open the plant to light and air, to kecp the plant within manageable shape and size to facilitate spraying, gathering fruit, and cultivating, or to train to some desired form. When young trees are set it is generally best to proune some hranches to allow for the roots destroyed in transplanting. The size and puality of fruit. are mate betere hy judicious pruning. Exessive pruning calleses overerowth of wood. Cirapes are produced on the season's growth of shoots from the previons season's 
growth, and so it is desirable to start each season with wood only a year old. Blackberries and raspherries grow on the preceding year's canes, so old eanes which have borne onee should be cut out. The growing eanes should be cut off or headed-in when the plants are two to three feet high.

In regard to the time of year for pruning, opinions differ. It is generally agreed, however, that grapevines should be prumed in the fall or winter, and trees before growth begins in the spring-February, Mareh, and early April in the northern latitudes. Dead wool may be removed at any time.

Good authorities differ in regard to dressings for wounds. Professor Bailey, of comell University, concludes as the result of many experiments that there is nothing better than lead paint, but that the nature of the wound and its position on the tree have more influenee on the healing than either the season of the year when the wound is marle or the lind of dressing used. All authorities agree that the wound should be smooth and the heel short, so that the bark may grow over and cover the wound. Careful pruners cut off large branches twice. The first time they saw alout halfway through on the under side and then saw down on the upper side a short, distane farther out. This prevents the limb splitting as it falls off. The shortstub is them sawed off close to the limb or trunk.

Note various trees ats to methouls of pruning-longe stuls and short, and redative healing. - ("hocese t wo treese of a certain fruit side by side. Sipray one, and compare results at harvest.Study pruning methods in the best orehard in your vicinity. 


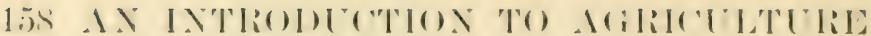

\section{SUMMARY}

The apple is one of the most miversally desimel fruits, amb hy a careful cheriee of variedies a sumply may be hat the year romml. - The proar is rasily raised amel is exerllent for eamning purposes.-The peach is one of the most deliedous of fruits, both for eating fresh and for preserving. It may ixe grewn where the winters are not too severe. - Cherries are always salathle and re-

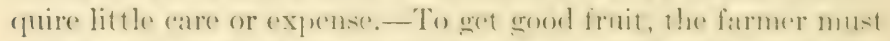

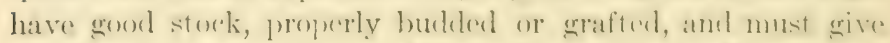
attontion to the condition of the soil, pruning, and protertion from inseet enemies and plant diseases.

I small extrat expense in properly pieking and preparing fruit for the market will often bring larege returns. - The fruit grower must keep informed of the eqeneral endelition of eropss so ats to determine when to sell and what price he can geet.

\section{QUESTIONS AND PROBLEMS}

I. Why is the apple king of fruits?

2. Why is it generally advisable not to raise crope between the rows in an orchard?

3. Would you let hoge into an old apple oreharel? Why"?

4. How many trees may be set in a ome-arere lot, 16 rouls long, if the trees are 2 rods atgate no tree nearep , han 1 rod to the sides of the field, and the emel trees set on the line"?

5. If the eren) is worth s10 jer tree, what would be the value of the yield per acre?

6. I man had 200 barrels of apples that he could have sold

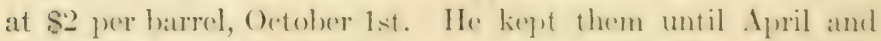
hired a man for s10 to help him sort and repack the two thirds which has not derayed. Then he sold them for 83 pere harrel. If

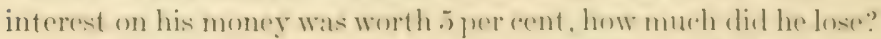

7. How much time, at 52 a dity, will is batreds of apples pay for, at $\$ 3$ a barrel?

8. How many eralpes at 25 cents a hasket will it take to pray for a half hour's rare four times in at sertson, allowing 20 ("ents an hour for labor? 


\section{CHAPTER XV}

\section{CATTLE}

II9. The Usefulness of the Cow.-Perhaps the most important animal kept on the farm is the cow. Among its more important products are milk, butter, cheese, meat, leather, manure. The eow is useful to the farmer chiefly for dairy purposes and for beef. Some breeds of cattle combine, in a measure, the qualities of both dairy and beef types.

120. The Dairy Cow.-The dairy type is characterized by leanness and angularity. It has large abdominal calpacity, deep rhest, a small head, and large ndder. The neck is long, thin, and museular. The back is

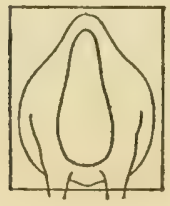

a

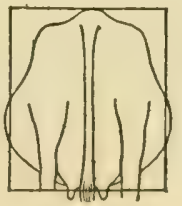

b

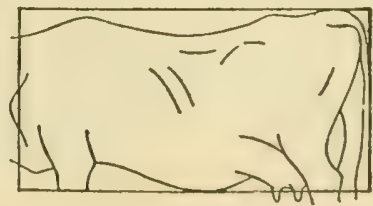

$c$

Diagram Showhe Damry 'Type of Cow.

$a$, front view; $b$, rear view; $c$, side view.

strong, rather long, with prominent hackbone. 'The hips are wide apart and prominent. The milk veins are prominent and branching. Looked at from the side, 
front, and above, it presents the form of a wedere. The four principal dairy breals are the IIolstoin-Firian, Guernsey, Jersey, and Ayrshire.

The Holstein, while a good milker, is used also for beef. It is the laresest of the dairy breeds, althourro the

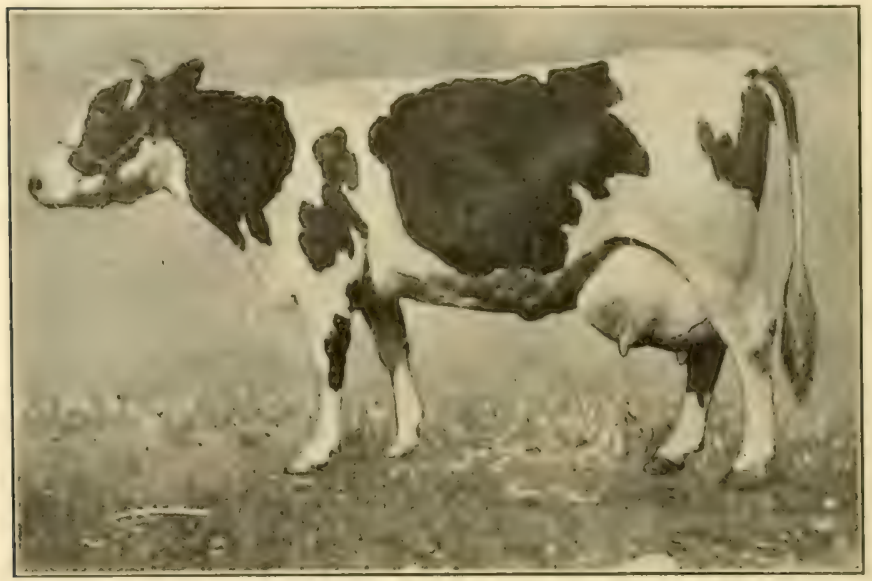

Horstein, Colantha Fourtio's "Jomann.," Champion Dairy Cow of THE WORLD. Record for one yeat: milk, $27,432.5$ lbs.; average test, $3.64 \%$; butter fat, 998.26 lbs. Owned by W. J. Gillett, Wisconsin.

size varies somewhat according to the feed and eare the animal receives before reaching maturity. The colors are black and white. It has been bred in the Netherlands for two thousand years. There it is kept in winter in the common shelter, separated from the family by a thin partition only. The abmelanee of milk, and the largesize of the animal, are attributed to the great care exereised by its breelers for so many crencrations and the rich pastures which it always enjoyel. The cows 
give a large cuantity of milk, but the pereentage of butter fat may be small. In spite of this, however, the Holstein has now (Jamuary, 1910) the champion dairy cow of the world, Colantha Fourth's "Johamma" having produced in one year $27,432.5$ pounds of milk areraging $3.6+$ per cent fat, and 998.26 pounds of butter fat.

The Guernsey is a rather large animal of a quiet disposition, though generally not so large as the Holstein. The eolor is generally light brown, with white patehes on the body and legs. The ears are yellow on the insicle.

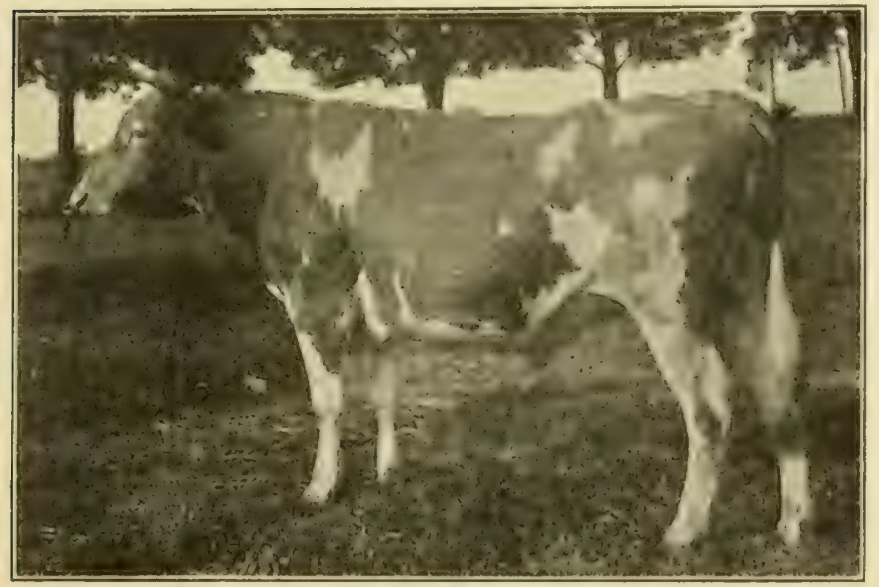

Guernsey Bull, "Casterilues," No. 10980.

Owred by Ralph Tratt, Whitewater, Wisconsin.

The average weight for mature cows is 1,0)00 pounds, and for bulls about 1,500 pounds. The milk of the Guernsey often tests five per eent or more of butter fat. The milk, cream, and but ter from this breed are generally a deeper yellow than that of the other breeds. The 


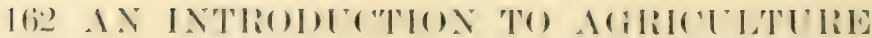

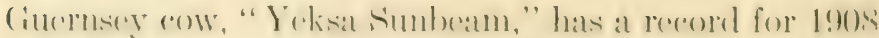

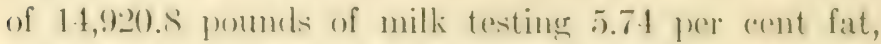
and sit.15 pomels of fat. "Molly i)imple," :3! yours

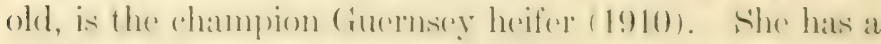

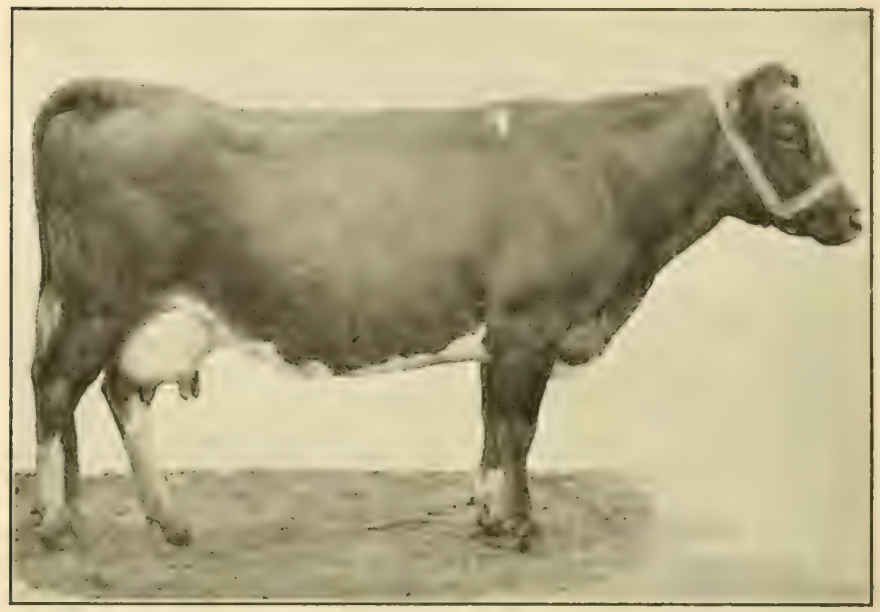

"Yeksa Sunbeam," Guenserey Cow. Record for one year: milk, $14,920.8$ lbs.; average test, $5.74 \%$; fat, $857.15 \mathrm{lbs}$. Owned by Rietbrook Estate, Wisconsin.

record of 906.s9 pounds of hutter fat. The Guernsey has the record for producing more pounds of hutter fat in proportion to cost of keeping than any other hreed.

The Jersey originated on the island of Jersey, near the coast of France. It is a romarkably high-hrod, fincgrained animal. The color may he any shate of lorown to black, various shades of yollow fawm, and tan, or (') white. Fawn and tam seem to be the fatrorite coloss in the United states. Aromel the muzzle there is a rharacteristic ring of lierht-colored hair which grives the ani- 
mal the appearance of having dipped her nose in meal. Mature cows should weigh 800 to 1,000 pounds and bulls 1,200 to 1,500 pounds. The milk of the Jersey is often too rich to feed undiluted to calves. The champion Jersey cow of the world (1910) is "Jacoba Irene," with a record of 924 pounds of butter fat in a year.

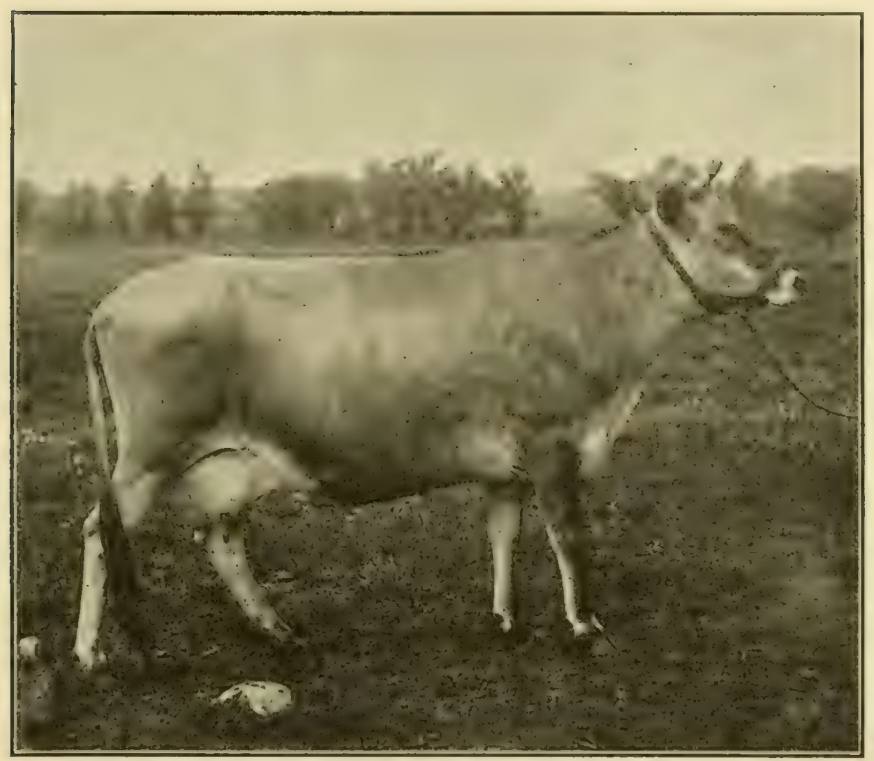

Jersey Cow, "I Jady Pandora," No. 173727.

Owned by F. H. Scribner \& Sons, Rosendale, Wisconsin.

The Ayrshire is a native of Seotland, where it is very hardy, being aceustomed to roam long distances for its feed. It is sprightly and active and well adapted for hilly pastures and hard conditions. The color is usually red and white, the two colors not being mixed, but ex- 
isting in patehes. The standard weight for mature cows is 1,000 pounds, while bulls should weigh 1,500 pounds or more. The breed is noted for the large quantity of milk yielded in proportion to the size of the animal and to the quantity of food consumed. The milk is said to be more easily digested than that of some other breeds.

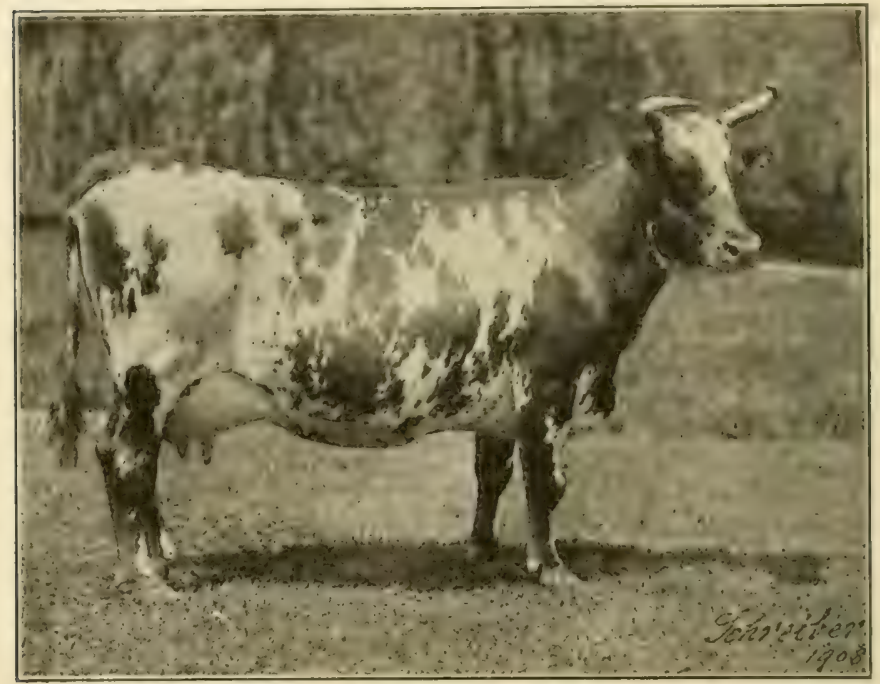

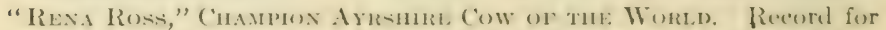
one year: milk, $15,072 \mathrm{lhs}$; average test, 4.26 ; ; fat, $643.2 \mathrm{lb}$ s. Owned by John Valentine, Pennsylvania.

The champion Ayrshire eow at the present time is "Rena Ross," with a reeord of $15,(072$ pounds of milk teating 4.26 per cent, and 643.2 pounds of butter fat.

r2 I. Beef Breeds. - Among the most eommon special beef breeds in Ameriea are the IIereford, Calloway, Aberdeen-Angus, Shorthorn, Polled I)urham, l'olled 
Hereford, and Sussex. The general form of the beef animal is broad, straight, deep, and compact. Viewed
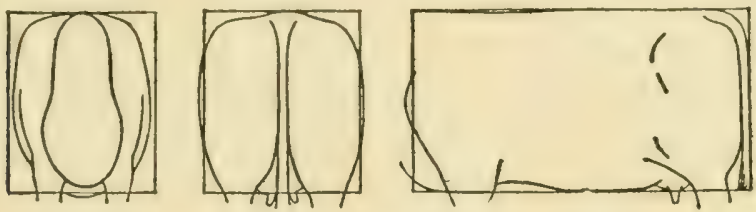

Diagram Showing Beff Type of Cow.

from almost any point the borly should show a rectangular or parallelogram shape. The legs are short, the loins, back, and chest thickly covered with flesh. The

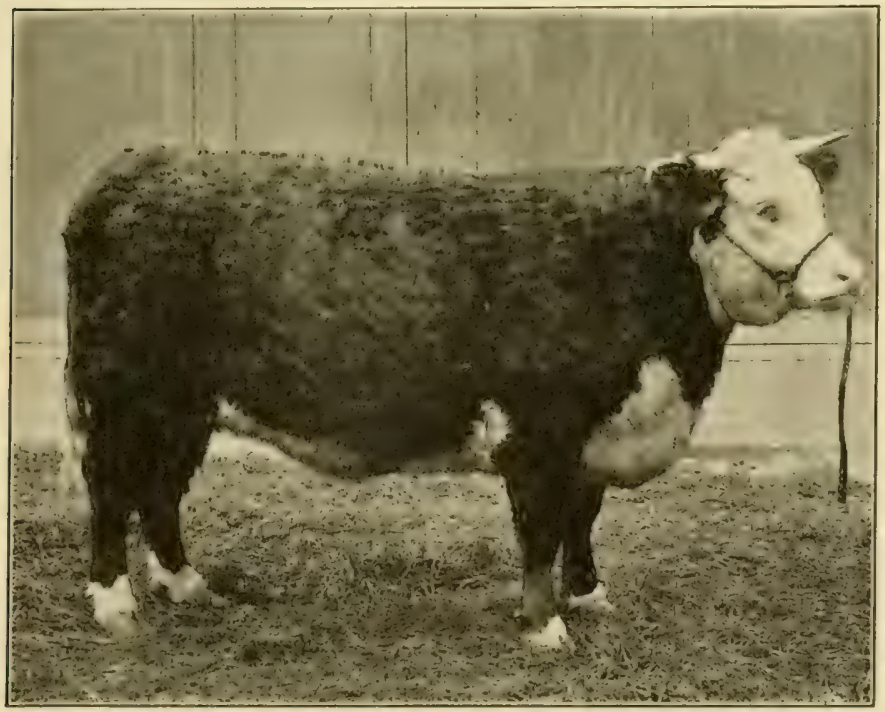

HFTEFORD Cow.

hips are smooth and wide apart. The angularity, characteristic of the dairy type, does not appear. 


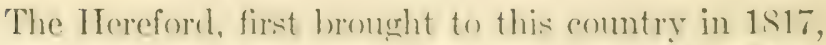
has been imported in ereat mumbers since 1579. This bresel is red, with a whito fares amel a whito line exteneline hack from the hearl to a erroator or less distaner. The (ialloway, first importorl in 1s.r, is used on the 11 estorn ranches hecamse of its hamliness. The hair is lome, fine, shacrer, thick, and hack, sometimes tinged with hrown, and the animals are without horms. In the Vieldle $1 V^{\circ}$ est the Aberdeen-Angus is liept in greater mumbers than the Galloway. It is a larger animal than the lattor; the hare is smooth and black, and it is homless. It was first imported in 1sis. The shorthorn is the most mumeroms beef hreed in America. It has heen hred for hoth heof and milk, so that we fund distind meat and dairy types. When the time of usefulnesis for milk is gone, it is asy to make good heef cattle of them. In color, the shorthorn is red and white, or any mixture of these. Lnlike the striet dairy eow, the food of the shorthorm eroes rather to flesh than to milk. This breel was first inported in 1783.

The Polled I)urham resembles the Shorthorm, exerent that the former has mo horns. This hreed has the distinction of heong the only hereel of cattle originated in the Inited sitates. The l'olled IIereforel is merely a homless typer of the Hereforel. The sussex, imported from the coming of that name in Fugland, has never attained great popularity in America.

122. Advantages in Raising Cattle. - Iou c:an cisily think of many advantages in raising cattle. I tom of hay or errain is worth more mate into leoef or mille or butter than it is in its raw omulition. Cattle furnish an 
income all the year. In no other way (an the fertility of the land be maintained so surely and easily as by the use of barnyard manure (Sec. 35). The animal furnishes a variety of profitable farm products. The keeping of livestock greatly affects the whole plan of farm management.

r23. The Importance of Good Cattle. - I good animal is one that produces the most value from a given amount of food consumed. Iany farmers do not realize the importance of this. A little figuring will show that a good cow will soon pay for the difference between her cost and that of a poor individual. Since it eosts little more to keep a cow that will furnish a pound of butter a day than one that furnishes one fourth that amount, it is best for the farmer to consider how he maty have good cattle.

If the student lives on a farm, he should find the amount of foed consumerl, the amount of milk given, and the pereentage of butter fat for each cow kept on his farm.

r24. How to Improve the Herd.-The farmer who wishes to make as much as possible from his cattle will constantly improve his herd. Unless he is making a business of selling pure-bred cattle it is not neeressary that he have pure-bred animals. He may lieep up his herd by buying good cattle and taking care of them, feeding them properly, and seeing that their surromelings are healthful (see Chapter XX). Or he may improve the herd by breeding from pure-blood or highgrade males. By selling off the lower grate and lieeping only the best the quality can be raised. Even with 
eattle of the same gratle there maty be individual differeners and those that exeed in the points desired should be retained and others raised from them. Many of our best herds are thus produced by "errading up." starting with a pure-bred male, the third generation will be seven eighths pure and the fifth generation nearly as good as pure.

x. After studying this chapter, the student should take oceasion to observe different breests of cat te and note their differences. Sperial risits should be mate to farms where other breeds are kept.

2. The amount of feed and product of each eow of the home herd should be determined and the unprofitable cows singled out.

\section{SUMMARY}

Farm eattle are of two types-lairy breeds and beef breeds - clistinet in appearanes and in the purposes for which they are raised. Cattle are neressary on a farm in order to maintain the fertility of the soil, among other things.

The animal eats the product of the soil and turns it into profit, furnishing a variety of valuathe produets.-The poor animal costs as much to kepp as the sujerior one-The farmer should know the producing value of individual cattle, and should use this knowledge to improve his herd by breeding.

\section{QUESTIONS AND PROBLEMS}

r. Arention some charateristirs of the dairy eow.

2. Why should a dairy cow have a large stomach?

3. What are the advant atges of hornless rattle? Deres it pay to dehorn cattle?

4. Why is it better to sell beef than corn?

5. If in a year at cow eats three tons of hay worth $\$ 10$ per 
ton, half a ton of mixed feed worth $\$ 20$ per ton, and $\$ 6$ worth of pasture, what does it cost to feed her?

6. If a poor cow gives 15 pounds of milk daily for 300 days in the year, what is the return at $\$ 1.25$ per humdred pounds?

7. A herd of $\mathbf{1 5}$ (iuernseys gave an average of 6,626 pounds of milk per year. What was the return per cow if each ate the amount stated in the fifth problem?

8. If the milk was used for butter and produced 35i5 pounds per eow, what was it worth at 25 cents a pound for the 15 cows?

9. If each cow produced one calf worth $\$ 5$ and $\$ 10$ worth of manure, how much did the farmer get for his work?

ro. If six pounds of fat will make seven pounds of butter, how much would the butter made from the yearly yield of "Rena Ross" be worth at 25 cents per pound?

Ir. If the feed for the year cost $\$ 60$, what was the return for care and profits?

12. Estimating the weight of milk as a pound to a pint, what would the milk of "Rena Ross" bring at five cents a pound?

13. Calculate the weight of butter, value, and value of the milk for each of the other cows whose pictures are given. 


\section{CHAPTER XVI}

\section{MILK AND ITS PRODUCTS}

I25. The Composition of Milk.-Milk consists of water in which certain solicls are diswolved and others are suspended. About righty-seven pereent of milk is

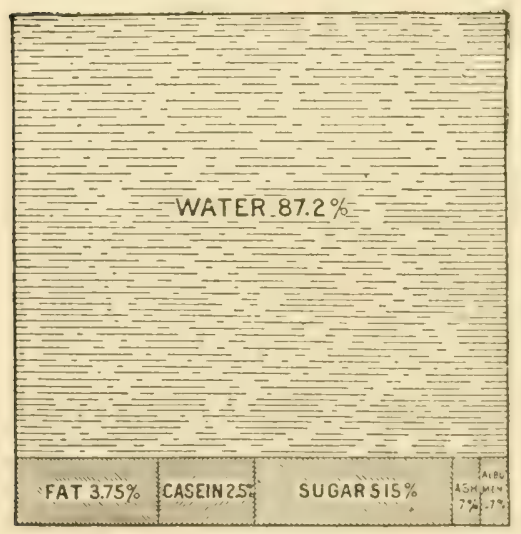

Diagram Showing Composition of Milk.

(S. M. Babcock, Wis. Bul. No. 61.) water. In this water are floating minute globules of fat, comprising about four per cent of the milk. Casein, which is proteid (Sec. 52), forms about two and one half per cent of milk. About five per cent is sugar. A little more than half of one per cent each of albumen and ash, which are mineral salts, makes 11]) the remainder. The average composition of milk is shown hy the ateompanying diatgram.

The fat grobules arorage one tert-thousandth of an inch in diameter, which means that forty of them plated 
side by side would extend a distance equal to the thickness of this paper. In the milk of Jersey and Guernsey cows these globules are larger than in the milk of some other breeds, and so) the cream (which

a. Skimmed milk.

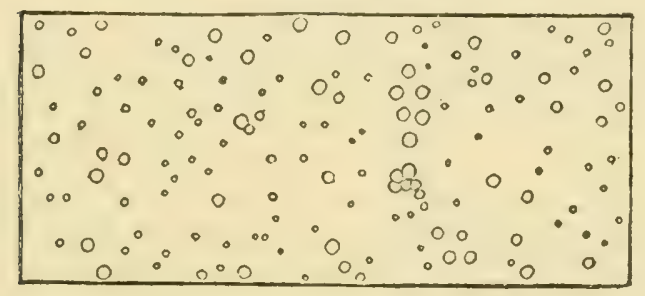

b. Milk.

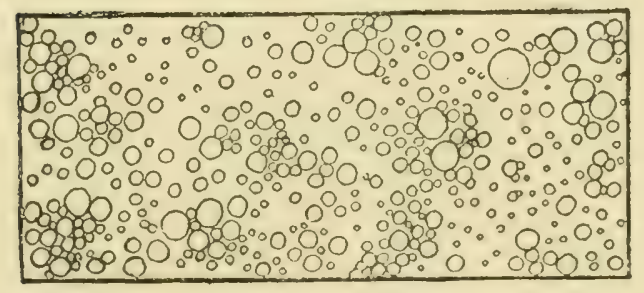

\section{c. Cre:ain.}

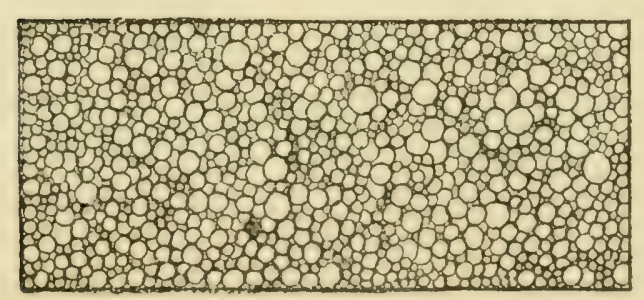

Different Grades of MilK. (Magnified 300 times.)

From Farmurs' Bulletin No, 12, Wisconsin Agrioultural Experiment station, 


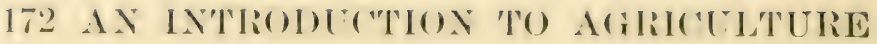

contains the fat) rises more quickly on Jersey or Guernsey milk. The fat globules in the milk of Ayrshires are small.

The sugar of milk may be obtained hy eraporating whey after the other parts of the milk have been remover in the making of rheese. Milk sugarar, or lactose, as it is called, is generally seen in the form of a white powder, which is used by druggists and other's who prepare mediciness. It is not so sweet as ordinary sugar.

Mbumen is the substance that rises as a thin, tough skin when milk is seaklderl. It is often seen on the top of a cup of chocolate or coffee.

The first milk given by a cow for the young calf is called colostrum. It contains five or six times as much protein as does ordinary milk and is not good for ordinary purposes.

Heat some milk and note the allumen on the top.

126. The Food Value of Milk.-Milk is one of the most perfecet foods, as is shown by its we as the entire food of babies and young animals. It contains cascin and albumen to form musele, fat and sugar to produce fat and energy, and mineral salts to produce bones.

127. The Souring of Milk. - The souring of milk is amsed hy hacteria. These minute plant growthe s'ree. 32) may eome from the air or from milk pails and other utensils in the dairy that are not kept absolutely dean. They act on the milk sugar, changing it to "lactie" acid, which results in curdling the milk. Milk is a 
specially good home for bacteria as it contains just the food and moisture they need. When it is at the right temperature, they develop very fast.

To avoid souring the milk, every precaution for cleanliness must be taken. The hands and overalls of the milker
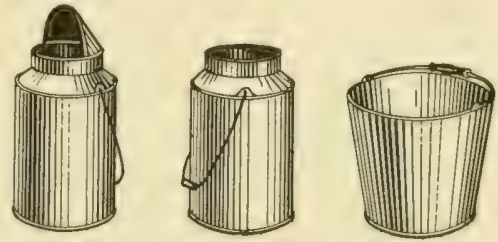

Milk Pails. Note which one is best protected from the dust and dirt. should always be clean at milking-time. Milk pails, cans, and bottles, as soon as emptied, should be washed in scalding water and aired in the sun. If they can

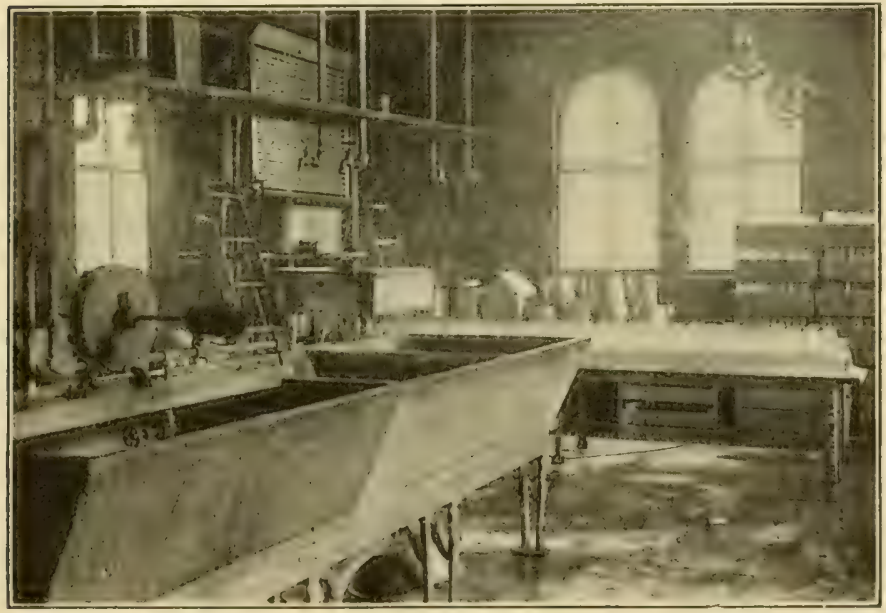

Moder RoOm ann Apparatus for Washing Mirk Bottries.

be sterilized by steam, so much the better. No work that stirs up dust, such as pitching hay, should be 


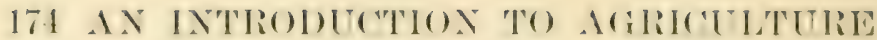

done in the barn just before milling. It is generally advisable to brush off or moisten the cow's sides shortly before milking. If eare is taken always to have everything eoneerned in handling the milk clean, it will keep pure and sweet much longer than if carelessly handled.

Take two samples of mille from the same milline. Allow one sample to cool naturally, athe cool the other by placeing the call containing it in ice water. After a eouple of hours set both samples in a cool place and note which ome sours first.

r28. The Milk Tester.- In order to know the produeing value of a dairy cow, it is well to test her milk in order to see what pereentage of it is cream or butter fat. This can be done by means of a Babeock milk tester. It consists of a machine having a frame mate to whirl rapidly, and suitable for holding tuhes, or bottles, of milk. In a test.hottle is placed $17 \frac{6}{10}$ culbic centiineters of milk from one of the lots of milk to he tested. Before the sample is taken, the milk should be thoroughly mixed. To this milk is adeded an ecutal amount of sulphurie aredel, which dissolves all of the milk eonstituents exerent the fat. The bottle is then put into the tester and whirled at high speed for five minutes. IIot water is added to bring the eontents up to the base of the neck and it is whirled again for two minutes. Here hot water is then added, sufficient to float the fat up into the neek of the bottle, and another whirl of at minute is giren. The pereentage of fat is then clearly shown on the erachaterd neck of the bottle.

129. The Separator. - When a large amomnt of milk is handled, the cream is generally separated from the rest 


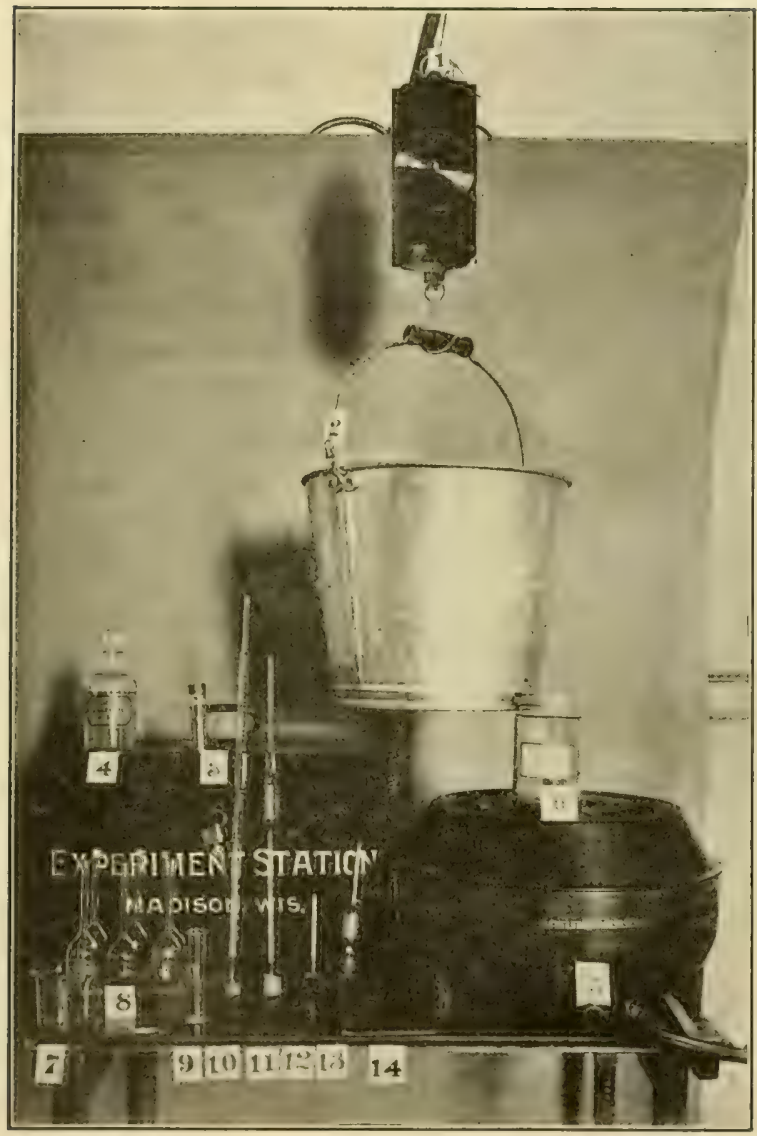

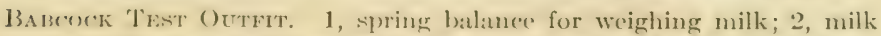
pail; 3, galvanized-iron box for kerping samples of milk; 4 , sulphuric acil; 5, lableock hand tester; 6, composite sample jar; 7 , beaker for arlding acid; 8, I3abrock test buttles; 9, acid measure; 10, 25-ces. pipette; 11, 17.6-e.e. pipette; 12, clinieal thermometer; 13, hydrometer for determining strength of sulphuric acid; 14, note-book. 
of the milk hy means of a machine callerl a seplarator. This matehine maty he rum hy steam or hy hand. A good seplarator, froperly run, will talie ont at last ninctyright pere ant of the cream furesent, while skimming by hatme by the simple eravity prosers oftem loaves twonty or thirty pere cont of the (reame. In the separator the unskimmed milk is made to revolve at an exeredingly high rate of sperel. The milk, heing heavier, is thrown to the outside of the revolving vesisel, while the cream is forecol inwarel. By means of tubes placed at the right points, the milk and the cream are drawn off separately.

r30. Cream. - That part of the milk into which most. of the butter fat finally gathers is called cream. It may contain fifteen to sixty per cent fat. The separation of the fat from the milk is brought about by gravity acting on the standing milk. Cream is lighter than the rest of the milk, and so the latter sinks to the bottom of the pan and the cream is pushed up). We say "the cream rises," but in reality it is pushed up.

Cream is more or less yellow in eolor, the particular shade depending on the breed and individual presuliarities of the eow, and the lind of food eaten. Cireen grasis produces a more yellow cream than does dry hay.

The amount of cream in a given quantity of milk depends on the eow, and is quite independent of the foed. More feed orelimarily produces more milk and thus a larerer amount of (ream, lout not a lareger poreportion as related to the whole amount of milk. One writer has said: "The richness of a cow's milk is as much a chatracteristic of the oow as the color of hor hatr, and foreling has as little to do with it." 
I3r. Skimmed Milk.-The skimmed milk that is left after the cream is removed is still a good food, especially for young animals. The fat is gone, to be sure; but all the other constituents remain and a little meal will furnish an equivalent amount of nourishment. The meal costs only a fraction of what the butter fat is worth, so that it is much more profitable not to use the unskimmed milk as feed for animals. Skimmed milk contains more protein than an equal weight of potato, and nearly one fourth as much carbohydrate (Sec. 56).

I32. Butter.-When cream has been tumbled about for a half hour or more in a churn, the particles of fat

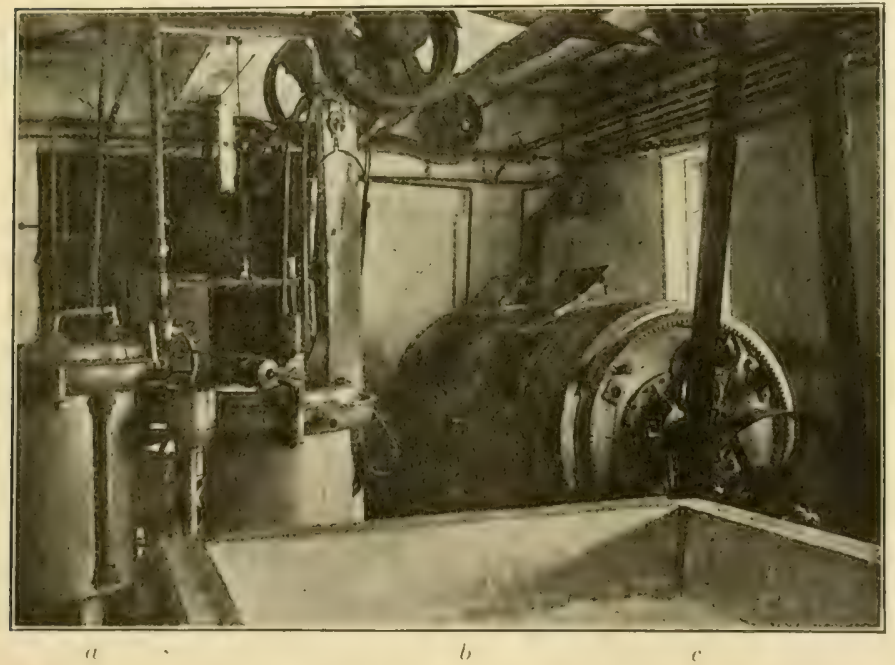

A Mombra ('rfanmix. Siluming a, pastenrizer with a capacity of 2,500 pounds per hour; $b$, vat in which cream is ripened 12 to 20 hours after being pasteurized; c, 1,000-pound churn.

Courtesy of the Union Produce Company, Whitewater. Wis. 


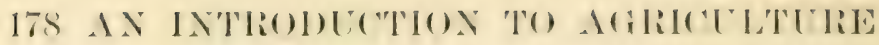

unite more closely into small srains, separate from the water and other parts of the mills, and become what we call butter. This product still contains about one per cent of protein, and may contain more. Butter is generally made from soured cream, one or more days old, because the flavor of such butter is ensistered more desirable by most persons and it has better lieeping qualities. The cream should be kept at a low temperature, $40^{\circ}$ or 50$)^{\circ}$ Fahrenheit, and the churning should be done at a temperature of 5$)^{\circ}$ to $51^{\circ}$ in summer and $51^{\circ}$ to $58^{\circ}$ or higher in winter.

Perhaps the best churns are those of the barrel type, in which the cream simply falls from one sille of the chum to the other. The ardition of paddles is thought to injure the grain of the butter. Most persons demand that their hutter be yellow, so butter is eolored during at least a part of the year. Anmatto is the coloring matter most commonly used. A small quantity is added to the cream before churning. Butler generally contains about eightern per cent. Watter, salt, and curd.

133. Cheese. - The same separation of the easein that is caused by the souring of milk may be produced by adding remet to milk. In cheres-making remet is added to produce this curd. After it is properly formed by the help of heat, it is carefully (aut into small pliceres. II at is apulied for perhaps three hours longer to derelop acislity, before the whey is drawn off. The curd is then handled to make it solid and to drain off surplus water. It is later run through a mill and ent into small pieceses, salted, put in hoops and fresoses to form, and finally 
cured in a cool room for several weeks before it is ready for the market.

Cheese contains casein, albumen, ash, and fat and is very nutritious. Sometimes the cream is skimmed off before the cheese is mate. Such cherse is ealled skimmilk cheese, or skimmed cheese and in some states it must be made at least nine inches high to distinguish it from full-cream cheese. Fat is sometimes added to skim-milk cheese to take the place of the cream. It is then called filled cheese.

(iet a little piece of remnet from the cheese factory. Place it in milk and observe the formation of curd.

The liquid left from cheese making is called whey. As it has lost its easein as well as the fat, it is not nearly so valualule a food for calves as is skimmed milk. For this reason it is often better for the farmer to carry the milk to a butter factory than to a cheese factory. It is better still for the farmer to separate his cream at home, for then it is separated before it becomes cold, he has less weight to haul, and he runs no danger of bringing back from the factory skimmed milk from diseased cows. We have leamed that casein is a proteid that contains nitrogen (Nee. 52), and thus we see why it is better to carry back to the farm skimmed milk rather than whey.

The student should visit butter and eheese factories and see separators and the Babeock tester at work, if possible.

\section{SUMMARY}

Milk is eomposed of water, filts, protein, surar, and salts. It contains the food clements that produce muscle, bone, and 


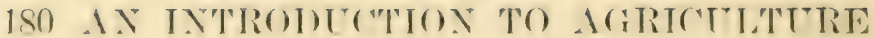

fat.- Cleanliness in rvery devail is neersiary to provent the souriner of milk.-Fat of milk is mate into hutter.-l'roteid of milk forms the bulk of aheres. - The hy-produet of hut ter-maliner is skimmerl milk, whieh is nume valuable as foul than the hyproluet of whesemaline, which is whey- It is usually lintter to sell butter than cheese upon the farm.

\section{QUESTIONS ANI) PROBLEMS}

1. What is protein?

2. How does protein differ from carbohydrates?

3. Why is skimmed milk worth more than whey?

4. Why may it be better for the farmer to sell butter than cheese?

5. Why is it hetter to feed skimmed milk and meal to (allews than to feed unskimmed milk?

6. How would you get the albumen out of milk?

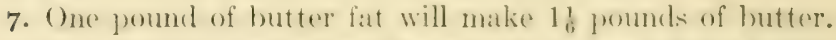
Supposing that the sepuatrator takes ont af prer cent of the butter fat, how many pounds of butter an be made from solo pounds of milk that tests 4 per cent butter fat?

8. If this nilk would bring so eents per hundred pounds at the factory, how much more would the butter bring at 20 cents a pound?

9. How many hours extrat work would the increase paty for?

ro. Which weighs more, at gatlon of cream or at gratlon of milk? Give a reason for your answer.

Is. What is the atrantage of testing the milk of the soprateate cows of a herd? 


\section{CHAPTER XVII}

\section{THE HORSE}

I34. Antecedents and Types.-Geologists have determined that in prehistoric periods there were horses in the Inited states. The horses now used in this country, however, are descended not from these, but from imported stock, chielly from Europe. Arabia aud Fastern countries have also furnished many fine animals that have contributed to the development of the present types.

The types of horses renerally recognized are classified as draft, coach, roadster, speed and saddle horses, and ponies. To these may be adderl a fourth type, ereneral utility horses, or carriage and coach horses; they are heavier than the trotter and lighter than the draft horses. Although these types are very different from one another, it is believed that they have all sprumg from one stock. The differences have grown out of the various conditions in which horses have lived and worked, in many different climates and through many generations. Felection and skillful breeding also have done mudh to chance the characteristics of horses.

r35. Desirable Characteristics.-There are cortain points, well known to horsemen, which should he calle- 
fully oberved in buyine a horse. Loolied at from before or behind, the lews shomld be straight and the feet ats far apart as the wilth of a hoof ; that is, the horse should

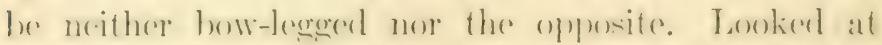
from the side, the front leages shomld be straight to the

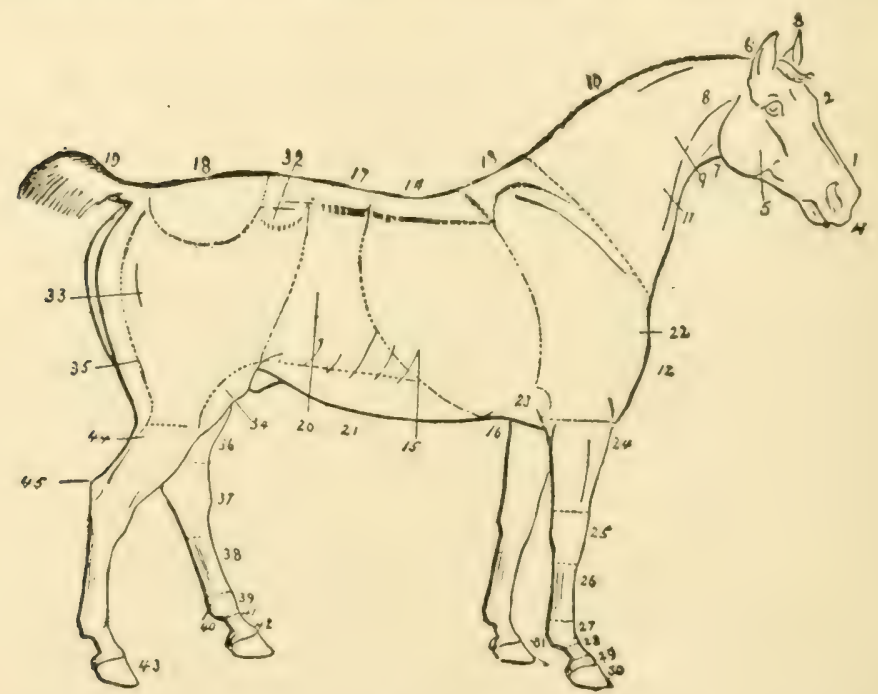

The External Pants of ture Honse. 1, face; 22, forchead; 3, ears; 4 , muzale; 5 , eheek or fowl; 6 , poll; 7 , throat; S, caroticl; 9 , neek; 10 , erest; 11 , jugular channel or furrow; 12 , breast; 13 , withers; 14 , back; 15 , ribs; 16 , girth; 17 , loins; 18 , croup; 19 , doek; 20, flank; 21 , belly; 22 , point of shoulder; 23 , elbow; 24 , forearm; 25 , knee; 26 , canon or shank; 27 , fetlock joint; 29 , pastern; 29, coronet; 30 , foot; 31 , ergot and fetlock; 32 , haunch; 33 , thigh; 34 , stifle; 35 , buttock; 36 , leg; 37, hock; 38, eanon or shank; 39, fetlock joint ; 40, ergot and fetlock; 41 , pastern; 42 , coronet; 43 , foot; 44 , lower thigh; 45 , point of hock.

fetlock, or pastern joint, and the hind lecs should have no temeleney to "cock" ankle in fromt, but be weell set. The forehead should be hroad, nostrils thin and open, 
and the two halves of the lower jaw wide apart. The eye should be full and should have an intelligent, not vicious, appearance. The ears should be creet and active. In a draft horse, the chest should be broad, and in trotters it should be deep.

I36. Speed Horses. - The Arabians, the Thoroughbred, and the families of the Ameriean Trotter are the horses noted chiefly for speed. Prominent among American Trotters are the Hambletonians, Mambrinos, and Morgans. The introduetion of Arabian hories hats produced great improvement in England; yet it is a faret that those imported into the United states have not been able to compete with Ameriean-bred hories. The Arabians, however, are remarkable for their beauty, intelligence, and fine points.

Thoroughbred is the name given to a distinct breed of English horses which have been bred for racing through many generations. These horses contain much Eastern blood and are noted for their speed and endurance. The colors are usually bay, chestnut, or brown, but sometimes black or gray. The Thoroughbred is used in the famous English hunting trips. The best hunting horses are a cross between the Thoroughbred and the Hackney.

The father of nearly all the American families of trotters was "Imported Messenger," brought to this - country in 17ss. This horse is described as having remarkable life, strength, and enduranee. He wass gray in color, had a large, bony head, short neck, and unusually large nostrils. "All ateounts coneur in representing 'Messenger' as being a horse of very superior, though not 


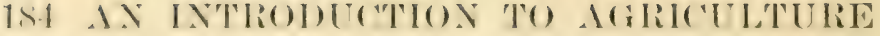

hatmblome, form, and posiessing ext raordinary power and spirit." Hambletonian, one of the most lamons of the Aneriean trottingersese, is descended on the male side

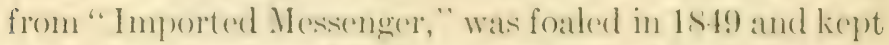
in ()range comnty, N. Y., mut 1s;6. Mambrinos are derecended from ".Iambrino (hieff," foaled in 1st4, a

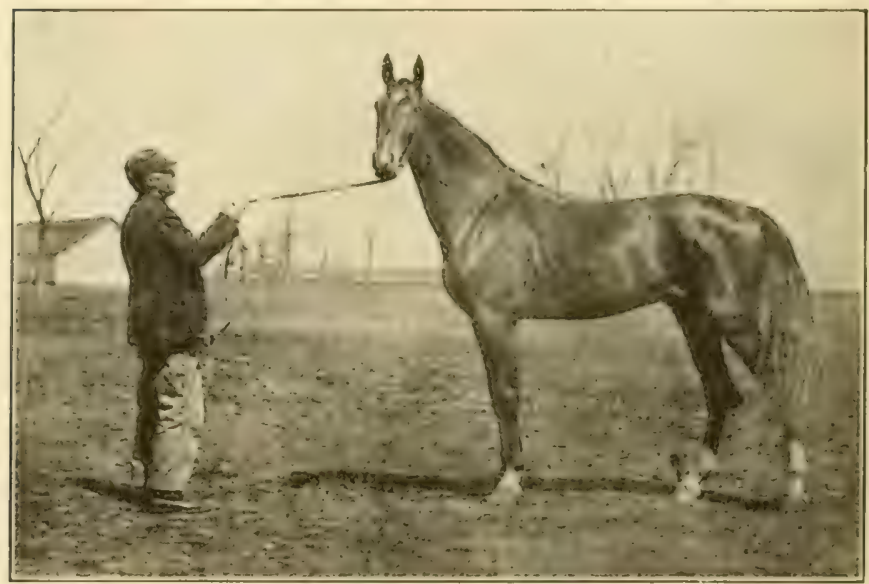

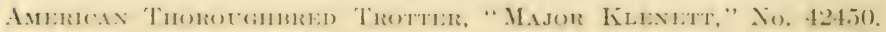
Three yars old; 16 hands high, record, 2.291. Owned by Filenett Brothers, l'ortage, Wis.

great-erandson of "Imported Messenger." "Mambrino Chief" lived in Kienturely and was the aneestor of many" Blue Grass trotters. One of his descemdants, "Minor" IIrir," helds the world's ofticial reererd for 1900s, a mile. faced in 1.59). Another famous parecr, "I)an P'atch," tratees his ancestry back to "Imported Messenger" fortythree times, and has a paeing reeord of a mile in 1.5.5) One of the mont useful of Ameriean trotters was 
"Justin Morgan," the sire of all the Morgans. The Morgans are useful not only as trotters, but for family horses and for general purposes, being noted for speed, enclurance, and reliability. (One of these horses is sald never to have lost a trip in twenty-five year's of serviee on the Boston street-ear lines. This horse, on being retired from active service, was kept by the company in comfort and luxury until he died, at more than forty years of age.

137. Draft Horses. - The draft horses differ from the trotters much as the beef hreeds of cattle differ from the

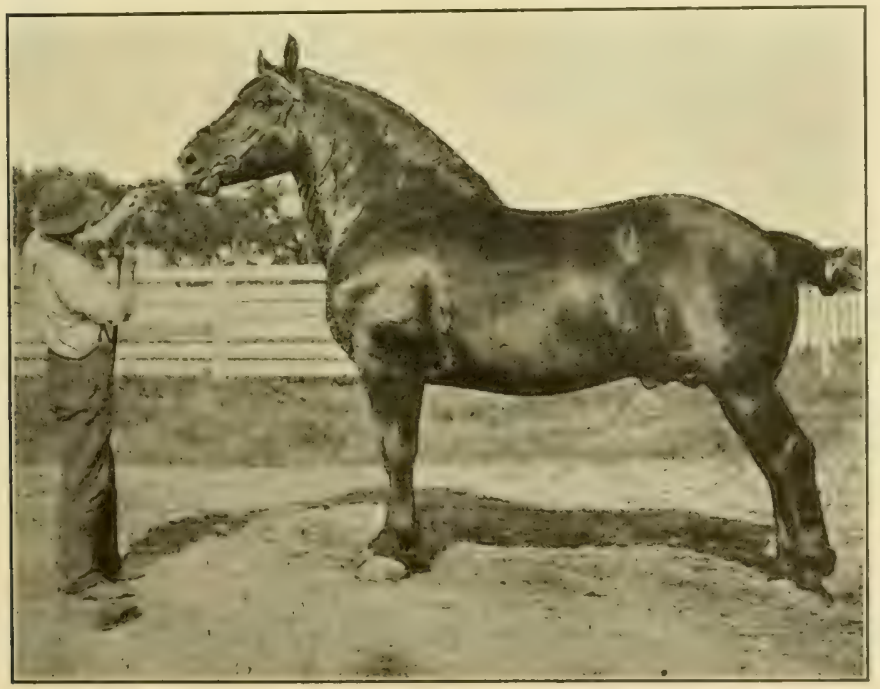

Champion Imported Percheiron, "Stallion Pink." Dunham and Flitcher, Wayne, Ill.

dairy breeds. The body is shorter, broader, and more nearly eylindrieal. The legs are short and stout, the hoofs are large, and the walls are strong. They are 


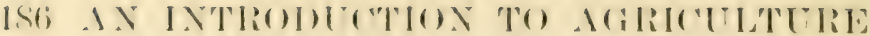

charactrized by errat weicht and rather slow movements.

Among the more important draft hereds are the

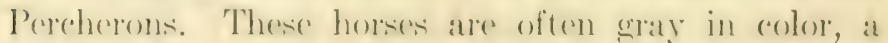

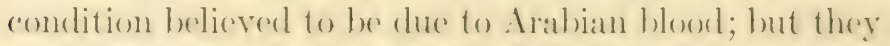

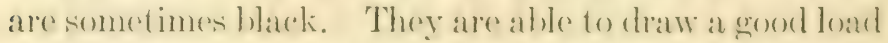
at more than modorate sueed, and although they are heary horses they are by no means lacking in shat).

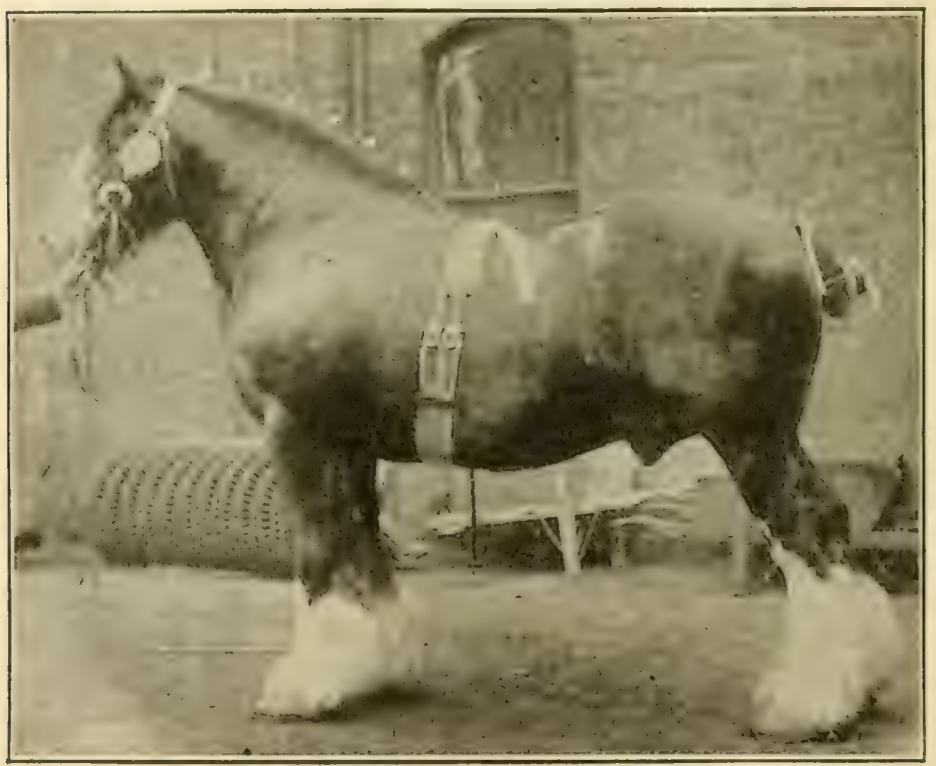

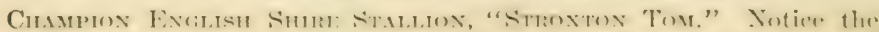

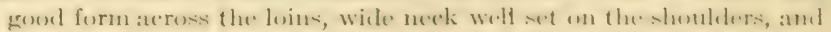
fine forward legs.

The Guglish shime horse is one of the hoaviest breeds. It may les almost any oulur, although hlack, hay, and 
brown are the most eommon colors. It wisully has a white spot on the forehead and may have one or more white feet. These horses ean pull great loals at a slow, steady gait, but lack the life and energy of the Percherons.

The Clyclestale is another draft horse, somewhat smaller than the shire, but much more active. It is a rapid walker and is much prized for that reason. It has a kind, quiet disposition and good courage. In its colors and markings it resembles the Shire.

Other important draft types are the Belgian and the Suffold. Neither is so popular in this country as the above breeds.

I38. Coach Horses.-Coach horses combine the activity of the trotter with somewhat of the strength of draft horses. Many of them are recquired to draw heavy carriages at a good speed. They are also expected to show some style, the more the better. Among these may be mentioned the French coach horse, the German coach, and the Hackney. The Inackneys are said to give endurance to the progeny of the English Thoroughbred, with which they are crossed.

139. Ponies.- Shetland Ponies are the well-known sturdy little beasts that in this eountry are used chicfly for children's pets. They will endure almost any amount of hard usage and poor fare and will do a great amount of work for their little masters and mistreseres. In lingland they are much used in coal mines. Their native home is the shetland Islands, nerth of seotland.

IColsh ponies are growing in popularity in Aneriea, and many are being imported and some bred here. They are also children's pets. 
In the Enited sitates there are two other eommon brexts of ponies, the Bronee and the Sorthern Indian pony, which have desernderl from horses that eseaped from the arly spanish explorers. They are the sadelle horses of the II estern eowhoys and are grood cavalry horses. They have great endurance.

Learn the different breeds of horses in your locality. Somebody knows and will gladly tell you.

I40. Use and Care of Horses. - Nthough horses ap)pear to he stromer and hardy, yot they ate very easily lamer or marle ill. They shomld be forl as recrularly as possible, and should not be overfod, nor should the foed he changed suddenly. The horse has a small stomateh and therefore its fored should not be too bulky. Changing from old hay to now hay or grass is likely to (antse incligrstion, an ill which frecpuently hooomes very serious. Overfereling a horse that has been liept on short rations has the same offect. New oats and corn should be ferd with eaution. Dusty hay is to be aroided, certainly moles sprinkled. When a horse is heated, it should not be forl grain. It is safer and hetter to let the horse stand half an hour. A little hay may he griven, but some careful owners will not grive even hay to a warm horse.

('are should be exorecised also not to give a hoated

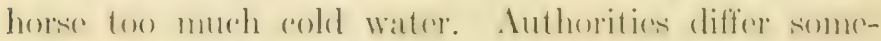

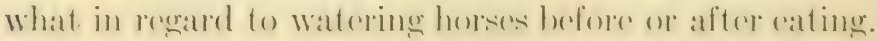

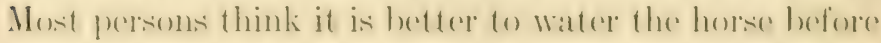
anting: lut if a horse is very hungry he will not drink much until after ating. Many amimals, free to do as they like, (at first, then drink and lie domm to digest. 
their food. There are reasons for believing that Nature is a fairly safe guide in these things.

Hardly any animal better repays the care given to it than the horse. A horse should be groomed each morning, to promote the health of the skin as well as to improve the appearance. In cold weather care should be exercised to prevent a horse getting chilled after being heated. It is bad practice to allow a horse to dry off in winter without a blanket, or to sleep in a wet blanket. It is fair to add, however, that many farm horses are never blanketed and seem to get along just as well, Nature furnishing them with an extra thick coat of hair in such eases. In snowy time the balls should be knocked out of the horse's feet and the snow cleaned out of the hair near the feet when the horse comes in for the night.

In winter, notice the difference in the hair of horses that are blanketed and those that are not.

There are many ways in which a horse may be lamed. Fast driving over hard roads and down hills is likely to cause "knee-sprung" and "cock-ankled" horses. Many persons make the mistake of not having horses shod often enough. A little saving in blacksmith's bills may result in a wreater loss in lame horses. The feect of a horse are seeend to no wher parts of his body in importance.

I4I. The Intelligence of Horses. - Iforses difforerseratly in intelligence, but even the mest intelligent camnot be wholly trusted. A horse will trot along a given roal for years with confidenee; but let a pieece of paper blow 
arems his fath and he may shy or holt or rum. 'The ehiof montal quality of a horse is momory. One mujust stroke of the whip or a blow of your fist, and the horse is no lomere your friend. If you once forect to unfasten the holdlarek and let the herse enet ranght coming ont of the thills, you maty look for tromble "rere after.

\section{SUMMARY}

All horses are probably clerived from one stork.--The finest. horses were orieninally found in the East. Four common ty es of horses are: trotters, dratt horses, eoareh horses, and ponies.The different types of horses are the result of various eonclitions of life and of direent seleretion and breeding. - Imongr these noterl for speed are the Thoroughbered families, Hambletonian, Mambrino, and Morgan and stambardlored Trotter amel Pacer.--1)raft horses are the Percheron, Enerlish shire, ('yedestale, Belerian, ame Suffolk.-Popular breeds of roach horses are the French, (ierman, and Hackney ('oarh. - Three eommon breeds of pomies are the shetland, forthern Indian, and Bronee.-Derses are sensitire to unwise fording and fo hard usager. (are should be taken not to make them ill or lame.

\section{QUESTIONS}

I. Why is the horse important to the farmer?

2. Hais horse trotting been of the to the world? Why?

3. Why is it better to raise a blooded ente tham a "scrub)"? 


\title{
CHAPTER XVIII
}

\author{
SHEEP AND SIVINE
}

I42. Advantages of Sheep Raising.-On mally farms sheep may be raised with much profit. The sheep yiclds two valuable products, wool and meat. Both of these are always in demand. Sheep are valuable also to the soil in fertilizing pastures on which they feed, as well as in destroying weeds and underbrush. They can feed and be well nourished where cattle would find insufficient feed. They also eat a great variety of feed. In some ways, howerer, they are rather dainty feelers; they will not do well on stale feed. Wool of even cquality is not produeed unless conditions of feeding and care are good.

Experiments with sheep and eattle have shown that it costs less to add a pound of mutton to sheep than it does to add a poumd of boef to eattle. Cattle eat losis per thousand weight than sheep, but they do not gain so large a pereentage of their feed. At the ()hio $\mathrm{Ex}$ periment station it was shomm that it took $\$ .9$ pommdi of dry matter in feed to produce one pound of incerase? in live weight in eattle, and 7.37 pounds to produee one pound increase in lambs.

143. Breeds of Sheep.-Whecp were formerly linet almost entirely for their wool, and so the breeds are 


\section{AN INTROI)E(TION TO AORICTLTURE}

classified as short-wooled, medium-wooled, and longwooled. The principal short-wooled breed in the Inited states is the Merino. It is represented by several families, the most familiar being the Aneriean, Dedaine,

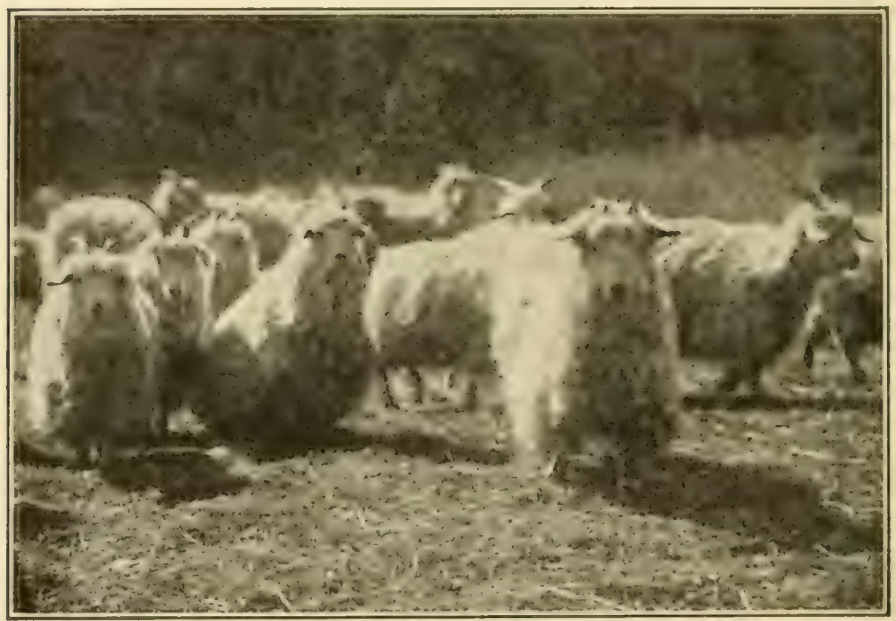

DAveNPoRTs, Long-wooled breed.

and Rambouillet. The Merinos originated in suain, and it is said that the robes of Roman emperors, two thousand years ago, were made from the fine wool of Merinos. The American produces a very fine wool on a very wrinkled body. It does not produce very good mutton. The Delaine has a smooth body and its wool is slightly longer and coarser in fiber than that of the American .Ierino, well adapted to carding. From this wool a fabric called Delaine is made. The Rambouillet is a French bred derived from Merinos imported from 
Spain. It is the largest of the Merinos, and is raised for mutton as well as for wool.

Among the medium-wooled breeds may be mentioned the Southdown, Shropshire, Dorset Itorn, Hampshire, and Oxford. The southdown is a thick-set sheep, hornles's, with face and legs of a grayish-brown color. It is the smallest of the "Down" or medium-wooled breeds. It is much raised for mutton. Individuals weigh one hundred and fifty to two hundred pounds, and produce a fleece weighing six to seven pounds.

The Shropshires are from the county of that name in England. The face and legs are darker colored than the southdowns; and the shropshires are heavier and yield more wool. They are much raised in the Missisiplpi Valley, being better adapted to withstand a wet climate than some others. Irany common herds are crossed with Shropshires with good results. After the Merinos they are the great American sheep.

The Dorset Horn is one of the well-established breeds of England. In the Tnited States it is kept in localities where the raising of lambs for the market is an important industry. It yields a rather light, short fleee.

The IIampshire is a black-faced breed, imported from England. It is hardy, a good grazer, and is widely scattered throughout Canada and United states. The lambs grow with great rapidity. The mutton is of good quality. The fleece is light, short, and inferior. The Suffolk Down is a large, black-faced, hornless, rangy sheep, originated in Suffolk Comty, Fugland. It is a relatively recent introduction to America. The wool is of good quality and the mutton is excellent. 


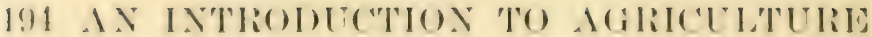

The oxford is the lareest of the medium-wooled sheep. It has a dark face and no horns. It is the sheepl best arlapted to foed on wet pastures. It is especially uscoul to produce mutton lambs to be marketed in early summer, at four to five months of age.

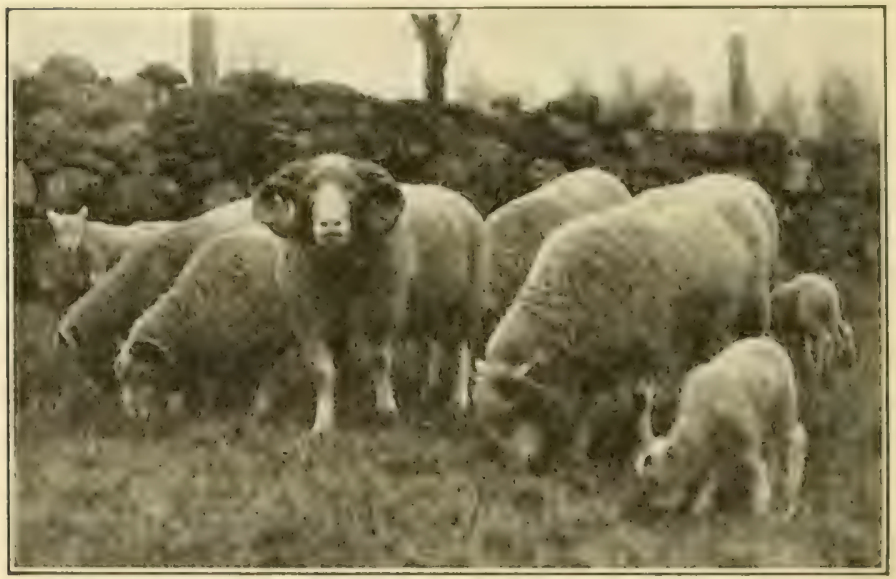

Dorset IIOnN SHEFP. Medium-wooled breed.

The lonerwoolerl breeds, represented by the ('heriot,

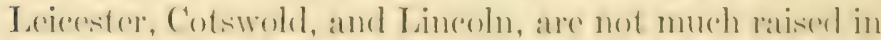
the Inited states. The Lineoln is one of the latrest of all brecels, mature rams sonnetinnes weighing two hundred and fifty pounds.

144. Advantages of Raising Swine.-Swine will change com and other foed info sallahle meat in less time and at less exprosere than perhays any orther farm animal. They will eonsume waste proluets, and are a geod side line on any farm. Mueh of this time they recpuire very 


\section{SHEEP AND SWINE}

little care. They also grub out the land and enrich it. For these reasons they are profitable stock to keep.

I45. Breeds of Swine. - Swine are classified ans larere, medium, and small breeds. The large breeds are the Chester White, Latrge Yorkishire, and 'Tamworth; the medium breseds, Berkshire, ('heshire, Inuroe dersey, Hampshire, Poland China, and Victoria; the small breeds, Essex, Small Yorkshire, and Suffolk.

The Chester White is largely distributed over the United states. It can he made to gain a pound a diay for two yours, but 150 to 5000 pounds is good weight. It

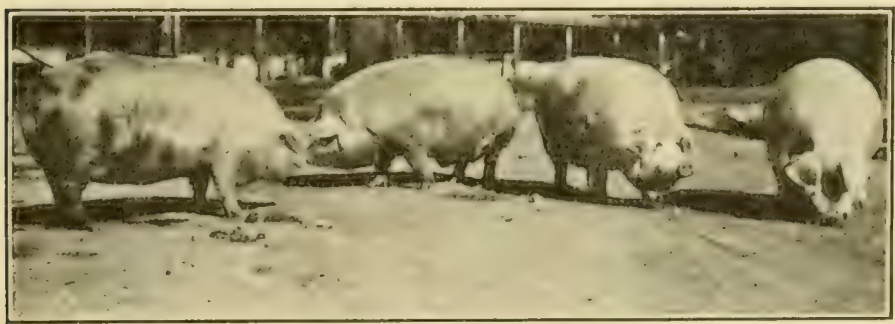

Chester Whites.

is esperially the fat hog or larel type, but makes fair bacon. It is grown especially in plates where hogs are kept in pens instead of in the field.

One of the most popular breeds is the P'olanct-('hina, which originated in ()hio. The color is black and white, the white being eonfined to the four feet, the tip of the tail, and the nose, in eood speeimens. The face is dished and the nose of mexlium length. These hogs are propulatr beratuse they are preaceable and strong-boned and fatten absily. They are of the latrd hog type. It is not un- 


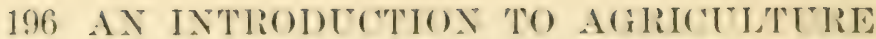

usual for one to weich two humeled and thirty pounds at six months.

In some parts of the Inited sitates the Inuroc Jersey is a popular hoer. The eolor varies from yollow to recl.

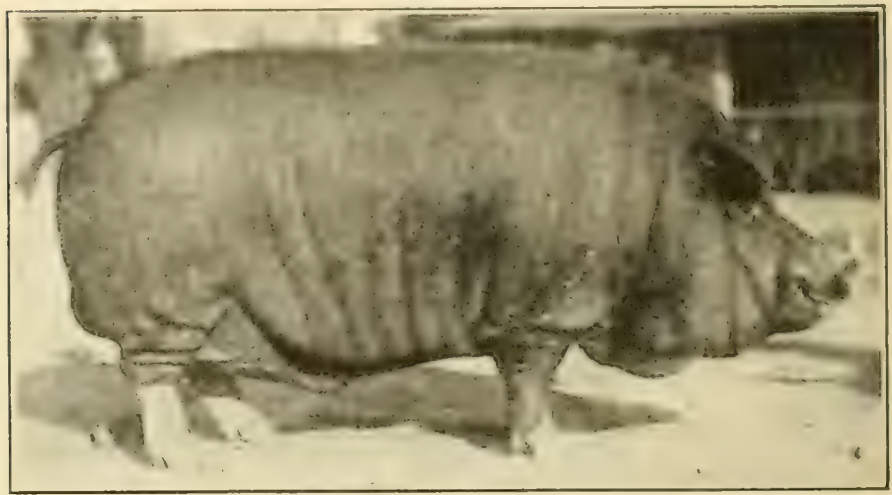

PotANi-CMINA.

cherry red being the standard eolor. This breed is rery hardy, prolifie, good mothers, and with geod disposition. There is more lean in their meat than in that of the Poland-(hina, but it is still of the lard type.

Perhaps no hog is more valued in America than the Berkshire, a fat hog type. The color is black, with white on face, feet, and tip of tail. The face is dished, and the ears generally carried ereet. The body has good depth and strength. It is widely seattered throughout Aneriea. The quality of the meat is high.

The Cheshire should also be mentioned. "The color" is white, head small and long, ears crect, hair thin, legs rather long, body long in propertion to the other climen- 
sions, bone fine." It is of Ameriean origin, and is of the fat hog type. The large Yorkshire, an English breed, is being raised where bacon hogs are in demand.

The small Yorkshire is widely raised, especially where hogs are kept in a pen. The nose is very short, and when the animal is fat the eyes are almost closed. It is generally killed and sold when it weighs about two hundred pounds. In feeding, it is generally "forced," or fattened as quickly as possible. It is a fat or lard hog, of little importance in America. The Suffolk closely resembles the small Yorkshire, and is of little importance in America. The Tamworth is a bacon hog, a golden red

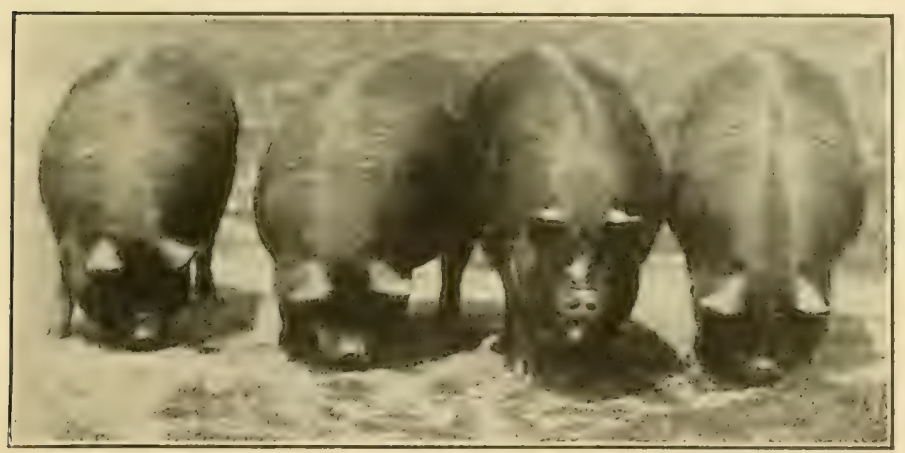

BERKSHIRES.

in eolor and little raised in I'nited States. The Victoria, a lard hog, is also little raised here. The Essex is another small breed that is beroming popular. The eolor is black, face short and dished, hair thin, eareass long and deep. The animal easily takes on fat. The Hampshire, valued both for bacon and for lard, is characterized by 
having a band of white encireling the leoly and inchuline the fore legs.

146. Where and How to Raise Swine.-The hog has been well called the morterage-lifter, and such it is in the great eorn belt extending from ( )hio to kiansis. The profit depends on the supply of eheaply erown eorn and the ability of the hoge to get about hall the needsity feed by erazing. Where the latter eondition is wanting the profits, at least in the llest and fouth, will be uneertain. There should be good grazing gromel, clean water, and shade. The souree of the drinking water supply should not be a wallowing place. The shade in summer should be from trees rather than buildings in order that there may be a breeze. Hogs thrive better in small droves, and if many are kept it is better to separate them tham to let them all run together. The breeding sows should be kept apart from the fattening herd.

Many keepers of hoges raise forage eropses, such as elover, oats, retch, cowpeas, and, in the south, sweet potatoes, peanuts, and chufa. It is better to raise a variety of erops on small tracts than only one kind. Some brecters have portable fenees to control the feeding. Salt and ashes should be supplied freely, and frequent change of foed is desirable. When grain is ferl it should not be thrown on soft groumel to be trampled in the mud. Short and ground feed should be wet and forl in a trough. Shelters for hogs will rary with the latitule and climate, but in all cases it is better to have a floor. Many farmers use portable hog house's.

It is foumd to be cheaper to raise two hoges weighing three hunderel pounds atch than one weighing six hum- 
dred pounds. Experiments have shown that there or four pounds of foed will add a pound to the weight of a hog under a hundred pounds, while more than five pounds of feed are required to put a pound of weight on a hog weighing over three hundred pounds. The most money is made by fattening as rapidly as possible, and if a hog is not gaining about a pound a day it should be sold. During the last six weeks eorn is the best grain to foed. Young pigs should be taught to eat some grain and forage even before they are weaned. $\perp$ few grains of soaked corn seattered on the floor will encourage them. Around the pen of the young pigs a plank should extend, raised a few inches from the floor to afford a protection for the pigs from their mother. Under this, soaked corn, shorts and oats may be seattered. Experiments have shown that the value of grain for hogs is increased if it is mixed with skimmed milk. skimmed milk is not only a good flesh produeer, but it also makes the grain more digestible. One bushel of corn and one hundred pounds of skimmed milk produeed, in a certain test, fifteen pounds of gain when fed separately, and eighteen pounds when mixed and fed.

When raising hogs for the market one should raise purc-bred or at least high-grade animals. The purebred hog will weigh nearly twiee as much on the same feed, and the loss in dressing will not be over twenty-five per cent, while the scrub hogr will lose one third.

\section{SUMMARY}

Sheep produce two valualle and necessary produetsmutton and wool-and are a benefit to the land.-Breeds of 


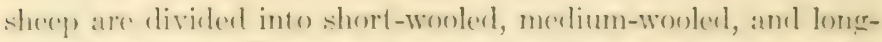
wereded breeds. -The short-wonled herels are represented by the Ilerines, divided inte the Imeriean, Delaine, and liambonillet families in the Enited sitates. - Imoner the mediumwowled breeds are the Southelown, Shropshere, Dorset Ilorn, Ilampshire, suffolk Down, and Oxfort.-The prineipal longwooled breeds in the United states are the cheriot, Leicester, Cotswold, and Lincoln.

The hog is a useful animal berause it is casily cared for, fitteneel, and sold.-Breeds of swine are describerl as larere, medium, and smatl.- Anomer the latere breests of swine are the Chester White, latrere Yorkshire, and Tamworth: among the medium hreeds, the Berkshire, (heshire, Homplnire, Vietoria, Poland-(hina, and I Huroc Jorsey; among the small breeds the Essex, Small Yorkshire, and Suffolk.

\section{PROBLEMS}

r. If ten lambs arain 0.45 poumd auch per day for 90 days, what is the total gain?

2. If the selling price wats $\$ 1.75$ per cwt., what was the total value of the gain?

3. If the average ceost of feed per pround of enain was 2.93 cents, what was the profit on the 10 lambs?

4. These lambs were one year old at the end of the !) days and averaged 125 pounds each. What were they worth?

5. The averatge weight of their flecee was 6.75 poumds, worth $11 \frac{1}{2}$ eents mowsherl. What was the total value of the wool and the lambs? 1

6. Ten pigs just weaned were ferl the following amount during a period of tS weeks: (oorn, 752 poumb at 70 cents per hundred; shorts, 579 pounds at 6i. cents per hunded; bone moal, 193 pounds at $\$ 1.50$ per hundred; milk, 2,317 pounds

1 These examples are made from data contained in Farmers' Bulletin No. 96, "Raising Sheep for Mutton," and refer to actual experiments made at the Iowa Experiment Station in 1900. 


\section{SHEEP AND SWINE}

at 15 cents per hundred. The total gain for the whole lot in 8 weeks was 5.33 pounds. (a) What was the cost of the feed for the eight weeks? (b) What was the cost per hundred of gain? (c) What was the gain worth at \$6.65) per hundred? (d) What was the net profit on the 10 pigs, leaving out the value of the work and interest on money invested? 


\title{
CHAPTER XTX
}

\author{
POULTRY AND BEES
}

I47. Benefits of Poultry Raising.-N Nhough the keeping of poultry is on the increase, yot there are many farmers who do not. realize its advantages. Poultry raising differs from many other farm ocerulations in that most of the work is light and may make pleasant activity for the young follis or even for the women on the farm. In fact, many women are suceessful poultry raisers and make their living in this way. Poultry furnishes for the family an abundance of food that is eatsily prepared. The raising of poultry may be done on small places, as very little land is necessary. Poultry raising can be started with small eapital, and eren the best-blooded stock may be secured by small outlay for exwers of purebred fowls. Poultry furnishes a variety of products, as orges for hatehing and cating, broilers, and adult fowls of various kinds; and sometimes the feathers are a source of income. All these products are abily marketer. The certainty of a market is amother good feature of the business, and at Thanksoriving and Christmas times the poultry raiser usually secures fancy prices. On the farm, much of the feed for poultry costs almost nothing.

Large numbers of insects are caten by the poultry 202 


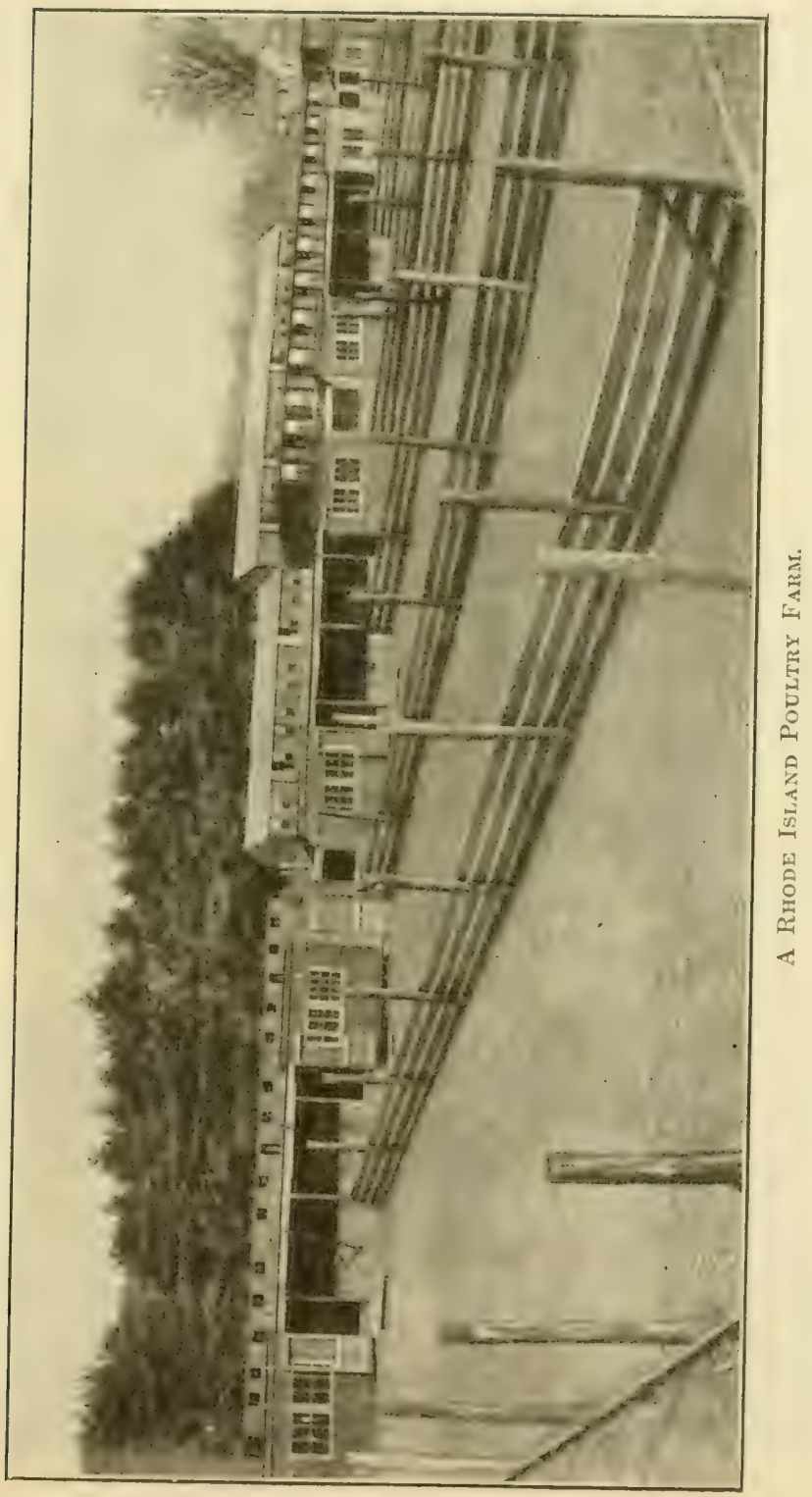


as they range over the farm. This is especially true of turkeys, which eat locusts and crickets in great numbers, besides pieking up the larve of many injurious insecets. Where geese are kepht the sale of feathers may be an item of special importance. It is eustomary to "pluek" the seese about four times a year. The feathers are heated and cleaned to make them ready for stuffing pillows and other articles. The feathers from other kinds of poultry are sometimes saved, but they are not so valuable.

The principal domestic fowls are chickens, ducks, geese, and turkeys.

148. Breeds of Chickens. - The breeds of chickens may be classified as egg breeds, meat breeds, and general purpose breeds. The principal egrg breeds are Leghorn, Minorea, Black Spanish, Blue Andalusian, Ancona, and IIoudan; the principal meat breeds, Brahma, Cochin, and Langshan; the principal general purpose breeds, Plymouth Rock, Wyandotte, Rhode Island Red, Java, and Dominique. Most of these breeds have two or more varieties.

The egg breeds are rather small, nervous, and lively. They are good foragers and are not inclined to sit. The'y like to run a good deal and should not he shut up too clusely. The Leghorms are black, white, buff, or brown, and have large eomls and wattles. The Leghoms are the most popular of the exor breeds. They lay white regres and many of them. The Minoreas are somemhat larger, and are black or white. They have large, single eombs. They lay well all the year round, and are fair table fowls. Houdans have a topknot of feathers, which 


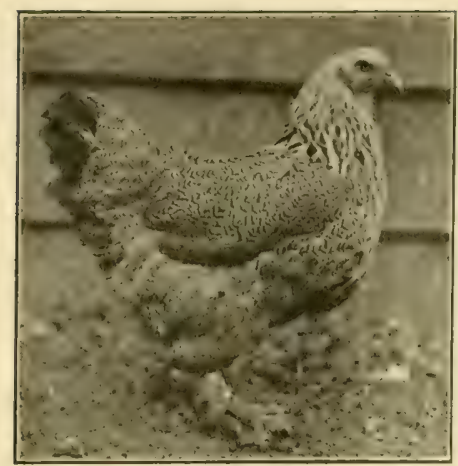

Brahma.

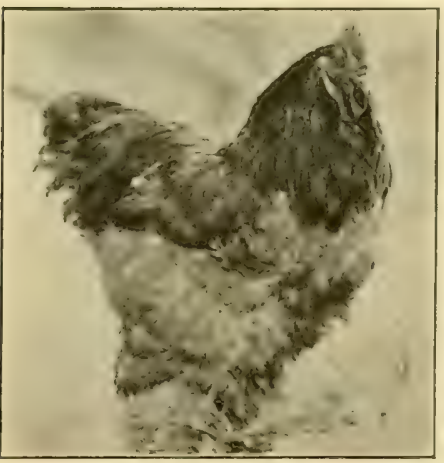

Buff Cochin.

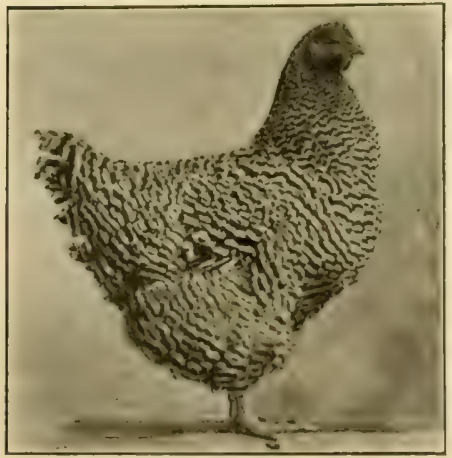

Barred Plymouth Rock.

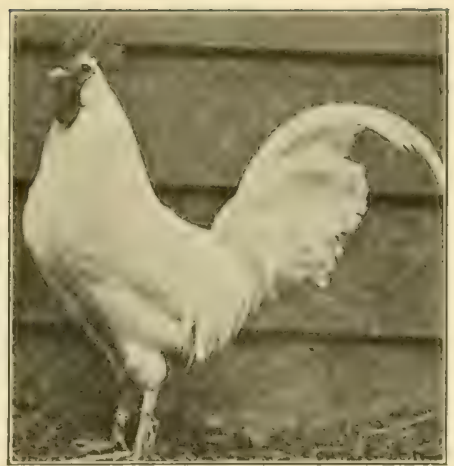

White Lechorn.

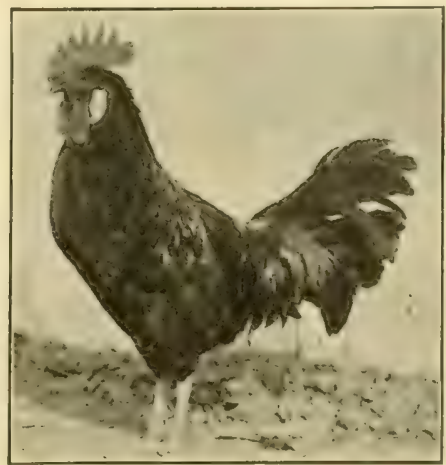

Minorea.

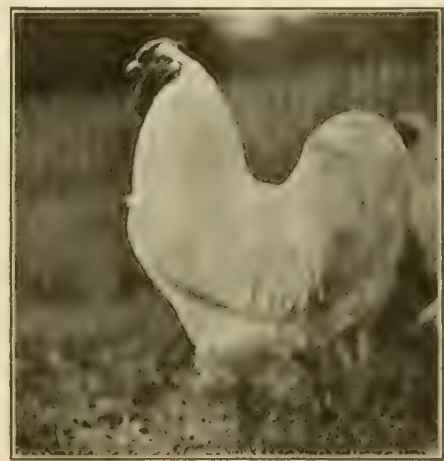

White Wyandotte.

Standard Bments of Chickens, 


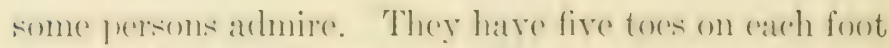
instoal of four. 'They lay woll, hut are not lieptet to any great rextent execpt for fancy purposes. They lay white egregs.

The meat brecels are less trim than the egen breeds, are not so active, lay fower erges, and are better sitters. The light Brahma is white with some black markings, and the shanks are foathered. There is also a rark variefy. In adclition to furmishing anood moat these hirds lay well, cypecially in winter. They are harely and casily raised. The Cochins have most of the good qualities of the Brahmas. They are smaller, but are hardy and good winter layers. There are four varieties, hlack, white, buff, and partrielge. The Buff Cochin is the most eommonly bred. The Langshan is breel in two varieties, black and white. It has long shanks, fewer feathers, and is more upstanding than the others.

The general purpose breeds combine many of the characteristies of the eger and the meat breeds, so that they are good or fair layers at the same time that they furmish a good supply of meat. The Plymouth Rocks are probably the most popular of all and are bred in three varieties, Barred, White, and Buff. I'erhaps the commonest variety is the Barred l'lymouth Rock. The color is erayish white with hlue-black lines rumbing aeross the feathers throughout the whole lenerth. The fowls are of molium size, smooth, and complate They make erome broilers at eieht or twolve werelis of ace and lay the year roment. The Il vandettes aresomewhat smaller tham the Plymouth linelis, and their flesh is comsiderend loy some to be better. This hread is hardy and does well even when 
shut up in a yard. There are several varieties. The other general purpose breeds are less popular in America.

I49. Ducks, Geese, and Turkeys.-Ducks and geese also may casily be raised on the farm. Iuckis erpecially require little eare as they are not so liable to discase as are chickens, nor troulled so much by vermin, and much of their food is that which no other farm animal will eat. Their feed should be given in a softened condition, as they do not have a crop for softening it. Water plants, snails, and the young of insects are the natural feed of ducks. It is not neessary to have water for duckis to swim in, and many persons prefer not to let them swim. There are many breeds of ducks, anong the more common being the Rouen, Pekin, Indian Rumner, and Muscovey. The more popular breeds of geese are the African, Embden, Toulouse, Chinese, and Canadian.

Turkeys bring the highest price of any meat from the farm, but more care is required in raising them than any other farm animal. There is, however, a sure market for them at certain seasons.

I50. Raising and Care of Poultry.-Like ererything else on the farm, poultry needs care and skill in raising if it is to be made profitable. Chickens should have a warm shed or house, free from drafts, in which to sleep and to stay in bad weather. They should

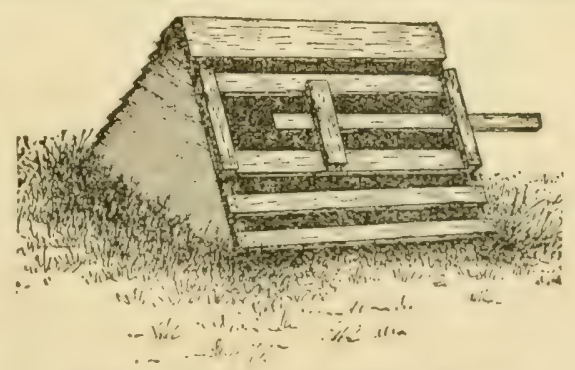

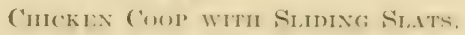


also hate a seratehing shed in which to exereise and a yard where they ean rum. If they are shut up, they

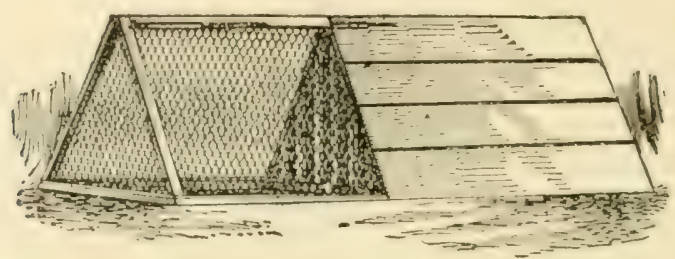

Chicken Coop witu Inclosed Ruv.

must be provided with ereen stuff to eat, and there must he gravere and sand to aat and dust to roll in.

On farms there are many green things that would go to waste if it were not for the poultry: unsalable beets, potatoes, carrots, cabbage, lettuce, peas, corne, and prool

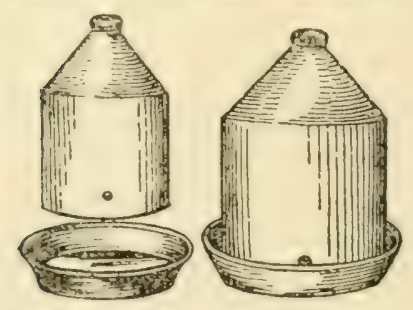

Iminking Forstain mate of a CAN. specimens of fruit may well be fed to the chickens. In winter, roots and tubers are desirable.

Turkeys are exceedingly frail when first hatched, and until they are quite large they must not be allowed to go out and get wet in the early dews. At first, they do not know enough to ait, and some persons put a chicken in with the brood to fumish an example for the young turkeys. Very often food is stuffed into their mouths. Turkeys wander far away, ceprecially to nest and rear their young:

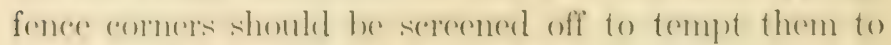
stay nearer heme. As the young get older and stronger, 
they must have a large tract to foed on, and therefore they cannot be raised in towns and villages ats chickens can.

I5I. Bees.--Bees get all of their food free of expense to the farmer; and though bees recuire ennsiderable care, it is generally not expended in feeding them. Among the flowers on which bees feed may be mentioned the elorers, basswond, buckwheat, locust, milkweed, diaisies, and other composite flowers, blossoms of fruit trees and shrubs, and cucumber blosioms in the ricinity of pickles factories, especially for fall feecling. Horse mint is an important bee flower in some sections.

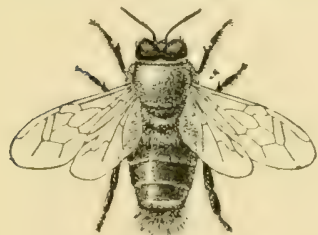

a

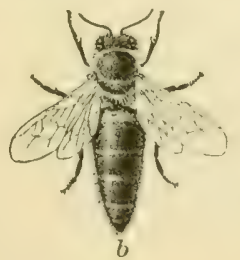

BEES. $a$, queen; $b$, drone; $c$, worker.

Each colony of bees contains a pueen, workers, and drones. The queen lays all the egrgs. The workers are imperfectly developed females, and gather honey, furmish wax and becbreal, make the combs and fill them, and feed the young bees. The chrones are the male bees and do no work.

The rueen lays one egre in each eoll and out of it hatehes the young bee or larra. This little insect alppears like a worm, and gets only what is foel to it. After a few days, the (oell is sealed up) and the larrat spins a silken covering or cocoon about itself. Then after 
ahout theres woeks it enmes out, an inseret with winges. The queen lays her erese in three linds of colls. Ont of the smallest cells eome the workers. From the next size eome the dromes, and in a few of the larerest cerlls are laded the erese that are to produee querens.

At certain times the hers, or most of them, in comgany with the queen, having their sales woll filled with honey, rush forth from their hive and "swarm," as we call

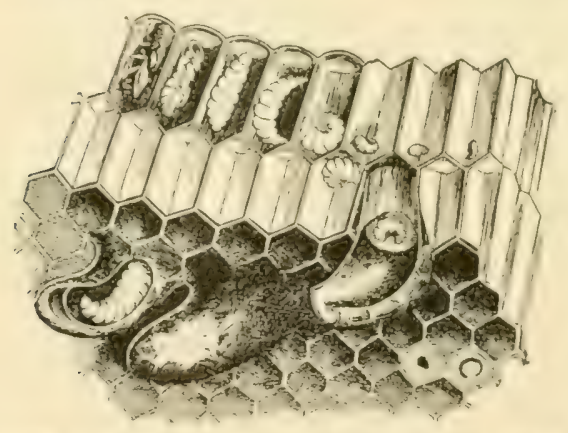

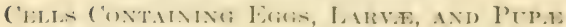
of the Honeybe. 'The lower large, irregular colls are queen cells. (Ifter bentoni.) it. 'This swarming may be eaused by the development of a new queen in the hive or by an oversupply of food so that there is no more space for them to fill, or by other causes we do not fully understanul. Ifter circling about in the air for a while they generally settle on a branch of a tree or hrush near hy. The here keeper must them geot them to settle in a new hive. Fometimes the hive is carried to the tree on whinh the bese have alighted, and if they are low enomeh they ean he exently hrusherl in. More frepuently the branch is ent off and carried to the hive, where the bees are crently shaken to the grement before the new hive and they find their way in. If, them, a little new or mufillerl (a)mb is fomel in the hive, something for them to go to work on, they will 
settle down and make it their home, and get to work. If bees are to be kept out of mischief, they must be kept busy. A modern way is to keep the queen's wings clipped so that she eamot fly away and will remain in the hive where she may easily be fomd and placed in the new hive. Then she is confined in a cueen cage and the swarm that has come from the old hive chusters there. Some apiarists do not allow their bees to swarm, but either place additions on the hives to give more room or divide the swarm. In the hives are placed morable frames in which the bees place their comb and fill it with honey. These frames are then removed and others put in their places. Some apiarists sell the honey in the comb and others extract it. Shallow hives are of the Danzenbaker or Heddon type, while the deep hive is of the Langstroth type, holding perhaps ten frames.

When bees are carefully managed the yield of honey will average fifty to one hundred pounds a year from each hive. If the season is poor, owing to dry weather or other causes, or if the swarm is small, the bees may not make enough honey to carry themselves over winter, and the bee keeper has none. Professor Hodge reports a hive that gained thirty-two pounds in weight in a single day during the flow of hasswool neetar. There is much water in this neetar which

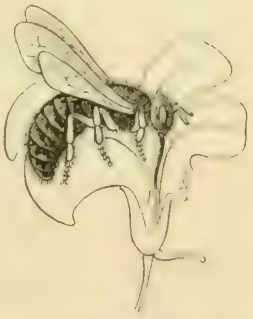

Diagram SHowiNa A J3EE CiMTING: IIon:Y. must be evaporated before it becomes honey. Bees should yield a profit of fire to tem dollars a year for each swarm, but honey, like many 


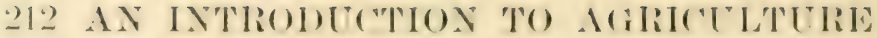

other articles produeed on the farm, does not always come up to our expectations.

\section{SUMMARY}

I'oultry raising is mostly light work and yiolds good profits with small outlay when properly eondueded. The work may be done on a small areat. There is no farm industry, however, more likely to be a failure in the hands of the eareless or unt rained.- Poultry yidels a variety of products for which there is always a good market.

The breeds of ehickens are dividerl into egg breeds, meat breesk, and general purpose breeds. - The prineipal breed of the first group is the Leghorn; of the second, the Brahma; and of the third, the Plymouth Rock.

Ducks and geese are easily raised and feed on many things that other animals do not eat.

('hicliens should have a warm shed for shelter and a sumny yard for scratching. They must be provided with green stuff and with grit to grind their food.

Turkeys recuire much eare when young and often have to be taught to eat.

Bees are profitable and of little expense on the farm. The honey stored by them is a good commercial product.

\section{QUESTIONS AND PROBLEMS}

I. In how many ways may poultry be valuable on a farm?

2. Why are winter livers the most valuable hens:?

3. How would you tell a Minorea from a Houdan?

4. Why are ducks profitable fowls to raise?

5. In what respeet do bees differ from the animals on the farm?

6. If eggess of a pure-bred hen for setting enst $\$ 1 . \bar{n} 0$ per. dozen, ame common exges 15 cents a dozen, and nine eages of each lot hatch, how much more does each chick of the blooded stock cost than of the common? 


\section{POULTRY AND BEES}

7. If a common pullet is worth 45 cents and a pure-bred pullet 75 cents, do the better eggs pay? How much?

8. How many more eggs per year at 15 cents jer dozen would the pure-bred hen have to lay to pay the extra cost of the egg from which she was hatched?

9. What is the value of a flock of 25 turkeys that dress on an average 13 pounds each, at 20 cents a pound?

ro. A merchant "candled" eggs by looking through each egg toward a light and found two bad ones in each dozen, which were rejected. If the eggs that were not " candled" sold for 20 cents a dozen, how much must be charged for the "candled" ones to receive the same profit?

Ir. Why would it be more just to sell eggs by the pound than it is to sell them by the dozen?

12. What are the advantages in hatching chickens early in the season?

13. What is the profit from a flock of 15 hens, if each hen lays during the year $200 \mathrm{eggs}$ selling at an average price of 20 cents a dozen, and if each hen eats one dollar's worth of feed per year?

14. If a hive of bees that costs \$5 swarms once and makes 30 pounds of honey at 1.5 cents per pound, what is the profit?

I5. On the first of May a hive of bees contains $20,000 \mathrm{im}-$ mature and mature workers. If the gueen lays 2,000 egges each day during the month of May and 1,500 workers die each day, how many workers will the hive contain on the first of June?

16. Why is a swarm of bees in Mlay worth more than a swarm in August? 


\section{CHAPTER XX}

\section{IRINCIPLES OF FEEDING AND CARE OF ANIMALS}

I52. Importance of Animal Food.-The animals on the farm are kept for certain definite purposes, as the horse for farm labor, the eow for milk or beef, the hen for egres. We give them food and care in order that the results or products may he gool. We might liken the animal to a machine by means of which the farmer grets certain products. The feed is the raw material from which the products are manufactured.

The products of the animal machine are: (1) heat; (2) new material to repair waste; (3) new material for growth; (4) egres or young; (5) extra fat or other tissue and secretions; (6) energy in the form of muscular labor.

The raw material, as we have said, is the feed of the animal. In the ease of milk, egres, and flesh, the product of one animal may be the raw material of another; and all animals use the products of plants as raw materials. The product of the corn plant is grains of corn, which are the raw material for the cow; the product of the cow is milk, which is the raw material for the calf; and the calf, in turn, may become the raw material for humin food in the form of veal.

The most important product, as far as the welfare of 


\section{FELDING AND CARE OF ANIMALS 215}

the animal is concerned, is animal heat or energy on which all other life processes depend. When this is supplied the other purposes of the food may be accomplished. This means that the animal must be given more than just enough food to keep it alive if we want it to keep up in flesh, to grow, to produce wool, eggs or young, to give milk, or to do work.

Careful experiments have shown that it is a wasteful practice to keep colts and other young stock out of

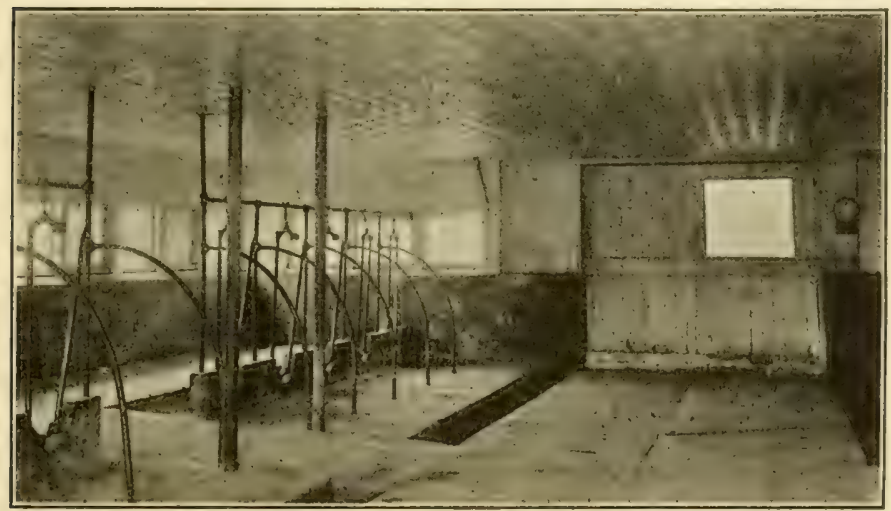

Model Cow Barn, Showing Tie-t'p with ('ement floor anid Thimd Walls and Ceilings.

doors in cold winters. It is useless to expect hens to lay eggs, or cows to give large (quantities of milk, when suffering from cold. It may even pay to take the chill off the drinking water in cold weather. Exposure to cold demands that a large proportion of the animal's feed be used merely as fuel, to keep up animal heat; and umnecessary exposure lessens the use that animals ean 
make of their fool for other purposes than body heat. Since energy is one of the important produets to be mained from feed, it follows that an animal that works hard must have more feed than one that is idle.

I53. Classes of Feeds. - It was stated in Chapter III that three of the constituents of plants are protein, carbohydrates, and fat. All of the protein compounds contain nitrogen. They are especially necessary in the formation of bones and musces. The fats and carbohyolrates are useful in supplying the body heat and enerey, and in storing up reserve materials for this purpose. The most important carbohychates are starch, sugar, and fibers (Sec. 56). Sugar and starch are easily digested, but fibers are less easily digested.

Nearly all the feed of animals is classified in these three groups. Before anyone ean use feeds intelligently, he must be able to tell into which class any feed falls. For example, corn contains ten per eent protein, five per cent oil, and seventy per cent carbohydrate, mostly starch, and is classified as a carbohydrate, since the carbohydrate compounds so greatly predominate. In making up a ration intelligently, therefore, the stockman must know how to choose his foods to gret a proper balance with the protein requirements of the animal. (Complete tables showing the composition of feeding stuffs will be found in the Appendix.)

The following is an aceount of the feed of "Yeksa Sunbeam" (Sec. 120) during the test.

During grazing season, excellent blue grass and clover pasture was supplied. In the late fall and spring of the year this was supplemented with some clover hay as roughage. In July 


\section{FEEDING AND CARE OF ANIIALA 217}

and August, 1905, during hot weather and fly time, oats and peas in the green state were fed as soiling ('rop), followed, in August and September, by green corn. During the winter season, while stabled, was fed from 25 to 30 pounds of corn silage made of corn that was planted so close together that the ears did not develop); also good elover hay and part of the time some alfalfa hay. Off and on during the winter she was fed some rutabagas.

The grain feed consisted of a mixture of grain made up of four parts wheat bran, two parts ground oats, two parts gluten feed, one part Old Process oil meal. Iuring the months of January, February, and March there was added to this mixture one part of corn meal. During the months of October, November, and December, 1904 , she was fed 15 pounds a day of this grain mixture. I Juring January, February, March, and April 14 pounds a day were fed; during Mity, 12 pounds; and during Jume the cquantity varied from 12 pounds to 6 pounds. For July, August, and september she was fed '2 to 10 pounds of this grain mixture.

\section{I54. Balanced Rations and the Nutritive Ratio.-All} animals require protein, carbohydrates, and oil or fats in the proper proportion; and skill in feeding consists in part in giving the feed in that proportion. A ration is a certain fixed portion of food dealt out to a person or an animal. When an animal's feed has the proper proportion of these three classes of foods for the purpose intended, it is said to be a balanced ration.

In balancing a ration and finding the nutritive ratio, the proportion of protein is compared with the proportion of carbohydrate and fats combined, and this comparison is generally written thus: $1: 7,1: 12$, indicating that there is one part of digestible protein to serem, or one part to twelve of digestible carbohydrates and fats, 
or "carbohydrate equivalents." Bycarbohydrate equiralent is meant the carbohydrate starch, sugar, and fiber) and fat expressed as an exulvalent value of rarbohyllate as an animal food. Fat is worth 2 t times as much as carbohylrate. Thus, \& pounds of fat would be worth 21 times 8 , or 18 pomeds of carbohydrate. If a ration had 12, pounds of starch and 4 pomels of fat, the carbohydrate equivalent would be $(2,-44)+$ 12 , or 21.

If this ration had also 2 pounds of protein, the mutritive ratio, that is, the ratio hetween the protein on the one hand and the earbohydrate equivalents on the other, would be 2:21 or $1: 10.5)$. This would be ealled a "wide" ratio because there is such a predominance of carhohychrates; 1:5 would be called a "narrow" ratio.

For horses at work, the mutritive ratio should be about $1: 6$ to $1: 7$, the former being for heavy work. For milch cows, the average of 12s Wiseonsin herels is given as $1 \cdot 6.9$. This is generally considered rather wide, and a ratio of about $1: 5.4$ is preferred for milch cows by many authorities. Wool sheep require a ration about $1: S$ or 1:9. Nimilar standards are set for other classes of animals. (See Table IV, Appendix.)

The table on page 250 of the Appendix gives the amounts of the different classes of feed comstituents in various fodders. The last columm of Table YI grives numbers representing the mereg value (that is, the value in producing (mergy) of foeding stuffis in calories. 1

${ }^{1}$ A calorie is the amount of heat repuired to warm one pound of water four degrees Fahrenheit; or in the metric system, one kilogram of water one degree centigrale. Such a unit as this has been 


\section{FEEITIO AND ('ARE OF INIMALA 219}

In calculating the enerery value of feeds, it is eustomary to consider that one pound of protein or carbohydrate produces 1,860 ealories, and that one pound of fat produces 4,220 calories.

The following may bo taken as a sample ration for a 900-pound dairy cow:

12.5 pounds timothy hay,

$\begin{array}{lll}7.5 & \text { " } & \text { corn fodder, } \\ 3 & \text { " } & \text { corn meal, } \\ 4 & \text { wheat bran, } \\ 2 & \text { " } & \text { cotton-seed meal. }\end{array}$

By referenee to Table VII of the Appendix the following results may be obtained:

\begin{tabular}{|c|c|c|c|}
\hline & $\begin{array}{l}\text { Total dry } \\
\text { matter. }\end{array}$ & Protein. & $\begin{array}{l}\text { Carbohy- } \\
\text { drates, etc. }\end{array}$ \\
\hline 12.5 pounds timothy hay ........ & 10.9 & 0.35 & 5.8 \\
\hline 7.5 pounds corn fodder, dry...... & 4.3 & 0.19 & 2.7 \\
\hline 3 pounds corn meal. . . . . . . . . . & 2.6 & 0.19 & 2.1 \\
\hline 4 pounds wheat bran..... & 3.5 & 0.48 & 1.8 \\
\hline 2 pounds cotton-seed meal........ & 1.8 & 0.80 & 0.8 \\
\hline Total pounds.............. & 23.1 & 2.01 & 13.2 \\
\hline
\end{tabular}

The other 7.89 pounds of dry matter is indigestible. The mutritive ratio of this ration is found by dividing 2.01 and 13.2 by 2.01. The puotients are $1: 6.5$. The number of ealories found by multiplying $2.01+13.2$ by 1860 is 28,290 .

found the most convenient with which to measure onergy. It is becoming customary to use the wort therm to denote 1,000 calorie's, as it allows the use of smaller numbers.

'The "etc." in the table refers to thr fut which has been reduced to carbohydrate equivalent l,y heing multiplied by $2 \frac{1}{4}$. 
By substituting red-elower haty for the timothy, there would be a gain of 0.54 pound of protein, making the protein 2.55 poumds, with a lose of only half a pound of earbohyclates. This change would make the ration eonform more nearly to the Wolff-Lohmam standards as shown by Table IV in the Appendix.

I55. Kinds of Feeding Stuffs.-For horses and cattle there is a great variety of feeding stuffs, roughly divided into ereen fodder's, silage, hay, and dry coarse

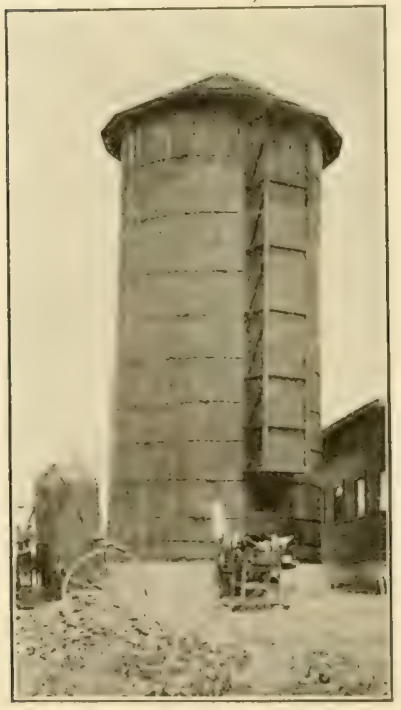

A SiLo. fodder, roots and tubers, grains and other seeds, mill products, and by-products. Only a few kinds will be mentioned under each head.

Green fodders consist of corn, rye fodder, oat fodder, oat grass, and the various well-known grasses, as redtop, orchard grass, timothy, alfalfa, and the clovers. Ensilage or silage (Sec. 104) may be of corn sorghum, soy beans, red elover, cowpeas, or certain other crops. Coarse fodder or "roughage" consists of dried corn fodder, barley hay, oat hay, and all the eommon forms of gratsis haty, and straw. Roots and tubers may be tumips, earrots, heets, or potatoes. The grains commonly used are corn, barley, buckwheat, peas, oats, rye, and wheat. 


\section{FEEDIN( ANI) (AIRE OF ANLUALA 221}

Mill products are corn meal, corn and coh meal, ground corn, oats, wheat bran, wheat middlings, rye bran, buckwheat bran, and buckwheat middlings. Byproducts are barley sereenings, shorts, millet sprouts, brewer's grains, gluten feeds, hominy chop, linseed meal, cotton-seed hulls, meal, and the like. Other miscellitneous feeds are cabbage, sugar-beet pulp, beet molasses, apple pomace, skimmed milk, and the like.

It will be seen by reference to Table $V$ of feeding stuffs in the Appendix that the grains have the largest amount of feed value per pound. For this reason they are sometimes called concentrates. The feed is so concentrated that it is necessary to feed roughage, as hay or straw, because the grains are not bulky enough to enable the animal's digestive apparatus to do its work properly.

The value of feed for heating the animal and for giving strength or energy to work is measured in calories. A horse at moderate work requires about 27,600 ealories. In figuring a ration, it is customary to compute the necessary protein and the number of ealories. Let us figure a ration for a 1,000-pound horse at moderate work. According to Table IV such a horse requires '2 pounds of protein and 27,600 calories. (Found by multiplying the carbohydrate value of the ration (14.85) by 1860.) Try

$$
\begin{aligned}
& 12 \frac{1}{2} \text { pounds of timothy hay, } \\
& 8 \text { " of oats, } \\
& 4 \text { " of corn. }
\end{aligned}
$$

From the convenience table on page $25 t$ we get the following contents: 


\begin{tabular}{|c|c|c|}
\hline & l'rotein, & | Carbohydrate, etc. \\
\hline $\begin{array}{cl}12 \frac{1}{2} \text { pounds timothy hay....... } \\
8 \\
4 & \text { onts... }\end{array}$ & $\begin{array}{l}.35 \\
.74 \\
.25\end{array}$ & $\begin{array}{l}5.8 \\
4.6 \\
2.9\end{array}$ \\
\hline Total .... & 1.34 & 13.3 \\
\hline
\end{tabular}

The nutritive ratio, found by dividing each quantity by 1.34 , is $1: 10$, nearly. Multiplying the sum of the proteins and earbohydrates, ete., 14.64 by 1,560 , we get 27,230 , the number of ealories of energy. The amount of protein is slightly under that given in the tahle, but is more nearly that actually fed to horses in the United States.

156. Profit and Loss in Feeding.-The main object in raising stock on the farm is to make money. All feeding should be done with the question in mind, "How much more will this feed be worth when changed into flesh or milk or other products, than it is now worth in its present shape?" If a costly feed is used when a cheaper would do just as well, there will be less profit, and perhaps a loss. The farmer should find out just how much and what is profitable to feed, and should use that and no more. Feeding tables based on thousands of experiments have been published, extracts from which will be found in the Appendix.

It will be seen from Table II that the feed of oxen at rest in the stall should have a wide ration, 1: 11, while that of milch cows should have a narrower ration, $1: 6$; and horses on light work $1: 7$, and on heary work $1: 6$.

It is to be understood that many farmers feed stock without knowing these things. Thousands of farmers 


\section{FEEDING AND CARE OF ANIMALS 223}

raised and fed stock successfully, learning by their own mistakes and experience, before these tables mere made out. So they mowed with a seythe and cut grain with a sickle. But in the matter of feeling, just as in mowing and reaping, it is better and cheaper to learn by other persons' experience and progress, and the farmer should be glad to learn all he can about economical feeding of his stock, for whatever purpose. He does not wish to make the horse fat or the hog active; he does want, with the least expenditure of feed, to make the hog fat and the horse strong. It is well for a feeder of animals to know how much is being fed. Many persons feed twenty or thirty pounds of hay to a horse besides his grain, when ten or twelve is all that is necessary. It is well for one to know how near the standard he is feeding.

If the pupil lives on a farm he should conduct a series of experiments in feeding. He may figure out a balanced ration for certain animals. He should weigh the feed, for he should at least learn the quantity being fed. If it is possible to weigh some animals at intervals, much interest and profit may arise from the work.

r57. Care of Animals.-Nearly as much depends on the proper care of farm animals as on the proper amount of feed. As was said at the beginning of the chapter, the first use of feed in cold weather is to keep the animal warm. If an animal is not properly protected and kept warm, the feed that should go to lay on fat, or increase the size and strength of the animal, or produce a product, is burned up for fuel. Many persons in the Northern States let colts run out all winter, but it has been found that such colts suffer in size and viegor. 


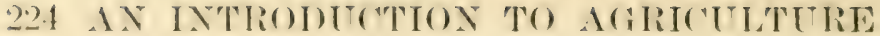

Animals should also be liept clean. In some states there are now laws forbichling the sale of milk from filthy stables. Amost everyone curries horses; as a matter of fact, currying does eattle just as much good.

There should be a proper allowance of room and fresh air for animals. A great many barns are too open and subject to draughts, while in others the stock is

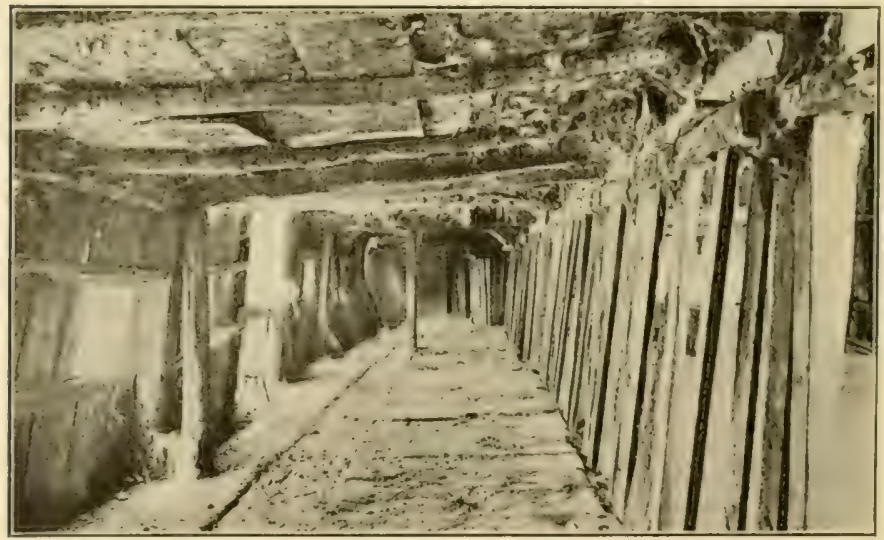

The-up witi Dirty, Defective Flook, Cemling, and Back.

crowded and the tie-mes are filthy and poorly ventilated. Animals need exereise also. Some years ago a Wisconsin farmer built a barn with the stables in the hasement, expeceting to keep the eattle there all the rear round. Ite fed shredded eorn. Findine after a few months' trial that most of his eows suffered from foot-rot. he decided to observe and follow nature a little more closely. 


\section{FEEDING AND CARE OF ANIMALA 25}

\section{SUMMARY}

The animal uses feed for maintenance, to produce heat, repair waste, and build up tissue. When these are satisfied, the surplus may be turned into work or production.

Feed may be classed as of three kinds according to its nature: protein, fats, and carbohydrates. - Fats and carbohydrates produce fat and energy, and protein produces muscle and bone.

An animal should have a certain amount of each kind of feed. The proper amount is called a balanced ration.-I balanced ration may be found from various kinds of feerling st uffs.

Animals are producers of energy. If energy is lost, there is less profit from the animal. The source of energy is the fred the animal eats. If the animal is not cared for or protected from the cold, energy is wasted.- The farmer should strive to save the energy produced by the animal.

\section{QUESTIONS}

I. Explain why an animal may properly be ealled a machine.

2. What are the raw materials of this "machine"?

3. Name some of the finished products.

4. Why should a cow be kept comfortably warm?

5. What are the three classes of feeds?

6. What is a balanced ration? Why is it important that an animal should have a balanced ration?

7. Which is the wider nutritive ratio, $1: 6$ or $1: 12$ ? What do these numbers mean?

8. Why is a hundred pounds of corn worth more than a hundred pounds of green fodder?

9. What is the nutritive ratio of the following ration for a horse? 7.5 pounds mixed hay, s pounds oats, $t$ pounds corn and cob. 


\section{CHAPTER XXI}

GOOD ROADS.-FORESTRY-HOME ANI) S('HOOL GROUNDS

158. The Farmer's Interest in Good Roads.-( )ne of the most important thingre in connection with life on the farm is a crood road. On the road the farmer must transport his produce to market, draw back his supplies, and travel to mill and to "meeting." Nothing contributes so surely to dislike of country and farm life as poor roads. The farmer plodding along in the mud, his team barely able to drag the load with harness, horses, and wagon a mass of dirt, pietures to himself his more fortunate brother in the city, using paved streets and emment wallis. He decides that he has had enough of farming, sells or rents the farm, and departs for the eity. It is muneessary to enlatere the pieture; it is ton woll known. During many days or even weeks of the year, the farmer and his family are shut away from town, from chureh, society, and entertainment. A large part of the trouble comes from the fact that most of the work on the roads has had only temporary effects.

159. How to Make and Keep a Road Good.-- Teraping a lot of sand and dirt and sod and rubbish into the road and leaving it for the passing teams to flatten never did, and never will, make a good road. If a large part 
of the work and money spent in the last twenty-five years in repairing and making dirt roads had been expended in doing a little each year and doing it well, every county in the Northern States might to-day have had its main thoroughfares in good condition. Much of the work done has really accomplished no good whatever to the roads, and they are often worse after than before repairs. The work on roads should consist in making good gravel or stone roads which are permanent in their nature.

There are certain foundation principles that should govern road-making and maintenance. The man who oversees the work should have scientific knowledge of

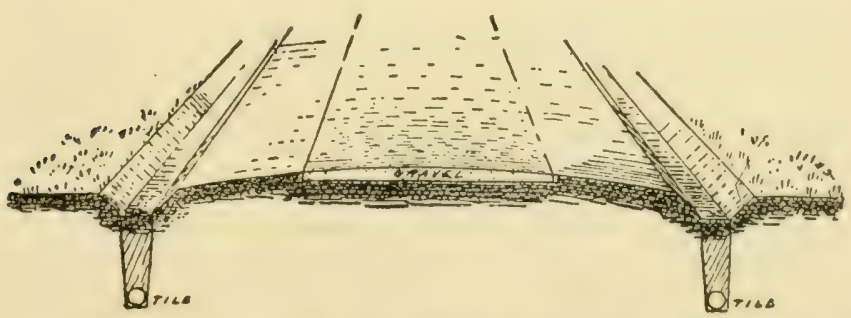

A Gravel Ruad Properly Crownen, with Side Ditches and Tile Drains.

how to make and maintain a good road. The material of the road should be graled, with the coarsest at the bottom; and the successive layers should be well rolled, compacted, and filled in with finer material. The road should be well drained.

But most important of all is to have a few workmen constantly making repairs. The railroad companies have learned that the only way to keep their roaks in 


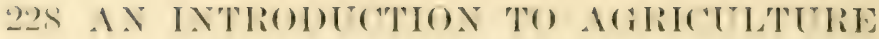

grood repair is to hate a "seretion gane" with a romgetent bosis constantly at work. Nothing made by man will last forever without attention and renewal, and a road is no exception. When a roal shows signs of beeoming rutty, the material should be hoed or dragged into the ruts I halfelay's work at the right time will save several days' work later and may lieep the road in goond condition. The roalmaster should make it a partieular point to examine the road in rainy weather. Ile should motice where the water collecets and should fill in surh places as soon as the conditions permit.

The material of which the roakls are made will depend on the locality and the financial condition of the inhabitants. Where it is possible, arushed stome should be uerel and a macadamized road built. In some states, the state assists and frecuently builds a sample streteh of road as a model. Many miles of such roads have been built in Massachusets. Where it is not possible to build stone roads, gravel may be used. There is a great difference in gravel roads, aceording to the kind of gravel and the plan of construction.

Much improvement might be marle in roads with little trouble if eountry boys would form the habit of kicking or throwing loose stones out of the road. These loose, round cobblestones are a great nuisanee in roads. Another way to keep roads good is by using only widetired wagons for heavy work and avoid driving in a single track.

The sides of the road should also reecive attention: the brush and weeds should be eut and lourned, not left as a harboring place for inserets. The large stoness should 
be removed, so that the roadside may be used for sleds and cutters when the snow melts or blows off the main part of the road. Attention should be given to the drainage so as to avoid pools of standing water which keep the road from drying out in spring and after rains. Fences should be kept in repair.

Acquire the habit of observing the roads traveled and of noting the condition and reasons for the good or bad condition.

I6o. The Purpose of Forestry.-Forestry is the art of so managing growing timber that it may be used continuously for the needs of man. It includes not only raising and care, but the handling of the grown crop, its product, and waste material. When the first settlers came to this country they found an almost unlinited amount of forest land. Four hundred years of eareless cutting have so devastated our forests that, unless some heroic efforts are made, forests will soon be no more. For this reason, the subject of forestry has recently been receiving much attention.

In forestry we study the conditions and length of time necessary to produce a forest, the best way to use and not. to destroy a forest, and methods of reforesting "cut-over" lands. Forestry includes also the study of the effects of forests on climate, including the winds, temperature, humidity of the air, rainfall, drainage, and other effects on the soil. The purpose of forestry is not to prevent the death or destruction of trees, for all trees must die, but to determine when to eut a tree so that it will be of most value to the owner, and will leave its place in the best condition to be oecupied by other trees. 


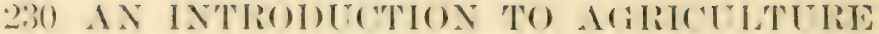

16r. Some Advantages of Forests.-It is now known that forests have an important influence on the climate. The air in a forest is some degrees warmer in winter and cooler in summer than the air in the open. 'The air in the forest is more nearly saturated with water than the air outside. These three conditions must affeet more or less the surrounding region. The trees and the

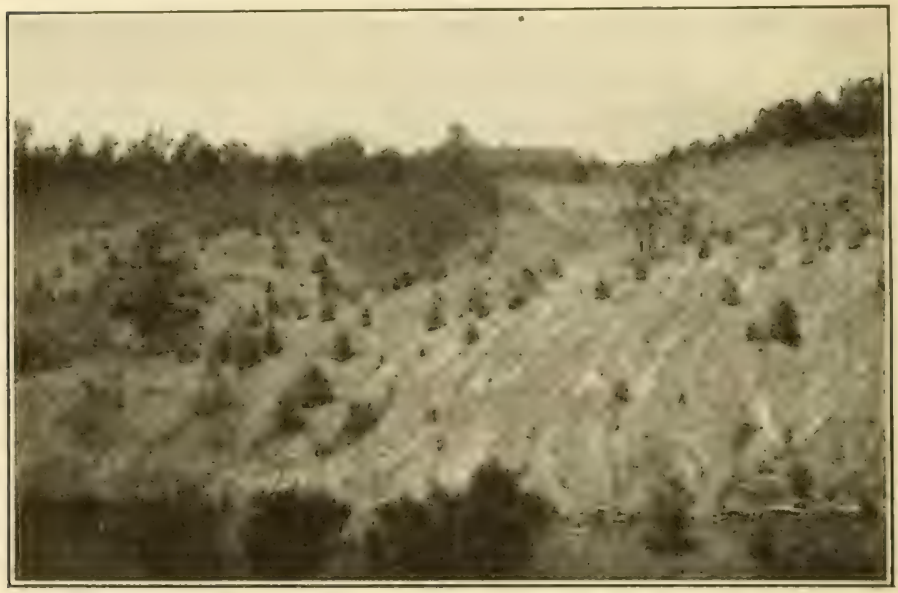

A Deforesten Him.sine.

This shows how the rain water runs of earrying the soil with it.

dead leaves on the eroumel catch the rain and hold it so that it does not rum off so rapoldy as it doesoutside, and thus floods are cheched. Eypalizing the flow of streams is a most important influenee of forests. Forests hinder (vaporation from the soil to a very great extent, depending on the amoment of leaf molel on the enromel. As a wind break the forest is very important in some? places. 
It has been elaimed by many that forests direetly increase the rainfall in the United states. ()n this point Pinchot's "Primer of Forestry," published by the United States Department of Agriculture, says: "The best evidence at hand fails to show a decrease in rainfall over the United States in the last hundred years, in spite of the cutting and burning of immense areas of forests; but it should not be forgotten that most of those areas have grown up again, first with brush and afterwards with trees. It is believed, however, that more rain falls over forests than over open country similarly placed; but how much it is impossible to say."

162. What Other Nations are Doing in Forestry.Almost every nation is doing something in the way of public forestry. Japan supports an efficient boly of foresters and has a forest school. Government forestry is well established in Austria, Italy, Norway, and Sweden. The same is true in Turkey, Greece, syain, and Portugal. Probably the most perfeet system is in Germany, where there are seven forestry schools. The forests yicld the nation a great income. France, also, has an effective system by which destructive floods have been prevented by the planting of trees.

Switzerland has one of the best systems in Furope, especially as a pattern for the United states. Forestry has been practiced there for six hundred years, and the public forests yield an annual return of about eight dollars per acere. The swiss laws "Are intended to work more thorough instruction, enood example, and ("ncouragement than by severe regulations." 


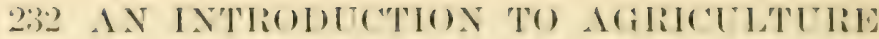

The forests in India under J3ritish eontrol are in chatege of 300 superior officers and 10,000 rangers, and yield an anmual net income of over $\$ 3,0000,000$. It is said that 30,000 sefuare miles are protereted against fire at a yearly cost of less than half a rent per acre.

163. What Our Government is Doing.- There are in the Inited ritates more than $500,000,000$ aceres of forests. For somewhat over one hundred years the Inited sitates has made some effort to preserve the public forests. Even as far hack as 1653, "the authorities of ('harles. town, Mass. forbade the entting of timber on town lands without permission." In 1799, Congress appropriated $\$ 200,000$ for the purchase and preservation of timber land to supply ship timber for the navy. In 1891, an act was passed which was the first step toward a true poliey for the forests of the mation. This act contained a clatse which authorized the President to reserve timber land on the public domain. There are now sixty-two such reserves of public timber lands, covering an area of $62,000,000$ acese. Their we is to protect drainage basins used for irrigating, supply grass and forage for herds of cattle, and supply wood and lumber for settlers.

Forest Siervice is the name of the forestry hranch of the Inited states 1)epartment of Aerioulture. The "serviee" is making a map of the distribution of tree. species in the United States, studying the value of different trees, such as those producoing tanbark, willows for baskets, and pines for turpentine. The officers are supervisors, rancers, and guards, with deputies. Owners of timber land are griven adviee in regard to the lest 
methods of managing their forests. A study is made of forest products and the extension of forests.

r6. How a Forest May Be Perpetuated.-Several methods are in use to perpetuate a forest. One method consists in dividing it into small sections and cutting one section clean each year. New trees, self-sown, will grow up; and after many years the forest will consist

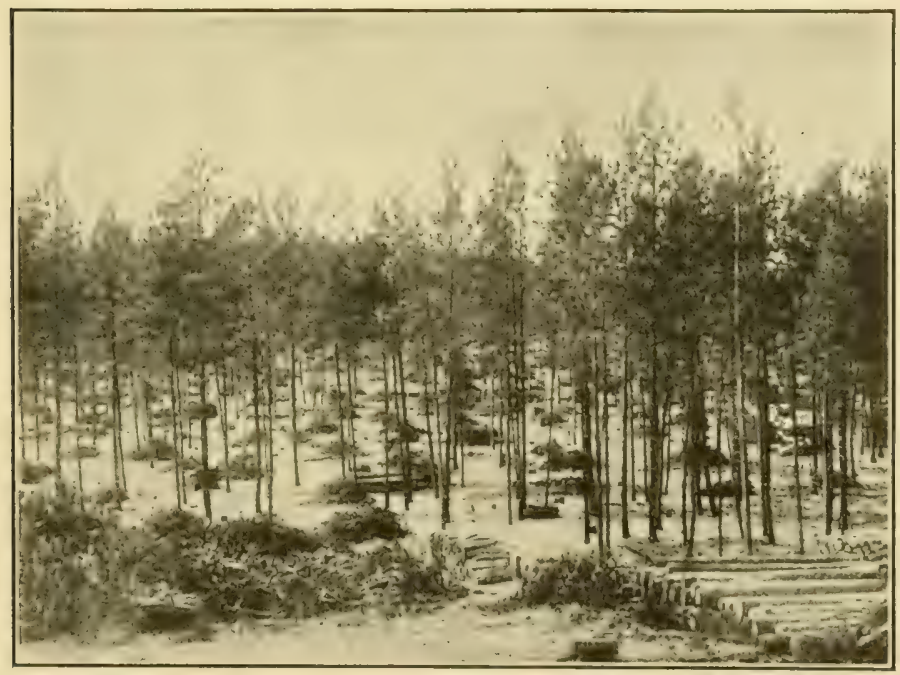

A Forest Properly Logged Under the Fomest Service RegulaTIONs. The young growth is uninjured and the brush is piled ready for burning.

of areas in which the trees differ in age by one year. For example, it is found that eertain trees will grow large enough for railroal ties in thirty-five years. By dividing a forest into thirty-five tracts and cutting off one tract each year, the supply could be made prer- 


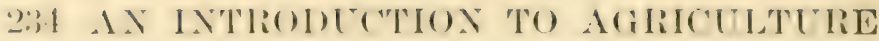

petual. Sometimes the trees for eutting are selected from the whole forest, the same groumd heing gone over year after year. Sometimes a strip onr hundred yarls wille or thereabouts is eut out and then allowed to grow up again.

Berome accuainted with the trees in your vicinity and know the names of some of them.

I65. Home and School Grounds.-. Many schoolhouses and some farmhouses are situated on plots of ground that are destitute of trees and shrubs. The sun beats on the buildings in the summer and the wind is unbroken in the winter. Nothing but barrenness is visible. If the objects that are daily seen impress our lives and help to form our characters, then here is an opportunity to impress beauty rather than its opposite quality.

The work in school agriculture ought to create a desire in the pupils to clean up) and beautify the home and school grounds. From the negrlected vards the tall grass and weeds should be mowed, and the large weeds pulled up by the roots; the dead leaves and weeds should be raked into piles, the other rubbish gathered up, and all burned or removed. Girass seed should then be sown. Leon if nothing further is done, most fremises will repay such work by their improved appearance.

I66. Trees and Shrubs.-Trees and shrubs look better, as a rule, when planted in groups or clumpls, rather than seattered singly around the heme or school-

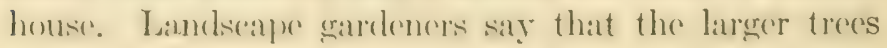


and shrubs should be in the background as a setting for the buildings, with low shrubs near the buildings and open spaces with grass in front. Often trees or shruls can be used on the boundaries in place of unsightly fences. It is a good plan to use trees or tall shrubs to hide the unsightly parts of buildings and outhouses, In sclecting trees, find some that are hardy and will live readily in your locality. Some trees grow rapidly but will not live long, and usually prove unsatisfactory. The American white elm (not the red elm) and the hard maple (not the soft maple) are two standards for most localities. The basswood, or American linden, is a dosirable tree because it grows rapidly and is also hardy. The blossoms are visited by honeybees, which make excellent honey from the nectar in them. The ash trees are quite satisfactory in the Northern States, as are also the sycamore, mulberry, walnut, Norway mapule, horse-chestnut, and beech. For places in the south the catalpa, tulip tree, the cucumber tree and the sweet gum may be adcled to the list. If the buildings need proteretion from the winter winds, then evergreen trees make a good wind-break. The Norway spruce is ruite satisfactory for this purpose; the Colorado blue spruce is perhaps more ormamental but not (quite so vigorous in all climates. The blue spruce is often userd as an ornamental tree. Directions for transplanting trees were given on page 154 .

In choosing shrubs, choose hardy ones. Wild shruls that grow in the locality are often the best for the purpose. Often there is some one in the neightorhoorl or district who has had experience in growing shruls in his 


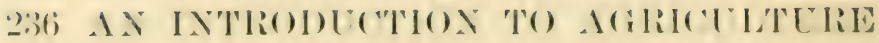

home yard. Such a person will generally be shat to help) in choosing suitable shrubs, and sometimes can supply the plants from his own yard. Do not depend entirely upon the descriptions in catalogues, or upon the advice of agents who are canvalsing for shrubs and trees. Shet out principally such shrubs as, experience has shown will grow well in your locality.

some of the shrubs that are used in many localities and have proved satisfactory are species of spirea, barberry, homeysuckle, weigela, lilae, snowhall, doubleflowering erab or plum, mock orange, sumach, dogwood, and currants. There are many different species of these shrubs, some being better adapted to one purpose and others to different ones. If it is desired to form a hedge, the common barberry, lilac, bush honeysuckle, arborvitae, elderberries, or others similar in character, will be found suitable. If there is a corner that can be filled with shrubs, tall ones should be set out in the rear and low ones in the front. The Japanese barberry is a pretty dwarf variety, and IVaterer's spirea is very desirable as a low shrub), while the rose-colored weigela, tartarian honeysuckle and mock orange are taller and suitable for places in the background.

I67. Vines. -There are many climbing plants that can be used to make a yard beautiful. This is especially true around porches, orer the deors, along walls, on arbors, or to cover unsightly objects. (limbing roses, clematis, Virginia creeper, bittersweet, English ivy, Boston ivy, climbing honeysuckle, wistaria, trumpet ereeper, and wild grapevine are all suitable for use. A word of caution is needed here, as well as at all points 
in gardening, that eare must be exereised in the arrangement of the plants, or the results will be unsatisfactory. Each vine has its own beauty, determined by its form, leaves, and blossoms. The effect desired in any given place must determine the kind to be planted. There are a number of annual climbers that may be used in some places with good effect, such as morning-crlory, wild cucumber, cinnamon-vine, moon-vine, and Madeira.

I68. Flower Garden.-Flowers should be raised in the garden or close to the sides of the house, but not in front or in beds on the lawn. It is as a rule better to leave the lawn directly in front of the house clear of trees, shrubs, and flowers, but at the sides and rear treess and shrubs may be arranged according to some plan, and the shrubs may be bordered with flowers.

One of the most interesting flower beds may be made from the native flowers which grow in the vieinity. If a shady cormer can be found, ferns make a very satisfactory background near buildings. Violets will usually thrive if transplanted with care; bloodroot, anemone's, hepatica, spring beauties, pasque flowers, columbine, and many other flowers can be added. Ferns of ten ean be added to such a bed with good effect. This is an ( $\mathrm{x}$ cellent flower bed for a school yard, as the children can dig up the specimens for the bed and tend to them as they grow. The blossoms also will appear early in the spring, before the vacation begins.

Old-fashioned flowers can be grown with satisfaction in the flower garden. Inollyhocks, phlox, dahlias, sunflowers, pinks, nasturtiums, stocks, verbenias, mignonette, larkspur, and candytuft represent a partial list 


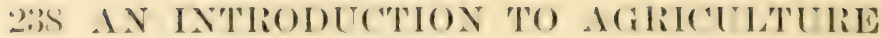

from which seleetions may be made. These are more stutable for the flower garden at home than at school. some of these are suitable for borders along walks where shrubs are used in the backeground.

In place of sowing seeds as for the above-named plants, bulbs may be set out. A bulb is a short underground stem having buds and many seales, which represont leaves. Many of the early-flowering plants come from bulbs, in which much food has been stored in the scales. The erocus is the earliest of these plants to bloom out-of-doors in the spring. The hyacinths, tulips, narcissi, and lilies are very satisfactory. These bulbs should be planted in the ground in the autumn before the around freezes. They will be ready to start with the first warm spring days. If the winters are very severe it may be best to cover the ground with leaves to protect the bulbs.

The most satisfactory flower gardens are those that are laid out in accordanee with approved plans. There is as much opportunity for the display of good taste in this matter as in the furnishing of the inside of the house. Landscape gardening is being studied by many persons, and more and more grounds are being planned so as to produce a harmonious effect with the building and its surroundings.

There are many hardy plants that may be used in chumps in platee of the bedding plants. The bedding plants must be renewed every year, and it is always late before they ean be started. The hatdy ones live over the winter, and increase from yoar to year. The investment here is a permanent one, while the other 


\section{HOME $\triangle$ ND SCIIOOL (IROUNTS 239}

plants must be renewed each year. The hardy plants are much easier of eultivation than the bedeling plants. A list of herbs and shrubs is given by a landseape gardener:

HARDY PERENNIALS FOR THE FARIIER'S FLOWER GARDEN

Aconitum autumnale (Monkshood).

Aquilegia (Columbine).

Althea (Hollyhocks).

Delphinium formosum (Larkspur).

Dicentra spectabilis (Bleeding Heart).

Funkia subeordata (Plantain Lily).

Hemerocallis flava (Lemon Lily).

Iris (iermanica, named varjeties (especially Florentina, Matdame Chereau, and Silver King).

Lilium superbum.

Monarda didyma (Bergamot).

Peonies, Chinese (espercially Festiva Maxima and Lady Leonora Bramwell).

Papaver orientale (Oriental Poppy).

Platycodon grandiflora.

Phlox decussata (esperially Lothair and Miss Lingard).

Pyrethrum uliginosum (Great Daisy).

Rudbeckia (Golden Glow).

HARDY FLOWERING SIIRUBS BEST ADAPTED T() THF FARMER'S GARDEN AND LAWN

Chionanthus Virginica (White Fringe Tree).

Dentzia Lemoinei.

Hydrangea grandiflora.

Lenicera bella candida (Honeysuckle).

Philadelphus grandiflora (Syringa).

Spirea Japonica, variety "Anthony Waterer."

Spirea thunbergii. 


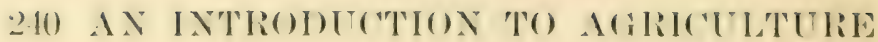

Spirea Van Houttei (Bridal Wreath).

Symphoricarpus racemosa (Snowberry).

syringa vulgaris (Lilate), especlially "Presilent (irevy" and Frau Bertha Damman.

Syringa Japonica (Japanese 'Tree Lilac).

Viburnum opulus (High-bush Cranberry).

Viburnum opulus sterilis (Snowball).

Weigela rosea.

Weigela Eva Rathke.

The care of the flower garden is not materially different from that of the vegetable garelen. The directions griven there for the preparation of the soil and its subsoruent troatment will also app)ly here. The soil should not be rultivated (lecp) enough to disturh the roots, but the gromel must be kept free from weeds.

Make a plan for improving the grounds about your schoolhouse, or some other building. Start the work.

I69. Conclusion.-The earpenter or other mechanice works upon his material, wood, metal, leather, or fabric, and sees it rhange under his hand to a thing of use or beauty. But these materials are lifeless and passive. The farmer, on the other hamel, is dealing with things that not only ean he change, but they themselves have life and respond to his efforts, coöperating with him to produce every product of the amimal and vergetable kingdoms.

\section{SUMMARY}

One of the most important things to a farmer is a good road. - A rood road is one that is hard and serviceable in all weather and seasons.-The way to hatre a good roud is to build it right, of the right material, and to keep it in repair. 


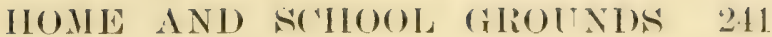

Forestry is the art of forming or of cultivating forests... Forestis are, next to the earth, the most important possessions of mankind. They affect the elimate and water supply.Nearly every nation in Europe gives much attention to forestry. -The United States has sixty-two forest reserves.

School agriculture should create a desire to beautify school and home grounds.- (ienerally the first thing to do is to rake up and clear away rubbish.- Shrubs and plants should be set out on the borders, leaving large open spaces covered with closely mowed grass. - Varieties of plants that are known to be hardy in a given locality should be set out.-Vines are useful for arbors, on walls, and to cover unsightly objects.-The flower garden is the place for flower beds rather than the lawn.A bed of wild flowers is very satisfactory.-Old-fashioned flowers should have a place.-Bulbs yield early flowers. 



\section{APPENDIX}

\section{INSECTICIDES AND FUNGICIDES}

\section{Bordeaux Mrxture for Blights}

The following directions for making Bordeaux mixture should be strietly followed to obtain the best results: Dissolve four pounds of copper sulphate (bluestone, blue vitriol) in twenty-five gallons of water, suspending it in a coarse gunny sack near the surface of the water. In a wooden pail slack six pounds of fresh quicklime in sufficient water, then add enough water to make twenty-five gallons and then slowly pour the two solutions simultaneously into the barrel from which it is to be used. If a larger tank is used, proportionately larger quantities of materials should be taken. Before pouring the lime solution, it should be strained through a coarse gunny sack, otherwise particles of rock and undissolved lime will get into the mixture and $\log$ the nozzles in spraying. It is very important that the two ingredients be mixed as described, otherwise the proper combination of eopuer sulphate and lime does not take place.

The mixture should never be made more than a few hours in advance of applieation. It cammot be kept over; and if any is left in the spraying mathine after the day's work is done, it should be emptied. 


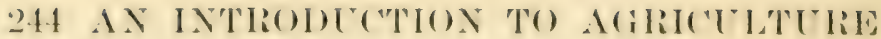

\section{How to Treat Seed Oats to Prevent Smut ${ }^{1}$}

\section{Formaldchyde Solution}

If the desire is to sow forty bushels of seed oats or less, seaure from your drugerist one pint of formaldehyde. P'ut into a barrel or tank thirty-six gallons of water and pour in the pint of formaldehyde liquid and stir thoroughly; next fill a gunny sack with the seed oats and submerge it in the solution for ten minutes; then lift the salch from the barrel and allow it to drain for a minute or two in order to save the solution. Empty the oats on a thrashing floor or on some outside platform to dry, and repeat until all is treated; shovel the treated grain over at intervals until dry or nearly dry before sowing.

If a large quantity of seed is to be treated the work will be facilitated by having several barrels or a large tank which will hold a number of sacks of oats, so as to treat several bushels every ten minutes. The time saved by having an abundant supply of the solution in the tank or barrels will more than repay the extra expense of the formaldehyle purchased. The oats must always be completely submerged for ten minutes.

It is well to treat seed grain several days before sowing in order to give it ample time to dry, or diffieulty may be experienced when sowing with secder or drill. If sown while damp the seeder or drill should be set so that it will sow about one bushel more per acre than when sowing dry oats.

The formaldehyde solution here recommended is not poisonous to farm animals and will not injure sacks or clothing eoming in contact. with it. Oats treated with formaldehyde solution and not used for seed may be fed to stock, but when so fed should be mixed with other oats.

The treatment of oats here resommended facilitates the

${ }^{1}$ From "O)at smut in Wisconsin," Bulletin $9 \mathrm{~s}$, Wisconsin Agricultural Experiment Station. 
sprouting and gives the grain a healthy appearance, readily distinguished by any observer. It is possible that the treatment kills other disease germs of which we as yet have no knowledge.

\section{How to Treat Scabey Seed Potatoes}

"Make the proper solution by pouring one pint of formaldehyde into twenty-five gallons of water. Distribute the liquict into several casks and into these casks put the uncut seed potatoes. The potatoes should be placed in gunny sacks and completely covered by the liquid and left for two hours. If the potatoes are very scabby leave for two and a half hours. The potatoes should then be planted in ground that has not in previous years grown scabby potatoes."-Wisconsin Experiment Station Bulletin.

\section{Kerosene Emulsion}

Kerosene emulsion contains the following ingredients:

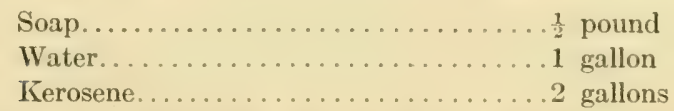

The soap is cut into thin shatrings and dissolved in hot soft water, and this is then thoroughly mixed with the kerosene by being pumped back on itself with a force pump. Small quantities, as a quart or more, may be mixed with a "Dover" eggbeater. This emulsion is to be diluted fifteen to twenty times its bulk in the growing season, but in winter it may be used very strong for scale insects. If the emulsion sets it must be heated before dilution. Any good hard soap may be used.

\section{Paris Green}

Paris green is used for all biting and chewing insects, the mixture being in the proportion of one pound of Paris green to 150 gallons of water. Paris green is frequently added to Bor- 


\section{AN INTIRIOE(TION TO AGRIOTLTELE}

deaux mixture. In this way plant diseases are prevented, and the ravages of insects are lessened by one spraying.

\section{TABLES}

Thble I.-Sinh Constituents Contaned in Average Crops per ACre

(From Tables of A. D. Hall, Director of Rothamsted Experiment Station)

\begin{tabular}{|c|c|c|c|c|c|}
\hline Crop. & WHEAT & BarLey & Swefpes & Mangeis & HAY \\
\hline & Tons: 2.2 & 2. & 30,1 & 30.1 & 1.5 \\
\hline Nitrogen. & l.b.: 50.0 & 49.0 & 98.0 & 149.0 & 49.0 \\
\hline Soda. & Lh.: 2.6 & 5.0 & 32.0 & 118.7 & 9.2 \\
\hline Potash & Lb.: 28.8 & 35.7 & 79.7 & 300.7 & 50.9 \\
\hline Magnesia.. & Ib.: 7.1 & 6.9 & 9.2 & 42.5 & 14.4 \\
\hline Phosphoric Acid. & Lb.: 21.1 & 20.7 & 21.7 & 52.9 & 12.3 \\
\hline Sulphur.......... & Lb:: $\quad 7.8$ & 6.1 & 17.8 & 14.0 & 5.7 \\
\hline Chlorine........ & Lb.: $\quad 2.5$ & 4. 1 & 15.1 & 83.1 & 14.6 \\
\hline Silica.......... & I.t.: 96.9 & 68.6 & 6.7 & 17.9 & 56.9 \\
\hline
\end{tabular}

Table II.-Fenthity Removen by Different Coror's

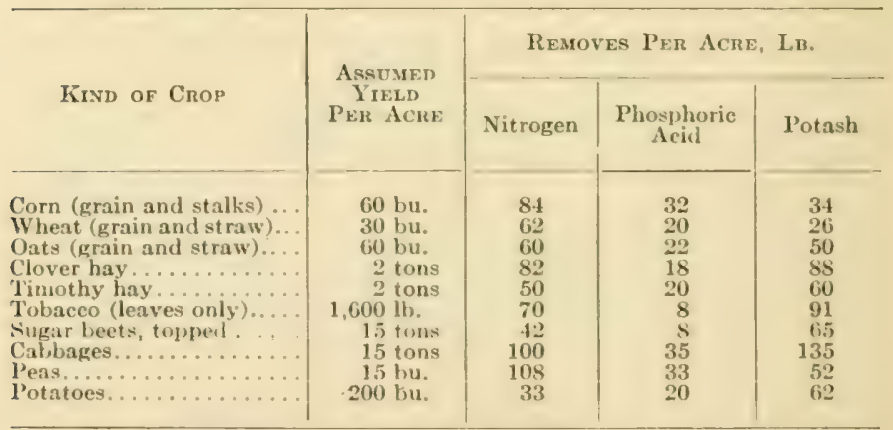

${ }^{1}$ From Bulletin No. 13.t, University of Wisconsin Agricultural Experiment Station, "Licensed Commercial Fertilizers and Feeding Stuffs." 


\title{
Table III.-Space and Quantities of Seed Required
}

\author{
NAME \\ Space and Quantity of Seens
}

Asparagus.......... oz. produces 1,000 plants, and requires a bed $12 \mathrm{ft}$. square.

Asparagus Roots......1,000 plant a bed 4 feet wide and 225 feet long.

English Dwarf Beans ... 1 quart plants 100 to 150 feet of row.

French Dwarf Beans.... 1 quart plants 250 to 350 feet of row.

Beans, pole, large...... 1 quart plants 100 hills.

Beans, pole, small . . . . . . 1 quart plants 39 hills or 250 feet of row.

I3eets............. $10 \mathrm{lb}$, to the acre, $1 \mathrm{oz}$. plants 150 feet of ruw,

Broccoli and Kale..... 1 oz, plants 2,500 plants, and requires $40 \mathrm{sq}$. $\mathrm{ft}$. of ground.

Cabbage............ Early sorts same as broccoli, and require $60 \mathrm{sq.} \mathrm{ft.} \mathrm{of}$ ground.

Cauliflower......... The same as cabbage.

Carrot...............

Celery............ 1 oz. plants 2,500 plants, and requires $40 \mathrm{sq}$. ft. of ground.

Cucumber.......... oz. for 150 hills.

Cress................ $10 \mathrm{oz}$. sows a bed 16 feet square.

Figg Plant.......... 1 oz. gives 2,000 plants.

Endive...............

Leek............. oz. gives 2,000 plants, and requires 60 feet of ground.

Lettuce.......... oz. gives 7,000 plants, and requires a secd bed of 120 feet.

Melon.............. 1 oz. for 120 hills.

Nasturtium......... $1 \mathrm{oz}$. sows 25 feet of row.

Onion...............

Okra..............

Parsley..................

Parsnips............ $1 \mathrm{oz}$, sows 250 feet of row.

Peppers................. 10 ozives 2,500 plants.

Peas:.............

Pumpkin............... 1 oz. to 150 hills.

Radish............. $10 z$. to 100 feet.

Saisify .............

Spinach............ oz. to 200 feet of row.

Squash................. to 75 hills.

Tomato..............

Turnip.............. oz. to 2,000 feet

Watermelon........... $1 \mathrm{oz}$, to 50 hills.

\section{Quantities of Seed Required to the Acre}

\begin{tabular}{|c|c|}
\hline NAME & $\begin{array}{l}\text { QUANTITY } \\
\text { OF SEED }\end{array}$ \\
\hline $\begin{array}{l}\text { Wheat } \\
\text { Barley } \\
\text { Oats. } \\
\text { Rye.. } \\
\text { Buck } \\
\text { Millet. } \\
\text { Corn. } \\
\text { Beans. } \\
\text { Peas.. } \\
\text { Hemp. } \\
\text { Flax. } \\
\text { Rice. }\end{array}$ & 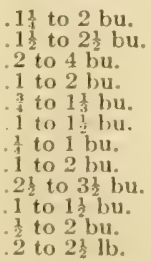 \\
\hline
\end{tabular}

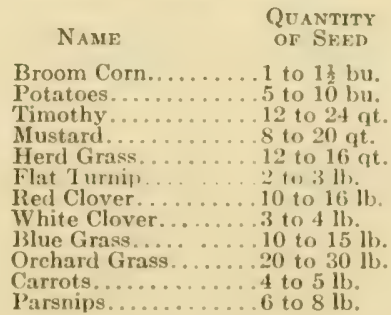




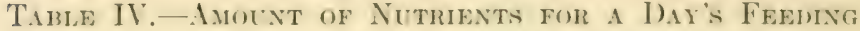

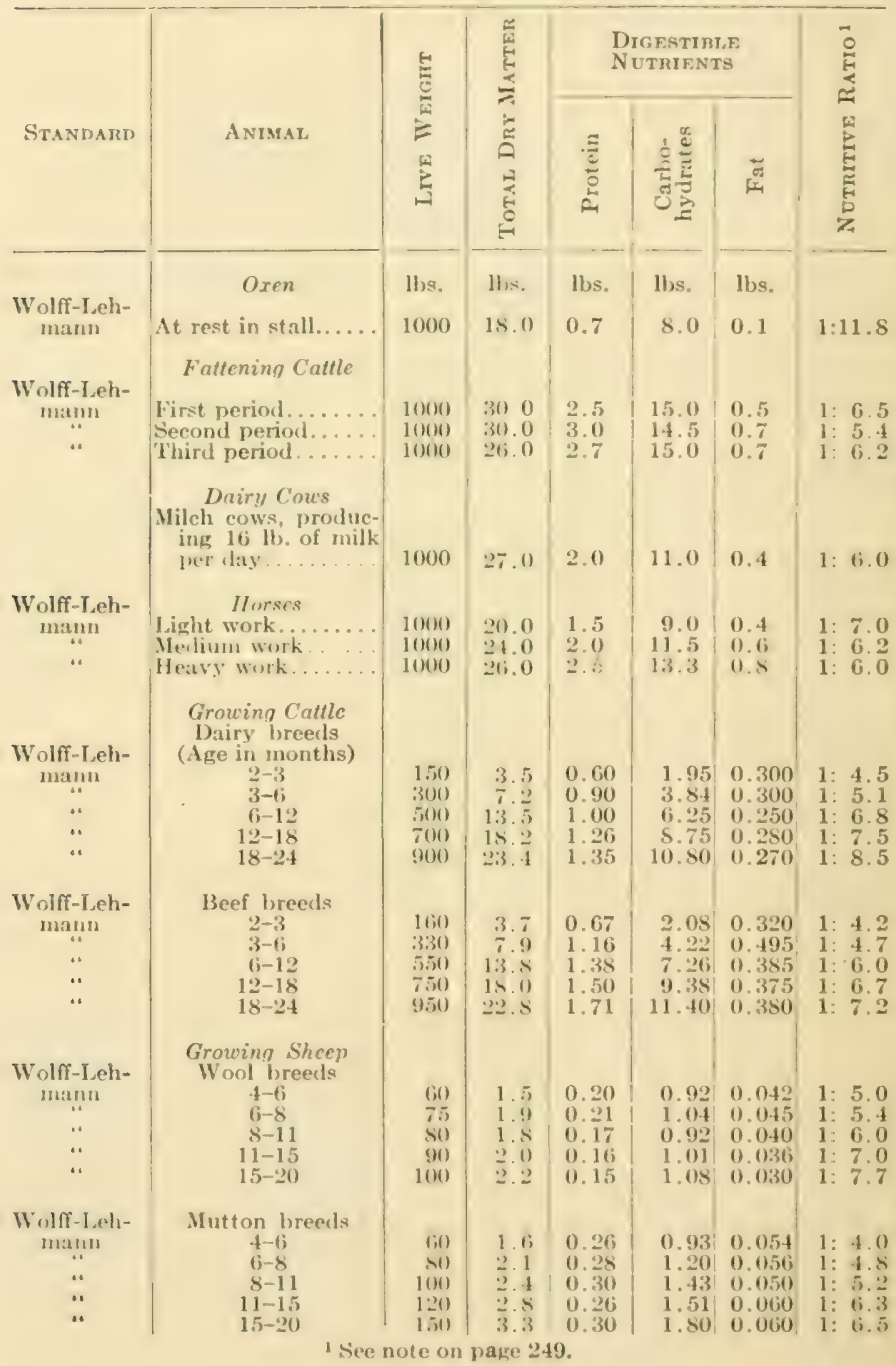




\section{TABLE IV.-Continued}

\begin{tabular}{|c|c|c|c|c|c|c|c|}
\hline \multirow[b]{2}{*}{ Standard } & \multirow[b]{2}{*}{ ANIMAL } & \multirow{2}{*}{ 惫 } & \multirow{2}{*}{ 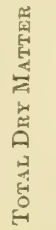 } & \multicolumn{3}{|c|}{$\begin{array}{l}\text { DrGESTIBLE } \\
\text { NuTRIENTS }\end{array}$} & \multirow{2}{*}{ } \\
\hline & & & & 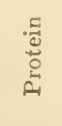 & 定离 & 崖 & \\
\hline of & $\begin{array}{l}\text { Growing Swine } \\
\text { Breeding stock } \\
\text { (Age in months) }\end{array}$ & lbs. & lbs. & lbs. & lbs. & lbs. & \\
\hline $\begin{array}{c}\text { mann } \\
\because . \\
\because . \\
.\end{array}$ & $\begin{array}{l}2-3 \\
3-5 \\
5-6 \\
6-8 \\
8-12\end{array}$ & $\begin{array}{r}50 \\
100 \\
120 \\
200 \\
250\end{array}$ & $\begin{array}{l}2.2 \\
3.5 \\
3.8 \\
5.6 \\
6.3\end{array}$ & $\begin{array}{l}0.38 \\
0.50 \\
0.44 \\
0.56 \\
0.53\end{array}$ & $\begin{array}{l}1.40 \\
2.31 \\
2.56 \\
3.74 \\
3.83\end{array}$ & $\begin{array}{l}0.050 \\
0.080 \\
0.048 \\
0.060 \\
0.050\end{array}$ & $\begin{array}{l}1: 4.0 \\
1: 5.0 \\
1: 6.0 \\
1: 7.0 \\
1: 7.5\end{array}$ \\
\hline $\begin{array}{l}\text { Wolff-Leh- } \\
\text { mann } \\
\because \\
\ldots \\
\because\end{array}$ & $\begin{array}{l}\text { Growing fattening } \\
\text { Swine } \\
\\
2-3 \\
3-5 \\
5-6 \\
6-8 \\
9-12\end{array}$ & $\begin{array}{r}50 \\
100 \\
150 \\
200 \\
200\end{array}$ & $\begin{array}{l}2.2 \\
3.5 \\
5.0 \\
6.0 \\
5.2\end{array}$ & $\begin{array}{l}0.38 \\
0.50 \\
0.65 \\
0.72 \\
0.60\end{array}$ & $\begin{array}{l}1.40 \\
2.31 \\
3.35 \\
4.10 \\
3.66\end{array}$ & $\begin{array}{l}0.050 \\
0.080 \\
0.090 \\
0.080 \\
0.060\end{array}$ & $\begin{array}{l}1: 4.0 \\
1: 5.0 \\
1: 5.5 \\
1: 6.0 \\
1: 6.4\end{array}$ \\
\hline & Human beings & & & $\begin{array}{l}\text { Pro- } \\
\text { tein }\end{array}$ & $\begin{array}{c}\text { Car- } \\
\text { bohy- } \\
\text { drates } \\
\text { and } \\
\text { Fats }\end{array}$ & & \\
\hline & $\begin{array}{c}\text { Children, 6-15 yrs. } \\
\text { Students } \\
\text { Professional Men } \\
\text { Man with moderate } \\
\text { work } \\
\text { Man with hard work }\end{array}$ & & & $\begin{array}{l}0.16 \\
0.20 \\
0.27 \\
0.28 \\
0.39\end{array}$ & $\begin{array}{l}0.93 \\
1.11 \\
1.76 \\
1.62 \\
2.67\end{array}$ & & $\begin{array}{l}1: 5.2 \\
1: 5.5 \\
1: 4.7 \\
1: 5.8 \\
1: 6.9\end{array}$ \\
\hline
\end{tabular}

1 The nutritive ratio is obtained by multiplying the number of pounds of fat by 2 !, adding the product to the number of pounds of carbohydrates, and dividing this sum by the number of pounds of protein for the second term of the ratio. The first term of the ratio is 1 . 


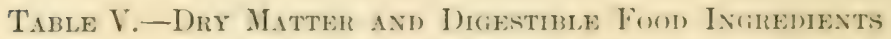
in 100 Pounds of Fendng Stuffs ${ }^{1}$

\begin{tabular}{|c|c|c|c|c|c|}
\hline FEEIR: STUFF & $\begin{array}{c}\text { Totar, } \\
\text { DRY } \\
\text { МАTTER }\end{array}$ & P'IRTTIN & 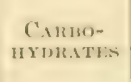 & Fit & $\begin{array}{l}\text { Fit.1 } \\
\text { Vin:1: }\end{array}$ \\
\hline $\begin{array}{l}\text { Green fodder: } \\
\text { Corn fodiler }{ }^{2} \text { (average of }\end{array}$ & Pounds & Pounds & Pounds & Pounds & Calories \\
\hline Kafir-com fodder......... & 20.7 & 1.10 & 12.08 & 0.37 & 26,076 \\
\hline $\begin{array}{l}\text { Kafir-coin fodder........ } \\
\text { Rye fodder. }\end{array}$ & 27.0 & 0.87 & 13.80 & 0.43 & 29,101 \\
\hline Rye fodder. . & 23.4 & 2.05 & 14.11 & 0.44 & 31,914 \\
\hline $\begin{array}{l}\text { Oat fodeler } \\
\text { Redtop in bloom. }\end{array}$ & 37.8 & 2.44 & 17.99 & & $\begin{array}{l}42,093 \\
45\end{array}$ \\
\hline & 34.7 & 2.06 & 21.24 & 0.58 & 45,785 \\
\hline $\begin{array}{l}\text { Orchard grass, in bloom. } \\
\text { Meadow fescue, in bloom. }\end{array}$ & 27.0 & 1.91 & 15.91 & 0.58 & 35,593 \\
\hline & & & & & 35,755 \\
\hline $\begin{array}{l}\text { stages. } \\
\text { Kentucky blue grass...... }\end{array}$ & $\begin{array}{l}38.4 \\
3.4 .9\end{array}$ & 2.01 & $21 \cdot 22$ & 0.64 & 45,909 \\
\hline Kentucky blue grass.... & $\begin{array}{l}34.9 \\
28.9\end{array}$ & $\begin{array}{l}2.66 \\
1.92\end{array}$ & $\begin{array}{l}17.78 \\
15.63\end{array}$ & & $\begin{array}{l}40,930 \\
34,162\end{array}$ \\
\hline $\begin{array}{l}\text { Red clover, at different } \\
\text { stages............... }\end{array}$ & & & & & $3+, 162$ \\
\hline $\begin{array}{l}\text { Crimson clover } \\
\text { Alfalfa, }{ }^{4} \text { at different }\end{array}$ & $\begin{array}{l}29.2 \\
19.3\end{array}$ & $\begin{array}{l}3.07 \\
2.16\end{array}$ & $\begin{array}{r}14.82 \\
9.31\end{array}$ & $\begin{array}{l}0.69 \\
0.44\end{array}$ & $\begin{array}{l}36,187 \\
23,191\end{array}$ \\
\hline 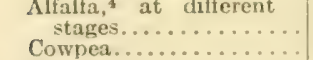 & 28.2 & & 11.20 & - & (2) \\
\hline $\begin{array}{l}\text { Cowpea.............. } \\
\text { Soy bean...... }\end{array}$ & 16.4 & 1.68 & 8.08 & 5 & 19,209 \\
\hline $\begin{array}{l}\text { Soy b } \\
\text { Rape }\end{array}$ & 28.5 & 2.79 & 11.82 & & 29,833 \\
\hline $\begin{array}{l}\text { Rape } \\
\text { Corn sil: }\end{array}$ & 14.3 & 2.16 & 8.65 & 2 & 21,457 \\
\hline $\begin{array}{l}\text { Corn silage (recent analy-es) } \\
\text { Corn fodder, }{ }^{2} \text { field cured... }\end{array}$ & 25.6 & 1.21 & 14.56 & 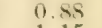 & 33.046 \\
\hline $\begin{array}{l}\text { Corn fodder, }{ }^{2} \text { field cured... . } \\
\text { Corn stover, field cured..... }\end{array}$ & 57.8 & 2.34 & 32.34 & 1.15 & 69,358 \\
\hline $\begin{array}{l}\text { Corn stover, field cured... } \\
\text { Kafir-corn stover, field }\end{array}$ & 59.5 & 1.98 & 33.16 & 0.57 & 67,766 \\
\hline Kafir-corn stover, field & 80.8 & 1.82 & 41.42 & 0.98 & 84,562 \\
\hline $\begin{array}{l}\text { Hay from: } \\
\text { Barley.. }\end{array}$ & S & & & & \\
\hline $\begin{array}{l}\text { Barley..... } \\
\text { Onts..... }\end{array}$ & 8 & 4. & $\begin{array}{l}35.94 \\
33.35\end{array}$ & $\frac{5}{7}$ & $\begin{array}{l}82,894 \\
76,649\end{array}$ \\
\hline Orehard gras & 90. & -1. & 41.9 & & 92 \\
\hline Red & 91.1 & 4.8 & 46.83 & 0.95 & 100,078 \\
\hline 3 (all analyoes). & $56 \mathrm{~s}$ & 2.8 & 43.72 & 1. 13 & 92.729 \\
\hline Kentucky blue grass... & 78.8 & 4.76 & 37.46 & 1.99 & 86,927 \\
\hline Ifur & 92.3 & 4.50 & 51.67 & 1.34 & 110,131 \\
\hline Mea & 81.0 & 4.20 & 43.34 & 1.73 & 95,725 \\
\hline Mix & 87.1 & 4.22 & 43.26 & 1.33 & 93,925 \\
\hline $\mathrm{Ro}$ & 83.4 & 7.19 & 41.20 & 1.43 & 96,040 \\
\hline Mixed grasses and clover & 87.1 & 6.16 & 42.71 & 1.46 & 97,059 \\
\hline$\ldots \ldots \ldots \ldots$ & 84.7 & 7.38 & 38.15 & 1.81 & 92,324 \\
\hline Alsike cl & 90 & \$. 1 & 41.70 & 1. 36 & 98,460 \\
\hline Whi & 90. & 11.46 & +1.82 & 1.48 & 105,346 \\
\hline ver.. & 91.4 & 10.4 & 38.13 & 1.29 & 95,877 \\
\hline Alfalfa ${ }^{4}$. & 91.6 & 10.5 & 37.33 & 1.38 & 94,936 \\
\hline & 89. & 10.79 & 38.40 & 1.51 & 97,865 \\
\hline & 88.7 & 10.78 & 38.72 & 1.54 & 98,569 \\
\hline Wheatstraw. & 90.4 & 0.37 & 36.30 & 0.40 & 69,894 \\
\hline Ryestraw... & 92. & 0.6 & 40.58 & 0.38 & 78,251 \\
\hline Oat $s$ & 90.8 & 1.2 & 38.64 & 0.76 & 77,310 \\
\hline oy-bean stra & 89.9 & 2.30 & 39.98 & 1.03 & 82,987 \\
\hline
\end{tabular}

1 From Farmers' Bullatin No. 22 [Revised Edition].

${ }^{2}$ Corn fodder is entire plant, usually sown thick.

${ }^{3}$ Herd's grass of New England and New York.

i Lucern. 
Table V.-Continued

\begin{tabular}{|c|c|c|c|c|c|}
\hline FrediNG STUFF & $\begin{array}{c}\text { Total } \\
\text { DRY } \\
\text { MATTER }\end{array}$ & Protein & $\begin{array}{l}\text { CAnbo- } \\
\text { IrYmates }\end{array}$ & Fat & $\begin{array}{l}\text { Fuel } \\
\text { VALUE }\end{array}$ \\
\hline Roots and tubers: & Pounds & Pounds & Pounds & Pounds & Calories \\
\hline Potatoes... & 21.1 & 1.36 & 16.43 & & 33,089 \\
\hline Beets. & 13.0 & 1.21 & 8.84 & 0.05 & 18,904 \\
\hline Mangel-wurzels. & 9.1 & 1.03 & 5.65 & 0.11 & 12,889 \\
\hline Turnips. & 9.5 & 0.81 & 6.46 & 0.11 & 13,986 \\
\hline Ruta-bag: & 11.4 & 0.88 & 7.74 & 0.11 & 16,497 \\
\hline Carrots.. & 11.4 & 0.81 & 7.83 & 0.22 & 16,999 \\
\hline $\begin{array}{l}\text { Grains and other seeds: } \\
\text { Corn (average of dent }\end{array}$ & & & & & \\
\hline and flint)............ & 81.1 & 7.14 & 66.12 & 4.97 & 157,237 \\
\hline Kafir corn... & 87.5 & 5.78 & & 1.33 & 116,02 \\
\hline Barley.. & 89.1 & 8.69 & 64.83 & 1.60 & 143,499 \\
\hline Oats... & 89.0 & 9.25 & 48.34 & 4.18 & 124,757 \\
\hline Rye.. & 88.4 & 9.12 & 3 & 1.36 & 152,400 \\
\hline Wheat (all varietie & 89.5 & 10.23 & 69.21 & 1.68 & 154,848 \\
\hline Cotton seed ( & 89.7 & 11.08 & 33.13 & 18.44 & 160,047 \\
\hline Mill products: & & & & & \\
\hline Corn meal. . ...... & 85.0 & 6.26 & 65.26 & 3.50 & 147,797 \\
\hline Corn-and-cob meal. & 84.9 & 4.76 & 6 & 2.94 & 132,972 \\
\hline Oatn & 92.1 & 11.53 & 06 & 5.93 & 143,302 \\
\hline Barley meal...... & 58.1 & .36 & 62.88 & 1.96 & 138,918 \\
\hline $\begin{array}{l}\text { Ground corn and oats, } \\
\text { equal parts............ }\end{array}$ & 88.1 & 7.01 & 61.20 & 3.87 & 143,202 \\
\hline Pea meal. . . . . . . . . . & 89.5 & 16.77 & 51.78 & 0.65 & 130,240 \\
\hline Waste products: & & & & & \\
\hline $\begin{array}{l}\text { Giuten n } \\
\text { Buffal }\end{array}$ & 91.8 & 21.56 & 43.02 & 11.87 & 170,210 \\
\hline Chic & & 9 & & 4.75 & 155,918 \\
\hline Hammond & 9 & 24.90 & 45.72 & 10.16 & 174,228 \\
\hline King................. & 92.8 & 30.10 & 35.10 & 15.67 & 187,399 \\
\hline 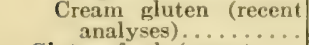 & 90.4 & 30.45 & 45.36 & 2.47 & 151,420 \\
\hline Gluten feed (recent & 91.9 & 19.95 & 54.22 & 5.35 & 160.533 \\
\hline Buffalo (recent analy- & & & 34.22 & 3.30 & 100,030 \\
\hline ses & 91.0 & 22.88 & 51 & 2.89 & 150,933 \\
\hline Rockfori & & & & 3.82 & 15 \\
\hline Homi & & 3 & 61 & 7.06 & 15 \\
\hline Malt & & & 43 & & 120,624 \\
\hline Brewers' g & 24.3 & 4.00 & 9. & 1.38 & 30,692 \\
\hline Brewers' gr & 92.0 & 19.04 & 31.79 & 6.03 & 119,990 \\
\hline $\begin{array}{l}\text { Distillery grains (dried), } \\
\text { principally corn....... }\end{array}$ & 93.0 & 21.93 & 38.09 & 10.83 & 157,340 \\
\hline Distillery grains (dried), & & & & & \\
\hline $\begin{array}{l}\text { principally rye... } \\
\text { Atlas gluten feed (dis- }\end{array}$ & 93 & 10.38 & 42. & 6.38 & 125,243 \\
\hline$y$-product). & 92.6 & 23.23 & 35.6 .4 & 11.88 & 159.818 \\
\hline Rye & & 77 & & 1.79 & 126,352 \\
\hline alyses. & 88.5 & 2.01 & & & 111,138 \\
\hline Wheat midrillin & 84.0 & t & 53.15 & 3.40 & 136.996 \\
\hline & & & & 3.83 & 131,855 \\
\hline Buc & 88.5 & 19.29 & 31.65 & 4.56 & 113,992 \\
\hline Buc & 88. & 22.34 & & 6.21 & 134,979 \\
\hline Cotto & 92.0 & 9.65 & 38 & 3.37 & 103,911 \\
\hline Cott & 91. & 37.01 & & 12.58 & 152,653 \\
\hline Cotto & 88 & 1.05 & 32.21 & 1.89 & 69,839 \\
\hline Linseed meal (uld process) & 90.8 & 25.76 & 32.81 & 7.06 & 141,313 \\
\hline
\end{tabular}


TABLE V.-Continued

\begin{tabular}{|c|c|c|c|c|c|}
\hline Fininis StefF & $\begin{array}{l}\text { TotaL } \\
\text { I)Y } \\
\text { M.Tт:K }\end{array}$ & P'mтікік & 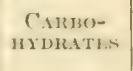 & Fit & $\begin{array}{l}\text { FuniL } \\
\text { VaLUe }\end{array}$ \\
\hline $\begin{array}{l}\text { Waste products (cont'd): } \\
\text { Linseed meal (new proc- }\end{array}$ & Pounds & Pounds & Pounds & Younds & Calorics \\
\hline ess).................... & 90.1 & 30.59 & 38.72 & 2.90 & 141,155 \\
\hline $\begin{array}{l}\text { Sugar-beet pulp (fresh).. } \\
\text { Sugar-beet pulp (dry)... }\end{array}$ & $\begin{array}{l}10.1 \\
93.6\end{array}$ & $\begin{array}{l}0.63 \\
6.80\end{array}$ & $\begin{array}{r}7.12 \\
65.49\end{array}$ & $\ldots$ & $\begin{array}{r}14,415 \\
134,459\end{array}$ \\
\hline Milk and its by-products: & & & & & \\
\hline $\begin{array}{l}\text { Whole milk............. } \\
\text { Skim milk, cream raised }\end{array}$ & 12.8 & 3.38 & 4.80 & 3.70 & 30,829 \\
\hline $\begin{array}{l}\text { by setting............. } \\
\text { Skim milk, creain raised }\end{array}$ & 9.6 & 3.10 & 4.61 & 0.90 & 18,139 \\
\hline by separator.......... & 9.4 & 3.01 & 5.10 & 0.30 & 16,351 \\
\hline Buttermilk........... & 9. & & & 0.50 & 16,097 \\
\hline Whey. & 6.2 & 0.56 & 5.00 & 0.10 & 10,764 \\
\hline
\end{tabular}

\section{Fuei Value}

The last eolumn in the above table, hearled "fuel value," indieates the heat and energy power of the food. As stated ahove, one of the primary functions of the food is to produce heat for the borly and enerery for work. The value of food for this purpose is measured in "hest units" or " "alories," "and is calculated from the nutrients digested. Thus the fuel power of 1 pound of digestible fat is estimated to be 4,220 catlories, and of 1 pound of digestible portein or eartohy drates about 1, \$ 60 calories. The total fucl value of a feeding stuff is found by using these factors.

The meaning of the figures in the above table is that in 100 pounds of green eorn fodder containing an average amount of dry matter (20.7 pounds) there are contained approximately 1.10 pounds of digestible protein (materials containing nit rogen), 12.08 pounds of digestible carbohylrates (stareh, sugar, fiber, etc.), and 0.37 pound of digestible fat ; and that these materials when consumed in the body will yiede 26,076 calories of heat, furnishing energy for work and maintaining the temperature of the body.

1 A calorie of heat is the amount repuired to ratise the temperature of a pound of water about $4^{\circ} \mathrm{l}^{r}$. 


\section{Table VI.-Rations Actually Fed to Horses and Digestible Nutrients AND ENERGY IN RATIONS}

(Calculated on basis of 1,000 pounds live weight)

\section{KIND OF HOILES}

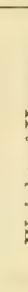

Army Horsts

United States:

Cavalry...........

Artillery..........

Mules.

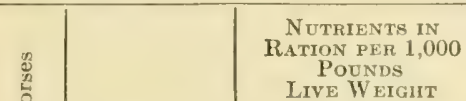

Digestible Nutri-

LIVE WEIGHT

\section{Horses with Light Work}

Driving horse. Wyoming Station.

Carriage horse

Average.

Iire company horses:

Boston, Mass.....

Chicago, III.

Average of 6, including above .

\section{L.bs,}

1,050

1,125

Rations

0
0
0
0
0

Actually Fed

\section{1,025}

Hats, $12 \ldots$.

Oats, 12

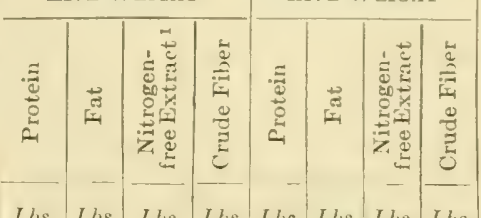
ENTS IN RATION LIVE WEIGHT

Oats, $9 \ldots$

Lus. Lbs. Lbs. Lbs. Ihs. Lls. Lbs. Lhs.

$2.1+0.9012 .82+.951 .250 .578 .001 .9723,300$

$\{2.00, .8411 .96+.621 .16 \mid .537 .481 .8421,750$

Hay, 14.... 1.84 .7811 .394 .801 .00 .486 .851 .94

20,250

1,200 SAlfalfa, 21.25.

Straw, 3.2.

1,050

Oats, $10 \ldots$

(Hay, 12....

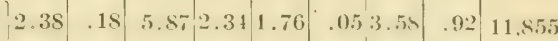

\begin{tabular}{l|l|l|l|l|l|l|l|l}
2.06 & .76 & 10.42 & 3.87 & 1.40 & .406 .97 & 1.44 & 19.935
\end{tabular}

\begin{tabular}{l|l|l|l|l|l|l|l|l|}
2.22 & .47 & 8.15 & 3.10 & 1.58 & 2.5 .27 & 1.18 & 15.895
\end{tabular}

$1,400\left|\begin{array}{l}\text { Ground grain, } \\ 9.38 \\ \text { Hay, is . . . . }\end{array}\right|$

\begin{tabular}{llll|l|l|l|l|l}
1.65 & .68 & 9.57 & 4.57 & .87 & .41 & 6.14 & 1.73 & 18,000
\end{tabular}

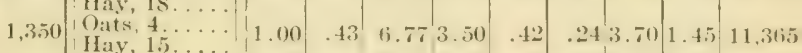

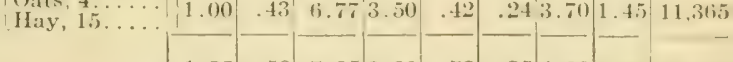

General average for light work.

\section{Horses with Moderate} IVork:

Express horses:

Kinhmond, Va., summer.

.

.

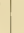

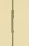

Jersey City, N. J...

Boston, Mass.

Averace of 4, including alove.

1,325

1,325

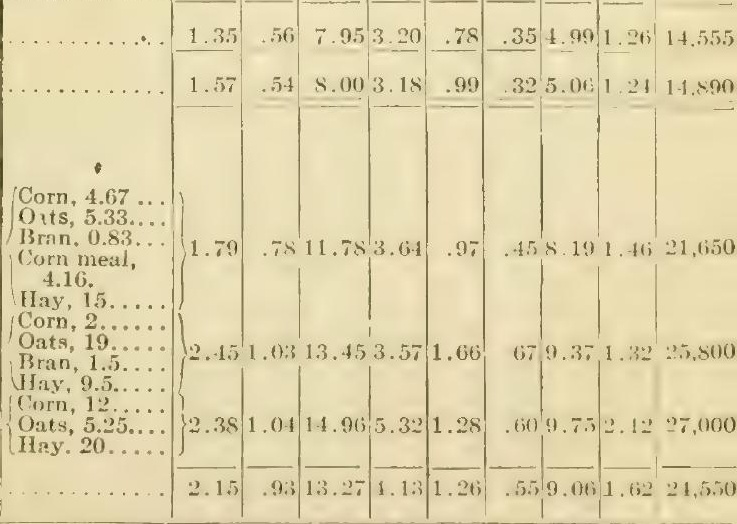

Corn, $4.67 \ldots$

Oits, 5.33...

Corn meal.

1 Nitrogen-frec extract consists of the carbohydrates minus the crude fiber, i.e. engar, starch, and gum, 


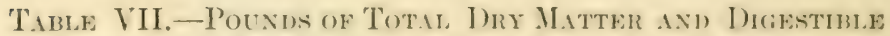

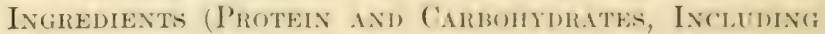
Fats $\times 2.25)$ an Varye Weights of Fonders and Fends.

(T-ed by courtesy of P'rofeswor J. L. Hills, of the Vermont Lixperiment Station, modified from Bulletin 81.)

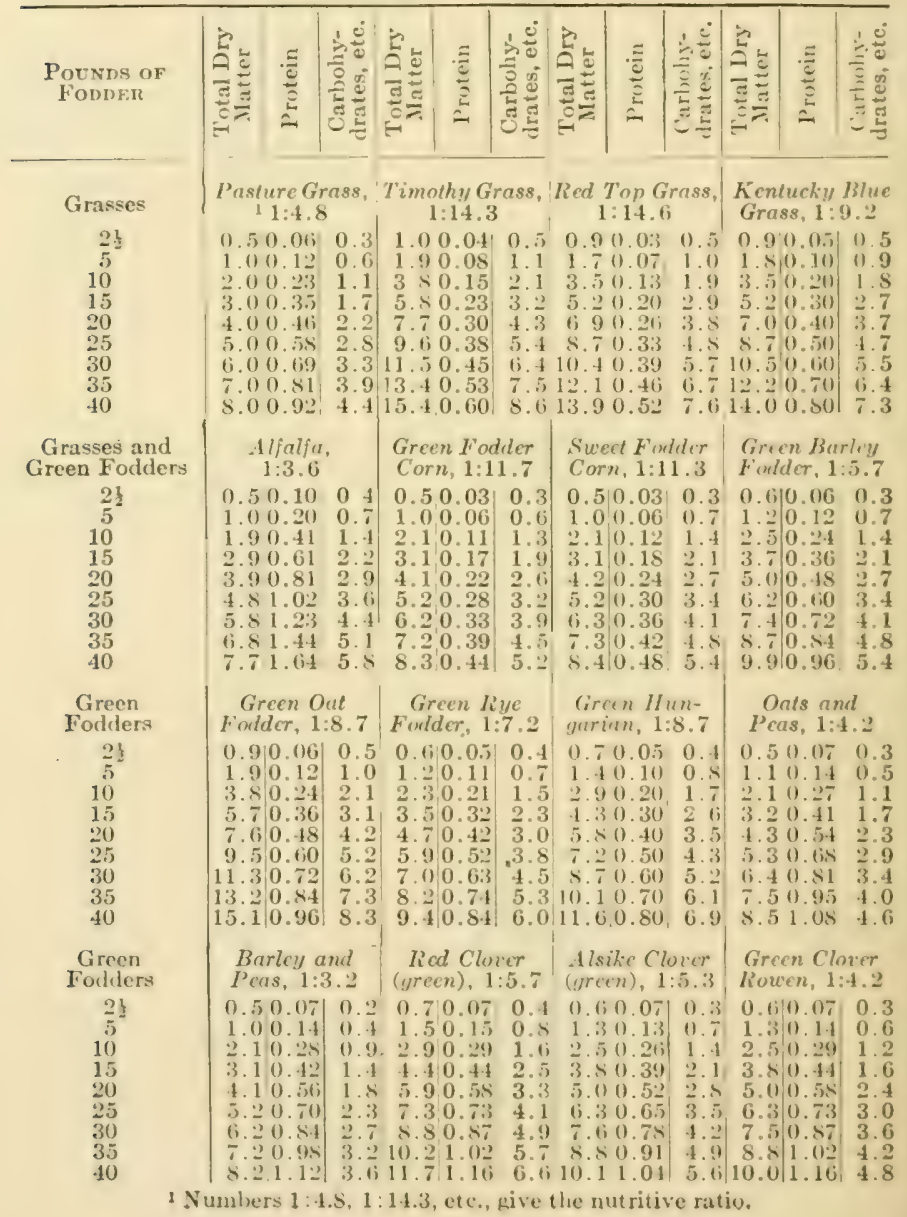


Table VII.-Continued

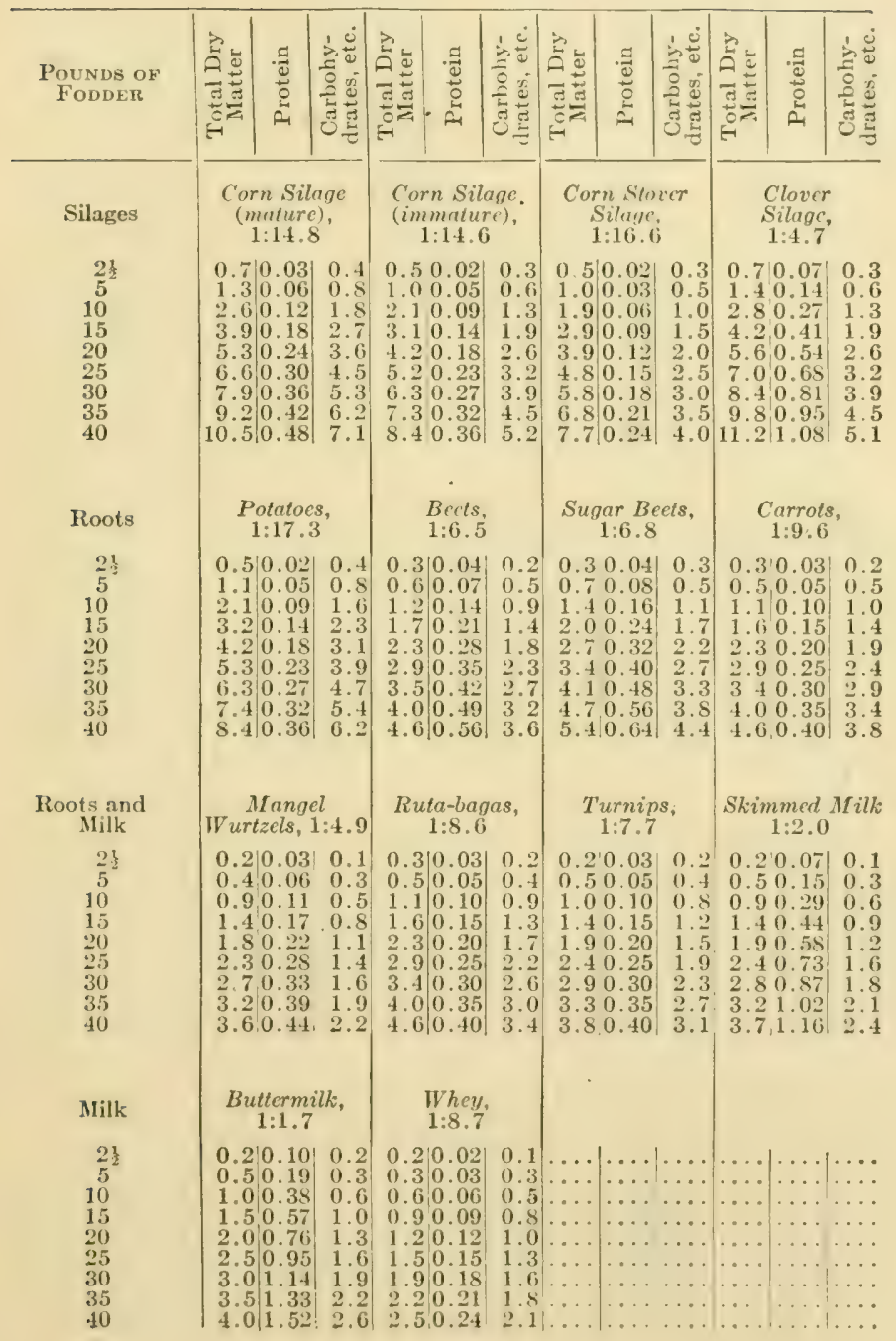




\section{'Table VII.--Continued}

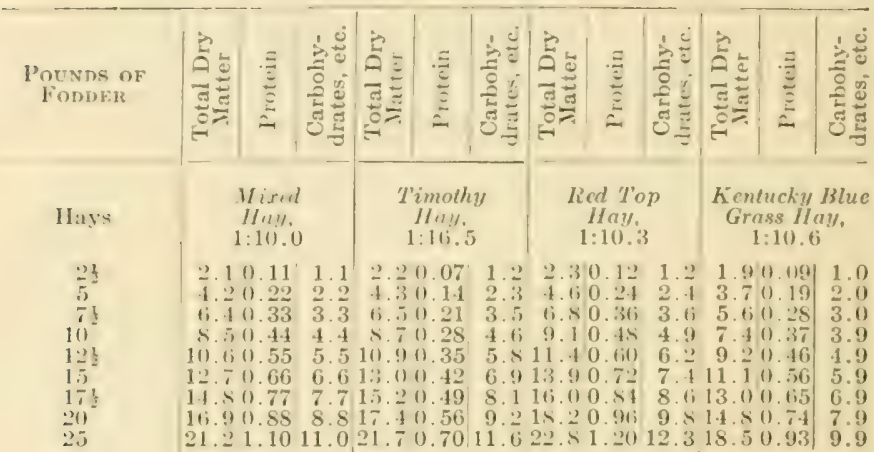

Hays and

Dry-Fodder

$$
\begin{gathered}
23 \\
5 \\
73 \\
10 \\
124 \\
15 \\
175 \\
211^{2} \\
25
\end{gathered}
$$

Dry Fodilers and Hays

$2 \frac{1}{5}$
$\frac{21}{2}$
10
$12 \frac{2}{2}$
15
$17 \frac{1}{2}$
20
25
Hays and
Straw
25
5
75
10
$12 \frac{1}{2}$
15
17
20
25




\section{TABLE VII.-Continued}

\begin{tabular}{|c|c|c|c|c|c|c|c|c|c|c|c|c|}
\hline $\begin{array}{l}\text { Pounds of } \\
\text { FoDDER }\end{array}$ & 至 & 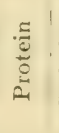 & 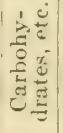 & 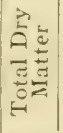 & $\frac{5}{\frac{\pi}{2}}$ & 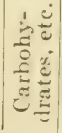 & 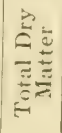 & 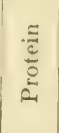 & 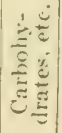 & 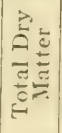 & $\frac{a}{\frac{a}{2}}$ & 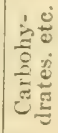 \\
\hline Straws & \multicolumn{3}{|c|}{$\begin{array}{c}\text { Oat Straw, } \\
1: 38.3\end{array}$} & \multicolumn{3}{|c|}{$\begin{array}{c}\text { Wheat Straw, } \\
1: 93.0\end{array}$} & \multicolumn{3}{|c|}{$\begin{array}{c}\text { Rye Straw } \\
1: 69.0\end{array}$} & & & \\
\hline $\begin{array}{c}2 \frac{1}{2} \\
5 \\
7 \frac{1}{2} \\
10 \\
12 \frac{1}{2} \\
15 \\
17 \frac{1}{2} \\
20^{2} \\
25\end{array}$ & $\begin{array}{r}2.3 \\
4.6 \\
6.8 \\
9.1 \\
11.4 \\
13.9 \\
16.0 \\
18.2 \\
22.7\end{array}$ & $\begin{array}{l}.03 \\
.06 \\
.09 \\
.12 \\
.15 \\
.15 \\
.21 \\
.24 \\
.30\end{array}$ & \begin{tabular}{|r|}
1.2 \\
2.3 \\
3.5 \\
4.6 \\
5.8 \\
6.9 \\
8.1 \\
9.2 \\
11.5
\end{tabular} & $\begin{array}{r}2.3 \\
4.5 \\
6.8 \\
9.0 \\
11.3 \\
13.5 \\
15.8 \\
18.1 \\
22.6\end{array}$ & $\begin{array}{l}0.01 \\
.02 \\
.03 \\
.04 \\
.05 \\
.06 \\
.07 \\
.08 \\
.10\end{array}$ & $\begin{array}{l}0.9 \\
1.9 \\
2.8 \\
3.7 \\
4.6 \\
5.6 \\
6.5 \\
7.4 \\
9.3\end{array}$ & $\begin{array}{r}2.3 \\
4.6 \\
7.0 \\
9.3 \\
11.6 \\
13.9 \\
16.3 \\
18.6 \\
223.2\end{array}$ & $\begin{array}{l}0.02 \\
0.03 \\
0.05 \\
0.06 \\
0.05 \\
0.09 \\
0.11 \\
0.12 \\
0.15\end{array}$ & $\begin{array}{r}1.0 \\
2.1 \\
3.1 \\
4.1 \\
5.2 \\
6.2 \\
7.2 \\
8.3 \\
10.4\end{array}$ & & & \\
\hline Grains & $\begin{array}{r}\text { Cor } \\
1\end{array}$ & $\begin{array}{l}11 \mathrm{ce} \\
11.3\end{array}$ & al, & $\begin{array}{l}\text { Corn } \\
\text { Ifeat }\end{array}$ & $\begin{array}{c}-a n d- \\
l, 1: 1\end{array}$ & $\begin{array}{l}\mathrm{Col} \\
13.9\end{array}$ & & $\begin{array}{l}\text { Oats, } \\
1: t i .2\end{array}$ & & & $\begin{array}{l}\text { orend } \\
\text { ). } 1: 8\end{array}$ & $\begin{array}{l}\text { ler } \\
8.4\end{array}$ \\
\hline $\begin{array}{c}1^{\frac{1}{3}} \\
1^{\frac{1}{3}} \\
2 \\
3 \\
4 \\
5 \\
7 \frac{1}{2} \\
10^{\frac{1}{2}}\end{array}$ & $\begin{array}{l}0.2 \\
0.4 \\
0.9 \\
1.7 \\
2.6 \\
3.4 \\
4.3 \\
6.4 \\
8.5\end{array}$ & $\begin{array}{l}.02 \\
.03 \\
.06 \\
.13 \\
.19 \\
.25 \\
.32 \\
.45 \\
63\end{array}$ & $\begin{array}{l}0.2 \\
0.4 \\
0.7 \\
1.4 \\
2.1 \\
2.9 \\
3.6 \\
5.4 \\
7.1\end{array}$ & $\begin{array}{l}0.2 \\
0.4 \\
0.9 \\
1.7 \\
2.6 \\
3.4 \\
1.3 \\
6.4 \\
8.5\end{array}$ & $\begin{array}{l}.01 \\
.02 \\
.05 \\
.10 \\
.14 \\
.19 \\
.24 \\
.36 \\
.45\end{array}$ & $\begin{array}{l}0.2 \\
0.3 \\
0.7 \\
1.3 \\
2.0 \\
2.7 \\
3.4 \\
5.1 \\
6.7\end{array}$ & $\begin{array}{l}0.2 \\
0.4 \\
0.9 \\
1.8 \\
2.7 \\
3.6 \\
4.5 \\
6.7 \\
8.9\end{array}$ & $\begin{array}{l}0.02 \\
0.05 \\
0.09 \\
0.18 \\
0.28 \\
0.37 \\
0.46 \\
0.69 \\
0.92\end{array}$ & $\begin{array}{l}0.1 \\
0.3 \\
0.6 \\
1.1 \\
1.7 \\
2.3 \\
2.8 \\
4.3 \\
5.7\end{array}$ & $\begin{array}{l}0.2 \\
0.4 \\
0.9 \\
1.7 \\
2.6 \\
3.5 \\
4.4 \\
6.5 \\
8.7\end{array}$ & $\begin{array}{l}0.02 \\
0.04 \\
0.08 \\
0.15 \\
0.23 \\
0.31 \\
0.39 \\
0.58 \\
0.78\end{array}$ & \begin{tabular}{|l}
0.2 \\
0.3 \\
0.6 \\
1.3 \\
1.9 \\
2.6 \\
3.2 \\
4.9 \\
6.5
\end{tabular} \\
\hline $\begin{array}{l}\text { Grains and } \\
\text { By-products }\end{array}$ & $\begin{array}{l}\text { Prov } \\
\text { suld } \\
\text { En }\end{array}$ & $\begin{array}{l}\text { nder } \\
\text { in N } \\
\text { olund } \\
: 9.4\end{array}$ & $\begin{array}{l}\text { (uss } \\
\text { li) } \\
\text { i) }\end{array}$ & $\begin{array}{c}O a t \\
1\end{array}$ & $\begin{array}{l}\text { IIull } \\
1 \mathrm{~s} .2\end{array}$ & & Quak & $\begin{array}{l}\text { ar } D \\
\text { Fend } \\
1: 4.6\end{array}$ & airy & H. & $\begin{array}{l}0.7) \\
F, 1 \\
1: 3.3\end{array}$ & ziry \\
\hline $\begin{array}{c}1^{\frac{1}{1}} \\
1^{\frac{1}{2}} \\
2 \\
3 \\
4 \\
5 \\
7 \frac{1}{2} \\
10^{\frac{1}{7}}\end{array}$ & $\begin{array}{l}0.2 \\
0.4 \\
0.9 \\
1.8 \\
2.7 \\
3.5 \\
4.4 \\
15.6 \\
8.8\end{array}$ & $\begin{array}{l}.02 \\
.03 \\
.07 \\
.14 \\
.20 \\
.27 \\
.34 \\
.51 \\
.68\end{array}$ & $\begin{array}{l}0.2 \\
0.3 \\
0.6 \\
1.3 \\
1.9 \\
2.5 \\
3.2 \\
4.5 \\
6.4\end{array}$ & $\begin{array}{l}0.2 \\
0.5 \\
0.9 \\
1.9 \\
2.8 \\
3.7 \\
4.6 \\
7.0 \\
9.3\end{array}$ & $\begin{array}{l}.01 \\
.02 \\
.03 \\
.05 \\
.05 \\
.10 \\
.13 \\
.20 \\
.26\end{array}$ & $\begin{array}{l}0.1 \\
0.3 \\
0.5 \\
0.9 \\
1.4 \\
1.4 \\
2.4 \\
3.5 \\
4.7\end{array}$ & $\begin{array}{l}0.2 \\
0.5 \\
0.9 \\
1.8 \\
2.8 \\
3.7 \\
4.6 \\
6.9 \\
9.2\end{array}$ & $\begin{array}{l}0.03 \\
0.05 \\
0.11 \\
0.22 \\
0.23 \\
0.44 \\
0.55 \\
0.85 \\
1.09\end{array}$ & \begin{tabular}{l}
0.1 \\
0.3 \\
0.5 \\
1.0 \\
1.5 \\
\hdashline .0 \\
2.5 \\
3.5 \\
5.0
\end{tabular} & $\begin{array}{l}0.21 \\
0.51 \\
0.9 \\
1.8 \\
2.7 \\
3.6 \\
4.6 \\
6.8 \\
9.1\end{array}$ & $\begin{array}{l}0.04 \\
0.07 \\
0.15 \\
0.29 \\
0.44 \\
0.59 \\
0.74 \\
1.10 \\
1.47\end{array}$ & $\begin{array}{l}0.1 \\
0.2 \\
0.5 \\
1.0 \\
1.5 \\
2.0 \\
2.5 \\
3.7 \\
1.9\end{array}$ \\
\hline $\begin{array}{l}\text { By-products, } \\
\text { etc. }\end{array}$ & $\begin{array}{l}\text { Tict } \\
\text { and ( } \\
1\end{array}$ & $\begin{array}{l}\text { Cor } \\
t F e \\
1.1\end{array}$ & eed, & H. 0 & $\begin{array}{c}\text { IIor } \\
: 6.4\end{array}$ & & & $\begin{array}{l}\text { arley, } \\
: S .0\end{array}$ & & $\begin{array}{r}I 3 \\
\text { Sire } \\
1\end{array}$ & $\begin{array}{l}\text { 3arley } \\
\text { exnin! } \\
1: 7.7\end{array}$ & \\
\hline $\begin{array}{c}1^{\frac{1}{3}} \\
1^{\frac{1}{2}} \\
2 \\
3 \\
4 \\
5 \\
7 \frac{1}{2} \\
10^{\frac{1}{2}}\end{array}$ & $\begin{array}{l}0.2 \\
0.5 \\
0.9 \\
1.8 \\
2.7 \\
3.6 \\
4.5 \\
6.5 \\
9.0\end{array}$ & $\begin{array}{l}02 \\
0.3 \\
06 \\
13 \\
19 \\
25 \\
332 \\
.17 \\
63\end{array}$ & $\begin{array}{l}0.2 \\
0.3 \\
0.6 \\
1.3 \\
1.9 \\
2.5 \\
3.2 \\
4.5 \\
6.4\end{array}$ & $\begin{array}{l}0.22 \\
0.51 \\
0.91 \\
1.81 \\
2.7 \\
3.41 \\
4.51 \\
6.8 \\
9.0\end{array}$ & $\begin{array}{l}.102 \\
.05 \\
.09 \\
.18 \\
.28 \\
.37 \\
.41 \\
.69 \\
.92\end{array}$ & $\begin{array}{l}0.1 \\
0.3 \\
0.4 \\
1.2 \\
1.5 \\
2.4 \\
2.4 \\
4.4 \\
5.9\end{array}$ & $\begin{array}{l}0.2 \\
0.4 \\
0.9 \\
1.2 \\
2.7 \\
3.4 \\
4.5 \\
6.7 \\
8.9\end{array}$ & $\begin{array}{l}0.02 \\
0.04 \\
0.09 \\
0.17 \\
0.26 \\
0.33 \\
0.41 \\
0.41 \\
0.85 \\
0.87\end{array}$ & $\begin{array}{l}0.2 \\
0.3 \\
0.7 \\
1.4 \\
2.1 \\
2.5 \\
3.5 \\
5.2 \\
6.9\end{array}$ & $\begin{array}{l}0.21 \\
0.41 \\
0.9 \\
1.51 \\
2.61 \\
3.51 \\
4.41 \\
1.61 \\
8.81\end{array}$ & $\begin{array}{l}0.02 \\
0.04 \\
0.09 \\
0.17 \\
0.26 \\
0.34 \\
0.43 \\
0.65 \\
0.86\end{array}$ & $\begin{array}{l}0.2 \\
0.3 \\
0.7 \\
1.3 \\
2.0 \\
2.7 \\
3.3 \\
5.0 \\
0.6\end{array}$ \\
\hline
\end{tabular}




\section{TABLE VII.-Contimued}

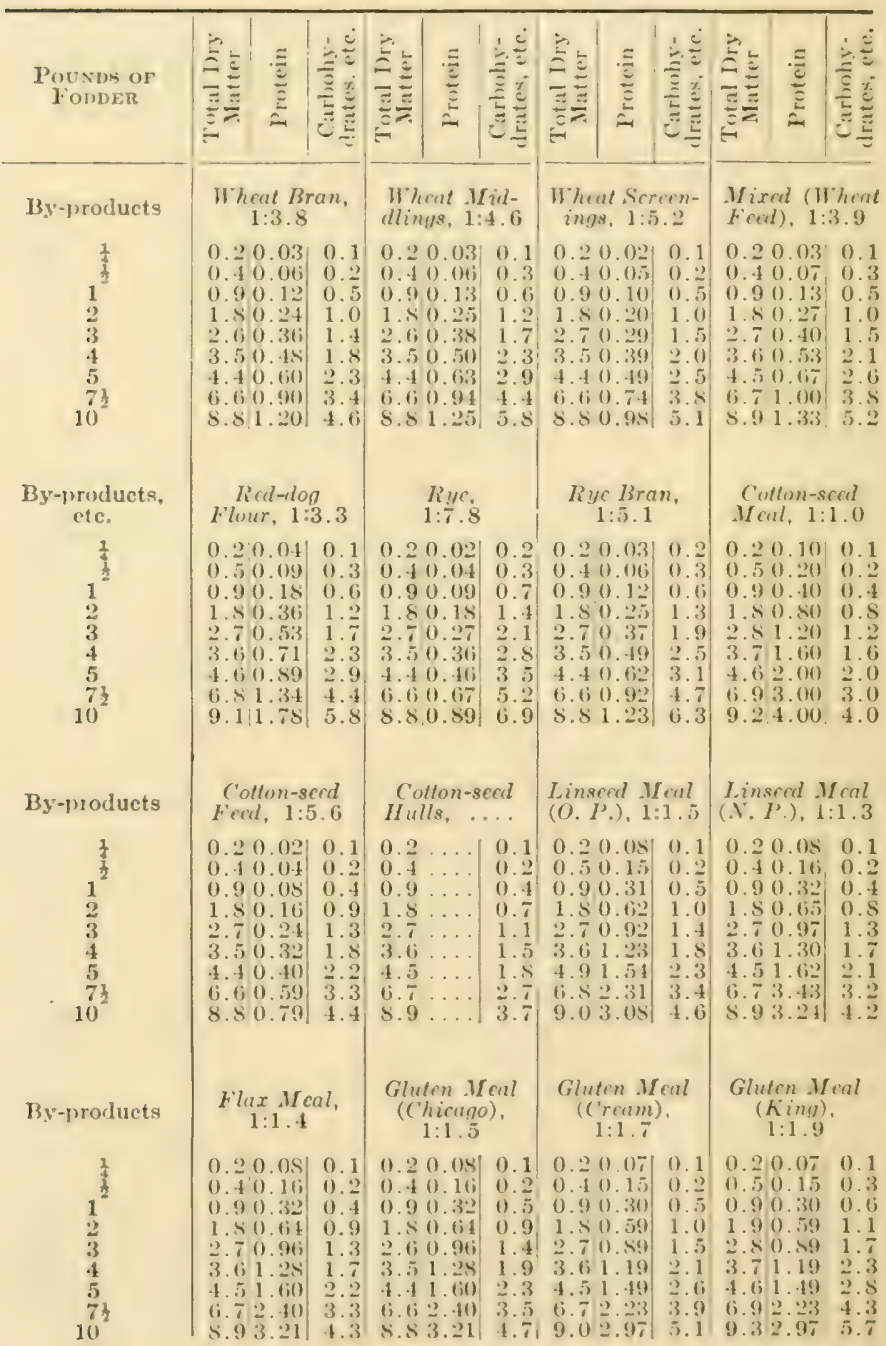




\section{Table VII.-Continued}

\begin{tabular}{|c|c|c|c|c|c|c|c|c|c|c|c|c|}
\hline $\begin{array}{c}\text { Pounds of } \\
\text { FODDER }\end{array}$ & 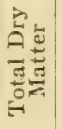 & $\frac{5}{\frac{E}{2}}$ & 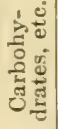 & 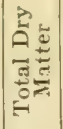 & 这 & 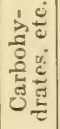 & 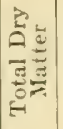 & $\frac{a}{\stackrel{a}{c}}$ & 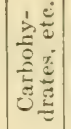 & 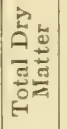 & $\frac{a 1}{\stackrel{0}{0}}$ & 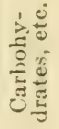 \\
\hline By-products & \multicolumn{3}{|c|}{$\begin{array}{c}\text { Gluten Feed } \\
\text { (Buffalo or } \\
\text { Marshalliown) } \\
1: 2.4\end{array}$} & \multicolumn{3}{|c|}{$\begin{array}{c}\text { Gluten Feed } \\
\text { (Diamond or } \\
\text { liockford), } \\
1: 3.0\end{array}$} & \multicolumn{3}{|c|}{$\begin{array}{l}\text { Ilominy } \\
\text { Chop, } \\
1: 9.2\end{array}$} & \multicolumn{3}{|c|}{$\begin{array}{c}\text { Starch Feed } \\
\text { (wet) } \\
1: 4.9\end{array}$} \\
\hline $\begin{array}{c}1^{\frac{1}{4}} \frac{1}{2} \\
2 \\
3 \\
4 \\
5 \\
70^{\frac{1}{2}} \\
10^{\frac{1}{2}}\end{array}$ & $\begin{array}{l}0.2 \\
0.4 \\
0.9 \\
1.8 \\
2.7 \\
3.6 \\
4.5 \\
6.8 \\
9.0\end{array}$ & $\begin{array}{l}0.06 \\
0.12 \\
0.23 \\
0.47 \\
0.70 \\
0.93 \\
1.17 \\
1.75 \\
2.33\end{array}$ & $\begin{array}{l}0.1 \\
0.3 \\
0.6 \\
1.1 \\
1.7 \\
2.3 \\
2.8 \\
4.3 \\
5.7\end{array}$ & $\begin{array}{l}0.2 \\
0.5 \\
0.9 \\
1.8 \\
2.7 \\
3.6 \\
4.6 \\
6.8 \\
9.1\end{array}$ & $\begin{array}{l}0.05 \\
0.10 \\
0.20 \\
0.41 \\
0.61 \\
0.81 \\
1.02 \\
1.52 \\
2.03\end{array}$ & $\mid \begin{array}{l}0.2 \\
0.3 \\
0.6 \\
1.2 \\
1.9 \\
2.5 \\
3.1 \\
4.7 \\
6.2\end{array}$ & $\mid$\begin{tabular}{l|}
0.2 \\
0.5 \\
0.9 \\
1.8 \\
2.8 \\
3.7 \\
4.6 \\
6.9 \\
9.2
\end{tabular} & $\left\{\begin{array}{l}0.02 \\
0.04 \\
0.09 \\
0.17 \\
0.26 \\
0.35 \\
0.44 \\
0.65 \\
0.87\end{array}\right.$ & $\mid \begin{array}{l}0.2 \\
0.4 \\
0.8 \\
1.6 \\
2.4 \\
3.2 \\
4.0 \\
6.0 \\
8.0\end{array}$ & $\begin{array}{l}0.1 \\
0.2 \\
0.3 \\
0.7 \\
1.0 \\
1.4 \\
1.7 \\
2.6 \\
3.5\end{array}$ & $\begin{array}{l}0.01 \\
0.03 \\
0.05 \\
0.11 \\
0.16 \\
0.23 \\
0.27 \\
0.41 \\
0.54\end{array}$ & \begin{tabular}{|l}
0.1 \\
0.2 \\
0.3 \\
0.5 \\
0.8 \\
1.1 \\
1.3 \\
1.7 \\
2.6
\end{tabular} \\
\hline By-products & Drica & $\begin{array}{l}\text { d Bre } \\
n s, \quad 1\end{array}$ & $\begin{array}{l}\text { wers } \\
: 3.0\end{array}$ & & Glu & $\begin{array}{l}\text { uten } \\
2.6\end{array}$ & Mult & $\begin{array}{l}\text { It Spr } \\
1: 2.2\end{array}$ & its, & & $\begin{array}{l}a \text { Mec } \\
1: 3.2\end{array}$ & al, \\
\hline $\begin{array}{c}1^{\frac{2}{3}} \frac{1}{2} \\
2 \\
3 \\
4 \\
5 \\
7 \frac{1}{2} \\
10^{\frac{1}{2}}\end{array}$ & $\begin{array}{l}0.2 \\
0.5 \\
0.9 \\
1.8 \\
2.8 \\
3.7 \\
4.6 \\
6.9 \\
9.2\end{array}$ & $\begin{array}{l}0.04 \\
0.05 \\
0.16 \\
0.31 \\
0.47 \\
0.63 \\
0.79 \\
1.18 \\
1.57\end{array}$ & $\begin{array}{l}0.1 \\
0.3 \\
0.5 \\
0.9 \\
1.4 \\
1.9 \\
2.4 \\
3.5 \\
4.7\end{array}$ & $\begin{array}{l}0.2 \\
0.5 \\
0.9 \\
1.8 \\
2.8 \\
3.7 \\
4.6 \\
6.9 \\
9.2\end{array}$ & $\begin{array}{l}0.06 \\
0.12 \\
0.25 \\
0.49 \\
0.74 \\
0.98 \\
1.23 \\
1.85 \\
2.46\end{array}$ & $\begin{array}{l}0.2 \\
0.3 \\
0.6 \\
1.3 \\
1.9 \\
2.6 \\
3.2 \\
4.9 \\
6.5\end{array}$ & $\left|\begin{array}{l}0.2 \\
0.4 \\
0.9 \\
1.8 \\
2.7 \\
3.6 \\
4.5 \\
6.7 \\
9.0\end{array}\right|$ & $\mid \begin{array}{l}0.05 \\
0.09 \\
0.19 \\
0.37 \\
0.56 \\
0.74 \\
0.93 \\
1.40 \\
1.86\end{array}$ & $\mid \begin{array}{l}0.1 \\
0.2 \\
0.4 \\
0.8 \\
1.2 \\
1.6 \\
2.0 \\
3.0 \\
4.0\end{array}$ & $\begin{array}{l}0.2 \\
0.4 \\
0.9 \\
1.5 \\
2.7 \\
3.6 \\
4.5 \\
6.7 \\
9.0\end{array}$ & $\left|\begin{array}{l}0.04 \\
0.08 \\
0.17 \\
0.33 \\
0.50 \\
0.67 \\
0.84 \\
1.26 \\
1.68\end{array}\right|$ & $\begin{array}{l}0.1 \\
0.3 \\
0.5 \\
1.1 \\
1.6 \\
2.1 \\
2.7 \\
4.0 \\
5.3\end{array}$ \\
\hline
\end{tabular}

\section{REFERENCES}

(Farmers' Bulletins may be obtained free by application to the Secretary of Agriculture, Washington, D. C.)

\section{Chapter IV}

The World's Worli, August, 1906, p. 7ssi), "Desert Farming Without Irrigation."

The World To-day, August, 1906, p. S62, "Farming Without Water." 


\section{Chapter V}

Farmeres Bulletins: No. 192, Barnyerd Manures; No. 245, Renovation of Worn-out Soils.

\section{Chapter VIII}

Farmers' Bulletins: No. 2s, Weeds and How to Kill Them; No. 27, C'anadu Thistle, ('irculatr 27, Division of Botany; No. 132, The Insect Enemies of Groving theat; No. 3s, sipratying Fruit; No. 6, Bordeaux Mixtures, I Division of Veqietam.e PathonderiY; No. 2-47, The Control of the Coolling Moth and Apple Scab; No. 19, Important Insecticides.

Aply to the Agrieultural Experiment station, Madison, Wis., for the following Farmers' Bulletins: No. 111, The Preventien of the Out smut; No. 1355, The sipraying of Potates:s.

\section{Chapter X}

Farmers' Bulletins: No. 15i, The Propatution of Plants; No. 229, The Production of Good Seed Corn.

\section{Chapter XII}

Ciet seedmen's catalogues and read and study the directions.

Farmers' Bulletins: No. 61, Aspreragus ('ulture; No. 15t, The Home Frmit Ciarden; No. 9.4, The legetahle ciarden; No. 198, Stranberries; No. 220, Tomatoes; No. 254, cucumbers.

\section{Chapter XIII}

Farmers' Bulletins: Noo. 25, Pcomuts; No. 35, Potato Culture; No. 47, Insects Affecting (otton; No. 52, The singur But; No. S1, C'om C'ulture in the south; No. 91, Potuto Diseases;

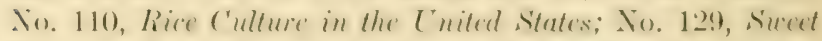
Potatoe: No. 132, Insect Einemies of (irouring Wherat; No. 199, Corn Growing. 


\section{Chapter XIV}

Farmers' Bulletins: No. 113, The Apple and How to Grow It; No. 33, Peach Grouing for Warket; No. 62, Marlicting Farm Produce; No. 80, The Peach-Twig Borer; No. 175, Home Manufacture and Use of Unfermented Grape Juice; No. 20:3, Canned Fruits, Preserves, and Jellies.

\section{Chapter XV}

Farmers' Bulletins: No. 143, Conformation of Bef and Dairy Cattle; No. 106, Breeds of Dairy Cattle.

\section{Chapter XVIII}

Farmers' Bulletins: No. 96, Raising sheep for Mutton; Xo. 104, Food Requirements of Pigs, Agrieultural Experiment sitition, Madison, Wis. Study them and try to make some experiment suggested by these Bulletins on feeding sherp and pigs.

\section{Chapter XIX}

Farmers' Bulletins: No. 51, Standard Varicties of ('hickiche; No. 64, Ducks and Gicese; No. 1s2, Poultry as Fond; No. 200, Turlicys: Standard Vuricties and Manayement; Xo. 2S7, Poultry Management; also Watson's Furm Poultry, Maemillan Co.; Comstock's How to Keep Bees, Inoubleday, Page \& Co.

\section{Chapter XX}

Farmers' Bulletins: No. 96, Raising sheep for Mutton; No. 100, Hog Raising in the South; No. 142, Principles of Nutrition and Nutritive Value of Food; No. 151, Denirging in the South; No. 170, Principles of Horse Feeding. 



\section{N D E X}

Aberdeen-Angus cattle, 166. Absorption of water by soil, experiment, 24.

Agriculture, defined, 1.

Air, experiment to show necessity for plant growth, 8 ; increased in soil by underdrainage, 26; in soil, 23; made up of oxygen and nitrogen, 63 .

Alfalfa, 54, 134; several crops, 69.

Amendments, defined, 49.

Animals, 69-72; care of, 223.

Annato, for coloring butter, 178.

Apples, 150; Baldwin, to produce, 124.

Ashes, 49; wood, for apple orchard, 151.

Asparagus, in garden, 131.

Babcock milk test, 174 .

Bacteria, 43 ; cause of plant disease, 85 ; in roots of legumes, 55 .

Balanced ration example, 219.

Barnyard manure. See MANURE. Baswood, for planting, 235.

Bean, Burpee, 113; in garden, 130.
Bees, 209.

Beets, in garden, 129; sugar in, 115.

Berkshire swine, 196.

Biennials, 69, 72 .

Birds and their food, 90; attracting, 96; feeding, 98; houses, 96 ; number of, 90 ; useful, 74 .

Blight, Bordeaux mixture for, 243 ; peas, 153.

Bluebird, 92.

Bordeaux mixture, \$4, \$6, 243.

Brahma chickens, 206.

Bronco, 188.

Budding, 125.

Buds, 3; growth from, 117.

Bulbs, defined, 235.

Burbank, Luther, 108.

Butter, 177.

Cabbage worm, 81 .

Calcium earbonate, 51.

Calories, defined, 218.

Cambium layer, 123.

Canada thistle, a perennial, 72 .

Canker worm, $\$ 1$.

Capillarity, 21.

Capillary attraction, 25.

Carbon, defined, 64. 
Carbonic acid, in soil water, 6 . Carbon dioxide, composition of, 6.t; absorbed by leaves, 7; used to make starch, 64 .

Carbohydrates, in various foods, 250-25t; use in feed, 216.

Care of animals, 223.

Carrots, 143.

('asein, in cheese, 179; in milk, 170.

Casterilius, picture of, 161.

Caterpillar, stung by ichneumon fly, 100.

Cats, enemies of birds, 99.

Cattle, chapter on, 159 ; advantages in raising, 166; beef breeds, 164; importance of good, 167.

Celery, in garden, 131.

Chalcis fly, 100.

Chalk, an amendment, 50.

Cheese, 178.

Cherries, 154.

Cheshire swine, 196.

Chester white swine, 195.

Cheviot sheep, 194.

Chicken, breeds of, 20t; coop, $26 \mathrm{~s}$.

Chinch bug, described, 83.

G.hurn, 178.

Clay, 12.

Clover, 54; crimson, 135; roots showing nodules, 55 .

Clovers, 135.

Clydesdale horses, 187.

Cochin chickens, Buff, 206.

Codling moth, so.

Colostrum, 171, 172.

Composition of foods, table, 68. Compounds, defined, 40 .
Corn, 135; composition of, 216 ; effect on soil, 59 ; sweet, in garden, 130.

Cotswold sheep, 194.

Cotton, 143.

Cow, dairy, 159; usefulness of, 159.

Cream, 176.

Cucumbers, in garden, 130.

Cuttings, 117, 120.

Dairy farm, rotation for, 61 .

Dan Patch, 184.

Danzenbaker hive, 211.

Delaine sheep, 192.

Diseases. See plant diseases.

Dorset IIorn sheep, 193.

Dragonflies, 101.

Drainage, methods of, 27.

Dry farming, 37.

Dry matter, in various foods, 250.

Ducks, geese, and turkeys, 207.

Duroc Jersey swine, 196.

Elements, 40.

Elm, American white for planting, 235.

English Shire horse, 186.

Ensilage, 220.

Essex swine, 197.

Evaporation, 20; carries away heat, 23.

Factory, of nature, 63.

Farmer, work of, 1; knowledge required, 1, 2.

Farmer's friends, ehapter on, 90.

Fat, in various foods, 250, 254; use in feed, 216. 
Feeding stuffs, kinds of, 220; table of, 250.

Feeds, classes of, 216.

Feeds and fodders, constituents of, table, 254.

Feldspar, 12; source of potassium, 41.

Fermentation, in tobacco, 149.

Fertility removed by crops, 246.

Fertilizers, commercial, with root crops, 143; for hay, 133; licensed, 48; commercial, 48 .

Finches, 95.

Fire blight, 85 .

Flowers, 103; part of, 103; use of, 4 .

Flower garden, 237.

Food, digestible ingredients, table, 250, 254; for birds, 97.

Food, animal, importance of, 214.

Food elements, how the plant combines, 66.

Forest, how it may be perpetuated, 233; some advantages of, 230 .

Forestry, the purpose of, 229; what other nations are doing, 231; what our government is doing, 232.

Formaldehyde solution for oats, 244.

Frogs, 99.

Fruit, marketing, 154.

Fuel value, 252; in various foods, 250.

Fungicides, 88.

Garden, care of, 128; desirable plants for, 12S; farm impor- tance of, 127; farm, chapter on, 128; flower, 237 ; position and soil for, 127.

Germination, conditions affecting, 116.

Glaciers, action of, in soil formation, 16.

Gluten, to prepare, 66.

Good roads, forestry, home and school grounds, chapter on, 226.

Good roads, farmer's interest in, 226; how to make and keep, 226.

Grafting, 117, 121; necessity for, 124.

Grafting wax, formula, 123.

Granite, 12, 13.

Grapes, 154.

Growth, conditions of, 7 .

Guano, source of phosphate, 41.

Guernsey cattle, 161.

Gypsum, an amendment, 50.

Hackney horses, 187.

Hambletonian horses, 184.

Hampshire sheep, 193.

Hampshire swine, 197.

Harrows, 36.

Hay and grass crop, 133.

Hay, curing, 134; for horses, 133. Heat, production by plant, 68 . Herd, how to improve; 167.

Hereford cattle, 166; cow, picture of, 165.

Hodge, Prof., report on honey 211.

IIolstein cattle, 160.

IIome and school grounds, 234. Houdan chickens, 204. 
Horse, chapter on, 1S1; antecedents and types, 181; desirable charaeteristics, 181; external parts of, 182; for speed, 183; coach, 187; draft, 185; intelligence of, 189; rations fed to, table, 253 ; use and care of, 158.

Humus, defined, 11; holds water, 26.

Hybrids, 107.

Hyirogen, defined, 64.

Ichneumon fly, 99.

India, forestry in, 232.

Indian corn. See corn.

Inoculation, to supply bacteria, 56.

Insects, classified, 79; common cutting, 80 ; deseription, 77; life history, 78; scale San José, S3; control, 84; useful, 99.

Iron sulphate, for killing weeds, 97.

Jersey cattle, 162.

Johanna, Colantha Fourth's, picture and record, 160.

Justin Morgan, 185.

Kerosene emulsion formula, 245. Killdeer, 95.

Lactic acid, in milk, 172.

Langshan chickens, 206.

Langstroth hive, 211.

Larvie, in soil, 57.

Layering, 117, 121.
Leaves, use of, 3.

Leghorn chickens, 204.

Legumes, 5t; as deep feeders, 56 ; as forage, 57 ; as nitrogen gatherers, 55.

Leguminous plants, chapter on, 54.

Icicester sheep, 194.

Lettuce, in garden, 129.

Lichens, 16.

Light, essential to growth, 7 , experiment to show need of, 7 .

Lime, an amendment, 49; as an aid to nitrification, 50; phosphate of, 41.

Limestone, 12; weathering, 13.

Lincoln sheep, 194.

Loam, defined, 11.

Locust tree, a legume, 54.

London purple, $\$ \$$.

Mambrino Chief, 184.

Manure, barnyard, 46; care of, 47; value of from horse, ete., 47 .

Marl, an amendment, 50.

Massachusetts, rotation in, 61 .

Meadow lark, 95.

Merino sheep, 192.

Messenger, Imported, 183.

Metamorphosis, explained, 78 .

Mica, 12.

Mildew, 87.

Milk, Babcock test outfit, 175; composition of, 170; food value of, 172 ; pails, 173; separator, 174; skimmed, 177; tester, 174; souring of, 172. 
Milk and its products, chapter on, 170 .

Milk of different breeds of cattle, 171.

Minor Heir, 184.

Moisture, how the soil may hold more, 25 ; regulation of, 32 . Morgan horses, 185.

Mosses, 16.

Muck, an amendment, 50.

Mulch, surface, defined, 32 .

Mlushrooms, 2.

Nest building, materials for, 97 .

Nitrate, defined, 41.

Nitrification, defined, 50.

Nitrogen, defined, 40 ; effect on plant, 46 ; in manure. 46 ; fixation with legumes, 55; removed by crops, 60; source of, 43; with barley, 138.

Norfolk system of rotation, 60 .

Nuthatches, 95.

Nutrients, table of, for day's feeding, 248.

Nutritive ratio, defined, 217; how found, 249.

Oats, a farm crop, 137; smutty, illustration, 86 ; to prevent smut in, 244.

Ohio, rotation in, 61 .

Oil, made in plants, 63; where found, 65 .

Oriole, Baltimore, 95.

Osmosis, 43; experiment, 44.

Oxford sheep, 194.

Oxygen, 63.
Pandora, Lady, picture of, 163.

Paris green, S4; formula, 245.

Peaches, 153.

Peanut, a legume, 54 .

Pears, 152.

Peas, field, 141; in garden, 129.

Percheron horses, 186.

Perennials, hardy, 239; for farmer's flower garden, 239.

Phosphoric acid, in ashes, 49; removed by crops, table, 60; with barley, 138.

Phosphorus, defined, 41; effect on plants, 46.

Phylloxera, grape, 83.

Plankers, 36.

Plant, decayed, help make soil, 11; how it grows, 4; parts of, 2; the nature of, chapter on, 1.

Plant diseases, common and treatment, 85 ; nature of, 85.

Plant enemies, chapter on, 71 .

Plant food, chapter on, 63; dissolved in water, 6 ; from air, 7 ; how it gets into the plant, 43; locked up, 9; must be usable, 8 ; source of, 42; stored in seed, 5 ; use of each kind, 45.

Plant lice, 83.

Plover, 95.

Plow, described, 35.

Plowing, successful, 35

Plum, Kelsey, 108; Wickson, 108.

Plumeot, 108.

Plymouth Rock chickens, 206.

Poland-China swine, 195. 
Polled Durham cattle, 166.

Pollination, 106; cross, 107.

Ponies, 187.

Pony, Northern Indian, 1Ss; Shetland, 187.

Porosity of soil, 21.

Potash, 42; amount in wheat, 45; experiment to obtain, 42; in ashes, 49 ; in manure, 46 ; muriate of, 134 ; removed by crops, table, 60.

Potassium, defined, 41.

Potato beetle, 82 ; blight, 88 ; scab in soil, 57 ; scab, SS.

Potatoes, 141; grown from cuttings, 121; scabby, how to treat, 245.

Poultry and bees, chapter on, 202.

Poultry, raising and care of, 207; benefits of, 202.

Products of plant growth, 64 .

P'rofit and loss in feeding, 222.

Propagation, of plants, 10S; other than by seed, 119.

Proteid, deseribed, 65; made by plants, 63.

Protein, described, 65; in various foods, 250, 254; use in feed, 216.

Protoplasm, 44.

Pruning, 15t, 156.

I'ulse family, 54 .

Quartz, 12.

Radishes, in garden, 129.

Rainfall, amount necessary for crops, 37.

Rambouillet sheep, 192.
Ration, balanced, 217; for horse, example of, 221; actually fed to horses, table, 253.

References, 259.

Rena Ross, picture of, 164.

Rice, 146.

Robin, 91.

Rocks, decayed, helps make soil, 10.

Rollers, 36.

Roots, 2; open up soil, 26.

Root crops, 142.

Root hairs, 3 ; absorb water, 6 . take nitric acid, 41.

Rotation of crops, chapter on, 54; defined, 57; destroys weeds, 58; enlarges farm, 58 ; regulates food supply, 59 ; a weapon against pests, 57; Norfolk system, 60.

Rust, wheat, 85 .

Salt, common, an amendment, 50.

Saltpeter, source of potassium, 41.

Salts, mineral, 6.

Sandstone, 12.

San José scale, 83.

Scab, in potatoes, 141.

School and home grounds, 234.

Scion, 121; for grafting, 150.

Seeds, 103; age of viable, 109; table, 110; description, 5; maturity of, 110 ; production, 69; quality of, 109 ; selecting, 110; space and quantity required, 247 ; testing, 115 ; use of, 4 .

Seed bed, preparation of, 32 . 
Sheep, breeds of, 191.

Sheep and swine, chapter on, 191.

Sheep raising, advantages of, 191.

Shells, contain phosphate, 41.

Shorthorn cattle, 166.

Shrophsire sheep, 193.

Shrubs, hardy flowering, 239.

Silo, 220.

Smut, corn, 85; oat, 86 .

Soil, chapter on, 10; constituents in average crop, 246; defined, 10; enriching, chapter on, 48; formation of, 13; good farm, 18; kinds of, 11; porosity, 21; uses of, to plants, 17.

Soil enriching, chapter on, 40.

Southdown sheep, 193.

Sparrow, 95.

Sporges of fungi, etc., 85.

Spraying, potatoes, 141.

Spruce, Colorado blue, for planting, 235.

Stable, filthy, illustration, 224.

Starch, changing to sugar, 66 ; changed to sugar, 67 ; described, 64; made in plants, 63 ; stored-up, 66, 67; test for, 64 .

Stems, 3.

Straw, burning, 45.

Strawberries in garden, 131.

Subsoil, 10.

Sugar, 65; amount in beets, 115 ; changed to starch, 67 ; made in plants, 63 .

Sugar cane, 145.

Swarming of bees, 210.
Swine, advantage of raising, 194; breeds of, 195; where and how to raise, 198.

Switzerland, forestry in, 231.

Tamworth swine, 197.

Tanager, scarlet, 92.

Thoroughbred horses, 183.

Thrushes, 92.

Tillage, for two reasons, 33; implements of, 34 ; importance of good, 34; object of, 30 ; to cover manure, 33 .

Tiles for drainage, 27.

Tilling, a risk in, 33 .

Tilling the soil, chapter on, 30 .

Toads and frogs, 99.

Tobacco, 146; effect on soil, 59.

Tools, care of, 36 .

Topping, tobaceo, 147.

Transplanting, 154.

Trees and shrubs, 234 .

Tubercules on legumes, 55; on roots, 43.

Tull, Jethro, 34 .

Turnips, 143; in rotation, 60 .

Underdrainage, benefits of, 26 .

United States, rotation in, 60.

Victoria swine, 197.

Vines, 236.

Water, amount used by different plants, 22; effect of too little in the soil, 22 ; effect of too much, 22; freezing breaks rocks, 13; importance of, to plant, 20; movement of, in the soil, 20 ; in soil, 7. 
Water in the soil, chapter on, 20. Water on surface of soil partieles, 25.

Weather, effect on rocks, 14.

Weathering, 13; agent, 16.

Weeds, annual, how to kill, 72; biennial, how to kill, 75; classes of, 61 ; defined, 71; perennial, how to kill, 75 ; to kill, 33; why enemies, 71.

Wheat, extensive root system, 58 ; Fultz, produced by selection, 113; macaroni, 37; wheat and other grains, 137.
IVhey, 179.

Winter wheat, 59.

Wind, effect on rocks, 15.

Wolf-Lehmann, standard table, 248.

Woodpeckers, 93.

Wood tissue, 65.

Wrens, 96.

Wyandotte chickens, 206.

Yeksa Sunbeam, feed of, during test, 216; picture of, 162.

Yorkshire swine, 197. 




\section{THE APPLETON ARITHMETICS}

TW0=B00K SERIES

\section{Primary Book $=$ = Cloth, $35 \mathrm{c}$}

$55 \mathrm{c}$

\section{THREE-B00K SERIES}

Primary Book = = Cloth, $35 \mathrm{c}$ Second Book = " " $40 \mathrm{c}$ Third Book - " "40c

The fundamental principles taken as guides in the preparation of this series are: (I) Interest is the corner-stone of all successful teaching; (2) The child's play leads to self-revelation; (3) Manual expression is necessary to clear ideas; (4) No education is complete that ignores the industrial side; (5) No subject stands alone in the school curriculum.

The plan of the books is exceedingly simple. The oral work is separated from the written, the abstract from the concrete, and the whole is well balanced and carefully graded. The natural activity of the child is utilized by the abundant opportunities for experimental work, and his interest is held by the diversity of topics from which the problems are drawn. The problems cover a broad field, including geography, nature studies, manul training, domestic art, and the forms of modern business practice. The teacher will appreciate the frequent reviews, by topic and chapter. Sufficient algebra is presented to prepare the pupil for the high-school course.

\section{THE APPLETON ARITHMETICS}

(I) Present the essentials of arithmetic systematically.

(2) Drill on the essentials of arithmetic thoroughly.

(3) Apply the essentials broadly.

(4) Embody the whole artistically.

D. A P PLETONAND COMPA N Y NEW YORK

CHICAGO 


\section{AN ELEMENTARY UNITED STATES HISTORY}

\section{Builders of Our Country}

By Gertrude Van Duyn Southworth, Author of "The Story of the Empire State," "A First Book in American History," etc. Two volumes. Fully illustrated. $12 \mathrm{mo}$. Cloth, 60 cents each. Volumes sold separately.

These two books, telling the stories of more than fifty of the most important characters in United States History, from the year rooo to the present time, form a splendid equipment for the teaching of elementary history in the Fifth and Sixth Grades.

Nothing makes History so real to the pupil of ten or twelve as biographical studies in which historical events are so portrayed by striking and vivid pictures as to become firmly fixed in the memory. The pupil thus becomes familiar in the most interesting way with the chief events of our national life-a knowledge invaluable further on in the more formal study of History.

The author, in her concise and charming style, has succeeded in drawing just such vivid pictures of the men and times, recounting personal incidents of interest, while adhering strictly to the requirements of an authentic historical record. A special point is the continuity of the story throughout the books, despite the biographical plan of presentation.

Profuse illustrations serve to throw light upon the text and give an accurate idea of the life of the various periods. Each book is made complete by review questions covering each chapter, a chronology, and a pronouncing index.

D. A P PLETON A N D COMPA N Y NEW YORK CHICAGO 


\section{THE KROHN PHYSIOLOGIES.}

BY WILLIAM O. KROHN, M.D., PH.D.

\section{A First Book in Physiology and $\mathrm{Hy}$ - giene. Illustrated. 152 pages. Cloth, 35 cents.}

A series of bright, simple lessons for littie children, with the emphasis on hygient. It explains a few jmportant things in a very clear and attractive wav, bringing in pictures, verses, and legends to drive each lesson home. Everything that the children learn is put to test in useful exercises, each as good as a game, many of them calling for individual observation and reasoning. It is just the book to rouse a child's initiative and make him choose for himself the road to health.

I believe you have struck the key-note for teaching hygiene to little people. -ADA VAN. STONE HARRIS, Supervisor of hindergarten and Primury Schools, Rochester, $N$. $Y$.

It is a gem from title to finish.-WM. J. Cox, Superintendent of Public Schools, Moline, Ill.

I have the little volume, and it is the only one in my experience where the study of the human body and its needs is not made repulsive and tiresome. The book is so cheery, it is like any other interesting story.-FANNIE MCGEE, Public Schools, Kansas City, Mo.

\section{Graded Lessons in Physiology and $\mathrm{Hy}$ - giene. Illustrated. 294 pages. Cloth, 60 cents.}

An advanced book, thoroughly scientific and thoroughly practical. Func. tion is treated more fully than structure, but the most common and important matters of anatomy and physiology are explained clearly and accurately. The whole book pleads for health-for strong will power and good habits as a first requisite to good citizenship. This broad, wholesome view of the subject includes chapters on public sanitation and on diseases growing out of the specialization and stress of modern life. The book illustrates concretely and forcibly the far-reaching importance of the whole subject, and sets exercises and questions for discussion. It has a convenient pronouncing glossary.

Both teachers and pupils are more than satisfied with these books. In fact, the "Lessons in Hygiene" has become to them a matter of delight. The text has stimulated many of our children to independent observation. $-I^{\circ}$. N. Hallmann, Formerly Superintendent of Instruction, Dayton, Ohio.

A most practical and up-to-date text-book. It combines science and good sense in happy degrees.-W. M. BEARISIIEAR, Late President State College, Ames, Jowa.

It is a great contribution, as touching the every-day life of the clild, upon a great subject.-Charles H. Alizert, State Normal School, blowmsburg, $\mathrm{Pa}$.

I regard it the best book on elementary hygiene that I have ever seen.JoIn R. KIRK, President State Normal School, K'̈rkszille', Mn.

D. APPLETON ANI) COM PANY, NEW YORK.




\section{NATURE STUDY AND AGRICULTURE}

\section{Practical Nature Study and Elementary Agriculture}

A Manual for the Use of Teachers and Normal Students. By John M. Coulter, Director of the Department of Botany, University of Chicago; John G. Coulter, Professor of Biology, Illinois State Normal University; Alice Jean Patterson, Department of Biology, in charge of Nature Study, Illinois State Normal University. I $2 \mathrm{mo}$, cloth, \$I. 35 net.

This book is an attempt, on very practical lines, to help the teacher of nature study to become more independent in his work, and to make his work more definite. The volume has grown out of the experience of the authors. The material has largely been used in regular class work, and found efficient under conditions similar to those of the average school.

Part I is devoted to presenting the principles of nature study, its mission and spirit, as well as the dangers which the study entails and how to avoid them. It is practically a guide to the teaching of nature study. Part II contains a detailed topical outline by grades and seasons of the materials used in nature study in the training school at the Illinois State Normal University. Its definite outlines of work will be of important service to teachers who are called upon to handle the subject with slight previous training. Part III is principally devoted to an outline course for elementary agriculture in the seventh and eighth grades, with most of the lessons worked out in detail. These lessons have all satisfactorily met the test of class-room use. Part IV comprises certain chapters on more general topics-material which will prove serviceable for teachers whose general science training has been slight or is lacking entirely. The aim is to provide a scientific point of view of the materials ard principles which are to be used in the work.

The study of this exceedingly practical book, the aim of which is to aid in making nature study practical under present teaching conditions, should produce better teachers and more enlightened students.

\section{A P PLETON A N D COM P A N Y NEW YORK


APR is 1910 
One copy del. to Cat. Div.

\author{
APG II 299
}




\section{LIBRARY OF CONGRESS

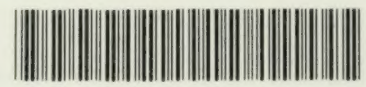

00025863951 